\title{
The Revolution of Everyday Life
}

\author{
Raoul Vaneigem
}

1963-1965 


\section{Contents}

$\begin{array}{lr}\text { Dedication } & 6\end{array}$

Author's Preface to the First French Paperback Edition 7

The Everyday Eternity of Life . . . . . . . . . . . . . . . . . . . . 7

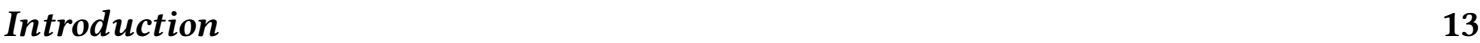

$\begin{array}{ll}\text { Part I. The Perspective of Power } & 15\end{array}$

Chapter 1. The Insignificant Signified 16

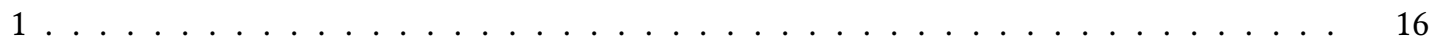

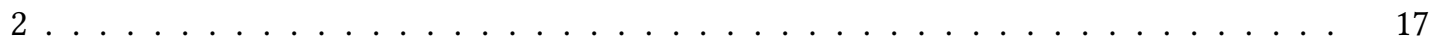

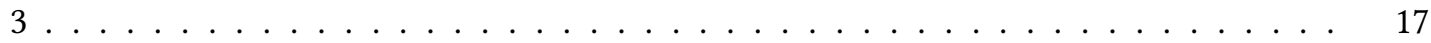

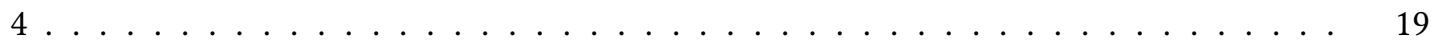

Impossible Participation or Power As the Sum of Constraints 20

Chapter 2. Humiliation $\quad 22$

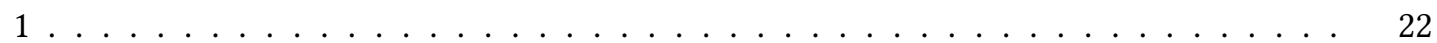

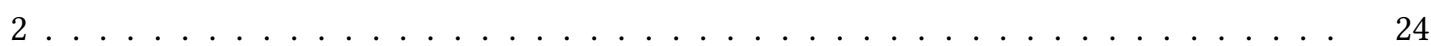

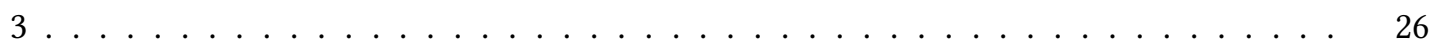

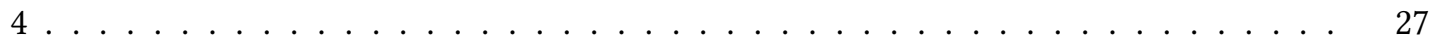

Chapter 3. Isolation $\quad 28$

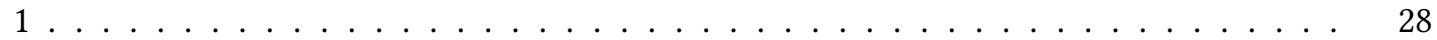

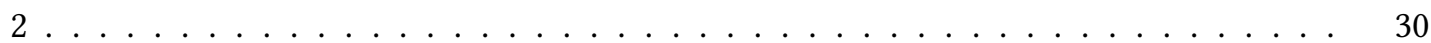

Chapter 4. Suffering $\quad 32$

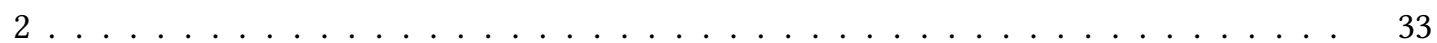

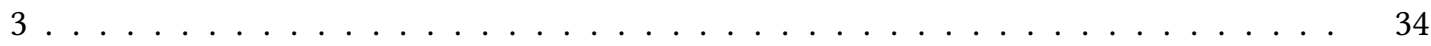

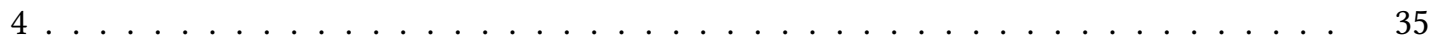

$\begin{array}{ll}\text { Chapter 5. The Decline and Fall of Work } & 37\end{array}$

Chapter 6. Decompression and the Third Force 40 
Chapter 7. The Age of Happiness $\quad 46$

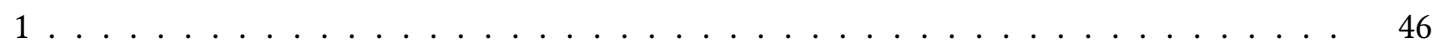

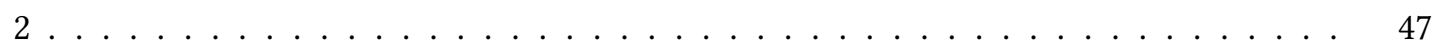

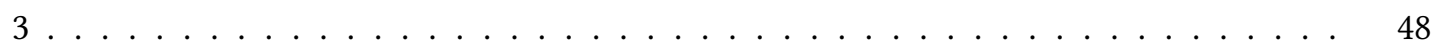

Chapter 8. Exchange and Gift 51

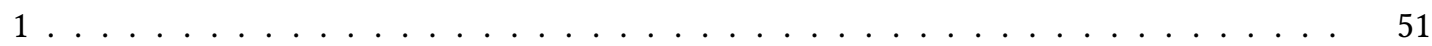

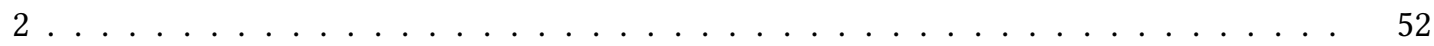

Chapter 9. Technology and Its Mediated Use 56

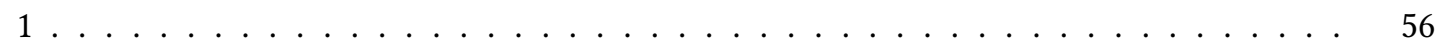

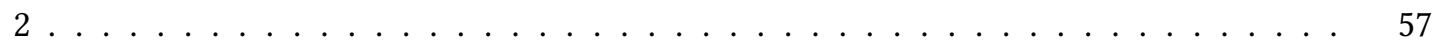

Chapter 10. Down Quantity Street $\quad 60$

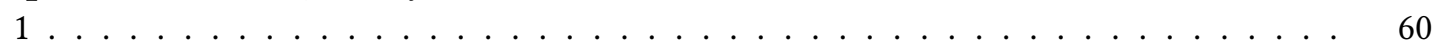

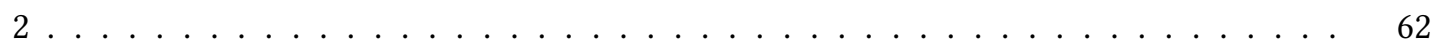

Chapter 11. Mediated Abstraction and Abstract Mediation $\quad 64$

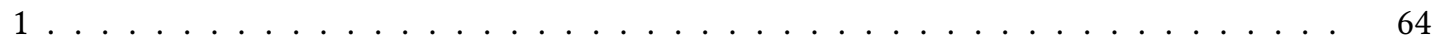

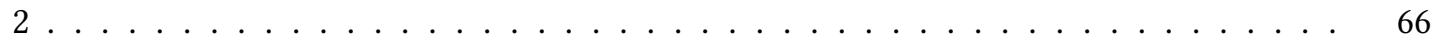

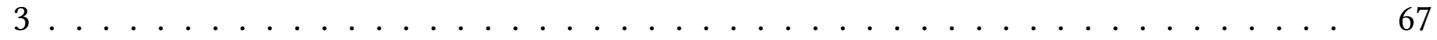

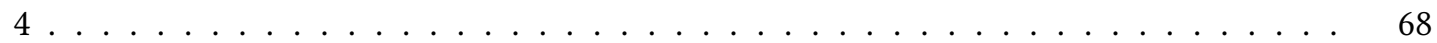

Impossible Realisation or Power As the Sum of Seductions 72

$\begin{array}{ll}\text { Chapter 12. Sacrifice } & \mathbf{7 4}\end{array}$

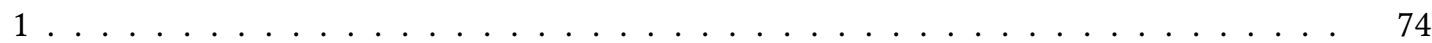

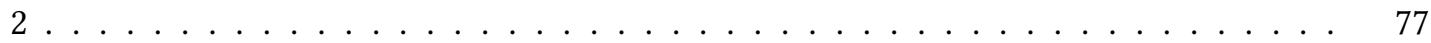

$\begin{array}{lr}\text { Chapter 13. Separation } & 81\end{array}$

Chapter 14. The Organization of Appearances $\quad 85$

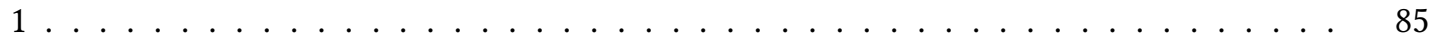

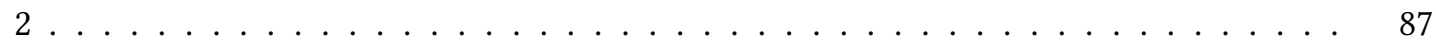

Chapter 15. Roles $\quad 90$

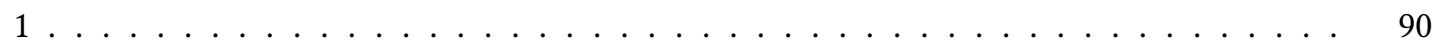

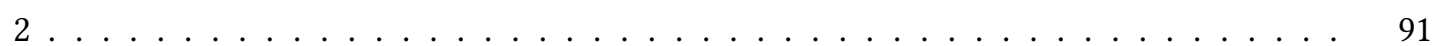

3 Identification . . . . . . . . . . . . . . . . . . . . . . 93

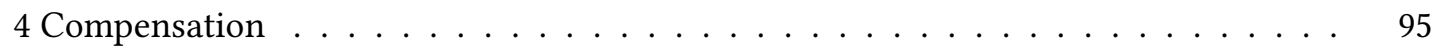

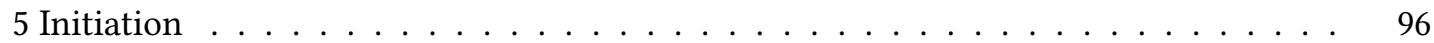

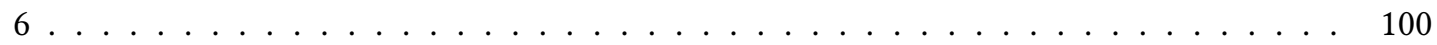

$\begin{array}{ll}\text { Chapter 16. The Fascination of Time } & 103\end{array}$ 
Survival and False Opposition to It $\quad 106$

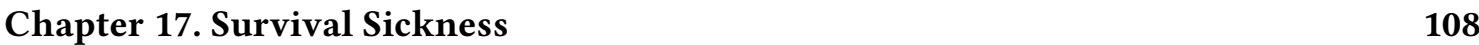

Chapter 18. Spurious Opposition 111

1 The Question of Transcendence . . . . . . . . . . . . . . . . . . . . 111

2 The Renunciation of Poverty and the Poverty of Renunciation . . . . . . . . . . . 113

3 The Individual of Ressentiment . . . . . . . . . . . . . . . . . . . . . . . . 117

4 The Nihilist . . . . . . . . . . . . . . . . . . . . . . . . . . . . . . . . 119

Part II. The Reversal of Perspective $\quad 124$

$\begin{array}{ll}\text { Chapter 19. The Reversal of Perspective } & 125\end{array}$

Chapter 20. Creativity, Spontaneity, and Poetry 128

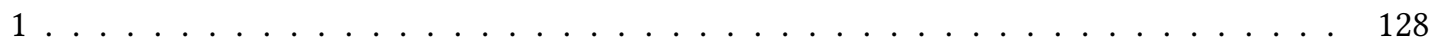

2 Spontaneity . . . . . . . . . . . . . . . . . . . . . 130

3 The Qualitative . . . . . . . . . . . . . . . . . . . . . . . . 132

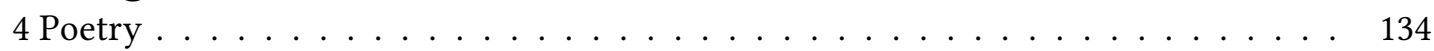

$\begin{array}{lr}\text { Chapter 21. Masters Without Slaves } & 137\end{array}$

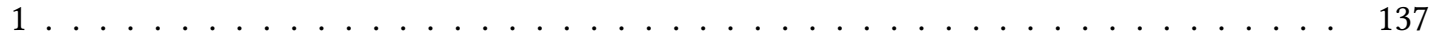

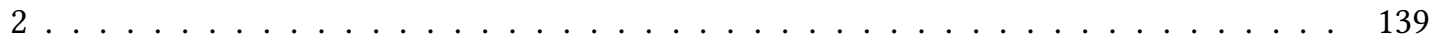

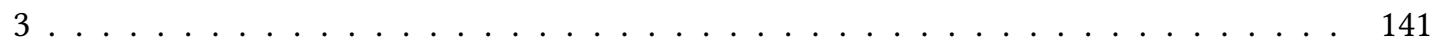

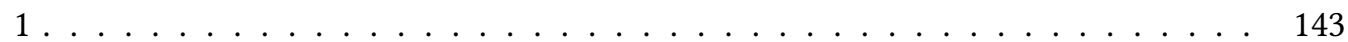

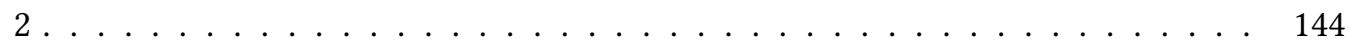

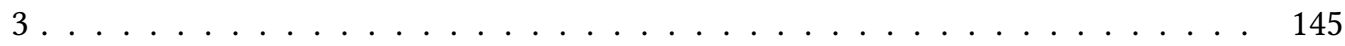

Chapter 22. The Space-Time of Lived Experience and the Rectification of the Past 147

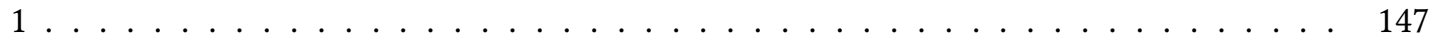

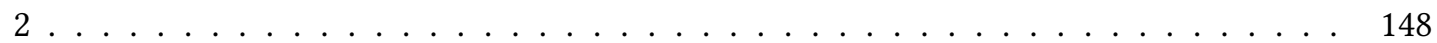

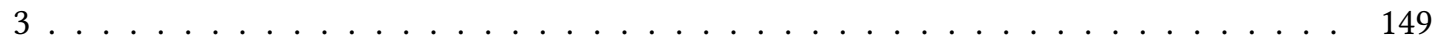

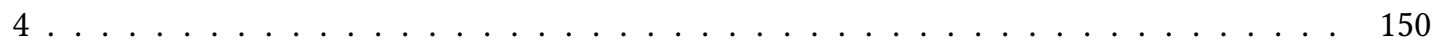

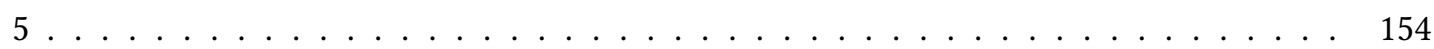

Chapter 23. The Unitary Triad: Self-Rrealisation, Communication and Participation 157

$1 \ldots \ldots \ldots \ldots \ldots \ldots \ldots \ldots$

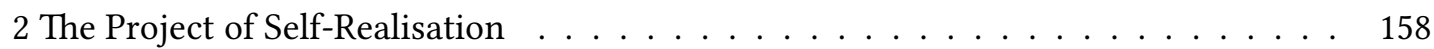

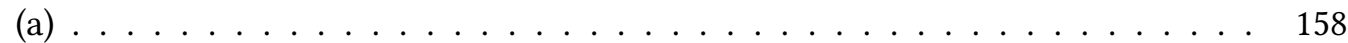

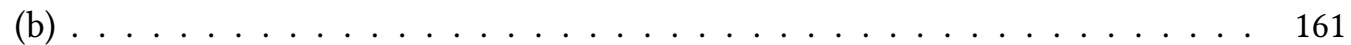

3 Radical Subjectivity . . . . . . . . . . . . . . . . . . . . . . . . . . . . . . 162

4 The Project of Communication . . . . . . . . . . . . . . . . . . . 164

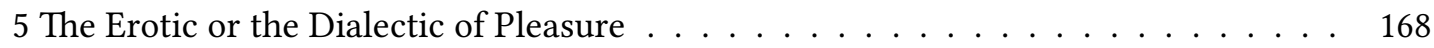

6 The Project of Participation . . . . . . . . . . . . . . . . . . 170

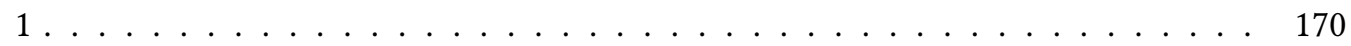




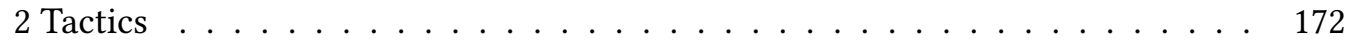

3 Diversion . . . . . . . . . . . . . . . . . . . . 175

Chapter 24. The Interworld and the New Innocence 177

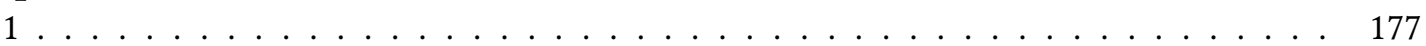

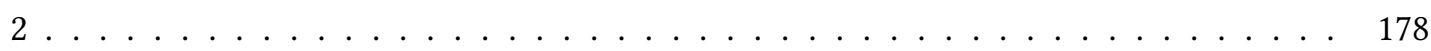

Chapter 25. You're Fucking Around with Us? - Not for Long! 180

A Toast to Revolutionary Workers 182 


\section{Dedication}

To Ella, Maldoror and those who helped this adventure upon its way. "I LIVE ON THE EDGE OF THE UNIVERSE AND I DON'T NEED TO FEEL SECURE."

"Man walketh in a vain shew, he shews to be a man, and that's all."

We seem to live in the State of variety, wherein we are not truly living but only in appearance: in Unity is our life: in one we are, from one divided, we are no longer.

While we perambulate variety, we walk but as so many Ghosts or Shadows in it, that it self being but the Umbrage of the Unity.

The world travels perpetually, and every one is swollen full big with particularity of interest; thus travelling together in pain, and groaning under enmity: labouring to bring forth some one thing, some another, and all bring forth nothing but wind and confusion.

Consider, is there not in the best of you a body of death? Is not the root of rebellion planted in your natures? Is there not also a time for this wicked one to be revealed?

You little think, and less know, how soon the cup of fury may be put into your hands: my self, with many others, have been made stark drunk with that wine of wrath, the dregs whereof (for ought I know) may fall to your share suddenly."

From: "Heights in Depths and Depths in Heights (or TRVTH no less secretly than sweetly sparkling out its Glory from under a cloud of Obloquie)" by the Ranter Jo. Salmon (1651). 


\section{Author's Preface to the First French Paperback Edition $^{1}$}

\section{The Everyday Eternity of Life}

The Traité de savoir-vivre à l'usage des jeunes générations heralded the emergence of a radically new era from the bosom of a waning world.

With the quickening of the current that has for a short while now been carrying beings and things along, the Traité has grown, so to speak, ever more clairvoyant.

The stratified past still clung to by those who grow old with time is ever more easy to distinguish from the alluvia, timeless in their fertility, left by others who awake to themselves (or at least strive to) every day.

For me, these are two moments of a single fluctuating existence in which the present is continually divesting itself of its old forms.

A book that seeks to interpret its time can do no more than bear witness to a history imprecise in its becoming; a book that wreaks change on its time cannot fail to sow the seeds of change in the field of future transformations. If the Traité has something of both, it owes this to its radical bias, to the preponderance in it of that 'self' which is in the world without being of the world, that 'self' whose emancipation is a sine qua non for anyone who has discovered that learning to live is not the same thing as learning to survive.

In the early 1960s I conjectured that the examination of my own subjectivity, far from constituting an isolated activity, would resonate with other, like endeavours; and that if this examination was in tune with the times, it would in some way modulate those times in harmony with our desires.

To extend the ennui that textured my own everyday existence to a few others, and to enlist them in the dismal task of denouncing its causes, was not a little presumptuous on my part. But this consideration only increased the allure of betting on my presentiment that a passion for life was on the increase, a passion the impossibility of defining which contrasted dramatically with the acuteness of the criticism then being directed at the conditions ranged against it. ${ }^{2}$

\footnotetext{
${ }^{1}$ Paris: Gallimard, Collection Folio/Actuel,1992.

${ }^{2}$ The Traité was written between 1963 and 1965, and the manuscript sent to thirteen publishers, all of whom rejected it. The last refusal was from Gallimard, on whose reading committee the book was supported only by Raymond Queneau and Louis-René Des Forêts. As it happened, on the day the returned manuscript and Gallimard's rejection letter reached me, Le Figaro littéraire published an article decrying the influence of the situationists on the Provos of Amsterdam. That same evening Queneau sent me a telegram requesting that the manuscript be resubmitted. As a result I cut short a closing discussion of workers' councils as a social model (the book's second postscript, added in 1972, shows signs of an attempt to redress this). The Traité eventually appeared on 30 November 1967, six months before those events' which - precisely because their most innovative aspects are even now only just beginning to manifest themselves - are still not referred to as the Revolution of May 1968.
} 
In 1968 the barrier of prevailing sensibilities was brutally shattered by the vivisection of survival - a veritable alchemical opus nigrum. Thirty years on, consciousness is slowly opening itself up to a reversal of perspective in the light of which the world ceases to be apprehended as prey to a negative fate and begins instead to be ordered on the basis of a new positivity, on the basis of the recognition and expansion of the living forces within it.

Violence has changed its meaning. Not that the rebel has grown weary of fighting exploitation, boredom, poverty and death: the rebel has simply resolved no longer to fight them with the weapons of exploitation, boredom, poverty and death. For the first victim of any such struggle is anyone who engages in it full of contempt for their own life. Suicidal behaviour is naturally an integral part of a system that battens on the dilapidation of human nature as of nature tout court.

If the ancient cry "Death to the Exploiters" no longer echoes through the streets, it is because it has given way to another cry, one harking back to childhood and issuing from a passion which, though more serene, is no less tenacious. That cry is "Life First!"

The refusal of commodities implicit in the shattered plate-glass windows of 1968 marked such a clear and public breach in a millennia-old economic boundary-line drawn around individual destiny that archaic reflexes of fear and impotence immediately obscured the insurrectionary movement's truly radical character. I say 'truly radical' because here at long last was a chance to make the will to live that exists in each of us the basis for a society which for the first time in history would attain an authentic humanity.

Many people, however, treated this moment as an opportunity to set up shop as merchandisers of opposition, ignoring any need to change behaviour wedded to the mechanics of the commodity's rule. Among the Traité's readers there were thus some who seized upon my account of a certain mal de vivre (from which I wanted above all to free myself) as an excuse for offering no resistance whatsoever to the state of survival to which they were in thrall (and which the comforts of the welfare state, its abundant and bitter consolations, had until then concealed from them).

It was not long before these people had run up new character armour for themselves at the verbal forge of militant terrorism. Later still (without ever abandoning their incendiary rhetoric) they became career bureaucrats and covered themselves with glory as cogs in the apparat of State and marketplace.

In the 1960s a mutation of the economy took hold whose effects are increasingly evident today. With the benefit of hindsight I can now see much more easily how I was able to take advantage,

When the book came out, many readers claimed vociferously that the state of economic well-being then prevailing flatly contradicted my analysis of survival.

A comparable scepticism greeted Le Livre des plaisirs (Paris: Encre, 1979; English translation: The Book of Pleasures, London: Pending Press, 1983), published at a time when working and making money seemed to overshadow all other concerns. Likewise in the case of my Adresse aux vivants sur la mort qui les gouverne et l'opportunité de s'endéfaire (Address to the Living Concerning the Death that Rules over Them, and the Opportuneness of the Present Moment for Ridding Themselves Thereof) (Paris: Seghers,1990): the object of mockery now was no longer the critique of survival but rather the raising of the banner of a movement calling ever more clearly for "Life First!"

In 1967 many people deemed the notion of the "quality of lire vague and incomprehensible. It was not long before they were proved right, for a French government ministry shortly came into being with this very realm as its bailiwick. All the same, everything today suggests an urgent need, both individually and collectively, to give the quality of life practical definition and ensure its dominion. Much the same might be said of the notions of transparency, participation, reversal of perspective and creativity - which last term, incidentally, I was asked at that time to replace on the grounds that it 'doesn't exist'. 
in effect, of a kind of interregnum - during which the old authority was losing its grip but the new had still not thoroughly consolidated its power - to rescue subjectivity from the general opprobrium which then covered it and to propose, as the basis of a projected society, an enjoyment of self that proclaimed itself one with enjoyment of the world.

To begin with there were three or four of us who partook of, and shared amongst us, the passion for 'constructing situations. Phe way each cultivated this passion at that time depended on each's goals for his own existence, but it has lost nothing of its urgency, as witness both the inexorable advance of the life forces and the investments that an ecological neo-capitalism is obliged to make in them.

The last thirty years have visited more upheavals upon the world than the several millennia that proceeded them. That the Traité should in the slightest way have contributed to the acceleration thus suddenly imposed upon events is in the end for less a source of satisfaction to me than the sight of the paths now being opened up, within some individuals and some societies, that will lead from the primacy now at long last accorded to life to the likely creation of an authentically human race.

May 1968 was a genuine decanting, from the kind of revolution which revolutionaries make against themselves, of that permanent revolution which is destined to usher in the sovereignty of life.

There has never been a revolutionary movement not governed from start to finish by the expanding empire of the commodity. The economy, with its iron collar of archaic forms, has always smashed revolution by means of freedoms, modelled on the freedom of commerce, which because of the inherent constraints of the law of profit swiftly become the building-blocks of new tyrannies.

In the end the economy picks up whatever it has put in at the outset, plus appreciation. This is the whole meaning of the notion of 'recuperation'. Revolutions have never done anything but turn on themselves and negate themselves at the velocity of their own rotation. The revolution of 1968 was no exception to this rule. The commodity system, finding generalised consumption more profitable than production, itself speeds up the shift from authoritarianism to the seductions of the market, from saving to spending, from puritanism to hedonism, from an exploitation that sterilises the earth and mankind to a lucrative reconstruction of the environment, from capital as more precious than the individual to the individual as the most precious capital.

The impetus of the 'free' market has reunified the capitalist system by precipitating the collapse of bureaucratic, so-called communist, state capitalism. The Western model has made tabula rasa of the old forms of oppression and instated a democracy of the supermarket, a self-service autonomy, a hedonism whose pleasures must be paid for. Its racketeering has exploded all the great ideological balloons of earlier times, so laboriously inflated from generation to generation by the winds of the political seasons. A flea market of religion has been set up alongside the sleaze merchants and the shopping centres. The system has realised in the nick of time that a living human being is more of a paying proposition than a dead human being - or one riddled by pollutants. A fact proved, if proof were needed, by the rise of a vast market of the affections - an industry for extracting profits from the heart.

Even the critique of the spectacle has now been travestied as 'critical' spectacle. With the saturation of the market for denatured, tasteless, useless products, consumers unable to proceed any farther down the road of stupidity and passivity find themselves propelled into a competing market where profitability is predicated on the suggestions of quality and 'naturalness'. Suddenly 
we are obliged willy-nilly to demonstrate discernment - to retrieve the shreds of intelligence that old-style consumerism forebade us to use.

Power, State, religion, ideology, army, morality, the Left, the Right - that so many abominations should have been sent one after another to the wrecker's yard by the imperialism of the market, for which there is no black and no white, might seem at first glance good reason to rejoice; but no sooner does the slightest suspicion enter one?s mind than it becomes obvious that all the forces have simply redeployed, and are now waging the same war under different colours. Green, lest we forget, is also the colour of the dollar bill. The new and improved consumerism may be democratic, it may be ironic, but it always presents its bill, and the bill must always be paid. A life governed by a sanctioned greed is by no means freed thereby from the old tyranny of having to forfeit one's life simply to pay for it.

If there is one area where the achievement of consciousness comes into its own as a truly essential act, it is the realm of everyday life, where every passing instant reveals once again that the dice are loaded and that as per usual we are being taken for a ride.

From the agrarian structures that gave birth to the first City-States, to the world-wide triumph of the free market, the history of the commodity system has continually oscillated between a closed economy and an open one, between withdrawal into protectionism and embrace of the free circulation of goods. Each advance of the commodity has engendered on the one hand formal liberties, and on the other a consciousness enjoying the incalculably great advantage over those liberties of potential incarnation within the individual, potential conflation with the very movement of desire.

The first reaction of the ideology of freedom which rode the wave of all past revolutions, from the communalist insurrections of the eleventh and twelfth centuries to $1789,1848,1871,1917$ and 1936, was to drown all libidinal exuberance in blood (such exuberance was in any case itself largely restricted to bloody violence as a way of letting off steam).

Only one revolution (apropos of which it will someday be acknowledged that, in sharp contrast to all its predecessors, it truly wrote finis to several millennia of inhumanity) did not end in the whirlwind of repressive violence. In fact it simply did not end at all.

In 1968 the economy closed the circle: it reached its apogee and plunged into nothingness. This was the moment when it abandoned the authoritarian puritanism of the production imperative for the (more profitable) market in individual satisfaction. The suffusion of attitudes and mores by permissiveness echoed the official worlds recognition of pleasure - so long, of course, as the pleasure in question was a profitable one, tagged with an exchange value and wrested from the gratuitousness of real life to serve a new commodity order.

And then the game was over. Cool calculation had drawn too close to the heat of passion. The danger was that the will to live, aroused and denied simultaneously, would end by exposing the artificiality of the market's definition of freedom. Where was the silver-tongued lie that would serve business's ecological new look by promoting the timidest imaginable defence of life forces while still preventing individuals from reconstructing both their desires and their environment as part of an indivisible process?

A fate that has enthralled fomentors of revolution from time immemorial dictated that the 1968ers must eventually go where the economy beckoned: to modernity for the economy - and to ruin for them. If this fate was defied in 1968, it was thanks to a subjective consciousness of where real life lay. The rejection of work, sacrifice, guilt, separation, exchange, survival, so easily co-optable by an intellectual discourse, drew nourishment on this occasion from a lucidity that 
went far beyond contestation (or perhaps rather stopped far short of it) by hewing to the quest for a honing of desire, by remaining beholden to the everyday childhood of a life locked in combat with everything that sought to exhaust and destroy it.

A consciousness severed from the living forces is blind. The dark glasses of the negative at first obscure the fact that what seems like progress is working against us. The only consistency in the social analyses of our fashionable thinkers is the formidable tenacity with which they cling to their laughable claims. Revolution, self-management, workers' councils - so many words held up to public opprobrium at the very moment when state power is put on the defensive by groups whose collective decision-making admits of no intrusion by political representatives, shuns all organisers or leaders and combats all hierarchy.

I do not mean to downplay the shortcomings of a practice of this kind, which has for the most part been confined to reactions of a defensive nature. It cannot be denied, however, that it is a manifestation, bearing no appellation d'origine controlée, of a type of behaviour that breaks utterly with the old mass movements: a coming together of individuals in no way reducible to a crowd manipulable at will.

Everyday life itself is even more full of shortcomings - one has but to consider how little light is shed on it by those who wander about at the whim of its pleasures and pains.

After all, the Judaeo-Christian era itself had to end before we found out that the grimy word concealed a reality long overlain by that mere survival to which all life had been reduced by the cycle of the commodity, which mankind produces and which reproduces mankind in its own image.

There is no one who is not embarked upon a process of personal alchemy, yet so inattentive, so short-sighted are those who call their own passivity and resignation 'fate' that the magistery cannot operate in the light, cannot emerge from the atmosphere of putrefaction and death which characterises the daily grind of desires forced to deny themselves.

The feeling (inevitably a desperate one) of having fallen victim to a universal conspiracy of hostile circumstances is contrary to any will to autonomy. The negative is nothing but an excuse for resigning oneself never to be oneself, never to grasp the riches of one's own life. My goal, instead, has been a lucidity grounded in my desires; by continually illuminating the struggle between the living forces and living death, such a lucidity must surely combat the commodity's logic of etiolation.

As a sort of research report, a single book has neither the best nor yet the most insignificant role to play in the passionate day-to-day struggle to winnow out from my life whatever blocks or depletes it. The present work, Le Livre des plaisirs and L'Adresse aux vivants may be seen as three phases of a continuum in which a number of concordances have emerged between a mutating world and footholds secured from time to time in the persistent attempt to create myself and reconstruct society at the same time.

The falling rate of a profit derived from the exploitation and destruction of nature has been the determining factor in the late-twentieth century development of an ecological neo-capitalism and of new modes of production. The profitability of the living forces is no longer founded upon their exhaustion but rather on their reconstruction. Consciousness of the life to be created progresses because the sense of things themselves contributes to it. Never have desires, returned now to their childhood, enjoyed such power within each individual to smash everything that turns them upside down, everything that denies them and reifies them and makes them into commodities. 
Something is taking place today which no imagination has ever dared speculate upon: the process of individual alchemy is on the point of transmuting an inhuman history into nothing less than humanity's self-realisation.

September 1991 


\section{Introduction}

I have no intention of revealing what there is of my life in this book to readers who are not prepared to relive it. I await the day when it will lose and find itself in a general movement of ideas, just as I like to think that the present conditions will be erased from the memories of men.

The world must be remade; all the specialists in reconditioning will not be able to stop it. Since I do not want to understand them, I prefer that they should not understand me.

As for the others, I ask for their goodwill with a humility they will not fail to perceive. I should have liked a book like this to be accessible to those minds least addled by intellectual jargon; I hope I have not failed absolutely. One day a few formulae will emerge from this chaos and fire point-blank on our enemies. Till then these sentences, read and re-read, will have to do their slow work. The path toward simplicity is the most complex of all, and here in particular it seemed best not to tear away from the commonplace the tangle of roots which enable us to transplant it into another region, where we can cultivate it to our own profit.

I have never pretended to reveal anything new or to launch novelties onto the culture market. A minute correction of the essential is more important than a hundred new accessories. All that is new is the direction of the current which carries commonplaces along.

For as long as there have been men - and men who read Lautréamont - everything has been said and few people have gained anything from it. Because our ideas are in themselves commonplace, they can only be of value to people who are not.

The modern world must learn what it already knows, become what it already is, by means of a great work of exorcism, by conscious practice. One can escape from the commonplace only by manhandling it, mastering it, steeping it in dreams, giving it over to the sovereign pleasure of subjectivity. Above all I have emphasized subjective will, but nobody should criticize this until they have examined the extent to which the objective conditions of the contemporary world are furthering the cause of subjectivity day by day. Everything starts from subjectivity, and nothing stops there. Today less than ever.

From now on the struggle between subjectivity and what degrades it will extend the scope of the old class struggle. It revitalizes it and makes it more bitter. The desire to live is a political decision. We do not want a world in which the guarantee that we will not die of starvation is bought by accepting the risk of dying of boredom.

The man of survival is man ground up by the machinery of hierarchical power, caught in a mass of interferences, a tangle of oppressive techniques whose rationalization only awaits the patient programming of programmed minds.

The man of survival is also self-united man, the man of total refusal. Not a single instant goes by without each of us living contradictorily, and on every level of reality, the conflict between oppression and freedom, and without this conflict being strangely deformed, and grasped at the same time in two antagonistic perspectives: the perspective of power and the perspective of supersession. The two parts of this book, devoted to the analysis of these two perspectives, should thus be approached, not in succession, as their arrangement demands, but simultaneously, 
since the description of the negative founds the positive project and the positive project confirms negativity. The best arrangement of a book is none at all, so that the reader can discover his own.

Where the writing fails it reflects the failure of the reader as a reader, and even more as a man. If the element of boredom it cost me to write it comes through when you read it, this will only be one more argument demonstrating our failure to live. For the rest, the gravity of the times must excuse the gravity of my tone. Levity always falls short of the written words or overshoots them. The irony in this case will consist in never forgetting that.

This book is part of a current of agitation of which the world has not heard the last. It sets forth a simple contribution, among others, to the recreation of the international revolutionary movement. Its importance had better not escape anybody, for nobody, in time, will be able to escape its conclusions.

My subjectivity and the Creator: This is too much for one brain.

- Lautréamont 


\section{Part I. The Perspective of Power}




\section{Chapter 1. The Insignificant Signified}

Because of its increasing triviality, everyday life has gradually become our central preoccupation (1). No illusion, sacred or deconsecrated (2), collective or individual, can hide the poverty of our daily actions any longer (3). The enrichment of life calls inexorably for the analysis of the new forms taken by poverty, and the perfection of the old weapons of refusal (4).

1

The history of our times calls to mind those Walt Disney characters who rush madly over the edge of a cliff without seeing it, so that the power of their imagination keeps them suspended in mid-air; but as soon as they look down and see where they are, they fall.

Contemporary thought, like Bosustov's heroes, can no longer rest on its own delusions. What used to hold it up, today brings it down. It rushes full tilt in front of the reality that will crush it: the reality that is lived every day.

Is this dawning lucidity essentially new? I don't think so. Everyday life always produces the demand for a brighter light, if only because of the need which everyone feels to walk in step with the march of history. But there are more truths in twenty-four hours of a man's life than in all the philosophies. Even a philosopher cannot ignore it, for all his self-contempt; and he learns this self-contempt from his consolation, philosophy. After somersaulting onto his own shoulders to shout his message to the world from a greater height, the philosopher finishes by seeing the world inside out; and everything in it goes askew, upside down, to persuade him that he is standing upright. But he cannot escape his own delirium; and refusing to admit it simply makes it more uncomfortable.

The moralists of the sixteenth and seventeenth centuries ruled over a stockroom of commonplaces, but took such pains to conceal this that they built around it a veritable palace of stucco and speculation. A palace of ideas shelters but imprisons lived experience. From its gates emerges a sincere conviction suffused with the Sublime Tone and the fiction of the 'universal man', but it breathes with perpetual anguish. The analyst tries to escape the gradual sclerosis of existence by reaching some essential profundity; and the more he alienates himself by expressing himself according to the dominant imagery of his time (the feudal image in which God, monarchy and the world are indivisibly united), the more his lucidity photographs the hidden face of life, the more it 'invents' the everyday.

Enlightenment philosophy accelerated the descent towards the concrete insofar as the concrete was in some ways brought to power with the revolutionary bourgeoisie. From the ruin of Heaven, man fell into the ruins of his own world. What happened? Something like this: ten thousand people are convinced that they have seen a fakir's rope rise into the air, while as many cameras 
prove that it hasn't moved an inch. Scientific objectivity exposes mystification. Very good, but what does it show us? A coiled rope, of absolutely no interest. I have little to choose between the doubtful pleasure of being mystified and the tedium of contemplating a reality which does not concern me. A reality which I have no grasp on, isn't this the old lie re-conditioned, the ultimate stage of mystification?

From now on the analysts are in the streets. Lucidity isn't their only weapon. Their thought is no longer in danger of being imprisoned, either by the false reality of gods, or by the false reality of technocrats!

\section{2}

Religious beliefs concealed man from himself; their Bastille walled him up in a pyramidal world with God at the summit and the king just below. Alas, on the fourteenth of July there wasn't enough freedom to be found among the ruins of unitary power to prevent the ruins themselves from becoming another prison. Behind the rent veil of superstition appeared, not naked truth, as Meslier had dreamed, but the birdlime of ideologies. The prisoners of fragmentary power have no refuge from tyranny but the shadow of freedom.

Today there is not an action or a thought that is not trapped in the net of received ideas. The slow fall-out of particles of the exploded myth spreads sacred dust everywhere, choking the spirit and the will to live. Constraints have become less occult, more blatant; less powerful, more numerous. Docility no longer emanates from priestly magic, it results from a mass of minor hypnoses: news, culture, town-planning, publicity, mechanisms of conditioning and suggestion in the service of any order, established or to come. We are like Gulliver lying stranded on the Lilliputian shore with every part of his body tied down; determined to free himself, he looks keenly around him: the smallest detail of the landscape, the smallest contour of the ground, the slightest movement, everything becomes a sign on which his escape may depend. The most certain chances of liberation are born in what is most familiar. Was it ever otherwise? Art, ethics, philosophy bear witness: under the crust of words and concepts, the living reality of non-adaptation to the world is always crouched, ready to spring. Since neither gods nor words can mange to cover it up decently any longer, this commonplace creature roams naked in railway stations and vacant lots; it confronts you at each evasion of yourself, it touches your elbow, catches your eye; and the dialogue begins. You must lose yourself with it or save it with you.

\section{3}

Too many corpses strew the paths of individualism and collectivism. Under two apparently contradictory rationalities has raged an identical gangsterism, an identical oppression of the isolated man. The hand which smothered Lautréamont returned to strangle Serge Yesenin; one died in the lodging house of his landlord Jules-Françoise Dupuis, the other hung himself in a nationalized hotel. Everywhere the law is verified: "There is no weapon of your individual will which, once appropriated by others, does not turn against you." If anyone says or writes that practical reason must henceforth be based upon the rights of the individual and the individual alone, he invalidates his own proposition if he doesn't invite his audience to make this statement true for themselves. Such a proof can only be lived, grasped from the inside. That is why everything in 
the notes which follow should be tested and corrected by the immediate experience of everyone. Nothing is so valuable that it need not be started afresh, nothing is so rich that it need not be enriched constantly.

Just as we distinguish in private life between what a man thinks and says about himself and what he really is and does, everyone has learned to distinguish the rhetoric and the messianic pretensions of political parties from their organization and real interests: what they think they are, from what they are. A man's illusions about himself and others are not basically different from the illusions which groups, classes, and parties have about themselves. Indeed, they come from the same source: the dominant ideas, which are the ideas of the dominant class, even if they take an antagonistic form.

The world of isms, whether it envelops the whole of humanity or a single person, is never anything but a world drained of reality, a terribly real seduction by falsehood. The three crushing defeats suffered by the Commune, the Spartakist movement and the Kronstadt sailors showed once and for all what bloodbaths are the outcome of three ideologies of freedom: liberalism, socialism, and Bolshevism. However, before this could be universally understood and admitted, bastard or hybrid forms of these ideologies had to vulgarize their initial atrocity with more telling proofs: concentration camps, Lacoste's Algeria, Budapest. The great collective illusions, anaemic after shedding the blood of so many men, have given way to the thousands of pre-packed ideologies sold by consumer society like so many portable brain-scrambling machines. Will it need as much blood again to show that a hundred thousand pinpricks kill as surely as a couple of blows with a club?

What am I supposed to do in a group of militants who expect me to leave in the cloakroom, I won't say a few ideas - for my ideas would have led me to join the group - but the dreams and desires which never leave me, the wish to live authentically and without restraint? What's the use of exchanging one isolation, one monotony, one lie for another? When the illusion of real change has been exposed, a mere change of illusion becomes intolerable. But present conditions are precisely these: the economy cannot stop making us consume more and more, and to consume without respite is to change illusions at an accelerating pace which gradually dissolves the illusion of change. We find ourselves alone, unchanged, frozen in the empty space behind the waterfall of gadgets, family cars and paperbacks.

people without imagination are beginning to tire of the importance attached to comfort, to culture, to leisure, to all that destroys imagination. This means that people are not really tired of comfort, culture and leisure but of the use to which they are put, which is precisely what stops us enjoying them.

The affluent society is a society of voyeurs. To each his own kaleidoscope: a tiny movement of the fingers and the picture changes. You can't lose: two fridges, a mini-car, TV, promotion, time to kill... then the monotony of the images we consume gets the upper hand, reflecting the monotony of the action which produces them, the slow rotation of the kaleidoscope between finger and thumb. There was no mini-car, only an ideology almost unconnected with the automobile 
machine. Flushed with Pimm's No.1, we savour a strange cocktail of alcohol and class struggle. Nothing surprising any more, there's the rub! The monotony of the ideological spectacle makes us aware of the passivity of life: survival. Beyond the pre-fabricated scandals - Scandale perfume, Profumo scandal - a real scandal appears, the scandal of actions drained of their substance to the profit of an illusion which the failure of its enchantment renders more odious every day. Actions weak and pale from nourishing dazzling imaginary compensations, actions pauperized by enriching lofty speculations into which they entered like menials through the ignominious category of 'trivial' or 'commonplace', actions which today are free but exhausted, ready to lose their way once more, or expire under the weight of their own weakness. There they are, in every one of you, familiar, sad, newly returned to the immediate, living reality which was their birthplace. And here you are, bewildered and lost in a new prosaism, a perspective in which near and far coincide.

\section{4}

The concept of class struggle constituted the first concrete, tactical marshalling of the shocks and injuries which men live individually; it was born in the whirlpool of suffering which the reduction of human relations to mechanisms of exploitation created everywhere in industrial societies. It issued from a will to transform the world and change life.

Such a weapon needed constant adjustment. yet we see the First International turning its back on artists by making workers' demands the sole basis of a project which Marx had shown to concern all those who sought, in the refusal to be slaves, a full life and a total humanity. Lacenaire, Borel, Lassailly, Buchner, Baudelaire, Hölderlin - wasn't this also misery and its radical refusal? perhaps this mistake was excusable then: I neither know nor care. What is certain is that it is sheer madness a century later, when the economy of consumption is absorbing the economy of production, and the exploitation of labour power is submerged by the exploitation of everyday creativity. The same energy is torn from the worker in his hours of work and in his hours of leisure to drive the turbines of power, which the custodians of the old theory lubricate sanctimoniously with their purely formal opposition.

People who talk about revolution and class struggle without referring explicitly to everyday life, without understanding what is subversive about love and what is positive in the refusal of constraints, such people have corpses in their mouths. 


\section{Impossible Participation or Power As the Sum of Constraints}


The mechanisms of attrition and destruction: humiliation (two), isolation (three), suffering (four), work (five), decompression (six). 


\section{Chapter 2. Humiliation}

The economy of everyday life is based on a continuous exchange of humiliations and aggressive attitudes. It conceals a technique of wear and tear (usure), which is itself prey to the gift of destruction which it invites contradictorily (1). Today, the more man is a social being the more he is an object (2). Decolonisation has not yet begun (3). It will have to give a new value to the old principle of sovereignty (4).

\section{1}

One day, when Rousseau was travelling through a crowded village, he was insulted by a yokel whose spirit delighted the crowd. Rousseau, confused and discountenanced, couldn't think of a word in reply and was forced to take to his heels amidst the jeers of the crowd. By the time he had finally regained his composure and thought of a thousand possible retorts, any one of which would have silenced the joker once and for all, he was at two hours distance from the village.

Aren't most of the trivial incidents of everyday life like this ridiculous adventure? but in an attenuated and diluted form, reduced to the duration of a step, a glance, a thought, experienced as a muffled impact, a fleeting discomfort barely registered by consciousness and leaving in the mind only the dull irritation at a loss to discover its own origin? The endless minuet of humiliation and its response gives human relationships an obscene hobbling rhythm. In the ebb and flow of the crowds sucked in and crushed together by the coming and going of suburban trains, and coughed out into streets, offices, factories, there is nothing but timid retreats, brutal attacks, smirking faces and scratches delivered for no apparent reason. Soured by unwanted encounters, wine turns to vinegar in the mouth. Innocent and good-natured crowds? What a laugh! Look how they bristle up, threaten on every side, clumsy and embarrassed in the enemy's territory, far, very far from themselves. Lacking knives, they learn to use their elbows and their eyes.

There is no intermission, no truce between attackers and attacked. A flux of barely perceptible signs assails the walker, who is not alone. Remarks, gestures, glances tangle and collide, miss their aim, ricochet like bullets fired at random, which kill even more surely by the continuous nervous tension they produce. All we can do is to enclose ourselves in embarrassing parentheses; like these fingers (I am writing this on a cafe terrace) which slide the tip across the table and the fingers of the waiter which pick it up, while the faces of the two men involved, as if anxious to conceal the infamy which they have consented to, assume an expression of utter indifference.

From the point of view of constraint, everyday life is governed by an economic system in which the production and consumption of insults tends to balance out. The old dream of the theorists of perfect competition thus finds its real perfection in the customs of a democracy given new life by the lack of imagination of the left. Isn't it strange, at first sight, to see the fury with which 'progressives' attack the ruined edifice of free enterprise, as if the capitalists, its official demolition gang, had not themselves already planned its nationalized reconstruction? but it is not so strange, in fact: for the deliberate purpose of keeping all attention fastened on 
critiques which have already been overtaken by events (after all, anybody can see that capitalism is gradually finding its fulfillment in a planned economy of which the Soviet model is nothing but a primitive form) is to conceal the fact that the only reconstruction of human relationships envisaged is one based upon precisely this economic model, which, because it is obsolete, is available at a knock-down price. Who can fail to notice the alarming persistence with which 'socialist' countries continue to organize life along bourgeois lines? Everywhere it's hats off to family, marriage, sacrifice, work, inauthenticity, while simplified and rationalized homeostatic mechanisms reduce human relationships to 'fair' exchanges of deference and humiliation. And soon, in the ideal democracy of the cyberneticians, everyone will earn without apparent effort a share of unworthiness which he will have the leisure to distribute according to the finest rules of justice. Distributive justice will reach its apogee. Happy the old men who live to see the day!

For me - and for some others, I dare to think - there can be no equilibrium in malaise. Planning is only the antithesis of the free market. Only exchange has been planned, and with it the mutual sacrifice which it entails. But if the word 'innovation' is to keep its proper meaning, it must mean superseding, not tarting up. In fact, a new reality can only be based on the principle of the gift. Despite their mistakes and their poverty, I see in the historical experiences of workers' councils $(1917,1921,1934,1956)$, and in the pathetic search for friendship and love, a single and inspiring reason not to despair over present 'reality'. Everything conspires to keep secret the positive character of such experiences; doubt is cunningly maintained as to their real importance, even their existence. By a strange oversight, no historian has ever taken the trouble to study how people actually lived during the most extreme revolutionary moments. At such times, the wish to make an end of free exchange in the market of human behaviour shows itself spontaneously but in the form of negation. When malaise is brought into question it shatters under the onslaught of a greater and denser malaise.

In a negative sense, Ravachol's bombs or, closer to our own time, the epic of Caraquemada dispel the confusion which reigns around the total rejection - manifested to a varying extent, but manifested everywhere - of relationships based on exchange and compromise. I have no doubt, since I have experienced it so many times, that anyone who passes an hour in the cage of constraining relationships feels a profound sympathy for Pierre-François Lacenaire and his passion for crime. The point here is not to make an apology for terrorism, but to recognize it as an action - the most pitiful action and at the same time the most noble - which is capable of disrupting and thus exposing the self-regulating mechanisms of the hierarchical social community. Inscribed in the logic of an unlivable society, murder thus conceived can only appear as the concave form of the gift. it is that absence of an intensely desired presence that Mallarmé described; the same Mallarmé who, at the trial of the Thirty, called the anarchists 'angels of purity'.

My sympathy for the solitary killer ends where tactics begin; but perhaps tactics need scouts driven by individual despair. However that may be, the new revolutionary tactics - which will be based indissolubly on the historical tradition and on the practice, so widespread and so disregarded, of individual realization - will have no place for people who only want to mimic the gestures of Ravachol or Bonnot. But on the other hand these tactics will be condemned to theoretical hibernation if they cannot, by other means, attract collectively the individuals whom isolation and hatred for the collective lie have already won over to the rational decision to kill or to kill themselves. No murderers - and no humanists either! The first accept death, the second impose it. let ten men meet who are resolved on the lightning of violence rather than the long agony of 
survival; from this moment, despair ends and tactics begin. Despair is the infantile disorder of the revolutionaries of everyday life.

I still feel today my adolescent admiration for outlaws, not because of an obsolete romanticism but because they expose the alibis by which social power avoids being put right on the spot. Hierarchical social organization is like a gigantic racket whose secret, precisely exposed by anarchist terrorism, is to place itself out of reach of the violence it gives rise to, by consuming everybody's energy in a multitude of irrelevant struggles. (A 'humanized' power cannot allow itself recourse to the old methods of war and genocide.) The witnesses for the prosecution can hardly be suspected of anarchist tendencies. The biologist Hans Selye states that "as specific causes of disease (microbes, undernourishment) disappear, a growing proportion of people die of what are called stress diseases, or diseases of degeneration caused by stress, that is, by the wear and tear resulting from conflicts, shocks, nervous tension, irritations, debilitating rhythms..." From now on, no-one can escape the necessity of conducting his own investigation into the racket which pursues him even into his thoughts, hunts him down even in his dreams. The smallest details take on a major importance. irritation, fatigue, rudeness, humiliation... cui bono? Who profits by them? And who profits by the stereotyped answers that Big Brother Common Sense distributes under the label of wisdom, like so many alibis? Shall I be content with explanations that kill me when I have everything to win in a game where all the cards are stacked against me?

\section{2}

The handshake ties and unties the knot of encounters. A gesture at once curious and trivial which the French quite accurately say is exchanged: isn't it in fact the most simplified form of the social contract? What guarantees are they trying to seal, these hands clasped to the right, to the left, everywhere, with a liberality that seems to make up for a total lack of conviction? That agreement reigns, that social harmony exists, that life in society is perfect? But what still worries us is this need to convince ourselves, to believe it by force of habit, to reaffirm it with the strength of our grip.

Eyes know nothing of these pleasantries; they do not recognize exchange. When our eyes meet someone else's they become uneasy, as if they could make out their own empty, soulless reflection in the other person's pupils. Hardly have they met when they slip aside and try to dodge one another; their lines of flight cross in an invisible point, making an angle whose acuteness expresses the divergence, the deeply felt lack of harmony. Sometimes unison is achieved and eyes connect; the beautiful parallel stare of royal couples in Egyptian sculpture, the misty, melting gaze, brimming with eroticism, of lovers: eyes which devour one another from afar. But most of the time the eyes repudiate the superficial agreement sealed by the handshake. Consider the popularity of the energetic reiteration of social agreement (the phrase 'let's shake on it' indicates its commercial overtones): isn't it a trick played on the senses, a way of dulling the sensitivity of the eyes so that they don't revolt against the emptiness of the spectacle? The good sense of consumer society has brought the old expression 'see things my way' to its logical conclusion: whichever way you look, you see nothing but things.

Become as senseless and easily handled as a brick!

That is what social organization is kindly inviting everyone to do. The bourgeoisie has managed to share out irritations more fairly, allowing a greater number of people to suffer them 
according to rational norms (economic, social, political, legal necessities...) The splinters of constraint produced in this way have in turn fragmented the cunning and the energy devoted collectively to evading or smashing them. The revolutionaries of 1793 were great because they dared to usurp the unitary hold of God over the government of men; the proletarian revolutionaries drew from what they were defending a greatness that they could never have seized from the bourgeois enemy - their strength derived from themselves alone.

A whole ethic based on exchange value, the pleasures of business, the dignity of labour, restrained desires, survival, and on their opposites, pure value, the gratuitous, parasitism, instinctive brutality and death: this is the filthy tub that human faculties have been bubbling in for nearly two centuries. From these ingredients - refined a little of course - the cyberneticians are dreaming of cooking up the man of the future. Are we quite sure that we haven't yet arrived at the security of perfectly adapted beings, moving about as uncertainly and unconsciously as insects? For some time now there have been experiments with subliminal advertising: the insertion into films of single frames lasting $1 / 24$ of a second, which are seen by the eye but not registered by consciousness. The first slogans give more than a glimpse of what is to come: 'Don't drive too fast' and 'Go to church'. But what does a minor improvement like this represent in comparison with the whole immense conditioning machine ,each of whose cogs - town planning, publicity, ideology, culture - is capable of dozens of comparable improvements? Once again, knowledge of the conditions which are going to continue to be imposed on people if they don't look out is less relevant than the sensation of living in such degradation now. Zamiatin's We. Huxley's Brave New World, Orwell's 1984 and Touraine's Cinquieme Coup de Trompette push back into the future a shudder of horror which one look at the present would produce; and it is the present that develops consciousness and the will to refuse. Compared with my present imprisonment the future holds no interest for me.

The feeling of humiliation is nothing but the feeling of being an object. Once it has been understood as such, it becomes the basis for a combative lucidity for which the critique of the organization of life cannot be separated from the immediate inception of the project of living differently. Construction can begin only on the foundation of individual despair and its supersession; the efforts made to disguise this despair and pass it off under another wrapper are enough to prove it.

What is the illusion which stops us seeing the disintegration of values, the ruin of the world, inauthenticity, non-totality?

Is it that I think that I am happy? Hardly! Such a belief doesn't stand up to analysis any better than it withstands the blasts of anguish. On the contrary, it is a belief in the happiness of others, an inexhaustible source of envy and jealousy which gives us a vicarious feeling of existence. I envy, therefore I am. To define oneself by reference to others is to define oneself as other. And the other is always object. So that life is measured in degrees of humiliation, the more you 'live': the more you live the orderly life of things. Here is the cunning of reification, by which it passes undetected, like arsenic in the jam.

The gentleness of these methods of oppression throws a certain light on the perversion which prevents me from shouting out "The emperor has no clothes!" each time the sovereignty of my everyday life reveals its poverty. Obviously police brutality is still going strong, to say the least. 
Everywhere it raises its head the kindly souls of the left quite rightly condemn it. But what do they do about it? Do they urge people to arm themselves? Do they call for legitimate reprisals? Do they encourage pig-hunts like the one which decorated the trees of Budapest with the finest fruits of the AVO? No: they organize peaceful demonstrations at which their trade-union police force treats anyone who questions their orders as an agent provocateur. The new policemen are ready to take over. The social psychologists will govern without truncheons: no more tough cops, only con cops. Oppressive violence is about to be transformed into a host of reasonably distributed pin-pricks. The same people who denounce police violence from the heights of their lofty ideals are urging us on toward a state based on polite violence.

Humanism merely upholsters the machine of Kafka's "Penal Colony". Less grinding and shouting! Blood upsets you? Never mind: men will be bloodless. The promised land of survival will be the realm of peaceful death, and it is this peaceful death that the humanists are fighting for. No more Guernicas, no more Auschwitzes, no more Hiroshimas, no more Setifs. Hooray! But what about the impossibility of living, what about this stifling mediocrity and this absence of passion? What about the jealous fury in which the rankling of never being ourselves drives us to imagine that other people are happy? What about this feeling of never really being inside your own skin? let nobody say these are minor details or secondary points. There are no negligible irritations; gangrene can start in the slightest graze. The crises that shake the world are not fundamentally different from the conflicts in which my actions and thoughts confront the hostile forces that entangle and deflect them. (How could it be otherwise when history, in the last analysis, is only important to me in so far as it affects my own life?) Sooner or later the continual division and re-division of aggravations will split the atom of unlivable reality and liberate a nuclear energy which nobody suspected behind so much passivity and gloomy resignation. That which produces the common good is always terrible.

3

From 1945 to 1960, colonialism was a fairy godmother to the left. With a new enemy on the scale of Fascism, the left never had to define itself positively, starting from itself (there was nothing there); it was ale to affirm itself by negating something else. In this way it was able to accept itself as a thing, part of an order of things in which things are everything and nothing.

Nobody dared to announce the end of colonialism for fear that it would spring up all over the place like a jack-in-the-box whose lid doesn't shut properly. In fact, from the moment when the collapse of colonial power revealed the colonialism inherent in all power over men, the problems of race and colour became about as important as crossword puzzles. What effect did the clowns of the left have as they trotted about on their anti-racialist and anti-anti-semitic hobbyhorses? In the last analysis, that of smothering the cries of tormented Jews and negroes which were uttered by all those who were not Jews or negroes, starting with the Jews and negroes themselves. Of course, I would not dream of questioning the spirit of generosity which has inspired recent antiracialism. But I lose interest in the past as soon as I can no longer affect it. I am speaking here and now, and nobody can persuade me, in the name of Alabama or South Africa and their spectacular exploitation, to forget that the epicentres of such problems lies in me and in each being who is humiliated and scorned by every aspect of our own society.

I shall not renounce my share of violence. 
Human relationships can hardly be discussed in terms of more or less tolerable conditions, more or less admissible indignities. Qualification is irrelevant. Do insults like 'wog' or 'nigger' hurt more than a word of command? When he is summoned, told off, or ordered around by a policeman, a boss, an authority, who doesn't feel deep down, in moments of lucidity, that he is a darkie and a gook?

The old colonials provided us with a perfect identi-kit portrait of power when they predicted the descent into bestiality and wretchedness of those who found their presence undesirable. Law and order come first, says the guard to the prisoner. Yesterday's anti-colonialists are trying to humanize the generalized colonialism of power. They become it's watchdogs in the cleverest way: by barking at all the after-effects of past inhumanity.

Before he tried to get himself made President of Martinique, Aimé Césaire made a famous remark: "The bourgeoisie has found itself unable to solve the major problems which its own existence has produced: the colonial problem and the problem of the proletariat." He forgot to add: "For they are one and the same problem, a problem which anyone who separates them will fail to understand."

4

I read in Gouy's Histoire de France: "The slightest insult to the King meant immediate death". In the American Constitution: "The people are sovereign". In Pouget's Père Peinard: "Kings get fat off their sovereignty, while we are starving on ours". Courbon's Secret du Peuple tells me: "The people today means the mass of men to whom all respect is denied". Here we have, in a few lines, the misadventures of the principle of sovereignty.

Kings designated as 'subjects' the objects of their arbitrary will. No doubt this was an attempt to wrap the radical inhumanity of its domination in a humanity of idyllic bonds. The respect due to the king's person cannot in itself be criticized. It is odious only because it is based on the right to humiliate by subordination. Contempt rotted the thrones of kings. But what about the citizen's sovereignty: the rights multiplied by bourgeois vanity and jealousy, sovereignty distributed like a dividend to each individual? What about the divine right of kings democratically shared out?

Today, France contains twenty-four million mini-kings, of which the greatest - the bosses - are great only in their ridiculousness. The sense of respect has become degraded to the point where humiliation is all that it demands. Democratized into public functions and roles, the monarchic principle floats with its belly up, like a dead fish: only its most repulsive aspect is visible. Its will to be absolutely and unreservedly superior has disappeared. Instead of basing our lives on our sovereignty, we try to base our sovereignty on other people's lives. The manners of slaves. 


\title{
Chapter 3. Isolation
}

\author{
Para no sentirme solo \\ por los siglos de los siglos
}

All we have in common is the illusion of being together. And beyond the illusion of permitted anodynes there is only the collective desire to destroy isolation (1). - Impersonal relationships are the no-man's land of isolation. By producing isolation, contemporary social organization signs its own death-sentence (2).

1

It was as if they were in a cage whose door was wide open without their being able to escape. Nothing outside the cage had any importance, because nothing else existed any more. They stayed in the cage, estranged from everything except the cage, without even a flicker of desire for anything outside the bars. it would have been abnormal - impossible in fact - to escape into something which had neither reality nor importance. Absolutely impossible. For inside this cage, in which they had been born and in which they would die, the only tolerable framework of experience was the Real, which was simply an irresistible instinct to act so that things should have importance. Only if things had some importance could one breathe, and suffer. it seemed that there was an understanding between them and the silent dead that it should be so, for the habit of acting so that things had some importance had become a human instinct, and one which was apparently eternal. Life was the important thing, and the Real was part of the instinct which gave life a little meaning. The instinct didn't try to imagine what might lie beyond the Real, because there was nothing beyond it. Nothing important. The door remained open and the cage became more and more painful in its Reality which was so important for countless reasons and in countless ways.

We have never emerged from the times of the slavers.

On the public transport which throws them against one another with statistical indifference, people wear an untenable expression of disillusion, pride and contempt, like the natural effect of death on a toothless mouth. The atmosphere of false communication makes everyone the policeman of his own encounters. The instincts of flight and aggression trail the knights of wagelabour, who must now rely on subways and suburban trains for their pitiful wanderings. If men were transformed into scorpions who sting themselves and one another, isn't it really because nothing has happened, and human beings with empty eyes and flabby brains have 'mysteriously' become mere shadows of men, ghosts of men, and in some ways are no longer men except in name?

We have nothing in common except the illusion of being together. Certainly the seeds of an authentic collective life are lying dormant within the illusion itself - there is no illusion without a real basis - but real community remains to be created. The power of the lie sometimes manages 
to erase the bitter reality of isolation from men's minds. In a crowded street we can occasionally forget that suffering and separation are still present. And, since it is only the lie's power which makes us forget, suffering and separation are reinforced; but in the end the lie itself comes to grief through relying on this support. For a moment comes when no illusion can measure up to our distress.

Malaise invades me as the crows around me grows. The compromises I have made with stupidity under the pressure of circumstances rush to meet me, swimming towards me in hallucinating waves of faceless heads. Edvard Munch's famous painting, The Cry, evokes for me something I feel ten times a day. A man carried along by a crowd, which only he can see, suddenly screams out in an attempt to break the spell, to call himself back to himself, to get back inside his own skin. The tacit acknowledgments, fixed smiles, lifeless words, listlessness and humiliation sprinkled in his path suddenly surge into him, driving him out of his desires and his dreams and exploding the illusion of 'being together'. People touch without meeting; isolation accumulates but is never realized; emptiness overcomes us as the density of the crowd grows. The crowd drags me out of myself and installs thousands of little sacrifices in my empty presence.

Everywhere neon signs are flashing out the dictum of Plotinus: All beings are together though each remains separate. But we only need to hold out our hands and touch one another, to raise our eyes and meet one another, and everything comes into focus, as if by magic.

Like crowds, drugs, and love, alcohol can befuddle the most lucid mind. Alcohol turns the concrete wall of isolation into a paper screen which the actors can tear according to their fancy, for it arranges everything on the stage of an intimate theatre. A generous illusion, and thus still more deadly.

In a gloomy bar where everyone is bored to death, a drunken young man breaks his glass, then picks up a bottle and smashes it against the wall. Nobody gets excited; the disappointed young man lets himself be thrown out. Yet everyone there could have done exactly the same thing. He alone made the thought concrete, crossing the first radioactive belt of isolation: interior isolation, the introverted separation between self and outside world. Nobody responded to a sign which he thought was explicit. He remained alone like the hooligan who burns down a church or kills a policeman, at one with himself but condemned to exile as long as other people remain exiled from their own existence. He has not escaped from the magnetic field of isolation; he is suspended in a zone of zero gravity. All the same, the indifference which greets him allows him to hear the sound of his own cry; even if this revelation tortures him, he knows that he will have to start again in another register, more loudly; with more coherence.

People will be together only in a common wretchedness as long as each isolated being refuses to understand that a gesture of liberation, however weak and clumsy it may be, always bears an authentic communication, an adequate personal message. The repression which strikes down the libertarian rebel falls on everyone: everyone's blood flows with the blood of a murdered Durruti. Whenever freedom retreats one inch, there is a hundred-fold increase in the weight of the order of things. Excluded from authentic participation, men's actions stray into the fragile illusion of being together, or else into its opposite, the abrupt and total rejection of society. They swing from one to the other like a pendulum turning the hands on the clock-face of death. 
Love in its turn swells the illusion of unity. Most of the time it gets fucked up and miscarries. Its songs are crippled by fear of always returning to the same single note: whether there are two of us, or even ten, we will finish up alone as before. What drives us to despair is not the immensity of our own unsatisfied desires, but the moment when our newborn passion discovers its own emptiness. The insatiable desire to fall in love with so many pretty girls is born in anguish and the fear of loving: we are so afraid of never escaping from meetings with objects. The dawn when lovers leave each other's arms is the same dawn that breaks on the execution of revolutionaries without a revolution. Isolation a deux cannot confront the effect of general isolation. Pleasure is broken off prematurely and lovers find themselves naked in the world, their actions suddenly ridiculous and pointless. No love is possible in an unhappy world.

The boat of love breaks up in the current of everyday life.

Are you ready to smash the reefs of the old world before they wreck your desires? Lovers should love their pleasure with more consequence and more poetry. A story tells how Price Shekour captured a town and offered it to his favourite for a smile. Some of us have fallen in love with the pleasure of loving without reserve - passionately enough to offer our love to the magnificent bed of a revolution.

\section{2}

To adapt to the world is a game of heads-you-win, tails-I-lose in which one decides a priori that the negative is positive and that the impossibility of living is an essential precondition of life. Alienation never takes such firm root as when it passes itself off as an inalienable good. Transformed into positivity, the consciousness of isolation is none other than the private consciousness, that scrap of individualism which people drag around like their most sacred birthright, unprofitable but cherished. It is a sort of pleasure-anxiety which prevents us both from settling down in the community of illusion and from remaining trapped in the cellar of isolation.

The no-man's-land of impersonal relationships stretches between the blissful acceptance of false collectivities and the total rejection of society. It is the morality of shopkeepers: "You scratch my back, I'll scratch yours", "You mustn't let people get too familiar": politeness, the art (for art's sake) of non-communication.

Let's face it: human relationships being what social hierarchy has made them, impersonality is the least tiring form of contempt. It allows us to pass without useless friction through the mill of daily contacts. it does not prevent us dreaming of superior forms of civility, such as the courtesy of Lacenaire, on the eve of his execution, urging a friend: "Above all, please convey my gratitude to M.Scribe. Tell him that one day, suffering from the pangs of hunger, I presented myself at his house in order to worm some money out of him. He complied with my request with a touching generosity; I am sure he will remember. tell him that he acted wisely, for I had in my pocket, ready to hand, the means of depriving France of a dramatist."

But the sterilized zone of impersonal relationships only offers a truce in the endless battle against isolation, a brief transit which leads to communication, or more frequently towards the illusion of community. I would explain in this way my reluctance to stop a stranger to ask him the way or to 'pass the time of day': to seek contact in this doubtful fashion. The pleasantness of impersonal relationships is built on sand; and empty time never did me any good. 
Life is made impossible with such cynical thoroughness that the balanced pleasure-anxiety of impersonal relationships, functions as a cog in the general machine for destroying people. In the end it seems better to start out right away with a radical and tactically worked-out refusal, rather than to go around knocking politely on all the doors where one mode of survival is exchanged for another.

"It would be a drag to die so young". wrote Jacques Vaché two years before his suicide. if desperation at the prospect of surviving does not unite with a new grasp of reality to transform the years to come, only two ways out are left for the isolated man: the pisspot of parties and pataphysico-religious sects, or immediate death with Umour. A sixteen-year-old murderer recently explained: "I did it because I was bored." Anyone who has felt the drive to self-destruction welling up inside him knows with what weary negligence he might one day happen to kill the organizers of his boredom. One day. If he was in the mood.

After all, if an individual refuses both to adapt to the violence of the world, and to embrace the violence of the unadapted, what can he do? If he doesn't raise his will to achieve unity with the world and with himself to the level of coherent theory and practice, the vast silence of society's open spaces will raise around him the palace of solipsist madness.

From the depths of their prisons, those who have been convicted of 'mental illness' add the screams of their strangled revolt to the sum of negativity. What a potential Fourier was cleverly destroyed in this patient described by the psychiatrist Volnat: "He began to lose all capacity to distinguish between himself and the external world. Everything that happened in the world also happened in his body. He could not put a bottle between two shelves in a cupboard, because the shelves might come together and break the bottle. And that would hurt inside his head, as if his head were wedged between the shelves. He could not shut a suitcase, because pressing the things in the case would press inside his head. If he walked into the street after closing all the doors and windows of his house, he felt uncomfortable, because his brain was compressed by the air, and he had to go back home to open a door or a window. 'For me to be at ease,' he said, 'I must have open space. [...] I must have the freedom of my space. It's the battle with the things all around me."

"Outside the consul paused, turning... No se puede vivir sin amar, were the words on the house." (Lowry, Under the Volcano). 


\section{Chapter 4. Suffering}

Suffering caused by natural alienation has given way to suffering caused by social alienation, while remedies have become justifications (1). Where there is no justification, exorcism takes its place (2). But from now on no subterfuge can hide the existence of an organization based on the distribution of constraints (3). Consciousness reduced to the consciousness of constraints is the antechamber of death. The despair of consciousness makes the murderers of Order; the consciousness of despair makes the murderers of Disorder (4).

The symphony of spoken and shouted words animates the scenery of the streets. Over a rumbling basso continuo develop grave and cheerful themes, hoarse and singsong voices, nostalgic fragments of sentences. There is a sonorous architecture which overlays the outline of streets and buildings, reinforcing or counteracting the attractive or repulsive tone of a district. But from Notting Hill to Oxford Street the basic chord is the same everywhere: it's sinister resonance has sunk so deeply into everyone's mind that it no longer surprises them. "That's life", "These things are sent to try us", "You have to take the rough with the smooth", "That's the way it goes"... this lament whose weft unites the most diverse conversations has so perverted our sensibility that it passes for the commonest of human dispositions. Where it is not accepted, despair disappears from sight. Nobody seems worried that joy has been absent from European music for nearly two centuries; which says everything. Consume, consume: the ashes have consumed the fire.

How have suffering and it's rites of exorcism usurped this importance? Undoubtedly because of the struggle to survive imposed on the first men by a hostile nature, full of cruel and mysterious forces. In the face of danger, the weakness of men discovered in social agglomeration not only protection but a way of co-operating with nature, making a truce with her and even transforming her. In the struggle against natural alienation - death, sickness, suffering - alienation became social. We escaped the rigours of exposure, hunger and discomfort only to fall into the trap of slavery. We were enslaved by gods, by men, by language. And such a slavery had its positive side: there was a certain greatness of living in terror of a god who also made you invincible. This mixture of human and inhuman would, it is true, be a sufficient explanation of the ambiguity of suffering, its way of appearing right through history at once as shameful sickness and salutary evil - as a good thing, after a fashion. But this would be to overlook the ignoble slag of religion, above all Christian mythology, which devoted all its genius to perfecting this morbid and depraved precept: protect yourself against mutilation by mutilating yourself!

"Since Christ's coming, we are delivered not from the evil of suffering but from the evil of suffering uselessly", writes the Jesuit father Charles. How right he is: power's problem has always been, not to abolish itself, but to give itself reasons so as not to oppress 'uselessly'. Christianity, that unhealthy therapeutic, pulled off its masterstroke when it married man to suffering, whether on the basis of divine grace or natural law. From prince to manager, from priest to expert, from father confessor to social worker, it is always the principle of useful suffering and willing sacrifice which forms the most solid base for hierarchical power. Whatever reasons it invokes - a better world, the next world, building communism or fighting communism - suffering accepted is al- 
ways Christian, always. Today the clerical vermin have given way to the missionaries of a Christ dyed red. Everywhere official pronouncements bear in their watermark the disgusting image of the crucified man, everywhere comrades are urged to sport the stupid halo of the militant martyr. And with their blood, the kitchen-hands of the good Cause are mixing up the sausage-meat of the future: less cannon-fodder, more doctrine-fodder!

To begin with, bourgeois ideology seemed determined to root out suffering with as much persistence as it devoted to the pursuit of the religions that it hated. Infatuated with progress, comfort, profit, well-being, it had enough weapons - if not real weapons, at least imaginary ones - to convince everyone of its will to put a scientific end to the evil of suffering and the evil of faith. As we know, all it did was to invent new anaesthetics and new superstitions.

Without God, suffering became 'natural', inherent in 'human nature'; it would be overcome, but only after more suffering: the martyrs of science, the victims of progress, the lost generations. But in this very movement the idea of natural suffering betrayed its social root. When Human Nature was removed, suffering became social, inherent in social existence. But of course, revolutions demonstrated that the social evil of pain was not a metaphysical principle: that a form of society could exist from which the pain of living would be excluded. History shattered the social ontology of suffering, but suffering, far from disappearing, found new reasons for existence in the exigencies of History, which had suddenly become trapped, in its turn, in a one-way street. China prepares children for the classless society by teaching them love of their country, love of their family, and love of work. Thus historical ontology picks up the remains of all the metaphysical systems of the past: an sich, God, Nature, Man, Society. From now on, men will have to make history by fighting History itself, because History has become the last ontological earthwork of power, the last con by which it hides, behind the promise of a long weekend, its will to endure until Saturday which will never come. Beyond fetishised history, suffering is revealed as stemming from hierarchical social organization. And when the will to put an end to hierarchical power has sufficiently tickled the consciousness of men, everyone will admit that freedom in arms and weight of constraints have nothing metaphysical about them.

2

While it was placing happiness and freedom on the order of the day, technological civilization was inventing the ideology of happiness and freedom. Thus it condemned itself to creating no more than the freedom of apathy, happiness in passivity. But at least this invention, perverted though it was, had denied that suffering is inherent in the human condition, that such an inhuman condition could last forever. That is why bourgeois thought fails when it tries to provide consolation for suffering; none of its justifications are as powerful as the hope which was born from its initial bet on technology and well-being.

Desperate fraternity in sickness is the worst thing that can happen to civilization. In the twentieth century, death terrifies men less than the absence of real life. All these dead, mechanized, specialized actions, stealing a little bit of life a thousand times a day, until the exhaustion of mind and body, until that death which is not the end of life but the final saturation with absence; this is what lends a dangerous charm to dreams of apocalypses, gigantic destructions, complete 
annihilations, cruel, clean and total deaths. Auschwitz and Hiroshima are indeed the 'comfort of nihilism'. Let impotence in the face of suffering become a collective sentiment, and the demand for suffering and death can sweep a whole community. Consciously or not, most people would rather die than live a permanently unsatisfying life. Look at anti-bomb marchers: most of them were nothing but penitents trying to exorcise their desire to disappear with all the rest of humanity. They would deny it, of course, but their miserable faces gave them away. The only real joy is revolutionary.

Perhaps it is in order to ensure that a universal desire to perish does not take hold of men that a whole spectacle is organized around particular sufferings. A sort of nationalized philanthropy impels man to find consolation for his own infirmities in the spectacle of other people's.

Consider disaster photographs, stories of cuckolded singers, the ridiculous dramas of the gutter press; hospitals, asylums, and prisons: real museums of suffering for the use of those whose fear of entering them makes them happy to be outside. I sometimes feel such a diffuse suffering dispersed through me that I find relief in the chance misfortune that concretizes and justifies it, offers it a legitimate outlet. Nothing will dissuade me of this: the sadness I feel after a separation, a failure, a bereavement doesn't reach me from outside like an arrow but wells up from inside me like a spring freed by a landslide. There are wounds which allow the spirit to utter a long-stifled cry. Despair never lets go its prey; it is only the prey which isolates despair in the end of a love or the death of a child, where there is only its shadow. Mourning is a pretext, a convenient way of spitting out nothingness in small drops. The tears, the cries and howls of childhood remain imprisoned in the hearts of men. For ever? In you also the emptiness is growing.

\section{3}

Another word about the alibis of power. Suppose that a tyrant took pleasure in throwing prisoners who had been flayed alive into a small cell; suppose that to hear their screams and see them scramble each time they brushed against one another amused him a lot, at the same time causing him to meditate on human nature and the curious behaviour of men. Suppose that at the same time and in the same country there were philosophers and wise men who explained to the worlds of science and art that suffering had to do with the collective life of men, the inevitable presence of Others, society as such - wouldn't we be right to consider these men the tyrant's watchdogs? By proclaiming such theses as these, a certain existentialist conception has demonstrated not only the collusion of left intellectuals with power, but also the crude trick by which an inhuman social organization attributes the responsibility for its cruelties to its victims themselves. A nineteenth century critic remarked: "Throughout contemporary literature we find the tendency to regard individual suffering as a social evil and to make the organization of society responsible for the misery and degradation of its members. This is a profoundly new idea: suffering is no longer treated as a matter of fatality." Certain thinkers steeped in fatalism have not been troubled overmuch by such novelties: consider Sartre's hell-is-other-people, Freud's death instinct, Mao's historical necessity. After all, what distinguishes these doctrines from the stupid "it's just human nature"?

Hierarchical social organization is like a system of hoppers lined with sharp blades. While it flays us alive power cleverly persuades us that we are flaying each other. It is true that to limit 
myself to writing this is to risk fostering a new fatalism; but I certainly intend in writing it that nobody should limit himself to reading it.

Altruism is the other side of the coin of 'hell-is-other-people'; only this time mystification appears under a positive sign. Let's put an end to this old soldier crap once and for all! For others to interest me I must first find in myself the energy for such an interest. What binds me to others must grow out of what binds me to the most exuberant and demanding part of my will to live; not the other way round. It is always myself that I am looking for in other people; my enrichment, my realization. let everyone understand this and 'each for himself' taken to its ultimate conclusion will be transformed into 'all for each'. The freedom of one will be the freedom of all. A community which is not built on the demands of individuals and their dialectic can only reinforce the oppressive violence of power. The Other in whom I do not find myself is nothing but a thing, and altruism leads me to the love of things, to the love of my isolation.

Seen from the viewpoint of altruism, or of solidarity, that altruism of the left, the sentiment of equality is standing on its head. What is it but the common anguish of associates who are lonely together, humiliated, fucked up, beaten, deprived, contented together, the anguish of unattached particles, hoping to be joined together, not in reality, but in a mystical union, any union, that of the Nation or that of the Labour Movement, it doesn't matter which so long as it makes you feel like those drunken evenings when we're all pals together? Equality in the great family of man reeks of the incense of religious mystification. You need a blocked-up nose to miss the stink.

For myself, I recognize no equality except that which my will to live according to my desires recognizes in the will to live of others. Revolutionary equality will be indivisibly individual and collective.

\section{4}

The perspective of power has only one horizon: death. And life goes to this well of despair so often that in the end it falls in and drowns. Wherever the fresh water of life stagnates, the features of the drowned man reflect the faces of the living: the positive, looked at closely, turns out to be negative, the young are already old and everything we are building is already a ruin. In the realm of despair, lucidity blinds just as much as falsehood. We die of not knowing, struck from behind. In addition, the knowledge of the death that awaits us only increases the torture and brings on the agony. The disease of attrition that checks, shackles, forbids our actions, eats us away more surely than a cancer, but nothing spreads the disease like the acute consciousness of this attrition. I remain convinced that nothing could save a man who was continually asked: have you noticed the hand that, with all die respect, is killing you? To evaluate the effect of each tiny persecution, to estimate neurologically the weight of each constraint, would be enough to flood the strongest individual with a single feeling, the feeling of total and terrible powerlessness. The maggots of constraint are spawned in the very depths of the mind; nothing human can resist them.

Sometimes I feel as if power is making me like itself: a great energy on the point of collapsing, a rage powerless to break out, a desire for wholeness suddenly petrified. An impotent order survives only by ensuring the impotence of its slaves: Franco and Batista demonstrated this fact with 
brio when they castrated captured revolutionaries. The regimes jokingly known as 'democratic' merely humanize castration. At first sight, to bring an old age prematurely seems less feudal than the use of the knife and ligature. But only at first sight: for as soon as a lucid mind has understood that impotence now strikes through the mind itself, we might as well pack up and go home.

There is a kind of understanding which is allowed by power because it serves its purposes. To borrow one's lucidity from the light of power is to illuminate the darkness of despair, to feed truth on lies. Thus the aesthetic stage is defined: either death against power, or death in power: Arthur Cravan and Jacques Vaché on one side, the S.S, the mercenary and the hired killer on the other. For them death is a logical and natural end, the final confirmation of a permanent state of affairs, the last dot of a lifeline on which, in the end, nothing was written. Everyone who does not resist the almost universal attraction of power meets the same fate: the stupid and confused always, very often the intelligent too. The same rift is to be found in Drieu and Jacques Rigaux, but they came down on different sides: the impotence of the first was moulded in submission and servility, the revolt of the second smashed itself prematurely against the impossible. The despair of consciousness makes the murderers of Order, the consciousness of despair makes the murderers of Disorder. The fall back into conformity of the so-called anarchists of the right is caused by the same gravitational pull as the fall of damned archangels into the iron jaws of suffering. The rattles of counter-revolution echo through the vaults of despair.

Suffering is the pain of constraints. An atom of pure delight, no matter how small, will hold it at bay. To work on the side of delight and authentic festivity can hardly be distinguished from preparing for a general insurrection.

In our times, people are invited to take part in a gigantic hunt with myths and received ideas as quarry, but for safety's sake they are sent without weapons, or, worse, with paper weapons of pure speculation, into the swamp of constraints where they finally stick. Perhaps we will get our first taste of delight by pushing the ideologists of demystification in front of us, so that we can see how they make out, and either take advantage of their exploits or advance over their bodies.

As Rosanov says, men are crushed under the wardrobe. Without lifting up the wardrobe it is impossible to deliver whole peoples from their endless and unbearable suffering. It is terrible that even one man should be crushed under such a weight: to want to breathe, and not to be able to. The wardrobe rests on everybody, and everyone gets his inalienable share of suffering. And everybody tries to lift up the wardrobe, but not with the same conviction, not with the same energy. A curious groaning civilization.

Thinkers ask themselves: "What? Men under the wardrobe? However did they get there?" All the same, they got there. And if someone comes along and proves in the name of objectivity that the burden can never be removed, each of his words adds to the weight of the wardrobe, that object which he means to describe with the universality of his 'objective consciousness'. And the whole Christian spirit is there, fondling suffering like a good dog and handing out photographs of crushed but smiling men. "The rationality of the wardrobe is always the best", proclaim the thousands of books published every day to be stacked in the wardrobe. And all the while everyone wants to breathe and no-one can breathe, and many say "We will breathe later", and most do not die, because they are already dead.

It is now or never. 


\section{Chapter 5. The Decline and Fall of Work}

The duty to produce alienates the passion for creation. Productive labour is part and parcel of the technology of law and order. The working day grows shorter as the empire of conditioning extends.

In an industrial society which confuses work and productivity, the necessity of producing has always been an enemy of the desire to create. What spark of humanity, of a possible creativity, can remain alive in a being dragged out of sleep at six every morning, jolted about in suburban trains, deafened by the racket of machinery, bleached and steamed by meaningless sounds and gestures, spun dry by statistical controls, and tossed out at the end of the day into the entrance halls of railway stations, those cathedrals of departure for the hell of weekdays and the nugatory paradise of weekends, where the crowd communes in weariness and boredom? From adolescence to retirement each 24-hour cycle repeats the same shattering bombardment, like bullets hitting a window: mechanical repetition, time-which-is-money, submission to bosses, boredom, exhaustion. From the butchering of youth's energy to the gaping wound of old age, life cracks in every direction under the blows of forced labour. Never before has a civilization reached such a degree of contempt for life; never before has a generation, drowned in mortification, felt such a rage to live. The same people who are murdered slowly in the mechanized slaughterhouses of work are also arguing, singing, drinking, dancing, making love, holding the streets, picking up weapons and inventing a new poetry. Already the front against forced labour is being formed; its gestures of refusal are moulding the consciousness of the future. Every call for productivity in the conditions chosen by capitalist and Soviet economy is a call to slavery.

The necessity of production is so easily proved that any hack philosopher of industrialism can fill ten books with it. Unfortunately for these neo-economist thinkers, these proofs belong to the nineteenth century, a time when the misery of the working classes made the right to work the counterpart of the right to be a slave, claimed at the dawn of time by prisoners about to be massacred. Above all it was a question of surviving, of not disappearing physically. The imperatives of production are the imperatives of survival; from now on, people want to live, not just to survive.

The tripalium is an instrument of torture. Labor means 'suffering'. We are unwise to forget the origin of the words 'travail' and 'labour'. At least the nobility never forgot their own dignity and the indignity which marked their bondsmen. The aristocratic contempt for work reflected the master's contempt for the dominated classes; work was the expiation to which they were condemned to all eternity by the divine decree which had willed them, for impenetrable reasons, to be inferior. Work took its place among the sanctions of Providence as the punishment for poverty, and because it was the means to a future salvation such a punishment could take on the attributes of pleasure. basically, work was less important than submission.

The bourgeoisie does not dominate, it exploits. It does not need to be master, it prefers to use. Why has nobody seen that the principle of productivity simply replaced the principle of feudal authority? Why has nobody wanted to understand? 
Is it because work ameliorates the human condition and saves the poor, at least in illusion, from eternal damnation? Undoubtedly, but today it seems that the carrot of happier tomorrows has smoothly replaced the carrot of salvation in the next world. In both cases the present is always under the heel of oppression.

Is it because it transforms nature? Yes, but what can I do with a nature ordered in terms of profit and loss, in a world where the inflation of techniques conceals the deflation of the usevalue of life? Besides, just as the sexual act is not intended to procreate, but makes children by accident, organized labour transforms the surface of continents as a by-product, not a purpose. Work to transform the world? Tell me another. The world is being transformed in the direction prescribed by the existence of forced labour; which is why it is being transformed so badly.

Perhaps man realizes himself in his forced labour? In the nineteenth century the concept of work retained a vestige of the notion of creativity. Zola describes a nailsmiths' contest in which the workers competed in the perfection of their tiny masterpiece. Love of the trade and the vitality of an already smothered creativity incontestably helped man to bear ten or fifteen hours which nobody could have stood if some kind of pleasure had not slipped into it. The survival of the craft conception allowed each worker to contrive a precarious comfort in the hell of the factory. But Taylorism dealt the death-blow to a mentality which had been carefully fostered by archaic capitalism. It is useless to expect even a caricature of creativity from the conveyor-belt. Nowadays ambition and the love of the job well done are the indelible mark of defeat and the most mindless submission. Which is why, wherever submission is demanded, the old ideological fart wends its way, from the Arbeit Macht Frei of the concentration camps to the homilies of Henry Ford and Mao Tse-tung.

So what is the function of forced labour? The myth of power exercised jointly by the master and God drew its coercive force from the unity of the feudal system. Destroying the unitary myth, the power of the bourgeoisie inaugurated, under the flag of crisis, the reign of ideologies, which can never attain, separately or together, a fraction of the efficacy of myth. The dictatorship of productive work stepped into the breech. It's mission is physically to weaken the majority of men, collectively to castrate and stupefy them in order to make them receptive to the least pregnant, least virile, most senile ideologies in the entire history of falsehood.

Most of the proletariat at the beginning of the nineteenth century had been physically enervated, systematically broken by the torture of the workshop. Revolts came from artisans, from privileged or unemployed groups, not from workers shattered by fifteen hours of labour. Isn't it disturbing that the reduction of working time came just when the spectacular ideological miscellany produced by consumer society was beginning effectively to replace the feudal myths destroyed by the young bourgeoisie? (People really have worked for a refrigerator, a car, a television set. Many still do, 'invited' as they are to consume the passivity and empty time that the 'necessity' of production 'offers' them.)

Statistics published in 1938 indicated that the use of the most modern technology then available would reduce necessary working time to three hours a day. Not only are we a long way off with our seven hours, but after wearing out generations of workers by promising them the happiness which is sold today on the installment plan, the bourgeoisie (and its Soviet equivalent) pursue man's destruction outside the workshop. Tomorrow they will deck out their five hours of necessary wear and tear with a time of 'creativity' which will grow just as fast as they can fill it with the impossibility of creating anything (the famous 'leisure explosion'). 
It has been quite correctly written: "China faces gigantic economic problems; for her, productivity is a matter of life and death." Nobody would dream of denying it. What seems important to me is not the economic imperatives, but the manner of responding to them. The Red Army in 1917 was a new kind of organization. The Red Army in 1960 is an army such as is found in capitalist countries. Circumstances have shown that its effectiveness has been far below the potential of a revolutionary militia. In the same way, the planned Chinese economy, by refusing to allow federated groups to organize their work autonomously, condemns itself to become another example of the perfected form of capitalism called socialism. Has anyone bothered to study the modes of work of primitive peoples, the importance of play and creativity, the incredible yield obtained by methods which the application of modern technology would make a hundred times more efficient? Obviously not. Every appeal for productivity comes from above. But only creativity is spontaneously rich. It is not from 'productivity' that a full life is to be expected, it is not 'productivity' that will produce an enthusiastic collective response to economic needs. But what can we say when we know how the cult of work is honoured from Cuba to China, and how well the virtuous pages of Guizot would sound in a May Day speech?

To the extent that automation and cybernetics foreshadow the massive replacement of workers by mechanical slaves, forced labour is revealed as belonging purely to the barbaric practices needed to maintain order. Thus power manufactures the dose of fatigue necessary for the passive assimilation of its televised diktats. What carrot is worth working for, after this? The game is up; there is nothing to lose anymore, not even an illusion. The organization of work and the organization of leisure are the blades of the castrating shears whose job is to improve the race of fawning dogs. One day, will we see strikers, demanding automation and a ten-hour week, choosing, instead of picketing, to make love in the factories, the offices and the culture centres? Only the planners, the managers, the union bosses and the sociologists would be surprised and worried. Not without reason; after all, their skin is at stake. 


\section{Chapter 6. Decompression and the Third Force}

Until now, tyranny has merely changed hands. In their common respect for rulers, antagonistic powers have always fostered the seeds of their future coexistence. (When the leader of the game takes the power of a Leader, the revolution dies with the revolutionaries.) Unresolved antagonisms fester, hiding real contradictions. Decompression is the permanent control of both antagonists by the ruling class. The third force radicalizes contradictions and leads to their supersession, in the name of individual freedom and against all forms of constraint. Power has no option but to smash or incorporate the third force without admitting its existence.

To sum up. Millions of men lived in a huge building with no doors or windows. The feeble light of countless oil lamps competed with the unchanging darkness. As had been the custom since remotest antiquity, the upkeep of the lamps was the duty of the poor, so that the flow of oil followed the alternation of revolt and pacification. One day a general insurrection broke out, the most violent that this people had ever known. Its leaders demanded a fair allotment of the costs of lighting; a large number of revolutionaries said that what they considered a public utility should be free; a few extremists went so far as to clamour for the destruction of the building, which they claimed was unhealthy, even unfit for human habitation. As usual, the more reasonable combatants found themselves helpless before the violence of the conflict. During a particularly lively clash with the forces of order, a stray bullet pierced the outer wall, leaving a crack through which daylight streamed in. After a moment of stupor, this flood of light was greeted with cries of victory. The solution had been found: all they had to do was to make some more holes. The lamps were thrown away or put in museums, and power fell to the window makers. The partisans of radical destruction were forgotten, and even their discreet liquidation, it seems, went almost unnoticed. (Everyone was arguing about the number and position of the windows.) Then, a century or two later, their names were remembered, when the people, that eternal malcontent, had grown accustomed to plate-glass windows, and took to asking extravagant questions. "To drag out our days in a greenhouse, is that living?” they asked.

The consciousness of our time oscillates between that of the walled-up man and that of the prisoner. For the individual, the oscillation takes the place of freedom; like a condemned man, he paces up and down between the blank wall of his cell and the barred window that represents the possibility of escape. If somebody knocks a hole in the cellar of isolation, hope filters in with the light. The good behaviour of the prisoner depends on the hope of escape which prisons foster. On the other hand, when he is trapped by a wall with no windows, a man can only feel the desperate rage to knock it down or break his head against it, which can only be seen as unfortunate from the point of view of efficient social organization (even if the suicide doesn't have the happy idea 
of going to his death in the style of an oriental price, immolating all his slaves: judges, bishops, generals, policemen, psychiatrists, philosophers, managers, specialists, planners...)

The man who is walled up alive has nothing to lose; the prisoner still has hope. Hope is the leash of submission. When power's boiler is in danger of exploding, it uses its safety-valve to lower the pressure. It seems to change; in fact it only adapts itself and resolves its difficulties.

There is no authority which does not see, rising against it, an authority which is similar but which passes for its opposite. But nothing is more dangerous for the principle of hierarchical government than the merciless confrontation of two powers driven by a rage for total annihilation. In such a conflict, the tidal wave of fanaticism carries away the most stable values; no-mans-land eats up the whole map, establishing everywhere the inter-regnum of "nothing is true. everything is permitted". History, however, offers not one example of a titanic conflict which has not opportunely defused and turned into a comic-opera battle. What is the source of this decompression? The agreement on matters of principle which is implicitly reached by the warring powers.

The hierarchical principle remains common to the fanatics of both sides: opposite the capitalism of Lloyd George and Krupp appears the anticapitalism of Lenin and Trotsky. From the mirrors of the masters of the present the masters of the future are already smiling back. Heinrich Heine writes:

\section{Lächelnd scheidet der Tyran \\ Denn er weiss, nach seinem Tode \\ Wechselt Willkür nur die Hände \\ Und die Knechtschaft hat kein Ende.}

The tyrant dies smiling; for he knows that after his death tyranny will merely change hands, and slavery will never end. Bosses differ according to their modes of domination, but they are still bosses, owners of a power exercised as a private right. (Lenin's greatness has to do with his romantic refusal to assume the position of absolute master implied by his ultra-hierarchical organization of the Bolshevik party; and it is to this greatness also that the workers' movement is indebted for Kronstadt, Budapest and batiuchka Stalin.)

From this moment, the point of contact between the two powers becomes the point of decompression. To identify the enemy with Evil and crown one's own side with the halo of Good has the strategic advantage of ensuring unity of action by canalising the energy of the combatants. But this manoeuvre demands the annihilation of the enemy. Moderates hesitate before such a prospect; for the radical destruction of the enemy would include the destruction of what their own side has in common with the enemy. The logic of Bolshevism demanded the heads of the leaders of social-democracy; the latter hastily sold out, and they did so precisely because they were leaders. The logic of anarchism demanded the liquidation of Bolshevik power; the latter rapidly crushed them, and did so inasmuch as it was hierarchical power. The same predictable sequence of betrayals threw Durrutti's anarchists before the united guns of republicans, socialists and Stalinists.

As soon as the leader of the game turns into a Leader. the principle of hierarchy is saved, and the Revolution sits down to preside over the execution of the revolutionaries. We must never forget that the revolutionary project belongs to the masses alone; leaders help it, Leaders betray it. To begin with, the real struggle takes place between the leader of the game and the Leader. 
The professional revolutionary measures the state of his forces in quantitative terms, just as any soldier judges an officer's rank by the number of men under his command. The leaders of socalled insurrectionary parties dismiss the qualitative in favour of a quantitative expertise. had the 'reds' been blessed with half a million more men with modern weapons, the Spanish revolution would still have been lost. It died under the heels of the people's commissars. The speeches of La Pasionaria already sounded like funeral orations; pathetic whining drowned the language of deeds, the spirit of the collectives of Aragon - the spirit of a radical minority resolved to sever with a single stroke all the heads of the hydra, not just its fascist head.

Never, and for good reason, has an absolute confrontation been carried through. So far the last fight has only had false starts. Everything must be resumed from scratch. History's only justification is to help us do it.

Under the process of decompression, antagonists who seemed irreconcilable at first sight grow old together, become frozen in purely formal opposition, lose their substance, neutralize and moulder into each other. Who would recognize the Bolshevik with his knife between his teeth in the Gagarinism of doting Moscow? Today, by the grace of the Ïcumenical miracle, the slogan "Workers of the World, unite" celebrates the union of the world's bosses. A touching scene. The common element in the antagonism, the seed of power, which a radical struggle would have rooted out, has grown up to reconcile the estranged brothers.

Is it as simple as this? Of course not; the farce would lose its entertainment value. On the international stage, those two old hams, capitalism and anticapitalism, carry on their lovers' banter. How the spectators tremble when they begin to quarrel, how they stamp with glee when peace blesses the loving couple! Is interest flagging? A brick is added to the Berlin wall; the bloodthirsty Mao gnashes his paper teeth, while in the background a choir of little Chinese nitwits sings paeons to fatherland, family and work. Patched up like this, the old melodrama is ready to hit the road. The ideological spectacle keeps up with the times by bringing out harmless plastic antagonisms; are you for or against Brigitte Bardot, the Beatles, mini-cars, hippies, nationalization, spaghetti, old people, the TUC, mini-skirts, pop art, thermonuclear war, hitch-hiking? There is no one who is not accosted at every moment of the day by posters, news flashes, stereotypes, summoned to take sides over each of the prefabricated trifles that conscientiously stop up all the sources of everyday creativity. In the hands of power these particles of antagonism are moulded into a magnetic ring whose function is to make everybody lose their bearings, to pull everyone out of himself and to scramble lines of force.

Decompression is simply the control of antagonisms by power. The opposition of two terms is given its real meaning by the introduction of a third. As long as there are only two equal and opposite polarities, they neutralize each other, since each is defined by the other; as it is impossible to choose between them, we are led into the domain of tolerance and relativity which is so dear to the bourgeoisie. One can well understand the importance for the apostolic hierarchy of the dispute between Manicheism and Trinitarianism! In a merciless confrontation between God and Satan, what would have been left of ecclesiastical authority? Nothing, as the millenarian crises demonstrated. That is why the secular arm carried out its holy offices, and the pyres crackled for the mystics of God or the devil, those overbold theologians who questioned the principle of Three in One. The temporal masters of Christianity were resolved that only they should be entitled to 
treat of the difference between the master of Good and the master of Evil. They were the great intermediaries through which the choice of one side or the other had to pass; they controlled the paths to salvation and damnation, and this control was more important to them than salvation and damnation themselves. On earth they proclaimed themselves judges without appeal, since they had also decided to be the judged in an afterlife whose laws they had invented.

The Christian myth defused the bitter Manichean conflict by offering to the believer the possibility of individual salvation; this was the breach opened up by the Poor Bugger of Nazareth. Thus man escaped the rigours of a confrontation which necessarily led to the destruction of values, to nihilism. But the same stroke denied him the opportunity to reconquer himself by means of a general upheaval, the chance of taking his place in the universe by chasing out the gods and their slavemasters. Therefore, the movement of decompression appears to have the function of shackling man's most irreducible desire, the desire to be completely himself.

In all conflicts between opposing sides, an irrepressible upsurge of individual desires takes place and often reaches a threatening intensity. To this extent we are justified in talking of a third force. From the individual's point of view, the third force is what the force of decompression is from the point of view of power. The small chance of every struggle, it radicalizes insurrections, denounces false problems, threatens power in its very structure. It is what Brecht was referring to in one of his Keuner stories: "When a proletarian was brought to court and asked if he wished to take the oath in the ecclesiastical or the lay form, he replied 'I'm out of work."' The third force does not hope for the withering away of constraints, but aims to supersede them. Prematurely crushed or incorporated, it becomes by inversion a force of decompression. Thus, the salvation of the soul is nothing but the will to live, incorporated through myth, mediated, emptied of its real content. On the other hand, their peremptory demand for a full life explains the hatred incurred by certain gnostic sects or by the Brethren of the Free Spirit. During the decline of Christianity, the struggle between Pascal and the Jesuits spotlighted the opposition between the reformist doctrine of individual salvation and compromise with heaven and the project of realizing God by the nihilist destruction of the world. And, once it had got rid of the dead wood of theology, the third force survived to inspire Babeuf's struggle against the million doré, the Marxist project of the complete man, the dreams of Fourier, the explosion of the Commune, and the violence of the anarchists.

Individualism, alcoholism, collectivism, activism... the variety of ideologies shows that there are a hundred ways of being on the side of power. There is only one way to be radical. The wall that must be knocked down is immense, but it has been cracked so many times that soon a single cry will be enough to bring it crashing to the ground. Let the formidable reality of the third force emerge at last from the mists of history, with all the individual passions that have fuelled the insurrections of the past! Soon we shall find that an energy is locked up in everyday life which can move mountains and abolish distances. The long revolution is preparing to write works in the ink of action whose unknown or nameless authors will flock to join Sade, Fourier, Babeuf, Marx, Lacenaire, Stirner, Lautréamont, L'hautier, Vaillant, Henry, Villa, Zapata, Makhno, the Communards, the insurrectionaries of Hamburg, Kiel, Kronstadt, Asturias - all those who have not yet played their last card in a game which we have only just joined: the great gamble whose stake is freedom. 


\section{Impossible Communication or Power As Universal Mediation}


In the realm of Power, mediation is the false necessity wherein people learn to lose themselves rationally. Mediation's power to alienate is now being reinforced, and also brought into question, by the dictatorship of consumption (seven), by the predominance of exchange over gift (eight), by cybernetisation (nine), and by the reign of the quantitative (ten). 


\section{Chapter 7. The Age of Happiness}

The contemporary welfare state belatedly provides the guarantees of survival which were demanded by the disinherited members of the production society of former days (1). Richness of survival entails the pauperisation of life (2). Purchasing power is licence to purchase power, to become an object in the order of things. The tendency is for both oppressor and oppressed to fall, albeit at different speeds, under one and the same dictatorship: the dictatorship of consumer goods (3).

1

The face of happiness vanished from art and literature as it began to be reproduced along endless walls and hoardings, offering to each particular passerby the universal image in which he is invited to recognize himself.

Three cheers for Adam Smith and Jeremy Bentham: happiness is not a myth! "The more we produce, the better we shall live," writes the humanist Fourastié, and another genius, general Eisenhower, takes up the refrain: "to save the economy, we must buy, buy anything." Production and consumption are the dugs of modern society. Thus suckled, humanity grows in strength and beauty: rising standards of living, all mod. cons, a choice of entertainments, culture for all, the comfort of your dreams. On the horizon of the Khrushchev report, the rosy dawn of Communism is breaking at last, a new era heralded by two revolutionary decrees: the abolition of taxes and free transport for all. Yes, the golden age is in sight; or rather within spitting distance.

In this upheaval one thing has disappeared: the proletariat. Where on earth can it be? Spirited away? Gone underground? Or has it been put in a museum? Sociologi disputant. We hear from some quarters that in the advanced industrial countries the proletariat no longer exists, what with all these stereograms, TV sets, slumberland mattresses, mini-cars, tower blocks and bingo halls. Others denounce this as a sleight of hand and indignantly point out a few remaining workers whose low wages and wretched conditions do undeniably evoke the $19^{\text {th }}$ century. "Backward sectors", comes the retort, "in the process of reabsorption". Can you deny that the direction of economic development is towards Sweden, Czechoslovakia, the welfare state, and not towards India?

The black curtain rises: the hunt is on for the starving, for the last of the proletarians. The prize goes to the one who sells him his car and his mixer, his bar and his home library; the one who teaches him to see himself in the leering hero of an advertisement that reassures him: "You smile when you smoke Cadets."

And happy, happy humanity so soon to receive the parcels which were redirected to them at such great cost by the rebels of the nineteenth century. The insurgents of Lyon and Fourmies have certainly proved luckier dead than alive. The millions of human beings who were shot, tortured, jailed, starved, treated like animals and made the objects of a conspiracy of ridicule can sleep in peace in their communal graves, for at least the struggle in which they died has enabled their descendants, isolated in their air-conditioned rooms, to believe on the strength of their daily dose 
of television that they are happy and free. The Communards went down, fighting to the last, so that you too could own a Philips hi-fi stereo system. A fine future, and one to realize all the dreams of the past, there is no doubt about it.

Only the present is left out of the reckoning. Ungrateful and uncouth, the younger generation doesn't want to know about this glorious past which is offered as a free gift to every consumer of Trotskyist-reformist ideology. They claim that to make demands means to make demands for the here and now. They recall that the meaning of past struggles is rooted in the present of the men who fought them, and that despite different historical conditions they themselves are living in the same present. In short, one might say that radical revolutionary currents are inspired by one unchanging project: the project of being a whole man, a will to live totally which Marx was the first to provide with scientific tactics. But these are pernicious theories which the holy churches of Christ and Stalin never miss a chance to condemn. More money, more fridges, more holy sacraments and more GNP, that's what is needed to satisfy our revolutionary appetites.

Are we condemned to the state of well-being? Peace-loving citizens will inevitably deplore the forms taken by the opposition to a programme which everybody agrees with, from Khrushchev to Schweitzer, from the Pope to Fidel Castro, from Aragon to the late Mr. Kennedy.

In December 1956, a thousand young people ran wild in the streets of Stockholm, setting fire to cars, smashing neon signs, tearing down hoardings and looting department stores. At Merlebach, during a strike called to force the mine-owners to bring up the bodies of seven miners killed by a cave-in, the workers set about the cars parked at the pit head. In January 1961, strikers in Liege burned down the Guillemins station and destroyed the offices of the newspaper La Meuse. Seaside resorts in England and Belgium were devastated by the combined efforts of hundreds of mods and rockers in March 1964. In Amsterdam (1966) the workers held the streets for several days. Not a month goes by without a wildcat strike which pits the workers against both employers and union bosses. Welfare State? The people of Watts have given their answer.

A Ford worker summed up his difference of opinion with the B.F.Skinners, Doxiadis', Lord Robenses, Norbert Weiners and other watchdogs of the future in the following terms: "Since 1936 I have been fighting for higher wages. My father before me fought for higher wages. I've got a TV, a fridge and a Cortina. If you ask me it's been a dog's life from start to finish.”

In action, as in words, the new poetry just doesn't get on with the Welfare State.

\section{2}

In the kingdom of consumption the citizen is king. A democratic monarchy: equality before consumption, fraternity in consumption, and freedom through consumption. The dictatorship of consumer goods has finally destroyed the barriers of blood, lineage and race; this would be good cause for celebration were it not that consumption, by its logic of things, forbids all qualitative difference and recognizes only differences of quantity between values and between men. The distance has not changed between those who possess a lot and those who possess a small but everincreasing amount; but the intermediate stages have multiplied, and have, so to speak, brought the two extremes, rulers and ruled, closer to the same centre of mediocrity. To be rich nowadays merely means to possess a large number of poor objects.

Consumer goods are tending to lose all use-value. Their nature is to be consumable at all costs. (Recall the recent vogue of the nothing-box in the USA: an object which cannot be used 
for anything at all.) And as General Eisenhower so candidly explained, the present economic system can only be rescued by turning man into a consumer, by identifying him with the largest possible number of consumable values, which is to say, non-values, or empty, fictitious, abstract values. After being “the most precious kind of capital”, in Stalin's happy phrase, man must now become the most valued of consumer goods. The stereotyped images of the star, the poor man, the communist, the murderer-for-love, the law-abiding-citizen, the rebel, the bourgeois, will replace man, putting in his place a system of multicopy categories arranged according to the irrefutable logic of robotisation. Already the idea of 'teenager' tends to define the buyer in conformity with the product he buys, to reduce his variety to a varied but limited range of objects in the shops, (Records, guitars, Levis...). You are no longer as old as you feel or as old as you look, but as old as what you buy. The time of production-society where 'time is money' will give way to the Time of consumption, measured in terms of products bought, worn out and thrown away: a Time of premature old age, which is the eternal youth of trees and stones.

The truth of the concept of immiseration has been demonstrated today not, as Marx expected, in the field of goods necessary for survival, since these, far from becoming scarce, have become more and more abundant; but rather in relation to survival itself, which is always the enemy of real life.

Affluence had seemed to promise to all men the Dolce Vita previously lived by the feudal aristocracy. But in the event affluence and its comforts are only the children of capitalist productivity, children doomed to age prematurely as soon as the marketing system has transformed them into mere objects of passive consumption. Work to survive, survive by consuming, survive to consume, the hellish cycle is complete. In the realm of economism, survival is both necessary and sufficient. This is the fundamental truth of bourgeois society. But it is also true that a historical period based on such an antihuman truth can only be a period of transition, an intermediate stage between the unenlightened life that was lived by the feudal masters and the life that will be constructed rationally and passionately by the masters without slaves. Only thirty years are left if we want to end the transitional period of slaves without masters before it has lasted two centuries.

\section{3}

With regard to everyday life, the bourgeois revolution looks more like a counter-revolution. The market in human values has rarely known such a collapse. The aristocratic life with its wealth of passions and adventures suffered the fate of a palace partitioned off into furnished rooms, gloomy bedsitters whose drabness is made even more unbearable by the sign outside which proclaims, like a challenge hurled at the Universe, that this is the age of freedom and well-being. From now on hatred gives way to contempt, love to cohabitation, the ridiculous to the stupid, passion to sentimentality, desire to envy, reason to calculation, the taste for life to the fear of death. The utterly contemptible morality of profit came to replace the utterly detestable morality of honour; the mysterious and perfectly ridiculous power of birth and blood gave way to the perfectly ubuesque power of money. The children of August $4^{\text {th }} 1789$ took bankers' orders and sales charts as their coats of arms; mystery was now enshrined in their ledgers.

Wherein lies the mystery of money? Clearly in that it represents a sum of beings and things that can be appropriated. The nobleman's coat of arms expresses God's choice and the real power 
exercised by his elect; money is only a sign of what might be acquired, it is a draft on power, a possible choice.

The feudal God, who appeared to be the basis of the social order, was really only its magnificent crowning excuse. Money, that odourless god of the bourgeois, is also a mediation; a social contract. It is a god swayed not by prayers or by promises but by science and specialist knowhow. Its mystery no longer lies in a dark and impenetrable totality but in the sum of an infinite number of partial certainties; no longer in the quality of lordship but in the number of marketable people and things (for example, what a hundred thousand pounds puts within the reach of its possessor).

In the economy of free-trade capitalism, dominated by imperatives of production, wealth alone confers power and honour. Master of the means of production and of labour power, it controls the development of productive forces and consumer goods and thus its owners have the pick of the myriad fruits of an infinite progress. However, as this capitalism transforms itself into its contrary, state-planned economy, the prestige of the capitalist playing the market with his millions fades away and with it the caricature of the pot-bellied, cigar-puffing merchant of human flesh. Today we have managers, who derive their power from their talent for organization; and already computers are doing them out of a job. Managers, of course, do get their monthly paychecks but do they do anything worthwhile with them? Can they enjoy making their salary signify the wealth of possible choices before them: building a Xanadou, keeping a harem, cultivating flower-children? When all possibilities of consumption are already organized, how can wealth preserve its representable value? Under the dictatorship of consumer goods, money melts away like a snowball in hell. Its significance passes to objects with more representational value, more tangible objects better adapted to the spectacle of the welfare state. Consumer goods are already encroaching on the power of money, because wrapped in ideology, they are the true signs of power. Before long its only remaining justification will be the quantity of objects and useless gadgets it enables one to acquire and throw away at an ever-accelerating pace; only the quantity and the pace matter, because mass-distribution automatically wipes out quality and rarity-appeal. From now on the ability to consume, faster and faster, great quantities of cars, alcohol, houses, TV-sets and girlfriends will show how far you've got up the hierarchical ladder. From the superiority of blood to the power of money, from the superiority of money to the power of the gadget, the nec plus ultra of Christian/socialist civilization: a civilization of prosaism and vulgar detail. A nice nest for Nietzsche's "little men".

Purchasing power is a license to purchase power. The old proletariat sold its labour power in order to subsist; what little leisure time it had was passed pleasantly enough in conversations, arguments, drinking, making love, wandering, celebrating and rioting. The new proletarian sells his labour power in order to consume. When he's not flogging himself to death to get promoted in the labour hierarchy, he's being persuaded to buy himself objects to distinguish himself in the social hierarchy. The ideology of consumption becomes the consumption of ideology. The cultural détente between east and west is not accidental! On the one hand, homo consomator buys a bottle of whisky and gets as a free gift the lie that accompanies it. On the other, Communist man buys ideology and gets as a free gift a bottle of vodka. Paradoxically, Soviet and capitalist regimes are taking a common path, the first thanks to their economy of production, the second thanks to their economy of consumption.

In the USSR, the surplus labour of the workers does not, strictly speaking, directly enrich their comrade the director of the enterprise. it simply strengthens his power as an organizer and a 
bureaucrat. His surplus-value is a surplus-value of power. (But this new-style surplus-value is nevertheless subject to the tendency for the rate of profit to fall. Marx's laws of economic life are confirmed today in the economy of life.) He earns it, not on the basis of money-capital, but on the basis of a primitive accumulation of confidence-capital gained by his docile absorption of ideological matter. The car and the dacha which are thrown in to reward his services to the Socialist Fatherland, to Output and the Cause, foretell a form of social organization in which money will indeed have disappeared, giving way to honorific distinctions of rank, a mandarinate of the biceps and of specialized thought. (Remember the special treatment given to Stakhanovites, to 'heroes of space' and scrapers of catgut and canvas.)

In capitalist countries, the material profit gained by the employer from both production and consumption is still distinct from the ideological profit which the employer is no longer alone in deriving from the organization of consumption. This is all that prevents us from reducing the difference between manager and worker to the difference between a new Jaguar every year and a mini lovingly maintained for five. But we must recognize that the tendency is towards planning, and planning tends to quantify social differences in terms of the ability to consume and to make others consume. With the differences growing in number and shrinking in significance, the real differences between rich and poor is diminishing, and mankind is levelled into mere variations on poverty. The culmination of the process would be a cybernetic society composed of specialists ranked hierarchically according to their aptitude for consuming and making others consume the doses of power necessary for the functioning of a gigantic social computer of which they themselves would be simultaneously the programme and the printout. A society of exploited exploiters where some slaves are more equal than others.

There remains the third world. There remain the old forms of oppression. That the serfs of the latifundia should be the contemporaries of the new proletariat seems to me a perfect formula for the explosive mixture from which the total revolution will be born. Who would dare to suppose that the South American Indians will be satisfied with land reform and lay down their arms when the best-paid workers in Europe are demanding a radical change in their way of life? From now on, the revolt against the State of Well-Being sets the minimum demands for world revolution. You can choose to forget this, but you forget it at your peril... as Saint-Just said, those who make a revolution by halves do nothing but dig their own graves. 


\section{Chapter 8. Exchange and Gift}

The nobility and the proletariat conceive human relationships on the model of giving, but the proletarian way of giving supersedes the feudal gift. The bourgeoisie, the class of exchange, is the lever which enables the feudal project to be overthrown and superseded in the long revolution (1). History is the continuous transformation of natural alienation into social alienation, and the continuous strengthening of a contradictory movement of opposition which will overcome all alienation and end history. The historical struggle against natural alienation transforms natural alienation into social alienation, but the movement of historical disalienation eventually attacks social alienation itself and reveals that it is based on magic. This magic has to do with privative appropriation. It is expressed through sacrifice. Sacrifice is the archaic form of exchange. The extreme quantification of exchange reduces man to an object. From this rock bottom a new type of human relationship, involving neither exchange nor sacrifice, can be born (2).

\section{1}

The bourgeoisie administers a precarious and none-too-glorious interregnum between the sacred hierarchy of feudalism and the anarchic order of future classless societies. The bourgeois no-man's-land of exchange is the uninhabitable region separating the old, unhealthy pleasure of giving oneself, in which the aristocrats indulged, and the pleasure of giving through love of oneself, which the new generations of proletarians are little by little beginning to discover.

'Fair exchange' is the favourite absurdity of capitalism and its essentially similar competitors. The USSR 'offers' its hospitals and technicians, just as the USA 'offers' its investments and good offices, and supermarkets 'offer' 'free gifts'.

But the fact is that the meaning of giving has been rooted out from our minds, feelings and actions. Remember Breton and his friends offering roses to the pretty girls on the Boulevard Poissoniere, and immediately arousing the suspicion and hostility of the public.

The infection of human relations by exchange and bargaining is plainly linked to the existence of the bourgeoisie. The fact that exchange persists in a part of the world where it is claimed that there is a classless society suggests that the shadow of the bourgeoisie continues to rule under the red flag. Especially as the pleasure of giving, which appears in all industrial societies, defines very clearly the frontier between the world of calculation and the world of exuberance, of festivity. This style of giving has nothing to do with the prestige-gift practiced by the nobility, hopelessly imprisoned by the notion of sacrifice. The proletariat really does carry the project of human fullness, the project of total life: a project in which the aristocracy had failed, albeit failed magnificently. But let's give the devil his due: it is through the historical presence and mediation of the bourgeoisie that such a future becomes accessible to the proletariat. Is it not thanks to the technical progress and the productive forces developed by capitalism that the proletariat is in a position to realize, through the scientifically elaborated project of a new society, the egalitarian visions, the dreams of omnipotence and the desire to live without dead time? Today everything 
confirms the mission, or rather the historical opportunity of the proletariat: the destruction and supersession of feudalism. And it will do it by trampling underfoot the bourgeoisie, which is doomed to represent merely a transitional period in the development of man, albeit a transitional period without which the superseding of the feudal project would have been inconceivable: an essential stage, then, which created the lever without which unitary power would never have been overthrown, and above all could never have been transformed and corrected according to the project of the whole man. The invention of God shows that unitary power was already a world for the whole man, but for a whole man standing on his head. All that was required was to turn it right side up.

No liberation is possible this side of economics; in the world defined by economics there is only a hypothetical economics of survival. With these two truths the bourgeoisie is spurring mankind on towards the supersession of economics, towards a point beyond history. So the bourgeoisie is doing an even greater service than that of putting technology at the service of poetry. Its greatest day will be the day it disappears.

\section{2}

Exchange is linked to the survival of primitive hordes in the same way as privative appropriation; both together constitute the fundamental axiom on which the history of mankind has been built up to the present day.

When the first men found that it gave them more security in the face of a hostile nature, the formation of hunting territories laid the foundations of a social organization which has imprisoned us ever since. (Cf.Raoul and Laura Makarius: Totem et exagomie.) Primitive man's unity with nature is essentially magical. Man only really separates himself from nature by transforming it through technology, and as he transforms it he disenchants it. But the use of technology is determined by social organization. The birth of society coincides with the invention of the tool. More: organization itself is the first coherent technique of struggle against nature. Social organization - hierarchical, since it is based on private appropriation - gradually destroys the magical bond between man and nature, but it preserves the magic for its own use: it creates between itself and mankind a mythical unity modelled on the original participation in the mystery of nature. Framed by the 'natural' relations of prehistoric man, social organization slowly dissolves this frame that defines and imprisons it. From this point of view, history is just the transformation of natural alienation into social alienation: a process of disalienation becomes a process of social alienation, a movement of liberation only produces new chains; until the will for human liberation launches a direct attack upon the whole collection of paralyzing mechanisms, that is on the social organization based on privative appropriation. This is the movement of disalienation which will undo history and realize it in new modes of life.

Effectively, the bourgeoisie's accession to power represents man's victory over natural forces. But as soon as this happens, hierarchical social organization, which was born out of the struggle against hunger, sickness, discomfort... loses its justification, and can no longer escape taking full responsibility for the malaise of industrial civilizations. Today men no longer blame their sufferings on the hostility of nature, but on the tyranny of a perfectly inadequate and perfectly anachronistic form of society. When it destroyed the magical power of the feudal lords, the bourgeoisie pronounced the death sentence on the magic of hierarchical power itself. The proletariat 
will carry out this sentence. What the bourgeoisie began by historical processes will now be finished off in opposition to its own narrow conception of history. But it will still be a historical struggle, a class struggle which will realize history.

The hierarchical principle is the magic spell that has blocked the path of men in their historical struggles for freedom. From now on, no revolution will be worthy of the name if it does not involve, at the very least, the radical elimination of all hierarchy.

As soon as the members of a horde mark out a hunting territory and claim private ownership of it, they find themselves confronted by a hostility which is no longer the hostility of wild animals, weather, inhospitable regions, or sickness, but that of human groups who are excluded from the hunting-grounds. Man's genius found a way out of the animal dilemma: destroy the rival group or be destroyed by it. This way was through treaties, contracts and exchanges, which are the basis of primitive communities. Between the period of nomadic food-gathering hordes and that of agricultural societies, the survival of clans required a triple exchange: exchange of women, exchange of food and exchange of blood. Magical thinking provides this operation with a supreme controller, a master of exchanges, a power beyond and above the contracting parties. The birth of the gods coincides with the twin birth of sacred myth and hierarchical power.

Of course this exchange is never of equal benefit to both clans. The problem is always to ensure the neutrality of the excluded clan without actually letting it into the hunting territory. And agricultural societies refined these tactics. The excluded class, who were tenants before they became slaves, enter the landowning group not as landowners, but as their degraded reflection (the famous myth of the Fall), the mediation between the land and its masters. Why do they submit? Because of the coherent hold over them exercised by the myth - although it's not the deliberate intention of the masters (that would be to credit them with a rationality which was still foreign to them). This myth conceals the cunning of exchange, the imbalance in the sacrifice which each side agrees to make. The excluded class really sacrifice an important part of their life to the landowner: they accept his authority and work for him. The master mythically sacrifices his authority and his power as landowner to the dominated class: he is ready to pay for the safety of his people. God is the underwriter of the transaction and the defender of the myth. He punishes those who break the contract, while those who keep it he rewards with power: mythical power for those who sacrifice themselves in reality, real power for those who sacrifice themselves in myth. History and mythology show that the master could go as far as to sacrifice his life to the mythical principle. The fact that he payed the price of the alienation which he imposed on others reinforced the master's divine character. But it seems that a make-believe execution, or one in which he was replaced by a deputy, soon released the master from such a hard bargain. When the Christian God delegated his son to the world, he gave generations of bosses a perfect model by which to authenticate their own sacrifice.

Sacrifice is the archaic form of exchange. It is a magical exchange, unquantified, irrational. it dominated human relationships, including commercial relationships, until merchant capitalism and its money-the-measure-of-all-things had carved out such a large area in the world of slaves, serfs and burghers that the economy could appear as a particular zone, a domain separated from life. When money appears, the element of exchange in the feudal gift begins to win out. The sacrifice-gift, the potlatch - that exchange-game of loser-takes-all in which the size of 
the sacrifice determines the prestige of the giver - could hardly find a place in a rationalized exchange economy. Forced out of the sectors dominated by economic imperatives, it finds itself reincarnated in values such as hospitality, friendship and love: refuges doomed to disappear as the dictatorship of quantified exchange (market value) colonises everyday life and turns it into a market.

Merchant and industrial capitalism accelerated the quantification of exchange. The feudal gift was rationalized according to the rigorous model of commerce. The game of exchange became a matter of calculation. The playful Roman promise to sacrifice a cock to the gods in exchange for a peaceful voyage remained outside the grasp of commercial measurement because of the disparity of the things that were exchanged. And we can well imagine that the age in which a man like Fourquet could ruin himself in order to shine more brightly in the eyes of his contemporaries produced a poetry which has disappeared from our times, which take as their model of a human relationship the exchange of 35p for an 8oz. steak.

And so sacrifice came to be quantified, rationalized, measured out and quoted on the stock exchange. But what is left of the magic of sacrifice in a world of market values? And what is left of the magic of power, the sacred terror that impels the model employee to tip his hat respectfully to the boss? In a society where the quantity of gadgets and ideologies produced represents the quantity of power consumed, exercised and used up, magical relationships evaporate, leaving hierarchical power exposed to the full blast of opposition. When the last bastion falls, it will be either the end of a world or the end of the world. It's up to us to knock it down before it falls down by itself and drags us all with it.

Rigorously quantified, first by money and then by what you might call 'sociometric units of power', exchange pollutes all our relationships, all our feelings, all our thoughts. Where exchange is dominant, only things are left: a world of thing-men plugged into the organization charts of the computer freaks: the world of reification. But on the other hand it also gives us the chance radically to restructure our styles of life and thought. A rock bottom from which everything can start again.

The feudal mind seemed to conceive the gift as a sort of haughty refusal to exchange, a will to deny interchangeability. This refusal went with their contempt for money and common measurement. Of course, sacrifice excludes pure giving; but there was often so much room for play, humanity and gratuitous gestures that inhumanity, religion and seriousness could pass for accessories to such preoccupations as war, love, friendship, or hospitality.

By giving themselves, the nobility united their power with the totality of cosmic forces and claimed control over the totality which myth had made sacred. The bourgeoisie exchanged being for having and lost the mythical unity of being and the world: the totality fell into fragments. Semi-rational exchange in production implicitly makes a creativity that is reduced to labourpower equal in value to its hourly wage. Semi-rational exchange in consumption implicitly makes consumer-experience (life reduced to the activity of consumption) equal in value to an amount of power which indicates the consumer's position in the hierarchical organization chart. The sacrifice of the master is followed by the last stage of sacrifice, the sacrifice of the specialist.

In order to consume, the specialist makes others consume according to a cybernetic programme whose hyperrationality of exchange will abolish sacrifice... and man. If pure exchange 
ever comes to regulate the modes of existence of the robot-citizens of the cybernetic democracy, sacrifice will cease to exist. Objects need no justification to make them obedient. Sacrifice forms no part of the programme of machines, or of the antagonistic project, the project of the whole man.

The crumbling away of human values under the influence of exchange mechanisms leads to the crumbling of exchange itself. The insufficiency of the feudal gift means that new human relationships must be built on the principle of pure giving. We must rediscover the pleasure of giving: giving because you have so much. What beautiful and priceless potlatches the affluent society will see - whether it likes it or not! - when the exuberance of the younger generation discovers the pure gift. The growing passion for stealing books, clothes, food, weapons or jewelry simply for the pleasure of giving them away gives us a glimpse of what the will to live has in store for consumer society.

Prefabricated needs are confronted with the unitary need for a new style of life. Art, the economics of experience, has been absorbed by the market. Desires and dreams work for Madison Avenue now. Everyday life has crumbled into a series of moments as interchangeable as the gadgets which occupy them: mixers, stereograms, contraceptives, euphorimeters, sleeping pills. Everywhere equal particles vibrate in the uniform light of power. Equality, justice. Exchange of nothings, restrictions and prohibitions. Nothing moving, only dead time passing.

We will have to renew our acquaintance with the feudal imperfection, not in order to make it perfect but in order to supersede it. We will have to rediscover the harmony of unitary society and liberate it from the divine phantom and the sacred hierarchy. The new innocence is not so far removed from the ordeals and judgments of God: the inequality of blood is closer to the equality of free individuals, irreducible to one another, than bourgeois equality is. The cramped style of the nobility is only a crude sketch of the grand style which will be invented by masters without slaves. But what a world is trapped between this style of life and the mere way of living on, surviving, which ravages so many existences in our time! 


\section{Chapter 9. Technology and Its Mediated Use}

Contrary to the interests of those who control its use, technology tends to disenchant the world. Mass consumption society strips gadgets of any magical value. Similarly, organisation (a technique for handling new techniques) robs new productive forces of their subversive appeal and their power of disruption. Organisation thus stands revealed as nothing but the pure organisation of authority (1). Alienated mediations make man weaker as they become indispensible. A social mask disguises people and things. In the present stage of privative appropriation, this mask transforms its wearers into dead things, commodities. Nature no longer exists. To rediscover nature means to reinvent it as a worthwhile adversary by constructing new social relationships. With the expansion of material equipment, the old hierarchical society is bursting at the seams (2)

1

The same bankruptcy is evident in non-industrial civilisations, where people are still dying of starvation, and automated civilisations, where people are already dying od boredom. Every paradise is artificial. The life of a Trobriand islander, rich in spite of ritual and taboo, is at the mercy of a smallpox epidemic; the life of an ordinary Swede, poor in spite of his comforts, is at the mercy of suicide and survival sickness.

Rousseauism and pastoral idylls accompany the first throbbings of the industrial machine. The ideology of progress, as one finds it in Condorcet or Adam Smith, emerged from the old myth of the Four Ages. With the age of iron leading into the golden age, it seemed 'natural' that progress should fulfil itself as a return: a return to the state of innocence before the Fall.

The belief in the magical power of technology goes hand in hand with its opposite, the movement of disenchantment. The machine is the model of the intelligible. There is no mystery, nothing obscure in its drive-belts, cogs and gears; it can all be explained perfectly. But the machine is also the miracle that is to transport man into the realms of happiness and freedom. Besides, this ambiguity is useful to its masters: the old con about happy tomorrows and the green grass over the hill operates at various levels to justify the rational exploitation of men today. Thus it is not the logic of disenchantment that shakes people's faith in progress so much as the inhuman use of technical potential, the way that its mystical justification begins to grate. While the labouring classes and the underdeveloped peoples still offered the spectacle of their slowly decreasing material poverty, the enthusiasm for progress still drew ample nourishment from the troughs of liberal ideology and its extension, socialism. But, a century after the spontaneous demystification of the Lyons workers, when they smashed the looms, a general crisis broke out, springing this time from the crisis of big industry: Fascist regression, sickly dreams of a return to artisanry and corporatism, the Ubuesque master-race of blond beasts.

Today, the promises of the old society of production are raining down on our heads in an avalanche of consumer goods that nobody would venture to call mana from heaven. You can hardly believe in the magical power of gadgets in the same way as people used to believe in 
productive forces. There is a certain hagiographical literature on the steam hammer. One cannot imagine much on the electric toothbrush. The mass production of instruments of comfort - all equally revolutionary according to the publicity handouts - has given the most unsophisticated of men the right to express an opinion on the marvels of technological innovation in a tone as familiar as the hand he sticks up the barmaid's skirt. The first landing on Mars will pass unnoticed on Blackpool beach.

Admittedly, the yoke and harness, the steam engine, electricity and the rise of nuclear energy all disturbed and altered the infrastructure of society (though this was almost accidental). But today it would be foolish to expect new productive forces to upset modes of production. The blossoming of technology has seen the birth of a super-technology of synthesis which could prove as important as the social community, that first of all technical syntheses, founded at the dawn of time. Perhaps more important still; for if cybernetics was taken from its masters, it might be able to free human groups from labour and from social alienation. This was precisely the project of Charles Fourier in an age when utopia was still possible.

But between Fourier and the cyberneticians who control the operational organisation of technology lies the distance between freedom and slavery. Of course, the cybernetic project claims that it is already sufficiently developed to be able to solve all the problems raised by the appearance of a new technique. But don't you believe it

1: The permanent development of productive forces, the exploding mass production of consumer goods, promise nothing. Musical air-conditioners and solar-ovens stand unheralded and unsung. We see a weariness coming, and one that is already so obviously present that sooner or later it's bound to develop into a critique of organisation itself

2: For all its flexibility, the cybernetic synthesis will never be able to conceal the fact that it is only the superseding synthesis of the different forms of government that have ruled over men, and their final stage. How could it hope to disguise the inherent alienation that no power has ever managed to shield from the weapons of criticism and the criticism of weapons?

By laying down the basis for a perfect power structure, the cyberneticians will only stimulate the perfection of refusal. Their programming of new techniques will be shattered by the same techniques turned to its own use by another kind of organisation. A revolutionary organisation

\section{2}

Technocratic organisation raises technical mediation to its highest point of coherence. It has been known for ages that the master uses the slave as a means to appropriate the objective world, that the tool only alienates the worker as long as it belongs to a master. Similarly in the realm of consumption: it's not the goods that are inherently alienating, but the conditioning that leads their buyers to choose them and the ideology in which they are wrapped. The tool in production and the conditioning of choice in consumption are the mainstays of the fraud: they are the mediations which move man the producer and man the consumer to the illusion of action in a real passivity and transform him into an essentially dependent thing. The stolen mediations separate the individual from himself, his desires, his dreams, and his will to live; and so people come to believe in th myth that you can't do without them, or the power that governs them. Where power fails to paralyse with constraints, it paralyses by suggestion: by forcing everyone to use crutches of which it is the sole supplier. Power as the sum of alienating mediations is 
only waiting for the holy water of cybernetics to baptise it into the state of Totality. But total power does not exist, only totalitarian powers. And the baptism of cybernetics has already been cancelled owing to lack of interest.

Because the objective world (or nature, if you prefer) has been grasped by means of alienated mediations (tools, thoughts, false needs), it ends up surrounded by a sort of screen: so that, paradoxically, the more man transforms himself and the world, the more it becomes alien to him. The veil of social relations envelops the natural world totally. What we call 'natural' today is about as natural as Nature Girl lipstick. The instruments of praxis do not belong to the agents of praxis, the workers: and it is obviously because of this that the opaque zone that separates man from himself and from nature has become a part of man and a part of nature. Our task is not to rediscover nature but to make a new one, to reconstruct it.

The search for the real nature, for a natural life that has nothing to do with the lie of social ideology, is one of the most touching naïvetés of a good part of the revolutionary proletariat, not to mention the anarchists and such notable figures as the young Wilhelm Reich.

In the realm of the exploitation of man by man, the real transformation of nature only takes place through the real transformation of the social fraud. At no point in their struggle have man and nature ever been really face to face. They have been kept apart by what mediates this struggle: hierarchical social power and its organisation of appearance. To transform nature was to socialise it, but they certainly made a mess of the job. There is no nature other than social nature, since history has never known a society without power.

Is an earthquake a natural phenomenon? It affects men, but it affects them only as alienated social beings. What is an earthquake-in-itself? Suppose that at this moment there was an earthquake disaster on Alpha Centauri. Who would it bother apart from the old farts in the universities and other centres of pure thought?

And death: death also strikes men socially. In the first place, because the energy and resources poured down the drain of militarism and wasted in the anarchy of capitalism and bureaucracy could make a vital contribution to the scientific struggle against death. But above all because it is in the vast laboratory of society (and under the benevolent eye of science) that the foul brew of culture in which the germs of death are spawned is kept on the boil; (stress, nervous tension, conditioning, pollution, latrogenic disease...) Only animals are still allowed to die a natural death... some of them.

Could it be that, after disengaging themselves from the animal world by means of their history, men might come to envy the animal's contact with nature? This is, I think, the childish meaning which should be seen in the search for the 'natural'. But if we could enrich it and set it off in the right direction such a desire would mean that we had superseded 30,000 years of history.

What we have to do now is to create a new nature that will be a worthwhile adversary: that is, to resocialise it by liberating the technical apparatus from the sphere of alienation, by snatching it from the hands of rulers and specialists. Only at the end of a process of social disalienation will nature become a worthwhile opponent: in a society in which man's creativity will not come up against man himself as the first obstacle to its expansion

Technological organisation can't be destroyed from the outside. It's collapse is the result of internal decay. Far from being punished for its Promethean aspirations, it is dying because it 
never escaped from the dialectic of master and slave. Even if the cybernauts did come to power they'd have a hard time staying there. The very best they can offer has already been turned down in these words from a black worker to a white boss (Presence Africaine, 1956): "When we first saw your trucks and planes we thought that you were gods. Then, after a few years we learned how to drive your trucks, as we shall soon learn how to fly your planes, and we understood that what interested you most was manufacturing trucks and planes and making money. For our part, what we are interested in is using them. Now, you are just our metal-workers." 


\section{Chapter 10. Down Quantity Street}

Economic imperatives seek to impose on the whole of human activity the standardised measuring system of the market. Very large quantities take the place of the qualitative, but even quantity is rationed and economised. Myth is based on quality, ideology on quantity. Ideological saturation is an atomisation into small contradictory quantities which can no more avoid destroying one another than they can avoid being smashed by the qualitative negativity of popular refusal (1). The quantitative and the linear are indissociable. A linear, measured time and a linear, measured life are the definitions of survival, or living on: a succession of inter-changeable instants. These lines are part of the confused geometry of power (2)

1

The system of commercial exchange has come to govern all of man's everyday relations with himself and with his fellow men. Every aspect of public and private life is dominated by the quantitative.

The merchant in The Exception and the Rule confesses: "I don't know what a man is. Only that every man has his price." To the extent that individuals accept power and enable it to exist, power in turn judges them by its own yard-stick: it reduces and standardises them. What is the individual to an authoritarian system? A point duly located in its perspective. A point that it recognises, certainly, but recognises only in terms of the number that define its position in a system of co-ordinates.

The calculation of a man's capacity to produce or to make others produce, to consume or to make others consume, concretises to a $\mathrm{T}$ that expression so dear to our philosophers: the measure of man. Even the simple pleasures of a ride in the country are generally measured up in terms of miles on the clock, speeds reached and petrol consumption. With the rate at which economic 'imperatives' are buying up feelings, desires and needs and falsifying them, man will soon be left with nothing but the memory of having once been alive. Living in the past: the memory of days gone by will be our consolation for living on. How could even spontaneous laughter last in a space-time that is measured and measurable, let alone real joy? At best the dull contentment of the man-who's-got-his-money's-worth, and who exists by that standard. Only objects can be measured, which is why exchange always reifies

Any excitement that could still be found in the pursuit of pleasure is fast disintegrating into a panting succession of mechanical gestures, and one hopes in vain that their rhythm will speed up enought to reach even the semblance of orgasm. The quantitative Eros of speed, novelty, loveagainst-the-clock is disfiguring the real face of pleasure everywhere. 
The qualitative is slowly taking on the aspect of a quantitative infinity, an endless series whose momentary end is always the negation of pleasure, Don Juan's basic “can't get no satisfaction". If only contemporary society would encourage such dissatisfaction, and allow total licence to the delirious and devastating attractions of an insatiable appetite! Who would deny that there is a certain charm in the life of an idler, a trifle blasé perhaps, but enjoying at his leisure everything that can make passivity sweet: a seraglio of pretty girls, witty and sophisticated friends, subtle drugs, seven-course Chinese meals, heady liqueurs and sultry perfumes: a man whose desire is not so much to change life as to seek refuge in the greatest attractions it has to offer. A libertine in the grand style.

Let's talk sense, though. Nowadays that kind of choice just doesn't exist, for in both Western and Eastern societies even quantity is rationed. A tycoon with only on emonth left to livewould still refuse to blow his entire fortune on one huge orgy... the morality of exchange and profit doesn't let go that easily. Thrift, the capitalist economics of family life.

Yet what a windfall for mystification, to have the qualitative imprisoned in the skin of the quantitative! I mean that a world in which all things seem possible can still harbour the illusion of being a world of many dimensions. But to let exchange be subsumed by the gift, to let all kinds of adventures blossom between heaven and earth (from Gilles de Rais to Dante...) this was precisely what the bourgeoisie couldn't do, this was the door that it had closed on itself in the name of industry and commerce! All it had left was a vast nostalgia. Poor and precious catalyst - at once all and nothing - thanks to which a society without class and without authoritarian power will come to realise all the dreams of its aristocratic childhood.

In the act of faith, the unitary societies of tribal and feudal times possessed a qualitative element of myth and mystification which was of major importance. The bourgeoisie, once it had shattered the unity of power and God, found itself clutching fragments and crumbs of power, crumbs which it tried to clothe with a unitary spirit. But it didn't work. Without unity there can be no qualitative! Democracy triumphs along with social atomisation. Democracy is the limited power of the greatest number, and the power of the greatest limited number. The great ideologies very soon abandon faith for numbers. Nowadays 'La Patrie' is no more than a few thousand war veterans. And what Marx and Engels used to call 'our party' is today a few million voters and a couple of thousand bill-stickers: a mass party.

In fact, ideology draws its essence from quantity: it is simply an idea reproduced again and again in time (Pavlovian conditioning) and in space (where the consumers take over). Ideology, information and culture tend more and more to lose their content and become pure quantity. The less importance a piece of news has, the more it is repeated, and the more it distracts people from their real problems. Goebbels said that the bigger the lie, the more easily it is swallowed. But ideology takes us away from the Big Lie by constantly bidding against itself. One after another it lays before us a hundred paperbacks, a hundred washing powders, a hundred political ideas, and with equal conviction proves that each of them is incontestably superior to any of the others. Even in ideology quantity is being destroyed by quantity itself: conflicting conditionings end by cancelling each other out. Is this the way to rediscover the power of the qualitative , a power that can move mountains?

Quite the contrary. Contradictory conditioning is more likely to end in trauma, inhibition and a radical refusal to be brainwashed any more. Admittedly ideology still has one trick up its sleeve - that of posing false questions, raising false dilemmas and leaving the conditioned individual, poor bugger, with the worry of sorting out which is the truer of two lies. But such pointless 
diversions carry little weight compared with the survival sickness to which consumer society exposes its members.

Boredom breeds the irresistible rejection of uniformity, a refusal that can break out at any moment. Stockholm, Amsterdam and Watts (for a start) have shown that the tiniest of pretexts can fire the oil spread on troubled waters. Think of the vast quantity of lies that can be wiped out by one act of revolutionary poetry! From Villa to Lumumba, from Stockholm to Watts, qualitative agitation, the agitation that radicalises the masses because it springs from the radicalism of the masses, is redefining the frontiers of submission and degradation

\section{2}

In unitary regimes the sacred was the cement which held together the social pyramid in which each particular being from the highest lord to the lowest serf had his place according to the will of Providence, the order of the world and the king's pleasure. The cohesion of the structure soon disappeared, dissolved by the corrosive criticism of the young bourgeoisie; but, as we know, the shadow of the divine hierarchy remains. The dismantling of the pyramid, far from destroying the inhuman cement, only pulverises it. We see little particular beings becoming absolute: little 'citizens' released by social atomisation. The inflated imagination of egocentricity creates a universe on the model of one point, a point just the same as thousands of other points, grains of sand, all free, equal and fraternal, scurrying here and there like so many ants when their nest is broken open. All the lines have gone haywire since God disappeared, depriving them of their point of convergence; they weave and collide in apparent disorder. But make no mistake, despite the anarchy of competition and the isolation of individualism, class and caste interests are beginning to tie up, structuring a geometry, and impatient to reconquer its coherence.

Now, the coherence of unitary power, although it's based on the divine principle, is a palpable coherence, which each individual lives in and knows. But paradoxically the material principle of fragmentary power can only furnish an abstract coherence. How could the organisation of economic survival hope to substitute itself smoothly for this immanent, this omnipresent God who is called on to witness the most trivial gestures, like cutting bread and sneezing...? The omnipotence of the feudal mode of domination was quite relative anyway, but let us suppose that with the aid of cyberneticians it could be equalled by a secularised government of men. Even so, how could anyone replace the mythic and poetic ethos surrounding the life of communities thast are socially cohesive, an ethos that provides them with some kind of third dimension? The bourgeoisie is well and truly caught in the trap of its own half-revolution

Quantification implies linearity. the qualitative is plurivalent, the quantitative univocal. Life quantified becomes a measured route-march towards death. The radiant ascent of the soul towards heaven is replaced by inane speculations about the future. Moments of time no longer radiate, as they did in the cyclical time of earlier societies; time is a thread stretching from birth to death, from memories of the past to expectations of the future, on which an eternity of survival strings out a row of instants and hybrid presents nibbled away by what is past an what is yet to come. 
The feeling of living in symbiosis with cosmic forces - the sense of the simultaneous - revealed to our forefathers joy which our passing presence in the world is hard put to provide. What remains of such a joy? Only vertigo, giddy transcience, the effort of keeping up with the times. You must move with the times - the motto of those who make a profit out of it.

Not that we should lament the passing of the old days of cyclical time, the time of mystical effusion. Rather correct it: centre it in man, and not in the divine animal. Man is not the centre of present time, he is merely a point in it. Time is composed of a succession of points, each taken independently of the others like an absolute, but an absolute that is endlessly repeated and rehashed. Because they are located on the same line, all actions and all moments assume equal importance. The definition of prosaism. Down quantity street, everything's always just the same. And these absolutized fragments are all quite interchangeable. Divided from one another - and thus separated from man himself - the moments of survival follow one another and resemble one another just like the specialised attitudes that correspond to them: roles. Making love or riding a motorbike, it's all the same. Each moment has its stereotype, and the fragments of time carry off the fragments of men into a past that can never be changed.

What's the use of threading pearls to make a garland of memories? If only the weight of the pearls would snap the thread! But no: moment by moment, time bores on; everything is lost, nothing created...

What do I want? Not a succession of moments, but one huge instant. A totality that is lived and without the experience of 'time passing'. The feeling of 'time passing' is simply the feeling of growing old. And yet, since one must first of all survive in order to live, virtual moments, possibilities, are necessarily rooted in that time. To federate moments, to bring out the pleasure in them, to release their promise of life is already to be learning how to construct a 'situation'

Individual survival-lines cross, collide and intersect. Each one assigns limits to the freedom of others; projects cancel one another out in the name of their autonomy. This is the basis of the geometry of fragmentary power.

We think we are living in the world, when in fact we are being positioned in a perspective. No longer the simultaneous perspective of primitive painters, but the perspective of the Renaissance rationalists. It is hardly possible for looks, thoughts and gestures to escape the attraction of the distant vanishing-point which orders and deforms them; situates them in its spectacle. Power is the greatest town-planner. It parcels out loys of public and private survival, buys up vacant lots at cut price, and only permits construction that complies with its regulations. Its own plans involve the compulsory acquisition of everybody. It builds with a heaviness which is the envy of the real town-builders that copy its style, translating the old mumbo-jumbo of the sacred hierarchy into stockbroker-belts, white collar apartments and workers flats. (Like, for example, in Croydon)

The reconstruction of life, the rebuilding of the world: one and the same desire. 


\section{Chapter 11. Mediated Abstraction and Abstract Mediation}

Today, reality is imprisoned in metaphysics in the same way as it was once imprisoned in theology. The way of seeing which power imposes, 'abstracts' mediations from their original function, which is to extend into the real world the demands which arise in lived experience; it resists the magnetic pull of authority. The point where resistance begins is the look-out post of subjectivity. Until now, metaphysicians have only organised the world in various ways; the point is to change it, by opposing them (1). The regime of guaranteed survival is slowly undermining the belief that power is necessary (2). This leads to a growing rejection of the forms which govern us, a rejection of their (coercive) ordering principle. (3) Radical theory, which is the only guarantee of the coherence of such a rejection, penetrates the masses because it extends their spontaneous creativity. "Revolutionary" ideology is theory which has been recuperated by the authorities. Words exist as the frontier between the will to live and its repression; the way they are employed determines their meaning; history controls the way in which they are employed. The historical crisis of language indicates the possibility of superseding it towards the poetry of action, towards the great game with signs (4)

$\mathbf{1}$

What is this detour in which I get lost when I try to find myself? What is this screen that separates me from myself under the pretence of protecting me? And how can I ever find myself again in this crumbling fragmentation of which I am composed? I move forward with a terrible doubt of ever getting to grips with myself. It is as though my path is already marked out in front of me, my thoughts and feelings following the contours of a mental landscape which they imagine they are creating, but which in fact is moulding them. An absurd force - all the more absurd for being part of the rationality of the world, and seeming incontestable - keeps me jumping in an effort to reach a solid ground which my feet have never left. And by this useless leap towards myself I succeed only in losing my grip on the present; most of the time I live out of step with what I am, marking time with dead time.

I think that people are surprisingly insensitive to the way in which the world, in certain periods, takes on the forms of the dominant metaphysic. No matter how daft it may seem to us to believe in God and the Devil, this phantom pair become a living reality the moment that a collectivity considers them sufficiently present to inspire the text of their laws. In the same way, the stupid distinction between cause and effect has been able to govern societies in which human behaviour and phenomenae in general were analysed in terms of cause and effect. And in our own time, nobody should underestimate the power of the misbegotten dichotomy between thought and action, theory and practice, real and imaginary... these ideas are forces of organisation. The world of falsehood is a real world, people are killing one another there, and we'd better not forget it. While we spiel and spout ironically about the decay of philosophy, contemporary philosophers 
watch with knowing smiles from behind the mediocrity of their thought; they know that come what may the world is still a philosophical construction, a huge ideological foozle. We survive in a metaphysical landscape. The abstract and alienating mediation which estranges me from myself is terrifyingly concrete.

Grace, a piece of God transplanted into man, outlived its Donor. Secularized, abandoning theology for metaphysics, it remained buried in the individual's flesh like a pace-maker, an internalised mode of government. When Freudian imagery hangs the monster Superego over the doorway of the ego, its fault is not so much facile oversimplification as refusal to search further for the social origin of constraints. (Reich understood this well.) Oppression reigns because men are divided, not only among themselves, but also inside themselves. What separates them from themselves and weakens them is laos the false bond that unites them with power, reinforcing this power and making them choose it as their protector, as their father.

"Mediation", says Hegel, "is self-identity in movement." But what moves can lose itself. And when he adds "it is the moment of dying and becoming", the same words differ radically in meaning according to the perspective in which they are placed: that of totalitarian power or that of the total man.

As soon as mediation escapes my control, every step I take drags me towards something foreign and inhuman. Engels painstakingly showed that a stone, a fragment of nature alien to man, became human as soon as it became an extension of the hand by serving as a tool (and the stone in its turn humanised the hand of the hominid). But once it is appropriated by a master, an employer, a ministry of planning, a management, the tool's meaning is changed: it deflects the action of its user towards other purposes. And what is true of tools is true for all mediations.

Just as God was the supreme arbiter of grace, the magnetism of the governing principle always draws to itself the largest possible number of mediations. Power is the sum of alienated and alienating mediations. Science (scientia theologiae ancilla) converted the divine fraud into operational information, organised abstraction, returning to the etymology of the word: $a b$-trahere, to draw out of.

The energy which the individual expends in order to realise himself and extend into the world according to his desires and dreams, is suddenly braked, held up, shunted onto other tracks, recuperated. What would normally be the phase of fulfilment is forced out of the living world and kicked upstairs into the transcendental.

But the mechanism of abstraction is never completely loyal to the principle of authority. However reduced man may be by his stolen mediation, he can still enter the labyrinth of power with Theseus' weapons of aggression and determination. if he finally loses his way, it is because he has already lost his Ariadne, snapped the sweet thread that links him with life: the desire to be himself. For it is only in an unbroken relationship between theory and lived praxis that there can be any hope of an end to all dualities, the end of the power of man over man, and the beginning of the era of totality.

Human energy does not let itself be led away into the inhuman without a fight. The field of battle is always in the immediate extension of lived experience, in spontaneous action. Not that I am opposing abstract mediation in the name of some sort of wild, 'instinctive' spontaneity; that would merely be to reproduce on a higher level the idiotic choice between pure speculation and mindless activism, the disjunction between theory and practice. I am saying that tactical adequacy involves launching the attack at the very spot where the highwaymen of experience lay their ambush, the spot where the attempt to act is transformed and perverted, at the precise mo- 
ment when spontaneous action is sucked up by misinterpretation and misunderstanding. At this point there is a momentary crystallization of consciousness which illumines both the demands of the will-to-live and the fate that social organisation has in store for them; living experience and its recuperation by the machinery of authoritarianism. The point where resistance begins is the look-out post of subjectivity. For identical reasons, my knowledge of the world has no value except when I act to transform it

\section{2}

The mediation of power works a permanent blackmail on the immediate. of course, the idea that an act can't be carried through in the totality of its implications faithfully reflects the reality of a bankrupt world, a world of non-totality; but at the same time it reinforces the metaphysical character of events, which is their official falsification. Common sense is a compendium of slanders like "We'll always need bosses", "Without authority mankind would sink into barbarism and chaos" and so on. Custom has mutilated man so thoroughly that when he mutilates himself he thinks he is following a law of nature. And perhaps he is chained so firmly to the pillory of submission through suppressing the memory of what he has lost. Anyway, it benefits the slave mentality to associate power with the only possible form of life, survival. And it fits well with the master's purposes to encourage such an idea.

In mankind's struggle for survival, hierarchical social organisation was undeniably a decisive step forward. At one point in history, the cohesion of a collectivity around its leader gave it the best, perhaps the only chance of self-preservation. But the survival was guaranteed at the price of a new alienation: the safeguard was a prison, preserving life but preventing growth. Feudal regimes reveal the contradiction bluntly: serfs, half men and half beasts, existed side-by-side with a small priveleged sector, some of whom strained after individual access to the exuberance and energy of unrestrained living.

The feudal idea cared little about survival as such: famines, plagues and massacres swept millions of beings from that best of all possible worlds without unduly disturbing the generations of literati and subtle hedonists. The bourgeoisie, on the other hand, finds in survival the raw material of its economic interests. The need to eat and subsist materially is bound to be good for trade. Indeed it is not excessive to see in the primacy of the economy, that dogma of bourgeois thought, the very source of its celebrated humanism. If the bourgeoisie prefers man to God, it is because only man produces and consumes, supplies and demands. The divine universe, which is pre-economic, incurs their disapproval almost as much as the post-economic world of the total man.

By force-feeding survival until it is satiated, consumer society awakens a new appetite for life. Wherever survival and work are both guaranteed, the old safeguards become obstacles. Not only does the struggle to survive prevent us from really living; once it becomes a struggle without real goals it begins to threaten survival itself: what was ridiculous becomes precarious. Survival has grown so fat that if it doesn't shed its skin it will choke us all in it and die.

The protection provided by masters has lost its justification since the mechanical solicitude of gadgets theoretically ended the necessity for slaves. From now on, the ultima ratio of the rulers is the deliberately maintained terror of a thermonuclear apocalypse. Peaceful coexistence guarantees their existence. Power no longer protects the people; it protects itself against the 
people. Today, this inhumanity spontaneously created by men has become simply the inhuman prohibition of all creation

\section{3}

Every time the total and immediate completion of an action is deferred, power is confirmed in its function of grand mediator. Spontaneous poetry, on the other hand, is anti-mediation par excellence.

One could say schematically that bourgeois/Soviet fragmentary power, which may be characterized as the sum of constraints, is being absorbed gradually into a form of organisation based more on alienating mediations. Ideological enchantment replaces the bayonet. This perfected mode of government inevitably brings to mind the prophets of cybernetics. Following the prudent directives of the technocratic specialised left, the electronic Argus is planning to eliminate the middlemen (spiritual leaders, putschist generals, Franco-Stalinists and other sons of Ubu) and wire up its Absolute State of well-being. But the more mediations are alienated, the more the thirst for the immediate rages and the savage poetry of revolutions tramples down frontiers.

In its final phase, authority will culminate in the union of abstract and concrete. Power already abstracts, and the electric chair is still neing used. The face of the world, lit up by power, is organised according to a metaphysic of reality: and it's a sight for sore eyes to see the faithful philosophers showing off their new uniforms: technocrat, sociologist, specialist...

The pure form which is haunting society is recognisable as the death of men. It is the neurosis which preceds necrosis, survival sickness spreading slowly as living experience is replaced by images, forms, objects, as alienated mediation transmutes experience into a thing; madreporises it. It's a man or a tree or a stone... as Lautréamont prophesied.

Gombrowicz at least gives due respect to Form, power's old go-between, now promoted to the place of honour among pimps of State:

"You have never really been able to recognize or explain the importance of Form in your life. Even in psychology you have been unable to accord to Form its rightful place. We continue to believe that it is feeling, purposes or ideas that govern our behaviour, considering Form to be at most a harmless ornamental addition. When the widow weeps tenderly beside her husband's coffin, we think that she is crying because she feels her loss so keenly. When some engineer, doctor or lawyer murders his wife, his children or a friend, we suppose that he was driven to the deed by violent or bloodthirsty impulses. When some politician expresses himself vacuously, deceitfully or shabbily in a public speech, we say that he is stupid because he expresses himself stupidly. But the fact of the matter is this: a human being does not externalise himself in an immediate manner, according to his nature, but always through a definite Form; and this Form; and this Form, this way of being, this way of speaking and reacting, does not issue solely from himself but is imposed on him from outside.

"And so the same man can appear sometimes wise, sometimes stupid, blood-thirsty or angelic, according to the Form which affects him and according to the pressure of conditioning... When will you consciously oppose the Forms? When will you stop identifying with what defines you?" 
In this Critique of Hegel's Philosophy of Right, Marx writes:

Theory becomes a material force once it has got hold of the masses. Theory is capable of getting hold of men once it demonstrates its truth with regard to man, once it becomes radical. To be radical is to grasp something at its roots. But for man the root is man himself

In short, radical theory gets hold of the masses because it comes from them in the first place. It is the repository of spontaneous creativity, and its job is to ensure the striking power of this creativity. It is revolutionary technique at the service of poetry. Any analysis of revolutions past or present that does not involve a determination to resume the struggle more coherently and more effectively plays fatally into the hands of the enemy: it is incorporated into the dominant culture. The only time to talk about revolutionary moments is when you are ready to live them at short notice. A simple touchstone for testing the mettle of the clanking thinkers-errant of the planet's left.

Those who are able to end a revolution are always the most eager to explain it to those who have made it. The arguments they use to explain it are as good as their arguments for ending it, one can say that much. When theory escapes from the makers of a revolution it turns against them. It no longer gets hold of them, it dominates and conditions them. The theory developed by the strength of the armed people now develops the strength of those who disarm the people. leninism explains revolutions too - it certainly taught Makhno's partisans and the Kronstadt sailors a thing or two. An ideology.

Whenever the powers-that-be get their hands on theory, it turns into ideology: an argument ad hominem against man in general. Radical theory comes out of the individual, being-as-subject: it penetrates the masses through what is most creative in each person, through subjectivity and the desire for realisation. Ideological conditioning is quite the opposite: the technical management of the inhuman, the weight of things. It turns men into objects which have no meaning apart from the Order in which they have their place. It assembles them in order to isolate them, making the crowd into a multiplicity of solitudes.

Ideology is the falsehood of language and radical theory its truth. The conflict between them, which is the conflict between man and the inhumanity which he secretes, underlies the transformation of the world into human realities as much as its transmutation into metaphysical realities. Everything that men do and undo passes through the mediation of language. Semantics is one of the principal battlefields in the struggle between the will to live and the spirit of submission

The fight is unfair. Words serve power better than they do men; they serve it more faithfully than most men do, and more scrupulously than the other mediations (space, time, technology...) Hypostatised transcendence always depends on language and is developed in a system of signs and symbols, such as words, dance, ritual, music, sculpture and building. When a half-completed action, suddenly obstructed, tries to continue in a form which it hopes will eventually allow it to finish and realise itself - like a generator transforming mechanical energy into electrical energy which will be reconverted into mechanical energy by a motor miles away - at this moment language swoops down on living experience, ties it hand and foot, robs it of its substance, abstracts it. it always has categories ready to condemn to incomprehensibility and nonsense anything which 
they can't contain, or summon into existence-for-power that which slumbers in nothingness because it has no place as yet in the system of Order. The repetition of familiar signs is the basis of ideology.

And yet men still try to use words and signs to perfect their interrupted gestures. This is why a poetic language exists: a language of lived experience which, for me, merges with radical theory, the theory which penetrates the masses and becomes a material force. Even when it is recuperated and turned against its original purpose, poetry always gets what it wants in the end. The "Proletarians of all lands, unite" which produced the Stalinist State will one day realise the classless society. No poetic sign is ever completely tamed by ideology.

The language that diverts radical actions, creative actions, human actions par excellence, from their realisation, becomes anti-poetry. it defines the linguistics of power: its science of information. This information is the model of false communication, the communication of the inauthentic, the non-living. There is a principle that I find holds good: as soon as a language no longer obeys the desire for realisation, it falsifies communication; it no longer communicates anything except that false promise of truth which is called a lie. But this lie is the truth of what destroys me, infects me with its virus of submission. Signs are thus the vanishing points from which diverge the antagonistic perspectives which make up the world and divide it between them: the perspective of power and the perspective of the will to live. Each word, idea or symbol is a double agent. Some, like the word 'fatherland' or the policeman's uniform, usually work for authority; but make no mistake, when ideologies clash or begin to wear out the most mercenary sign can become a good anarchist (I am thinking of the splendid title that Bellegarigue chose for his paper: L'Anarchie, fournal de l'Ordre).

Dominant semiological systems - which are those of the dominant castes - have only mercenary signs, and, as Humpty-Dumpty says, the king pays double time to words he uses a lot. But deep down inside, every mercenary has dreams of killing the king. If we are condemned to a diet of lies we must learn to spike them with a drop of the acid truth. This is the way the agitator works: he charges his words and signs so powerfully with living reality that all the others are pulled out of place. He diverts them.

In a general way, the fight for language is the fight for the freedom to live, for the reversal of perspective. The battle is between metaphysical facts and the reality of facts: I mean between facts conceived statistically as part of a system of interpretation of the world and facts understood in their development by the praxis which transforms them.

Power can't be overthrown like a government. The united front against authority covers the whole extent of everyday life and engages the vast majority of men. To know how to live is to know how to fight against renunciation without ever giving an inch. Let nobody underestimate power's skill in stuffing its slaves with words to the point of making them the slaves of its words.

What weapons do we have to secure our freedom? We can mention three:

1. Information should be corrected in the direction of poetry, news deciphered, official terms translated (so that "society", in the perspective opposed to power, becomes "racket" or "area of hierarchical power") - leading eventually to a glossary or encyclopaedia (Diderot was well aware of their importance and so are the Situationists).

2. Open dialogue, the language of dialectic; conversation, and all forms of non-spectacular discussion 
3. What Jakob Boehme called "sensual speech" (sensualische Sprache) "because it is a clear mirror of the senses". And the author of the Way to God elaborates: "in sensual speech all spirits converse directly, and have no need of any language, because theirs is the language of nature." if you remember what I have called the recreation of nature, the language Boehme talks about clearly becomes the language of spontaneity, of "doind", of individual and collective poetry; language centred on realisation, leading lived experience out of the cave of history. This is also connected with what Paul Brousse and Ravachol understood by "propoganda of the deed"

There is a silent communication; it is well known to lovers. At this stage language seems to lose its importance as essential mediation, thought is no longer a distraction (in the sense of leading us away from ourselves), words and signs become a luxury, an exuberance. think of those bantering conversations with their baroque of cries and caresses which are so surprisingly ridiculous for those who do not share the lovers' intoxication. but it was also direct communication that Léhautier referred to when the judge asked him what anarchists he knew in Paris: :Anarchists don't need to know one another to think the same thing." In radical groups which are able to reach the highest level of theoretical and practical coherence, words will sometimes acquire this privelege of playing and making love: erotic communication.

An aside: history has often been accused of happening back-to-front; the question of language becoming superfluous and turning into language-game is another example. A baroque current runs through the history of thought, making fun of words and signs with the subversive intention of disturbing the semiological order and Order in general. But the series of attempts on the life of language by the rabble of tumbloing nonsense-rhymers whose prize fools were Lear and Carroll finds its true expression in the Dada explosion. In 1916, the desire to have it out with signs, thoughts and words corresponded for the first time to a real crisis of communication. The liquidation of language that had so often been undertaken speculatively had a chance to find its historical realisation at last.

In an epoch which still had all its transcendental faith inlanguage, and in God, the master of all transcendence, doubts about signs could only lead to terrorist activity. When the crisis of human relationships shattered the unitary web of mythical communication, the attack on language took on a revolutionary air. So much so that it is tempting to say, as Hegel might have, that the decomposition of language chose Dada as the medium through which to reveal itself to the minds of men. Under the unitary regime the same desire to play with signs had been betrayed by history and found no response. By exposing falsified communication Dada began to supersede language in the direction of poetry. Today the language of myth and the language of spectacle are giving way to the reality which underlies them: the language of deeds. This language contains in itself the critique of all modes of expression and is thus a continuous auto-critique. Poor little sub-dadaists! Because they haven't understood that Dada necessarily implies this supersession, they continue to mumble that we talk like deaf men. Which is one way to be a fat maggot in the spectacle of cultural decomposition

The language of the whole man will be a whole language: perhaps the end of the old language of words. Inventing this language means reconstructing man right down to his unconscious. 
Totality is hacking its way through the fractured non-totality of thoughts, words and actions towards itself. We will have to speak until we can do without words. 


\section{Impossible Realisation or Power As the Sum of Seductions}


Where constraint breaks people, and mediation makes fools of them, the seduction of power is what makes them love their oppression. Because of it people give up their real riches: (a) for a cause that mutilates them [chapter twelve], (b) for an imaginary unity that fragments them [chapter thirteen], (c) for an appearance that reifies them [chapter fourteen], (d) for roles that wrest them from authentic life [chapter fifteen], (e) for a time whose passage defines and confines them [chapter sixteen]. 


\section{Chapter 12. Sacrifice}

There is such a thing as a reformism of sacrifice that is really a sacrifice to reformism. Humanistic self-mortification and fascistic self-destruction both leave us nothing - not even the option of death. All causes are equally inhuman. But the will to live raises its voice against this epidemic of masochism, wherever there is the slightest pretext for revolt; for what appear to be merely partial demands actually conceal the process whereby a revolution is being prepared: the nameless revolution, the revolution of everyday life (1). The refusal of sacrifice is the refusal to be bartered: human beings are not exchangeable. Henceforward the appeal to voluntary self-sacrifice is going to have to rely on three strategies only: on art, on "great human values," and on the present (2).

1

Where people are not broken - and broken in - by force and fraud, they are seduced. What are Power's methods of seduction? Internalized constraints which ensure a good conscience based on a lie: the masochism of the honnête homme. Thus Power castrates but calls castration selfdenial; it offers a choice of servitudes but calls this choice liberty. The feeling of having done one's duty is Power's reward for self-immolation with honor.

As I showed in "Banalités de base" (Internationale Situationiste, issues 7-8; English version: "The Totality for Kids"), the master-slave dialectic implies that the mythic sacrifice of the master embodies within itself the real sacrifice of the slave: the master makes a spiritual sacrifice of his real power to the general interest, while the slave makes a material sacrifice of his real life to a power which he shares in appearance only. The framework of generalized appearances or, if you will, the essential lie required for the development of privative appropriation (i.e., the appropriation of things by means of the appropriation of beings) is an intrinsic aspect of the dialectic of sacrifice, and the root of the infamous separation that this involves. The mistake of the philosophers was that they built an ontology and the notion of an unchanging human nature on the basis of a mere social accident, a purely contingent necessity. History has been seeking to eliminate privative appropriation ever since the conditions which called for it ceased to exist. But the metaphysical maintenance of the philosophers' error continues to work to the advantage of the masters, of the 'eternal' ruling minority.

The decline and fall of sacrifice parallels the decline and fall of myth. Bourgeois thought exposes the materiality of myth, deconsecrating and fragmenting it. lt does not abolish it, however, because if it did the bourgeoisie would cease to exploit - and hence to exist. The fragmentary spectacle is simply one phase in the decomposition of myth, a process today being accelerated by the dictates of consumption. Similarly, the old sacrifice-gift ordained by cosmic forces has shrivelled into a sacrifice-exchange minutely metered in terms of social security and social-democratic 
justice. And sacrifice attracts fewer and fewer devotees, just as fewer and fewer people are seduced by the miserable show put on by ideologies. The fact is that today's tiny masturbations are a feeble replacement indeed for the orgastic heights offered by eternal salvation. Hoping for promotion is a far cry from hoping - albeit insanely - for life everlasting. Our only gods are heroes of the fatherland, heroes of the shop floor, heroes of the frigidaire, heroes of fragmented thought...How are the mighty fallen!

Nevertheless. The knowledge that an ill's end is in sight is cold comfort when you still have to suffer it in the immediate. And the praises of sacrifice are still sung on every side. The air is filled with the sermonizing of red priests and ecumenical bureaucrats. Vodka mixed with holy water. Instead of a knife between our teeth we have the drool of Jesus Christ on our lips. Sacrifice yourselves joyfully, brothers and sisters! For the Cause, for the Established Order, for the Party, for Unity, for Meat and Potatoes!

The old socialists used to like saying, "They say we are dying for our country, but really we are dying for Capital." Nowadays their bureaucratic heirs are berated in similar terms: "You think you're fighting for the proletariat, but really you die for your leaders." "We are not building for the future; men and steel are the same thing in the eyes of the five-year-plan." And yet, what do young leftist radicals do after stating these obvious truths? They enter the service of a Cause - the 'best' of all Causes. The time they have for creative activity they squander handing out leaflets, putting up posters, demonstrating or heckling local politicians. They become militants, fetishizing action because others are doing their thinking for them. Sacrifice seems to have an endless series of tricks up its sleeve.

The best cause is one in which the individual can lose himself body and soul. The principle of death is simply the denial of the principle of the will to live. One or other of these principles must win out, however. There is no middle ground, no possibility of compromise between them on the level of consciousness. And you have to fight for one or for the other. Fanatics of established orders - Chouans, Nazis, Carlists - display their unequivocal choice of the party of death with absolute consistency. The fascist slogan Viva la Muerte! must at least be given credit for pulling no punches. By contrast, our reformists of death in small doses and socialists of ennui cannot even claim the dubious honor of having an aesthetic of total destruction. All they can do is mitigate the passion for life, stunting it to the point where it turns against itself and changes into a passion for destruction and self-destruction. They oppose concentration camps, but only in the name of moderation - in the name of moderate power and moderate death.

Great despisers of life that they are, the partisans of absolute self-sacrifice to State, Cause or Fuhrer do have one thing in common with those whose passion for life challenges the ethos and techniques of renunciation. Though antagonistic, their respective perceptions of revelry are equally sharp. Life being so Dionysian in its essence, it is as though the partisans of death, their lives twisted by their monstrous asceticism, manage to distill all the joy that has been lost to them into the precise moment of their death. Spartan legions, mercenaries, fanatics, suicide squads all experience an instant of bliss as they die.

But this is a fuite macabre, frozen, aestheticized, caught for eternity in a camera flash. The paratroopers that Bigeard speaks of leave this world through the portal of aesthetics: they are petrified figures, madrepores - conscious, perhaps, of their ultimate hysteria. For aesthetics is carnival paralyzed, as cut off from life as a Jibaro head, the carnival of death. The aesthetic element, the element of pose, corresponds to the element of death secreted by everyday life. Every 
apocalypse is beautiful, but this beauty is a dead one. Remember the song of the Swiss Guard that $\mathrm{C}$ ? taught us to love.

The end of the Commune was no apocalypse. The difference between the Nazis dreaming of bringing the world down with them and the Communards setting Paris on fire is the difference between total death brutally affirmed and total life brutally denied. The Nazis merely operated the mechanism of logical annihilation already designed by humanists preaching submission and abnegation. The Communards knew that a life constructed with passion cannot be taken away; that there is more pleasure in destroying such a life than in seeing it mutilated; and that it is better to go up in flames with a glad heart than to give an inch, when giving an inch is the same as giving up all along the line. "Better die on our feet than live on our knees!" Despite its repulsive source - the lips of the Stalinist Ibarruri - it seems to me that this cry eloquently expresses the legitimacy of a particular form of suicide, a good way of taking leave. And what was valid for the Communards holds good for individuals today.

Let us have no more suicides from weariness, which come like a final sacrifice crowning all those that have gone before. Better one last laugh, à la Cravan, or one last song, à la Ravachol.

The moment revolution calls for self-sacrifice it ceases to exist. The individual cannot give himself up for a revolution, only for a fetish. Revolutionary moments are carnivals in which the individual life celebrates its unification with a regenerated society. The call for sacrifice in such a context is a funeral knell. Jules Vallée fell short of his own train of thought when he wrote: "If the submissive do not outlive the rebellious, one might as well rebel in the name of an idea." For a militant can only be a revolutionary in spite of the ideas which he agrees to serve. The real Vallée, the Communard Vallée, is first the child, then the student, making up in one long Sunday for all the endless weeks that have gone before. Ideology is the rebel's tombstone, its purpose being to prevent his coming back to life.

When the rebel begins to believe that he is fighting for a higher good, the authoritarian principle gets a fillip. Humanity has never been short of justifications for giving up what is human. ln fact some people possess a veritable reflex of submission, an irrational terror of freedom; this masochism is everywhere visible in everyday life. With what agonizing facility we can give up a wish, a passion, stemming from the most essential part of ourselves. With what passivity, what inertia, we can accept living or acting for some thing - 'thing' being the operative word, a word whose dead weight always seems to carry the day. It is hard to be oneself, so we give up as quickly as possible, seizing whatever pretext offers itself: love of children, of reading, of artichokes, etc, etc. Such is the abstract generality of the ill that our desire for a cure tends to evaporate.

And yet, the reflex of freedom also knows how to exploit a pretext. Thus a strike for higher wages or a rowdy demonstration can awaken the carnival spirit. As I write thousands of workers around the world are downing tools or picking up guns, ostensibly in obedience to directives or principles, but actually, at the profoundest level, in response to their passionate desire to change their lives. The real demand of all insurrectionary movements is the transformation of the world and the reinvention of life. This is not a demand formulated by theorists: rather, it is the basis of poetic creation. Revolution is made everyday despite, and in opposition to, the specialists of revolution. This revolution is nameless, like everything springing from lived experience. Its explosive coherence is being forged constantly in the everyday clandestinity of acts and dreams. 
No other problem is as important to me as a difficulty I encounter throughout the long daylight hours: how can I invent a passion, fulfill a wish or construct a dream in the daytime in the way my mind does spontaneously as I sleep? What haunts me are my unfinished actions, not the future of the human race or the state of the world in the year 2000. I could not care less about hypothetical possibilities, and the meandering abstractions of the futurologists leave me cold. If I write, it is not, as they say, "for others." I have no wish to exorcise other people's ghosts. I string words together as a way of getting out of the well of isolation, because I need others to pull me out. I write out of impatience, and with impatience. I want to live without dead time. What other people say interests me only in as much as it concerns me directly. They must use me to save themselves just as I use them to save myself. We have a common project. But it is out of the question that the project of the whole man should entail a reduction in individuality. There are no degrees in castration. The apolitical violence of the young, and its contempt for the interchangeable goods displayed in the supermarkets of culture, art and ideology, are a concrete confirmation of the fact that the individual's self-realization depends on the application of the principle of "every man for himself," though this has to be understood in collective terms - and above all in radical terms.

At that stage in a piece of writing where people used to look for explanations, I would like them from now on to find a settling of scores.

\section{2}

The refusal of sacrifice is the refusal to be bartered. There is nothing in the world of things, exchangeable for money or not, which can be treated as equivalent to a human being. The individual is irreducible. He is subject to change but not to exchange. Now, the most superficial examination of movements for social reform shows that they have never demanded anything more than a cleaning-up of exchange and sacrifice, making it a point of honor to humanize inhumanity and make it attractive. And every time slaves try to make their slavery more bearable they are striking a blow for their masters.

The "road to socialism" consists in this: as people become more and more tightly shackled by the sordid relations of reification, the tendency of the humanitarians to mutilate people in an egalitarian fashion grows ever more insistent. And with the deepening crisis of the virtues of self-abnegation and of devotion generating a tendency towards radical refusal, the sociologists, those watchdogs of modern society, have been called in to peddle a subtler form of sacrifice: art.

The great religions succeeded in turning people's wretched earthly existence into a time of voluptuous expectation: at the end of this valley of tears lay life eternal in God. According to the bourgeois conception, art is better equipped than God to bestow eternal glory on people. The art-in-life-and-in-God of unitary social systems (Egyptian statuary, African art, etc.) gave way to an art which complemented life and sought to make up for the absence of God (fourth-century Greece, Horace, Ronsard, Malherbe, the Romantics, etc.). The builders of cathedrals cared as little for posterity as did de Sade. Their salvation was guaranteed by God, as de Sade's was guaranteed by himself: neither sought a place in the museum of history. They worked for a supreme state of being, not for the temporal survival of their work or for the admiration of centuries to come. 
History is the earthly paradise of the bourgeois idea of transcendence. This realm is accessible not through commodities but through apparent gratuity: through the sacrifice called for by the work of art, through activity seemingly undetermined by the immediate need to increase capital. The philanthropist does good works; the patriot produces heroism; the soldier fashions victory; the poet or scholar creates works of literary or scientific value, and so on. But there is an ambiguity in the very idea of "making a work of art," for it embraces both the lived experience of the artist and the sacrifice of this experience to the abstraction of a creative substance, i.e., to the aesthetic form. The artist relinquishes the lived intensity of the creative moment in exchange for the durability of what he creates, so that his name may live on in the funereal glory of the museum. And his desire to produce a durable work is the very thing that prevents him from living imperishable instants of real life.

Actually, if we except academicism, artists never succumb completely to aesthetic assimilation. Though he may abdicate his immediate experience for the sake of appearances, any artist - and anyone who tries to live is an artist - must also follow his desire to increase his share of dreams in the objective world of others. In this sense he entrusts the thing he creates with the mission of completing his personal self-realization within the collectivity. And in this sense creativity is revolutionary in its essence.

The spectacle, in ideology, art and culture, turns the wolves of spontaneity into the sheepdogs of knowledge and beauty. Literary anthologies are replete with insurrectionary writings, the museums with calls to arms. But history does such a good job of pickling them in perpetuity that we can neither see nor hear them. ln this area, however, consumer society performs a salutary task of dissolution. For today art can only construct plastic cathedrals. The dictatorship of consumption ensures that every aesthetic collapses before it can produce any masterpieces. Premature burial is an axiom of consumerism, imperfection a precondition of planned obsolescence. Sensational aesthetic departures occur only because someone briefly finds a way to outdo the spectacle of artistic decomposition in its own terms. And any such originality soon turns up mass-marketed in every five-and-dime. Bernard Buffet, pop art, Andy Warhol, rock music - where are you now? To talk of a modern work of art enduring is sillier than talking of the eternal values of Standard Oil.

As for the progressive sociologists, once they had finished shaking their heads sadly over the discovery that the value of the art object had become nothing but its market price, and that the artists were working according to the norms of profitability, they decided that we should return to the source of art, to everyday life - not in order to change it, of course, for such is not their function, but rather to make it the raw material for a new aesthetic which would defy packaging techniques and so remain independent of buying and selling. As though there were no such thing as consuming on the spot! The result? Sociodramas and happenings which supposedly provoke spontaneous participation on the part of the spectators. The only thing the spectators participate in, though, is an aesthetic of nothingness. The only thing that can be expressed in the mode of the spectacle is the emptiness of everyday life. And indeed, what better commodity than an aesthetic of emptiness? The accelerating decomposition of values has itself become the only available form of entertainment. The trick is that the spectators of the cultural and ideological vacuum are here enlisted as its organizers. The spectacle's inanity is made up for by forcing its spectators - passive agents par excellence - to participate in it. The ultimate logic of the happening and its derivatives is to supply the society of masterless slaves, which the cyberneticians have planned for us, with the spectatorless spectacle it will require. For artists in the strict sense of the word, the road to 
complete assimilation is well posted: they have merely to follow the progressive sociologists and their ilk into the super-corporation of specialists. They may rest assured that Power will reward them well for applying their talents to the job of dressing up the old conditioning to passivity in bright new colors.

From the perspective of Power, everyday life is a latticework of renunciations and mediocrity. A true void. An aesthetic of daily life would make us all into artists responsible for organizing this nothingness. The final ploy of official art will be the attempt to lend therapeutic features to what Freud, in a dubious simplification, referred to as the death instinct - i.e., rapturous submission to authority.

Wherever the will to live fails to spring spontaneously from individual poetry, there falls the shadow of the crucified Toad of Nazareth. The artist in every human being can never be brought out by regression to artistic forms defined by the spirit of sacrifice. We have to go back to square one.

The surrealists - or some of them at any rate - understood that the only valid transcendence of art lay in direct experience, in works that no ideology could assimilate into its internally consistent lie. They came to grief, of course, precisely because of their complaisant attitude towards the cultural spectacle. Admittedly, the current process of decomposition of thought and art has made the danger of aesthetic assimilation much less than it was in the thirties. The present state of affairs tends to favor situationist agitation.

Much mournful wailing has gone on - since surrealism's demise, in fact - over the disappearance of idyllic relationships such as friendship, love and hospitality. But make no mistake: all this nostalgia for the more human virtues of the past answers to one thing and one thing only, namely, the impending need to revive the idea of sacrifice, which has been coming under too heavy fire. The fact is that there will never be any friendship, or love, or hospitality, or solidarity, so long as self-abnegation exists. The call for self-denial always amounts to an attempt to make inhumanity attractive. Here is an anecdote of Brecht's that makes the point perfectly. To illustrate the proper way of doing a service for friends, and to entertain his listeners, Herr K tells a story. Three young people once came to an old Arab and said: "Our father is dead. He left us seventeen camels, but he laid down in his will that the eldest son should have a half, the second son a third, and the youngest a ninth part of his possessions. Try as we will, we cannot agree on how to divide up the camels. So we'd like to leave it up to you to decide." The old man thought it over before replying: "l see that you need another camel before you can share them out properly. Take mine. lt's the only one I have but it's at your disposal. Take it, divide the beasts up, and bring me back whatever you have left over." The young men thanked him for his friendly offer, took his camel and divided up the eighteen animals as follows: the eldest took a half, which was nine camels, the second son took a third, which was six, and the youngest took his ninth, which was two. To everyone's surprise there was still one camel remaining, and this they promptly returned with renewed thanks to their old friend. According to Herr K, this was the perfect example of the correct way to do a friend a service because nobody had to make a sacrifice. Here is a model which should be made axiomatic and strictly applied to all of everyday life.

lt is not a question of opting for the art of sacrifice as opposed to the sacrifice of art, but rather of putting an end to sacrifice as art. The triumph of an authentic savoir-vivre and of the 
construction of authentically lived situations exists everywhere as a potentiality, but everywhere these tendencies are distorted by the falsification of what is human.

Perhaps the sacrifice of the present turn out to be the last stage of a rite that has maimed humanity since its beginnings. Our every moment crumbles into bits and pieces of past and future. We never really give ourselves over completely to what we are doing, except perhaps in orgasm. Our present is grounded in what we are going to do later and in what we have just done, with the result that it always bears the stamp of unpleasure. In collective as well as in individual history, the cult of the past and the cult of the future are equally reactionary. Everything which has to be built has to be built in the present. According to a popular belief, the drowning man relives his whole life in the instant of his death. For my part I am convinced that we have intense flashes of lucidity which distil and remake our entire lives. Future and past are docile pawns of history which merely cover up the sacrifice of the present. I want to exchange nothing - not for a thing, not for the past ${ }^{*}$ not for the future. I want to live intensely, for myself grasping every pleasure firm in the knowledge that what is radically good for me will be good for everyone. And above all I would promote this one watchword: "Act as though there were no tomorrow." 


\section{Chapter 13. Separation}

Privative appropriation, the basis of social organization, keeps individuals separated from themselves and from others. Artificial unitary paradises seek to conceal this separation by assimilating, more or less successfully, people's prematurely shattered dreams of unity. To no avail. People may be forced to swing back and forth across the narrow gap between the pleasure of creating and the pleasure of destroying, but this very oscillation suffices to bring Power to its knees.

People live separated from one another, separated from what they are in others, and separated from themselves. The history of humanity is the history of one basic separation which precipitates and determines all the others: the social distinction between masters and slaves. By means of history men try to find one another and attain unity. The class struggle is but one stage, though a decisive one, in the struggle for the whole man.

Just as the ruling class has every reason in the world to deny the existence of the class struggle, so the history of separation is necessarily indistinguishable from the history of the dissimulation of separation. This mystification results less from a deliberate intent than from a long drawn out and confused battle in which the desire for unity has generally ended up being transformed into its opposite. Wherever separation is not totally eliminated it is reinforced. When the bourgeoisie came to power, fresh light was shed on the factors which divide men in this most essential way, for bourgeois revolution laid bare the social and material character of separation.

What is God? The guarantor and quintessence of the myth used to justify the domination of man by man. This repellent invention has no other raison d'être. As myth decomposes and passes into the stage of the spectacle, the Grand External Object, as Lautréamont called him, is shattered by the forces of social atomization and degenerates into a remedy for intimate use only - a sort of salve for social diseases.

At the high point of the crisis brought on by the end of classical philosophy and of the ancient world, Christianity's genius lay in the fact that it subordinated the recasting of a mythic system to one fundamental principle: the doctrine of the Trinity. What does this dogma of the Three in One, which caused so much ink and blood to flow, really mean?

Man belongs to God in his soul, to the temporal authority in his body, and to himself in his spirit. His salvation depends on his soul, his liberty on his spirit, his earthly existence on his body. The soul envelops the body and the spirit, and without the soul these are as nothing. If we look more closely at this schema, we find an analogy for the union of master and slave under the principle of man envisaged as a divine creature. The slave is the body, the labor power appropriated by the lord; the master is his spirit which governs the body and invests it with a small part of its higher essence. The slave sacrifices himself in body to the power of the master, while the master sacrifices himself in spirit to the community of his slaves (e.g., the king 'serving' his people, de Gaulle 'serving' France, the Pope washing the feet of the poor). The slave abdicates his earthly 
life in exchange for the feeling of being free, that is, for the spirit of the master come down into him. Consciousness mystified is mythic consciousness. The master makes a notional gift of his master's power to all those whom he governs. By drenching the alienation of bodies in the subtler alienation of the spirit, he economizes on the amount of violence needed to maintain slavery. The slave identifies in spirit, or at least he may, with the master to whom he gives up his life force. But whom can the master identify with? Not with his slaves qua possessions, qua bodies, certainly: rather, with his slaves qua emanation of the spirit of mastery itself, of the master supreme. Since the individual master must sacrifice himself on the spiritual plane, he has to find someone or something within the coherent mythic system to make this sacrifice to: this need is met by a notion of mastery-in-itself of which he partakes and to which he submits. The historically contingent class of masters had thus to create a God to bow down to spiritually and with whom to identify. God validated both the master's mythic sacrifice to the public good and the slave's real sacrifice to the master's private and privative power. God is the principle of all submission, the night which makes all crimes lawful. The only illegal crime is the refusal to accept a master. God is a harmony of lies, an ideal form uniting the slave's voluntary sacrifice (Christ), the consenting sacrifice of the master (the Father; the slave as the master's son), and the indissoluble link between them (the Holy Ghost). The same model underlies the ideal picture of man as a divine, whole and mythic creature: a body subordinated to a guiding spirit working for the greater glory of the soul - the soul being the all embracing synthesis.

We thus have a type of relationship in which two terms take their meaning from an absolute principle, from an obscure and inaccessible norm of unchallengeable transcendence (God, blood, holiness, grace, etc.). Innumerable dualities of this type were kept bubbling for century after century like a good stew on the fire of mythic unity. Then the bourgeoisie took the pot off the fire and was left with nothing but a vague nostalgia for the warmth of the unitary myth and a set of cold and flavorless abstractions: body and spirit, being and consciousness, individual and society, private and public, general and particular, etc., etc. Ironically, though moved by class interests, the bourgeoisie destroyed the unitary myth and its tripartite structure to its own detriment. The wish for unity, so effectively fobbed off by the mythic thinking of unitary regimes, did not disappear along with those regimes: on the contrary, the wish became all the more urgent as the material nature of separation became clearer and clearer to people's consciousness. By laying bare the economic and social foundations of separation, the bourgeoisie supplied the arms which will serve to end separation once and for all. And the end of separation means the end of the bourgeoisie and of all hierarchical power. This is why no ruling class or caste can effect the transformation of feudal unity into real unity, into true social participation. This mission can only be accomplished by the new proletariat, which must forcibly wrest the third force (spontaneous creation, poetry) from the gods, and keep it alive in the everyday life of all. The transient period of fragmentary power will then be seen in its true light as a mere moment of insomnia, as the vanishing point prerequisite to the reversal of perspective, as the step back preparatory to the leap of transcendence.

History testifies to the struggle waged against the unitary principle and to the ways in which a dualistic reality began to emerge. The challenge was voiced to begin with in a theological language, the official language of myth. Later the idiom became that of ideology, the idiom of 
the spectacle. In their preoccupations, the Manichaeans, the Cathari, the Hussites, the Calvinists, etc, have much in common with such figures as Jean de Meung, La Boème or Vanino Vanini. We find Descartes desperately locating the soul, for want of any better place, in the pineal gland. The Cartesian God is a funambulist balancing for some perfectly unaccountable reason atop a perfectly intelligible world. Pascal's, by contrast, hides himself from view, so depriving man and the world of a justification without which they are left in meaningless confrontation, each being the only criterion for judging the other: how can something be measured against nothing?

By the close of the eighteenth century the fabric was rending in all directions as the process of decomposition began to speed up. This was the beginning of the era of "little men" in competition. Fragments of human beings claimed the status of absolutes: matter, mind, consciousness, action, universal, particular - what God could put this Humpty Dumpty together again?

The spirit of feudal lordship had found an adequate justification in a certain transcendence. But a capitalist God is an absurdity. Whereas lordship called for a trinitarian system, capitalist exploitation is dualistic. Moreover, it cannot be dissociated from the material nature of economic relationships. The economic realm is no mystery: the nearest things to miracles here are the element of chance in the functioning of the market and the perfect programming of computerized planning. Calvin's rational God is much less attractive than the loans with interest that Calvinism authorizes so readily. As for the God of the Anabaptists of Munster and of the revolutionary peasant of 1525 , he is a primitive expression of the irrepressible thrust of the masses towards a society of whole men.

The mystical authority of the feudal lord was very different from that instituted by the bourgeoisie. For the lord did not simply change his role and become a factory boss: once the mysterious superiority of blood and lineage is abolished, nothing is left but a mechanics of exploitation and a race for profit which have no justification but themselves. Boss and worker are separated not by any qualitative distinction of birth but merely by quantitative distinctions of money and power. Indeed, what makes capitalist exploitation so repulsive is the fact that it occurs between 'equals'. All the same, the bourgeoisie's work of destruction - though quite unintentional-ly, of course - reveals the justification for even revolution. When peoples stop being fooled they stop doing what they are told.

Fragmentary power carries fragmentation to the point where the human beings over which it holds sway themselves become contradictory. At the same time the unitary lie breaks down. The death of God democratizes the consciousness of separation. What was the "Romantic agony" if not a response to the pain of this split? Today we see it in every aspect of life: in love, in the human gaze, in nature, in our dreams, in reality. Hegel spoke of the tragedy of consciousness; he would have been nearer the mark had he spoken of a consciousness of tragedy. We find such a consciousness in revolutionary form in Marx. A far more comforting picture, from the viewpoint of Power, is offered by Peter Schlemiel setting off in search of his own shadow so as to forget that he is really a shadow in search of a body. The bourgeoisie's invention of artificial unitary paradises is a self-defensive reflex which is more or less successful in retrieving the old enchantment and reviving prematurely shattered dreams of unity.

Thus in addition to the great collective onanisms - ideologies, illusions of social unity, herd mentalities, opiums of the people - we are offered a whole range of marginal solutions lying in 
the no-man's-land between the permissible and the forbidden: individualized ideology, obsession, monomania, unique (and hence alienating) passions, drugs and other highs (alcohol, the cult of speed and rapid change, of rarefied sensations, etc). Now all these pursuits allow us to lose ourselves completely while preserving the impression of self-realization, but the corrosiveness of such activities stems above all from their partial quality. The passion for play is no longer alienating wherever the person who gives himself up to it seeks play in the whole of life - in love, in thought, in the construction of situations. In the same way the wish to kill is no longer megalomania if it is combined with revolutionary consciousness.

Unitary palliatives thus entail two risks for Power. In the first place they fail to satisfy, and in the second they tend to foster the will to build a real social unity. Mystical elevation led only to God; by contrast, horizontal historical progression towards a dubious spectacular unity is infinitely finite. It creates an unlimited appetite for the absolute, yet its quantitative nature is limiting by definition. Its mad rush, therefore, must sooner or later debouch into the qualitative, whether in a negative way or - should a revolutionary consciousness prevail - through the transformation of negativity into positivity. The negative road does not lead to self-realization: it precipitates us into a willful self-destruction. Madness deliberately sought, the voluptuousness of crime and cruelty, the convulsive lightning of perversity - these are the enticing paths open to such unrepentant self-annihilation. To take them is merely to respond with unusual enthusiasm to the gravitational pull of Power's own tendency to dismember and destroy. But if it is to last, Power has to shackle its destructiveness: the good general oppresses his men, he does not execute them. On the other hand, it remains to be seen whether nothingness can be successfully doled out drop by drop. The limited pleasures derived from self-destruction could end up bringing down the power which sets such limits to pleasure. We only have to look at Stockholm or Watts to see that negative pleasure is forever on the point of tipping over into total pleasure - a little shove, and negative violence releases its positivity. I believe that all pleasure embodies the search for total, unitary satisfaction, in every sphere - a fact which I doubt Huysmans had the humor to see when he solemnly described a man with an erection as 'insurgent'.

The complete unchaining of pleasure is the surest way to the revolution of everyday life, to the construction of the whole man. 


\section{Chapter 14. The Organization of Appearances}

The organization of appearances is a system for protecting the facts. A racket. lt represents the facts in a mediated reality to prevent them emerging in unmediated form. Unitary power organized appearances as myth. Fragmentary power organizes appearances as spectacle. Challenged, the coherence of myth became the myth of coherence. Magnified by history, the incoherence of the spectacle turns into the spectacle of incoherence (eg, pop art, a contemporary form of consumable putrefaction, is also an expression of the contemporary putrefaction of consumption) (1). The poverty of 'the drama' as a literary genre goes hand in hand with the colonization of social space by theatrical attitudes. Enfeebled on the stage, theatre battens on to everyday life and attempts to dramatize everyday behaviour. Lived experience is poured into the moulds of roles. The job of perfecting roles has been turned over to experts (2).

\section{1}

The ideal world," says Nietzsche, "is a lie invented to deprive reality of its value, its meaning, its truth. Until now the ideal has been the curse of reality. This lie has so pervaded humanity that it has been perverted and has falsified itself even in its deepest instincts, even to the point where it bows down to values directly opposed to those which formerly ensured progress by ensuring the self-transformation of the present." The lie of the ideal is of course merely the truth of the masters. When theft needs legal justification, when authority raises the banner of the general interest while pursuing private ends with impunity, is it any wonder that the lie fascinates the minds of men, twisting them to fit its laws until their contortions come to resemble 'natural' human postures? And it is true that man lies because in a world governed by lies he cannot do otherwise: he is falsehood himself, he is trapped in his own falsehood. Common sense never underwrites anything except the decree promulgated in the name of everyone against the truth. Common sense is the lie put into lay terms.

All the same, nobody lies groaning under the yoke of inauthenticity twenty-four hours a day. There are always a few radical thinkers in whom a truthful light shines briefly through the lie of words; and by the same token there are very few alienations which are not shattered every day for an instant, for an hour, for the space of a dream, by subjective refusal. Words are never completely in the thrall of Power, and no one is ever completely unaware of what is destroying him. When these moments of truth are extended they will turn out to have been the tip of the iceberg of subjectivity destined to sink the Titanic of the lie.

After shattering myth, the tide of materialism has washed its fragments out to sea. Once the motor force of this tide, the bourgeoisie will end up as so much foam drifting out along with all the flotsam. When he describes the mechanism whereby the king's hired assassin returns in due time 
to carry out his orders upon the one who gave them, Shakespeare seems to offer us a curiously prophetic account of the fate reserved for the class that killed God. Once the assassins of the established order lose their faith in the myth, or, in other words, in the God who legalizes their crimes, the machinery of death is turned against its devisers. Revolution was the bourgeoisie's finest invention. It is also the running noose which will help it take its leap into oblivion. It is easy to see why bourgeois thought, strung up as it is on a rope of radicalism of its own manufacture, clings with the energy of desperation to every reformist solution, to anything that can prolong its life, even though its own weight must inevitably drag it down to its doom. Fascism is in a way a consistent response to this hopeless predicament. It is like an aesthete dreaming of dragging the whole world down with him into the abyss, lucid as to the death of his class but a sophist when he announces the inevitability of universal annihilation. Today this mise en sc? of death chosen and refused lies at the core of the spectacle of incoherence.

The organization of appearances aspires to the immobility of the shadow of a bird in flight. But this aspiration amounts to no more than a vain hope, bound up with the ruling class's efforts to solidify its power, of escaping from the course of history. There is, however, an important difference between myth and its fragmented, desanctified avatar, the spectacle, with respect to the way each resists the criticism of facts. The varying importance assumed in unitary systems by artisans, merchants and bankers explains the continual oscillation in these societies between the coherence of myth and the myth of coherence. With the triumph of the bourgeoisie something very different happens: by introducing history into the armoury of appearances, the bourgeois revolution historicizes appearance and thus makes the progression from the incoherence of the spectacle to the spectacle of incoherence inevitable.

In unitary societies, whenever the merchant class, with its disrespect for tradition, threatened to deconsecrate values, the coherence of myth would give way to the myth of coherence. What does this mean? What had formerly been taken for granted had suddenly to be vigorously reasserted. Loud professions of faith were heard where previously faith was so automatic as to need no stating, and respect for the great had to be preserved through recourse to the principle of absolute monarchy. I hope closer study will be given to these paradoxical interregnums of myth during which we see the bourgeoisie trying to sanctify its rise by means of a new religion and by self-ennoblement, while the nobility engages in the corollary but very different activity of gambling on an impossible transcendence. (The Fronde springs to mind - but so do the Heraclitean dialectic and Gilles de Rais.) The aristocracy had the elegance to turn its last words into a witticism; the bourgeoisie's disappearance from the scene will have but the gravity of bourgeois thought. As for the forces of revolutionary transcendence, they surely have more to win from lighthearted death than from the dead weight of survival.

There comes a time when the myth of coherence is so undermined by the criticism of facts that it cannot mutate back into a coherent myth. Appearance, that mirror in which men hide their own choices from themselves, shatters into a thousand pieces and falls into the public realm of individual supply and demand. The demise of appearances means the end of hierarchical power, that facade "with nothing behind it." The trend is clear, and leaves no room for doubt as to this final outcome. The Great Revolution was scarcely over before God's motley successors turned up at bargain prices as 'unclaimed' items on a pawnbroker's shelves. First came the Supreme Being and the Bonapartist concordat, and then, hard on their heels, nationalism, individualism, socialism, national socialism, and all the other neo-isms - not to mention the individualized dregs of every imaginable hand-me-down weltanschauung and the thousands of portable ideologies offered as 
free gifts every time someone buys a TV, an item of culture or a box of detergent. Eventually the decomposition of the spectacle entails the resort to the spectacle of decomposition. It is in the logic of things that the last actor should film his own death. As it happens, the logic of things is the logic of what can be consumed, and sold as it is consumed. Pataphysics, sub-Dada, and the mise en scène of impoverished everyday life line the road that leads us with many a twist and turn to the last graveyards.

\section{2}

The development of the drama as a literary genre cannot but throw light on the question of the organization of appearances. After all, a play is the simplest form of the organization of appearances, and a prototype for all more sophisticated forms. As religious plays designed to reveal the mystery of transcendence to men, the earliest theatrical forms were indeed the organization of appearances of their time. And the process of secularization of the theatre supplied the models for later, spectacular stage management. Aside from the machinery of war, all machines of ancient times originated in the needs of the theatre. The crane, the pulley and other hydraulic devices started out as theatrical paraphernalia; it was only much later that they revolutionized production relations. It is a striking fact that no matter how far we go back in time the domination of the earth and of men seems to depend on techniques which serve the purposes not only of work but also of illusion.

The birth of tragedy was already a narrowing of the arena in which primitive men and gods had held their cosmic dialogue. It meant a distancing, a putting in parentheses, of magical participation. This was now organized in accordance with a refraction of the principles of initiation, and no longer involved the rites themselves. What emerged was a spectaculum, a thing seen, while the gradual relegation of the gods to the role of mere props presaged their eventual eviction from the social scene as a whole. Once mythic relationships have been dissolved by secularizing tendencies, tragedy is superseded by drama. Comedy is a good indicator of this transition: with all the vigour of a completely new force, its corrosive humour devastates tragedy in its dotage. Molière's Don Juan and the parody of Handel in John Gay's Beggar's Opera bear sufficiently eloquent testimony on this score.

With the advent of drama human society replaces the gods on the stage. Now, although it is true that nineteenth-century theatre was merely one form of entertainment among others, we must not let this obscure the much more important fact that during this period theatre left the theatre, so to speak, and colonized the entire social arena. The cliché which likens life to a drama seems to evoke a fact so obvious as to need no discussion. So widespread is the confusion between play-acting and life that it does not even occur to us to wonder why it exists. Yet what is 'natural' about the fact that I stop being myself a hundred times a day and slip into the skin of people whose concerns and importance I have really not the slightest desire to know about? Not that I might not choose to be an actor on occasion - to play a role for diversion or pleasure. But this is not the type of role-playing I have in mind. The actor supposed to play a condemned man in a realist play is at perfect liberty to remain himself: herein lies, in fact, the paradox of fine acting. But this freedom that he enjoys is contingent upon the fact that this "condemned man" is in no danger of feeling a real hangman's noose about his neck. The roles we play in everyday life, on the other hand, soak into the individual, preventing him from being what he really is and what 
he really wants to be. They are nuclei of alienation embedded in the flesh of direct experience. The function of such stereotypes is to dictate to each person on an individual, even 'intimate', level the same things which ideology imposes collectively.

The immanent conditioning of religion has been replaced by partial conditioning in many areas, for now Power has to call upon a great many minor forms of brainwashing in its vain attempt to find methods of control as effective as the law and order of old. This means that prohibitions and lies have been personalised, and bear down hard on each individual so as to confine him within some abstract mould. It also means that from one point of view - from the point of view of government - progress in human knowledge improves the mechanisms of alienation: the more man views himself through the eyes of officialdom, the greater his alienation. Science provides a rationale for the police. It teaches how much people can be tortured without dying, and above all to what degree a person may be turned into a héautontimorouménos a dutiful self-torturer. It teaches how to become a thing while still retaining a human appearance - and this in the name of a certain appearance of humanity.

It is not through the dissemination of ideas that cinema, and its personalised form, television, win the battle for our minds. Their influence works in quite a different way. An actor on the stage impresses the audience by the general orientation of his movements and by the conviction with which he delivers his lines; on the big or little screen, the same character is broken down into a sequence of exact details each of which affects the spectator in a separate and subtle way. What we have here is a school of gesture, a lesson in dramatic art in which a particular facial expression or motion of the hand supplies thousands of viewers with a supposedly adequate way of expressing particular feelings, wishes, and so on. Thus the still rudimentary technology of the image teaches the individual to model his existential attitudes on the complete portraits of him assembled by the psychosociologists. His most personal tics and idiosyncrasies become the means by which Power integrates him into its schemata. The poverty of everyday life reaches it nadir by being choreographed in this way. Just as the passivity of the consumer is an active passivity, so the passivity of the spectator lies in his ability to assimilate roles and play them according to official norms. The repetition of images and stereotypes offers a set of models from which everyone is supposed to choose a role. The spectacle is a museum of images, a showroom of stick figures.

Stereotypes are debased forms of the old ethical categories: knight, saint, sinner, hero, traitor, vassal, plain man, etc. The images which drew their effectiveness within the mythic system of appearances from their qualitative force work in the context of spectacular appearances solely by virtue of the frequency of their reproduction as factors of conditioning: slogans, photos, stars, catchwords, etc. As we have seen, the technical reproduction of magical relationships such as religious faith or identification resulted eventually in the dissolution of magic. Coupled with the demise of the great ideologies, this development precipitated the chaos of stereotypes and roles. Hence the new demands placed upon the spectacle.

Real events come to us as one-dimensional scripts. We get their form, never their substance. And even their form is more or less clear according to how often it is repeated and according to its position in the structure of appearances. For as an organised system appearances are a vast filing cabinet in which events are broken up, isolated from one another, labelled and arbitrarily classified: Crimes of Passion, Political Affairs, Business Section, From the Police Blotter, 
Eating Out, etc, etc. An old lady is killed by a kid on the Boulevard St Germain. What are we told by the press? We are given a pre-established scenario designed to arouse pity, indignation, disgust, whatever. The event is broken down into abstract components which are really just cliches: youth, delinquency, crime in the streets, law and order, etc. Image, photo, style - all are fabricated and co-ordinated according to the permutations dispensed by an automatic vending machine of readymade explanations and predetermined emotions. Real people reduced to roles serve as bait: the Boston Strangler, the Prince of Wales, Brigitte Bardot, Norman Mailer - they all make love, get divorced, think thoughts and pick their noses for thousands of people. The dissemination of prosaic details invested with significance by the spectacle results in the proliferation of inconsistent roles. The husband who kills his wire s lover competes for attention with the Pope on his deathbed, and Mick Jagger's underpants are on a par with Mao's cap. It's all one, everything is equivalent to everything else, in the perpetual spectacle of incoherence. The fact is that the structures of the spectacle are in crisis, because so many balls have to be kept in the air at the same time. The spectacle has to be everywhere, so it becomes diluted and self-contradictory. The old, ever-serviceable Manichaean relationship is tending to disappear: the spectacle is not beyond good and evil, it falls short of them. The surrealists were quite mistaken when, in 1930, they hailed the act of the exhibitionist as subversive. They failed to see that in the sphere of morality the spectacle needs spicy items of this kind to keep on going. The surrealists' enthusiasm here was really no different from that of the gutter press. The media need scandal just as they need black humour and cynicism. Real scandal consists in the rejection and sabotage of the spectacle - something which Power can postpone only by giving the structures of appearance a drastic facelift. Perhaps this will turn out to have been the function of structuralism. But poverty, fortunately, cannot be mitigated by its extension to new fields. The spectacle's degeneration is in the nature of things, and the dead weight which enforces passivity is bound to lighten. Roles are eroded by the resistance put up by lived experience, and spontaneity will eventually lance the abscess of inauthenticity and pseudo-activity. 


\section{Chapter 15. Roles}

Stereotypes are the dominant images of a period, the images of the dominant spectacle. The stereotype is the model of the role; the role is a model form of behaviour. The repetition of an attitude creates a role; the repetition of a role creates a stereotype. The stereotype is an objective form into which people are integrated by means of the role. Skill in playing and handling roles determines rank in the spectacular hierarchy. The degeneration of the spectacle brings about the proliferation of stereotypes and roles, which by the same token become risible, and converge dangerously upon their negation, i.e., spontaneous actions $(1,2)$. Access to the role occurs by means of identification. The need to identify is more important to Power's stability than the models identified with. Identification is a pathological state, but only accidental identifications are officially classed as "mental illness." Roles are the bloodsuckers of the will to live (3). They express lived experience, yet at the same time they reify it. They also offer consolation for this impoverishment of life by supplying a surrogate, neurotic gratification. We have to break free of roles by restoring them to the realm of play (4). A role successfully adopted ensures promotion in the spectacular hierarchy, the rise from a given rank to a higher one. This is the process of initiation, as manifested notably in the cult of names and the use of photography. Specialists are those initiates who supervise initiation. The always partial expertise of specialists is a component part of the systematic strategy of Power, Power which destroys us even as it destroys itself (5). The degeneration of the spectacle makes roles interchangeable. The proliferation of unreal changes creates the preconditions for a sole and real change, a truly radical change. The weight of inauthenticity finally provokes a violent and quasi-biological reaction from the will to live (6).

1

Our efforts, our boredom, our defeats, the absurdity of our actions all stem most of the time from the imperious necessity in our present situation of playing hybrid parts, parts which appear to answer our desires, but which are really antagonistic to them. "We would live," says Pascal, "according to the ideas of others; we would live an imaginary life, and to this end we cultivate appearances. Yet in striving to beautify and preserve this imaginary being we neglect everything authentic." This was an original thought in the seventeenth century; at a time when the system of appearances was still hale, its coming crisis was apprehended only in the inhibitive flashes of the most lucid. Today, amidst the decomposition of all values, Pascal's observation states only what is obvious to everyone. By what magic do we attribute the liveliness of human passions to lifeless forms? Why do we succumb to the seduction of borrowed attitudes? What are roles?

Is what drives people to seek power the very weakness to which Power reduces them? The tyrant is irked by the duties the subjection of his people imposes on him. The price he pays for the divine consecration of his authority over men is perpetual mythic sacrifice, a permanent humility before God. The moment he quits God's service, he no longer 'serves' his people and his people are immediately released from their obligation to serve him. What vox populi, vox dei 
really means is: "What God wants, the people want." Slaves are not willing slaves for long if they are not compensated for their submission by a shred of power: all subjection entails the right to a measure of power, and there is no such thing as power that does not embody a degree of submission. This is why some agree so readily to be governed. Wherever it is exercised, on every rung of the ladder, power is partial, not absolute. It is thus ubiquitous, but ever open to challenge.

The role is a consumption of power. It locates one in the representational hierarchy, and hence in the spectacle: at the top, at the bottom, in the middle but never outside the hierarchy, whether this side of it or beyond it. The role is thus the means of access to the mechanism of culture: a form of initiation. It is also the medium of exchange of individual sacrifice, and in this sense performs a compensatory function. And lastly, as a residue of separation, it strives to construct a behavioural unity; in this aspect it depends on identification.

\section{2}

In a restrictive sense, the expression "to play a role in society" clearly implies that roles are a distinction reserved for a chosen few. Roman slaves, medieval serfs, agricultural day-labourers, proletarians brutalized by a thirteen-hour day - the likes of these do not have roles, or they have such rudimentary ones that 'refined' people consider them more animals than men. There is, after all, such a thing as poverty founded on exclusion from the poverty of the spectacle. By the nineteenth century, however, the distinction between good worker and bad worker had begun to gain ground as a popular notion, just as that between master and slave had been vulgarized, along with Christ, under the earlier, mythic system. It is true that the spread of this new idea was achieved with less effort, and that it never acquired the importance of the master-slave idea (although it was significant enough for Marx to deem it worthy of his derision). So, just like mythic sacrifice, roles have been democratized. Inauthenticity is a right of man; such, in a word, is the triumph of socialism. Take a thirty-five-year-old man. Each morning he takes his car, drives to the office, pushes papers, has lunch in town, plays pool, pushes more papers, leaves work, has a couple of drinks, goes home, greets his wife, kisses his children, eats his steak in front of the TV, goes to bed, makes love, and falls asleep. Who reduces a man's life to this pathetic sequence of clichés? A journalist? A cop? A market researcher? A socialist-realist author? Not at all. He does it himself, breaking his day down into a series of poses chosen more or less unconsciously from the range of dominant stereotypes. Taken over body and consciousness by the blandishments of a succession of images, he rejects authentic satisfaction and espouses a passionless asceticism: his pleasures are so mitigated, yet so demonstrative, that they can only be a facade. The assumption of one role after another, provided he mimics stereotypes successfully, is titillating to him. Thus the satisfaction derived from a well-played role is in direct proportion to his distance from himself, to his self-negation and self-sacrifice.

What power masochism has! Just as others were Count of Sandomir, Palatine of Smirnoff, Margrave of Thorn, Duke of Courlande, so he invests his poses as driver, employee, superior, subordinate, colleague, customer, seducer, friend, philatelist, husband, paterfamilias, viewer, citizen with a quite personal majesty. And yet such a man cannot be entirely reduced to the idiotic machine, the lethargic puppet, that all this implies. For brief moments his daily life must generate an energy which, if only it were not rechannelled, dispersed and squandered in roles, would suffice to overthrow the world of survival. Who can gauge the striking-power of an impassioned 
daydream, of pleasure taken in love, of a nascent desire, of a rush of sympathy? Everyone seeks spontaneously to extend such brief moments of real life; everyone wants basically to make something whole out of their everyday life. But conditioning succeeds in making most of us pursue these moments in exactly the wrong way by way of the inhuman with the result that we lose what we most want at the very moment we attain it.

Stereotypes have a life and death of their own. Thus an image whose magnetism makes it a model for thousands of individual roles will eventually crumble and disappear in accordance with the laws of consumption, the laws of constant novelty and universal obsolescence. So how does spectacular society find new stereotypes? It finds them thanks to that injection of real creativity which prevents some roles from conforming to ageing stereotypes (rather as language gets a new lease on life through the assimilation of popular forms). Thanks, in other words, to that element of play which transforms roles.

To the extent that it conforms to a stereotype, a role tends to congeal, to take on the static nature of its model. Such a role has neither present, nor past, nor future, because its time resembles exposure time, and is, so to speak, a pause in time: time compressed into the dissociated spacetime which is that of Power. (Here again we see the truth of the argument that Power's strength lies in its facility in enforcing both actual separation and false union.) The timeless moment of the role may be compared to the cinematic image, or rather to one of its elements, to one frame, to one image in the series of images of minimally varying predetermined attitudes whose reproduction constitutes a shot. In the case of roles reproduction is ensured by the rhythms of the advertising media, whose power of dissemination is the precondition for a role's achievement of the status of a stereotype (Monroe, Sagan, Dean). No matter how much or how little limelight a given role attains in the public eye, however, its prime function is always that of social adaptation, of integrating people into the well policed universe of things. Which is why there are hidden cameras always ready to catapult the most pedestrian of lives into the spotlight of instant fame. Bleeding hearts fill columns, and superfluous body hair becomes an affair of Beauty. When the spectacle battening on to everyday life takes a pair of unhappy lovers and mass-markets them as Tristan and Isolde, sells a tattered derelict as a piece of nostalgia, or makes a drudging housewife into a good fairy of the kitchen, it is already way ahead of anything modern art can dream up. It was inevitable, perhaps, that people would end up modelling themselves on collages of smiling spouses, crippled children and do-it-yourself geniuses. At any rate we have reached that point and such ploys always pay off. On the other hand the spectacle is fast approaching a saturation point, the point immediately prior to the eruption of everyday reality. For roles now operate on a level perilously close to their own negation: already the average failure is hard put to it to play his role properly, and some maladjusted people refuse their roles altogether. As it falls apart, the spectacular system starts scraping the barrel, drawing nourishment from the lowest social strata. It is forced, in fact, to eat its own shit. Thus tone-deaf singers, talent-free artists, reluctant laureates and pallid stars of all kinds emerge periodically to cross the firmament of the media, their rank in the hierarchy being determined by the regularity with which they achieve this feat.

Which leaves the hopeless cases those who reject all roles and those who develop a theory and practice of this refusal. From such maladjustment to spectacular society a new poetry of real experience and a reinvention of life are bound to spring. The deflation of roles precipitates the 
decompression of spectacular time in favour of lived space-time. What is living intensely if not the mobilization and redirection of the current of time, so long arrested and lost in appearances? Are not the happiest moments of our lives glimpses of an expanded present that rejects Power's accelerated time which dribbles away year after year, for as long as it takes to grow old?

\section{Identification}

The principle of Szondi's test is well known. The patient is asked to choose, from forty-eight photographs of people in various types of paroxystic crisis, those which evoke sympathy in him and those which evoke aversion. The subject invariably prefers those faces expressing instinctual feelings which he accepts in himself, and rejects those expressing ones which he represses. The results enable the psychiatrist to draw up an instinctual profile of his patient which helps him decide whether to discharge him or send him to the air-conditioned crematorium known as a mental hospital.

Consider now the needs of consumer society, a society in which man's essence is to consume to consume Coca-Cola, literature, ideas, emotions, architecture, TV, power, etc. Consumer goods, ideologies, stereotypes all play the part of photos in a gigantic version of Szondi's test in which each of us is supposed to take part, not merely by making a choice, but by a commitment, by practical activity. This society's need to market objects, ideas and model forms of behaviour calls for a decoding centre where an instinctual profile of the consumer can be constructed to help in product design and improvement, and in the creation of new needs liable to increase consumption. Market research, motivation techniques, opinion polls, sociological surveys and structuralism may all be considered a part of this project, no matter how anarchic and feeble their contributions may be as yet. The cyberneticians can certainly supply the missing co-ordination and rationalization if they are given the chance.

At first glance the main thing would seem to be the choice of the "consumable image." The housewife-who-uses-Fairy-Snow is different and the difference is measured in profits from the housewife-who-uses-Tide. The Labour voter differs from the Conservative voter, and the Communist from the Christian, in much the same way. But such differences are increasingly hard to discern. The spectacle of incoherence ends up putting a value on the vanishing point of values. Eventually, identification with anything at all, like the need to consume anything at all, becomes more important than brand loyalty to a particular type of car, idol, or politician. The essential thing, after all, is to alienate people from their desires and pen them in the spectacle, in the occupied zone. It matters little whether people are good or bad, honest or criminal, left-wing or right-wing: the form is irrelevant, just so long as they lose themselves in it. Let those who cannot identify with Khrushchev identify with Yevtushenko; this should cover everyone but hooligans and we can deal with them. And indeed it is the third force alone that has nothing to identify with no enemy, no pseudo-revolutionary leader. The third force is the force of identity that identity in which everyone recognizes and discovers himself. There, at least, no one makes decisions for me, or in my name; there my freedom is the freedom of all.

There is no such thing as mental illness. It is merely a convenient label for grouping and isolat-

ing cases where identification has not occurred properly. Those whom Power can neither govern 
nor kill, it taxes with madness. The category includes extremists and megalomaniacs of the role, as well as those who deride roles or refuse them. It is only the isolation of such individuals which condemns them, however. Let a General identify with France, with the support of millions of voters, and an opposition immediately springs up which seriously seeks to rival him in his lunacy. Horbiger's attempt to invent a Nazi physics met with a similar kind of success. General Walker was taken seriously when he drew a distinction between superior, white, divine and capitalist man on the one hand, and black, demoniacal, communist man on the other. Franco would meditate devoutly and beg God for guidance in oppressing Spain. Everywhere in the world are leaders whose cold frenzy lends substance to the thesis that man is a machine for ruling. True madness is a function not of isolation but of identification.

The role is the self-caricature which we carry about with us everywhere, and which brings us everywhere face to face with an absence. An absence, though, which is structured, dressed up, prettified. The roles of paranoiac, schizophrenic or psychopath do not carry the seal of social usefulness; in other words, they are not distributed under the label of power, as are the roles of cop, boss, or military officer. But they do have a utility in specified places in asylums and prisons. Such places are museums of a sort, serving the double purpose, from Power's point of view, of confining dangerous rivals while at the same time supplying the spectacle with needed negative stereotypes. For bad examples and their exemplary punishment add spice to the spectacle and protect it. If identification were maximized through increased isolation, the ultimate falseness of the distinction between mental and social alienation would soon become clear.

At the opposite extreme from absolute identification is a particular way of putting a distance between the role and one's self, a way of establishing a zone of free play. This zone is a breeding place of attitudes disruptive of the spectacular order. Nobody is ever completely swallowed up by a role. Even turned on its head, the will to live retains a potential for violence always capable of carrying the individual away from the path laid down for him. One fine morning, the faithful lackey, who has hitherto identified completely with his master, leaps on his oppressor and slits his throat. For he has reached that point where his right to bite like a dog has finally aroused his desire to strike back like a human being. Diderot has described this moment well in Rameau's Nephew and the case of the Papin sisters illustrates it even better. The fact is that identification, like all manifestations of inhumanity, has its roots in the human. Inauthentic life feeds on authentically felt desires. And identification through roles is doubly successful in this respect. In the first place it co-opts the pleasure to be derived from metamorphoses, from putting on masks and going about in different disguises. Secondly, it appropriates mankind's ancient love of mazes, the love of getting lost solely in order to find one's way again: the pleasure of the derive. In this way roles also lay under contribution the reflex of identity, the desire to find the richest and truest part of ourselves in other people. The game ceases to involve play: it petrifies because the players can no longer make up the rules. The quest for identity degenerates into identification.

Let us reverse the perspective for a moment. A psychiatrist tells us that "Recognition by society leads the individual to expend his sexual drives on cultural goals, and this is the best way for him to defend himself against these drives." Read: the aim of roles is to absorb vital energies, to reduce erotic energy by ensuring it permanent sublimation. The less erotic reality there is, the more the sexualized forms appearing in the spectacle. Roles Reich would say 'armouring' guarantee orgastic impotence. Conversely, true pleasure, joie de vivre and orgastic potency shatter body armour and roles. If individuals could stop seeing the world through the eyes of the powers-thatbe, and look at it from their own point of view, they would have no trouble discerning which 
actions are really liberating, which moments are lightning flashes in the dark night of roles. Real experience can illuminate roles can $\mathrm{x}$-ray them, so to speak in such a way as to retrieve the energy invested in them, to extricate the truth from the lies. This task is at once individual and collective. Though all roles alienate equally, some are more vulnerable than others. It is easier to escape the role of a libertine than the role of a cop, executive or rabbi. A fact to which everyone should give a little thought.

\section{Compensation}

The ultimate reason why people come to value roles more highly than their own lives is that their lives are priceless. What this means, in its ambiguity, is that life cannot be priced, cannot be marketed; and also that such riches can only be described according to the spectacle's categories as intolerable poverty. In the eyes of consumer society poverty is whatever cannot be brought down to terms of consumption. From the spectacular point of view the reduction of man to consumer is an enrichment: the more things he has, the more roles he plays, the more he is. So it is decreed by the organization of appearances. But, from the point of view of lived reality, all power so attained is paid for by the sacrifice of true self-realization. What is gained on the level of appearances is lost on the level of being and becoming.

Thus lived experience always furnishes the raw material of the social contract, the coin in which the entry fee is paid. Life is sacrificed, and the loss compensated by means of accomplished prestidigitation in the realm of appearances. The more daily life is thus impoverished, the greater the attraction of inauthenticity, and vice versa. Dislodged from its essential place by the bombardment of prohibitions, limitations and lies, lived reality comes to seem so trivial that appearances become the centre of our attention, until roles completely obscure the importance of our own lives. In an order of things, compensation is the only thing that gives a person any weight. The role compensates for a lack: ultimately, for the lack of life; more immediately, for the lack of another role. A worker conceals his prostration beneath the role of foreman, and the poverty of this role itself beneath the incomparably superior image of a late-model car. But every role is paid for by self-injury (overwork, the renunciation of 'luxuries', survival, etc.). At best it is an ineffective plug for the gaping wound left by the vampirization of the self and of real life. The role is at once a threat and a protective shield. Its threatening aspect is only felt subjectively, however, and does not exist officially. Officially, the only danger lies in the loss or devaluation of the role: in loss of honour, loss of dignity, or (happy phrase!) loss of face. This ambiguity accounts to my mind for people's addiction to roles. It explains why roles stick to our skin, why we give up our lives for them. They impoverish real experience but they also protect this experience from becoming conscious of its impoverishment. Indeed, so brutal a revelation would probably be too much for an isolated individual to take. Thus roles partake of organized isolation, of separation, of false union, while compensation is the depressant that ensures the realization of all the potentialities of inauthenticity, that gets us high on identification.

Survival and its protective illusions form an inseparable whole. The end of survival naturally entails the disappearance of roles (although there are some dead people whose names are linked to stereotypes). Survival without roles is to be officially dead. Just as we are condemned to survival, so we are condemned to "keep up appearances" in the realm of inauthenticity. Armouring inhibits freedom of gesture but also deadens blows. Beneath this carapace we are completely 
vulnerable. But at least we can still play "let's pretend" we still have a chance to play roles off against one another.

Rosanov's approach is not a bad one: "Externally, I decline. Subjectively, I am quite indeclinable. I don't agree. I'm a kind of adverb." In the end, of course, the world must be modelled on subjectivity: then I will 'agree' with myself in order to 'agree' with others. But, right now, to throw out all roles like a bag of old clothes would amount to denying the fact of separation and plunging into mysticism or solipsism. I am in enemy territory, and the enemy is within me. I don't want him to kill me, and the armour of roles gives me a measure of protection. I work, I consume, I know how to be polite, how to avoid aggravation, how to keep a low profile. All the same, this world of pretence has to be destroyed, which is why it is a shrewd course to let roles play each other off. Seeming to have no responsibility is the best way of behaving responsibly toward oneself. All jobs are dirty so do them dirtily! All roles are lies, but leave them alone and they'll give each other the lie! I love the arrogance of Jacques Vache when he writes: "I wander from ruins to village with my monocle of Crystal and a disturbing theory of painting. I have been in turn a lionized author, a celebrated pornographic draftsman and a scandalous cubist painter. Now I am going to stay at home and let others explain and debate my personality in the light of the above mentioned indications." My only responsibility is to be absolutely honest with those who are on my side, those who are true partisans of authentic life.

The more detached one is from a role, the easier it becomes to turn it against the enemy. The more effectively one avoids the weight of things, the easier it is to achieve lightness of movement. Comrades care little for forms. They argue openly, confident in the knowledge that they cannot inflict wounds on each other. Where communication is genuinely sought, misunderstandings are no crime. But if you accost me armed to the teeth, understanding agreement only in terms of a victory for you, then you will get nothing out of me but an evasive pose, and a formal silence intended to indicate that the discussion is closed. For interchange on the basis of contending roles is useless a priori. Only the enemy wants to fight on the terrain of roles, according to the rules of the spectacle. It is hard enough keeping one's phantoms at arm's length: who needs 'friendships' which put us back on the same footing? Would that biting and barking could wake people up to the dog's life roles force them to live wake them up to the importance of their selves!

Fortunately, the spectacle of incoherence is obliged to introduce an element of play into roles. Its levelling of all ethical distinctions makes it impossible to take seriously. The playful approach to roles leaves them floating in the sea of its indifference. This accounts for the rather unhappy efforts of our reorganizers of appearances to increase the playful element (TV game shows, etc.), to press flippancy into the service of consumption. The disintegration of appearances tends to foster distancing from roles. Some roles, being dubious or ambiguous, embody their own selfcriticism. The spectacle is destined eventually for reconversion into a collective game. Daily life, seizing whatever means it has to hand, will establish the preconditions for this game's neverending expansion.

\section{Initiation}

As it seeks to safeguard the poverty of survival by loudly protesting against it, the compensatory tendency bestows upon each individual a certain number of formal possibilities of participating in the spectacle a sort of permit for the scenic representation of one or more slices of 
(private or public) life. Just as God used to bestow grace on all men, leaving each free to choose salvation or damnation, so modern social organization accords everyone the right to be a success or a failure in the social world. But whereas God appropriated human subjectivity in one fell swoop, the bourgeoisie commandeers it by means of a series of partial alienations. In one sense, therefore, there is progress here: subjectivity, which was nothing, becomes something; it attains its own truth, its mystery, its passions, its rationality, its rights. But this official recognition is bought at the price of its subdivision into components which are graded and pigeonholed according to Power's norms. Subjectivity attains objective form as stereotypes, by means of identification. In the process it has to be broken up into would-be-absolute fragments and pathetically reduced (witness the Romantics' grotesque treatment of the self, and the antidote for it, humour).

I possess badges of power, therefore I am. In order to be someone the individual must pay things their due. He must keep his roles in order, polish them up, enter into them repeatedly, and initiate himself little by little until he qualifies for promotion in the spectacle. The conveyor belts called schools, the advertising industry, the conditioning mechanisms inseparable from any Order - all conspire to lead the child, the adolescent and the adult as painlessly as possible into the big family of consumers.

There are different stages of initiation. Recognized social groups do not all enjoy the same measure of power, nor is that measure equally distributed within each group. It is a long way, in hierarchical terms, from the boss to his workers, from the star to his fans, or from the politician to his supporters. Some groups have a much more rigid structure than others. But all are founded on the illusion of participation shared by every group member whatever his rank. This illusion is fostered through meetings, insignia, the distribution of minor 'responsibilities', etc. The spurious solidarities maintained by such expedients are often friable. This boyscout mentality is frighteningly pervasive, and it throws up its own stereotypes, its own martyrs, heroes, models, geniuses, thinkers, good niggers, great successes e.g., Tania, Cienfuegos, Brando, Dylan, Sartre, a national darts champion, Lin Piao. (The reader is asked to assign each to the appropriate category...)

Can the collectivization of roles successfully replace the quondam power of the old ideologies? It has to be remembered that Power stands or falls with the organization of appearances. The fission of myth into particles of ideology has produced roles as fallout. The poverty of power now has no means of self-concealment aside from its lie-in-pieces. The prestige of a film star, a head of a family, or a chief executive is not worth a wet fart. Nothing can escape the effects of this nihilistic process of decomposition except its transcendence. Even a technocratic victory preventing this transcendence can only amount to the condemnation of people to meaningless activity, to rites of initiation leading nowhere, to unrewarded sacrifice, to enrollment without roles, $\mathrm{t}$ o specialization.

The specialist is, indeed, an adumbration of just such a chimerical being, cog, mechanical thing, housed in the rationality of a perfect social order of zombies. He turns up everywhere among politicians, among hijackers. Specialization is in a sense the science of roles, the science of endowing appearances with the éclat formerly bestowed by nobility, wit, extravagance or wealth. The specialist does more than this, however, for he enrolls himself in order to enroll others. He is the vital link between the techniques of production and consumption and the technique of spectacular representation. Yet he is, so to speak, an isolated link a monad. Knowing everything about a small area, he enlists others to produce and consume within the confines of this area so that he himself may receive a surplus-value of power and increase the significance of his own hierarchical image. He knows, if need be, how to give up a multitude of roles for one only, how 
to concentrate his power instead of spreading it around, how to make his life unilinear. When he does this he becomes a manager. His misfortune is that the sphere within which he exercises power is always too restricted, too partial. He is like the gastro-enterologist who cures a stomach but poisons the rest of the body in the process. Naturally, the importance of the group which he holds in thrall can allow him the illusion of power, but the anarchy is such, the clash of contradictory competing interests so violent, that he must eventually realize how powerless he really is. Just as heads of state with the power to unleash thermonuclear war contrive to paralyze each other, so specialists, by working at cross-purposes, construct and (in the last analysis) operate a gigantic machine Power, social organization which dominates them all and oppresses them in varying degrees according to their importance as cogs. They construct and operate this machine blindly, because it is simply the aggregate of their crossed purposes. We may expect, therefore, that in the case of most specialists the sudden consciousness of such a disastrous passivity, a passivity in which they have invested so much effort, will eventually fling them all the more energetically in the direction of an authentic will to live. It is also predictable that others among them, those who have been longer or more intensely exposed to the radiation of authoritarian passivity, will follow the example of the officer in Kafka's Penal Colony and perish along with the machine, tormented to the end by its last spasms. Every day the crossed purposes of the powerful make and unmake the tottering majesty of Power. We have seen with what results. Let us now try to imagine the glacial nightmare into which we would be plunged were the cyberneticians able so to co-ordinate their efforts as to achieve a rational organization of society, eliminating or at any rate reducing the effects of crossed purposes. They would have no rivals for the Nobel Prize, save perhaps the proponents of thermonuclear suicide.

The widespread use of name and photograph, as in what are laughingly referred to as 'identification' papers, is rather obviously tied up with the police function in modern societies. But the connection is not merely with the vulgar police work of search, surveillance, harassment, torture and murder incorporated. It also involves much more occult methods of maintaining law and order. The frequency with which an individual's name or image passes through the visual and oral channels of communication is an index of that individual's rank and category. It goes without saying that the name most often uttered in a neighbourhood, town, country, or in the world has a powerful fascination. Charted statistically for any given time and place, this information would supply a perfect relief map of Power.

Historically, however, the degeneration of roles goes hand in hand with the increasing meaninglessness of names. The aristocrat's name crystallizes the mystery of birth and title. In consumer society the spectacular exposure of the name of a Bernard Buffet serves to transform a very ordinary talent into a famous painter. The manipulation of names fabricates leaders in the same way as it sells shampoo. But this also means that a famous name is no longer the attribute of the one who bears it. The name 'Buffet' does not designate anything except a thing and a pig in a poke. It is a fragment of power.

I laugh when I hear the humanists whining about the reduction of people to ciphers. What makes them think the destruction of men complete with tricked-up names is any less inhuman than their destruction as a set of numbers? I have already said that the obscure antagonism between the would-be progressives and the reactionaries boils down to this: should people be smashed by punishments or by rewards? As for the reward of celebrity, thanks for nothing! 
In any case, it is things that have names nowadays, not people. To reverse the perspective, however, it makes me happy to think that what I am cannot be reduced to a name. My pleasure is nameless: those all too rare moments when I act for myself afford no handhold for external manipulation of whatever kind. It is only when I accede to the dispossession of my self that I risk petrification amidst the names of the things which oppress me. This is the context in which to grasp the full meaning of Albert Libertad's burning of his identification papers. Such an act echoed much later by the black workers of Johannesburg is more than a rejection of police control: it is a way of giving up one name so as to have the pick of a thousand. Such is the superb dialectic of the change in perspective: since the powers-that-be forbid me to bear a name which is as it was for the feudal lord a true emanation of my strength, I refuse to be called by any name, and suddenly beneath the nameless I discover the wealth of real life, inexpressible poetry, the antechamber of transcendence. I enter the nameless forest where Lewis Carroll's gnat explains to Alice: "If the governess wanted to call you for your lessons, she would call out 'Come here ', and there she would have to leave off, because there wouldn't be any name for her to call, and of course you wouldn't have to go, you know." The blissful forest of radical subjectivity.

Giorgio de Chirico, to my mind, also has an admirably lucid knowledge of the way to Alice's forest. What holds for names holds too for the representation of the face. The photograph is the expression par excellence of the role, of the pose. It imprisons the soul and offers it up for inspection this is why a photograph is always sad. We examine it as we examine an object. And, true enough, to identify oneself with a range of facial expressions, no matter how broad a range, is a form of self-objectification. The God of the mystics at least had the good sense to avoid this trap. But let us get back to Chirico a near contemporary of Libertad's. (Power, if only it were human, would be proud of the number of potential encounters it has successfully prevented.) The blank faces of Chirico's figures are the perfect indictment of inhumanity. His deserted squares and petrified backgrounds display man dehumanized by the things he has made things which, frozen in an urban space crystallizing the oppressive power of ideologies, rob him of his substance and suck his blood. (I forget who speaks somewhere of vampiric landscapes; Breton, perhaps.) More than this, the absence of facial features seems to conjure up new faces, to materialize a presence capable of investing the very stones with humanity. For me this ghostly presence is that of collective creation: because they have no one's face, Chirico's figures evoke everyone.

In striking contrast to the fundamental tendency of modern sculpture, which goes to great lengths to express its own nothingness and concocts a semiology on the basis of its nullity, Chirico gives us paintings in which this absence is evoked solely as a means of intimating what lies beyond it namely, the poetry of reality and the realization of art, of philosophy, of man. As the sign of a reified world, the blank space is incorporated into the canvas at the crucial spot; the implication is that the countenance is no longer part of the representational universe, but is about to become part of everyday praxis.

One of these days the incomparable wealth of the decade between 1910 and 1920 will be clearly seen. The genius of these years, however primitive and intuitive, lay in the fact that for the first time an attempt was made to bridge the gulf between art and life. I think we may safely say that, the surrealist adventure aside, nothing was achieved in the period between the demise of this vanguard of transcendence and the inception of the situationist project. The disillusionment of the older generation which has been marking time for the last forty years, as much in the realm of art as in that of social revolution, merely reinforces this view. Dada, Malevich's white square, Ulysses, Chirico's canvasses - all impregnated the absence of man reduced to the state of a thing 
with the presence of the whole man. And today the whole man is simply the project which the majority of men harbour under the sign of a forbidden creativity.

\section{6}

In the unitary world, under the serene gaze of the gods, adventure and pilgrimage were paradigms of change in an unchanging universe. Inasmuch as this world was given for all time there was really nothing to be discovered, but revelation awaited the pilgrim, knight or wanderer at the crossroads. Actually revelation lay within each individual: the seeker would travel the world seeking it in himself, seeking it in far lands, until suddenly it would surge forth, a magical spring released by the purity of a gesture at the same place where the ill-favoured seeker would have found nothing. The spring and the castle dominate the creative imagination of the Middle Ages. The symbolic theme here is plain: beneath movement lies immutability, and beneath immutability, movement.

Wherein lies the greatness of Heliogabalus, Tamerlane, Gilles de Rais, Tristan, Perceval? In the fact that, once vanquished, they withdraw into a living God; they identify with the demiurge, abandoning their unsatisfied humanity in order to reign and die under the mask of divine awe. This death of men, which is the God of the immutable, lets life bloom under the shadow of its scythe. Our dead God weighs more heavily than the living God of old; for the bourgeoisie has not completely disposed of God, it has only contrived to air-condition his corpse. (The Romantic attitude was a reaction to the odour of that corpse's putrefaction, a disgusted wrinkling of the nostrils at the conditions imposed by survival.)

As a class rent by contradictions, the bourgeoisie founds its domination on the transformation of the world, yet refuses to transform itself. It is thus a movement wishing to avoid movement. In unitary societies the image of immutability embraced movement; in fragmentary societies change seeks to reproduce immutability: "Wars (or the poor, or slaves) will always be with us." Thus the bourgeoisie in power can tolerates change only if it is empty, abstract, cut off from the whole: partial change, changes of parts. Now although the habit of change is intrinsically subversive, it is also the main prerequisite to the functioning of consumer society. People have to change cars, fashions, ideas, etc., all the time. For if they did not, a more radical change would occur which would put an end to a form of authority that is already reduced to putting itself up for sale as parcels of power: it has to be consumed at all costs, and one of the costs is that everyone is consumed along with it. Sad to say, this headlong rush towards death, this desperate and would-be endless race deprives us of any real future: ahead lies the past, hastily disguised and projected forward in time. For decades now the selfsame 'novelties' have been turning up in the marketplace of fad and fancy, with the barest attempt to conceal their decrepitude. The same is true in the supermarket of the role. The system is confronted by the problem of how to supply a variety of roles wide enough to compensate for the loss of the qualitative force of the role as it existed in the prebourgeois era. This is a hopeless task for two reasons. In the first place, the quantitative character of roles is a limitation by definition, and inevitably engenders the demand for a conversion into quality. Secondly, the lie of renewal cannot be sustained within the poverty of the spectacle. The constant need for fresh roles forces a resort to remakes, to transparent mummery. The proliferation of trivial changes titillates the desire for real change 
but never satisfies it. Power accelerates changes in illusions, thereby hastening the eruption of reality, of radical change.

It is not just that the increasing number of roles tends to make them indistinguishable, it also triturates them and makes them ludicrous. The quantification of subjectivity has created spectacular categories for the most prosaic acts and the most ordinary attributes: a certain smile, a chest measurement, a hairstyle. Great roles are few and far between; walk-ons are a dime a dozen. Even the Ubus the Stalins, Hitlers or Mussolinis have but the palest of successors. Most of us are well acquainted with the malaise that accompanies any attempt to join a group and make contact with others. This feeling amounts to stage fright, the fear of not playing one's part properly. Only with the crumbling of officially controllable attitudes and poses will the true source of this anxiety become clear to us. For it arises not from our clumsiness in handling roles but from the loss of self in the spectacle, in the order of things. In his book Medecine et homme total, Soli, has this to say about the frightening spread of neurotic disorders: "There is no such thing as disease per se, no such thing, even, as a sick person per se: all there is is authentic or inauthentic being-in-theworld." The reconversion of the energy robbed by appearances into the will to live authentically is a function of the dialectic of appearances itself. The refusal of inauthenticity triggers a nearbiological defensive reaction which because of its violence has a very good chance of destroying those who have been orchestrating the spectacle of alienation all this time. This fact should give pause to all who pride themselves on being idols, artists, sociologists, thinkers and specialists of every kind of mise en scene. Explosions of popular anger are never accidental.

According to a Chinese philosopher, "Confluence tends towards the void. In total confluence presence stirs." Alienation extends to all human activities and dissociates them in the extreme. But by the same token it loses its own coherence and becomes everywhere more vulnerable. In the disintegration of the spectacle we see what Marx called "the new life which becomes self-aware, destroys what is already destroyed, and rejects what is already rejected." Beneath dissociation lies unity; beneath fatigue, concentrated energy; beneath the fragmentation of the self, radical subjectivity. In other words, the qualitative. But there is more to wanting to remake the world than wanting to make love to your lover.

With the weakening of the factors responsible for the etiolation of everyday life, the forces of life tend to get the upper hand over the power of roles. This is the beginning of the reversal of perspective. Modern revolutionary theory should concentrate its efforts on this area so as to open the breach that leads to transcendence. As the period of calculation and suspicion ushered in by capitalism and Stalinism draws to a close, it is challenged from within by the initial phase, based on clandestine tactics, of the era of play.

The degenerate state of the spectacle, individual experience, collective acts of refusal these supply the context for development of practical tactics for dealing with roles. Collectively it is quite possible to abolish roles. The spontaneous creativity and festive atmosphere given free rein in revolutionize moments afford ample evidence of this. When people are overtaken by joie de vivre they are lost to leadership and stage management of any kind. Only by starving the revolutionary masses of joy can one become their master: uncontained, collective pleasure can only go from victory to victory. Meanwhile it is already possible for a group dedicated to theoretical and practical actions, like the situationists, to infiltrate the political and cultural spectacle as a 
subversive force. Individually and thus in a strictly temporary way we must learn how to sustain roles without strengthening them to the point where they are detrimental to us. How to use them as a protective shield while at the same time protecting ourselves against them. How to retrieve the energy they absorb and actualize the illusory power they dispense. How to play the game of a Jacques Vache.

If your role imposes a role on others, assume this power which is not you, then set this phantom loose. Nobody wins in struggles for prestige, so don't bother with them. Down with pointless quarrels, vain discussions, forums, debates and Weeks for Marxist Thought! When the time comes to strike for your real liberation, strike to kill. Words cannot kill. Do people want to discuss things with you? Do they admire you? Spit in their faces. Do they make fun of you? Help them recognize themselves in their mockery. Roles are inherently ridiculous. Do you see nothing but roles around you? Treat them to your nonchalance, to your dispassionate wit. Play cat and mouse with them, and there is a good chance that one or two people about you will wake up to themselves and discover the prerequisites for real communication. Remember: all roles alienate equally, but some are less despicable than others. The range of stereotyped behaviour includes forms which barely conceal lived experience and its alienated demands. To my mind, temporary alliances are permissible with certain revolutionary images, to the extent that a glimmer of radicalism shines through the ideological screen which they presuppose. A case in point is the cult of Lumumba among young Congolese revolutionaries. In any case, it is impossible to go wrong so long as we never forget that the only proper treatment for ourselves and for others is to make ever more radical demands. 


\section{Chapter 16. The Fascination of Time}

People are bewitched into believing that time slips away, and this belief is the basis of time actually slipping away. Time is the work of attrition of that adaptation to which people must resign themselves so long as they fail to change the world. Age is a role, an acceleration of 'lived' time on the plane of appearances, an attachment to things.

The growth of civilization's discontents is now forcing every branch of therapeutics towards a new demonology. Just as, formerly, invocation, sorcery, possession, exorcism, black sabbaths, metamorphoses, talismans and all the rest were bound up with the suspect capacity for healing and hurting, so today (and more effectively) the apparatus for offering consolation to the oppressed medicine, ideology, compensatory roles, consumer gadgetry, movements for social change serves the oppressor and the oppressor alone. The order of things is sick: this is what our leaders would conceal at all costs. In a fine passage of The Function of the Orgasm, Wilhelm Reich relates how after long months of psychoanalytic treatment he managed to cure a young Viennese working woman. She was suffering from depression brought on by the conditions of her life and work. When she was recovered Reich sent her back home. A fortnight later she killed herself. Reich's intransigent honesty condemned him, as everyone knows, to exclusion from the psychoanalytic establishment, to isolation, delusion and death in prison: the duplicity of our neodemonologists cannot be exposed with impunity.

Those who organize the world organize both suffering and the anaesthetics for dealing with it; this much is common knowledge. Most people live like sleepwalkers, torn between the gratification of neurosis and the traumatic prospect of a return to real life. Things are now reaching the point, however, where the maintenance of survival calls for so many analgesics that the organism approaches saturation point. But the magical analogy is more apt here than the medical: practitioners of magic fully expect a backlash effect in such circumstances, and we should expect the same. It is because of the imminence of this upheaval that I compare the present conditioning of human beings to a massive bewitchment.

Bewitching of this kind presupposes a spatial network which links up the most distant objects sympathetically, according to specific laws: formal analogy, organic coexistence, functional symmetry, symbolic affiliation, etc. Such correspondences are established through the infinitely frequent association of given forms of behaviour with appropriate signals. In other words, through a generalized system of conditioning. The present vogue for loudly condemning the role of conditioning, propaganda, advertising and the mass media in modern society may be assumed to be a form of partial exorcism designed to reinforce a vaster and more essential mystification by distracting attention from it. Outrage at the gutter press goes hand in hand with subservience to the more elegant lies of posh journalism. Media, language, time these are the giant claws with which Power manipulates humanity and moulds it brutally to its own perspective. These claws are not very adept, admittedly, but their effectiveness is enormously increased by the fact that people are not aware that they can resist them, and often do not even know the extent to which they are already spontaneously doing so. 
Stalin's show trials proved that it only takes a little patience and perseverance to get a man to accuse himself of every imaginable crime and appear in public begging to be executed. Now that we are aware of such techniques, and on our guard against them, how can we fail to see that the set of mechanisms controlling us uses the very same insidious persuasiveness though with more powerful means at its disposal, and with greater persistence when it lays down the law: "You are weak, you must grow old, you must die." Consciousness acquiesces, and the body follows suit. I am fond of a remark of Artaud's, though it must be set in a materialist light: "We do not die because we have to die: we die because one day, and not so long ago, our consciousness was forced to deem it necessary."

Plants transplanted to an unfavourable soil die. Animals adapt to their environment. Human beings transform theirs. Thus death is not the same thing for plants, animals and humans. In favourable soil, the plant lives like an animal: it can adapt. Where man fails to change his surroundings, he too is in the situation of an animal. Adaptation is the law of the animal world.

According to Hans Selye, the theoretician of 'stress', the general syndrome of adaptation has three phases: the alarm reaction, the phase of resistance and the phase of exhaustion. In terms of real life he is still at the level of animal adaptation: spontaneous reactions in childhood, consolidation in maturity, exhaustion in old age. And today, the harder people try to find salvation in appearances, the more vigorously is it borne in upon them by the ephemeral and inconsistent nature of the spectacle that they live like dogs and die like bundles of hay. The day cannot be far off when men will have to face the fact that the social organization they have constructed to change the world according to their wishes no longer serves this purpose. For all this organization amounts to is a system of prohibitions preventing the creation of a higher form of organization and the use therein of the techniques of liberation and individual self-realization which have evolved throughout the history of privative appropriation, of exploitation of man by man, of hierarchical authority.

We live in a closed, suffocating system. Whatever we gain in one sphere we lose in another. Death, for instance, though quantitatively defeated by modern medicine, has re-emerged qualitatively on the plane of survival. Adaptation has been democratized, made easier for everyone, at the price of abandoning the essential project, which is the adaptation of the world to human needs.

A struggle against death exists, of course, but it takes place within the limits set by the adaptation syndrome: death is part of the cure for death. Significantly, therapeutic efforts concentrate mainly on the exhaustion phase, as though the main aim were to extend the stage of resistance as far as possible into old age. Thus the big guns are brought out only once the body is old and weak, because, as Reich understood well, any all-out attack on the attrition wreaked by the demands of adaptation would inevitably mean a direct onslaught on social organization i.e., on that which stands opposed to any transcendence of the principle of adaptation. Partial cures are preferred because they leave the overall social pathology untouched. But what will happen when the proliferation of such partial cures ends up spreading the malaise of inauthenticity to every corner of daily life? And when the essential role of exorcism and bewitchment in the maintenance of a sick society becomes plain for all to see?

The question "How old are you?" inevitably contains a reference to power. Dates themselves serve to pigeonhole and circumscribe us. Is not the passage of time always measured by reference 
to the establishment of some authority or other in terms of the years accumulated since the installation of a god, messiah, leader or conquering city? To the aristocratic mind, moreover, such accumulated time was a measure of authority: the prepotency of the lord was increased both by his own age and by the antiquity of his lineage. At his death the noble bequeathed a vitality to his heirs which drew vigour from the past. By contrast, the bourgeoisie has no past; or at any rate it recognizes none inasmuch as its fragmented power no longer depends on any hereditary principle. The bourgeoisie is thus reduced to aping the nobility: identification with forebears is sought in nostalgic fashion via the photos in the family album; identification with cyclical time, with the time of the eternal return, is feebly emulated by blind identification with a staccato succession of short spans of linear time.

This link between age and the starting-post of measurable time is not the only thing which betrays age's kinship with power. I am convinced that people's measured age is nothing but a role. It involves a speeding up of lived time in the mode of non-life on the plane, therefore, of appearances, and in accordance with the dictates of adaptation. To acquire power is to acquire 'age'. In earlier times only the 'aged' or 'elders', those old either in nobility or in experience, exercised power. Today even the young enjoy the dubious privilege of age. In fact consumer society, which invented the teenager as a new class of consumer, fosters premature senility: to consume is to be consumed by inauthenticity, nurturing appearance to the advantage of the spectacle and to the detriment of real life. The consumer is killed by the things he becomes attached to, because these things (commodities, roles) are dead.

Whatever you possess possesses you in return. Everything that makes you into an owner adapts you to the order of things makes you old. Time-which-slips-away is what fills the void created by the absence of the self. The harder you run after time, the faster time goes: this is the law of consumption. Try to stop it, and it will wear you out and age you all the more easily. Time has to be caught on the wing, in the present but the present has yet to be constructed.

We were born never to grow old, never to die. All we can hope for, however, is an awareness of having come too soon. And a healthy contempt for the future can at least ensure us a rich portion of life. 
Survival and False Opposition to It 
Survival is life reduced to economic imperatives. In the present period, therefore, survival is life reduced to what can be consumed (seventeen). Reality is giving answers to the problem of transcendence before our so-called revolutionaries have even thought of formulating this problem. Whatever is not transcended rots, and whatever is rotten cries out for transcendence. Spurious opposition, being unaware of both these tendencies, speeds up the process of decomposition while becoming an integral part of it: it thus makes the task of transcendence easier but only in the sense in which we sometimes say of a murdered man that he made his murderer's task easier. Survival is non-transcendence become unlivable. The mere rejection of survival dooms us to impotence. We have to retrieve the core of radical demands which has repeatedly been renounced by movements which started out as revolutionary (eighteen). 


\section{Chapter 17. Survival Sickness}

Capitalism has demystified survival. It has made the poverty of daily life intolerable in view of the increasing wealth of technical possibilities. Survival has become an economizing on life. The civilization of collective survival increases the dead time in individual lives to the point where the death forces are liable to carry the day over collective survival itself. The only hope is that the passion for destruction may be reconverted into a passion for life.

Up until now people have merely complied with a system of world transformation. Today the task is to make the system comply with the transformation of the world.

The organization of human societies has changed the world, and the world in changing has brought upheaval to the organization of human societies. But if hierarchical organization seizes control of nature, while itself undergoing transformation in the court of this struggle, the portion of liberty and creativity falling to the lot of the individual is drained away by the requirements of adaptation to social norms of various kinds. This is true, at any rate, so long as no generalized revolutionary moment occurs.

The time belonging to the individual in history is for the most part dead time. Only a rather recent awakening of consciousness has made this fact intolerable to us. For with its revolution the bourgeoisie does two things. On the one hand, it proves that people can accelerate world transformation, and that they can improve their individual lives (where improvement is understood in terms of accession to the ruling class, to riches, to capitalist success). But at the same time the bourgeois order nullifies the individual's freedom by interference; it increases the dead time in daily life (imposing the need to produce, consume, calculate); and it capitulates before the haphazard laws of the market, before the inevitable cyclical crises with their burden of wars and misery, and before the limitations invented by "common sense" ("You can't change human nature," "The poor will always be with us", etc.). The politics of the bourgeoisie, as of the bourgeoisie's socialist heirs, is the politics of a driver pumping the brake while the accelerator is jammed fast to the floor: the more the speed increases, the more frenetic, perilous and useless become the attempts to slow down. The helter-skelter pace of consumption is set at once by the rate of the disintegration of Power and by the imminence of the construction of a new order, a new dimension, a parallel universe born of the collapse of the Old World.

The changeover from the aristocratic system of adaptation to the "democratic" one brutally widened the gap between the passivity of individual submission and the social dynamism that transforms nature the gap between people's powerlessness and the power of new techniques. The contemplative attitude was perfectly suited to the feudal system, to a virtually motionless world underpinned by eternal gods. But the spirit of submission was hardly compatible with the dynamic vision of merchants, manufacturers, bankers and discoverers of riches - the vision of those acquainted not with the revelation of the immutable, but rather with the shifting economic world, the insatiable hunger for profit and the necessity of constant innovation. Yet wherever the bourgeoisie's action results in the popularization and valorization of the sense of transience, the sense of hope, the bourgeoisie qua power seeks to imprison people within this transitoriness. 
To replace the old theology of stasis the bourgeoisie sets up a metaphysics of motion. Although both these ideological systems hinder the movement of reality, the earlier one does so more successfully and more harmoniously than the second: the aristocratic scheme is more consistent, more unified. For to place an ideology of change in the service of what does not change creates a paradox which nothing henceforward can either conceal from consciousness or justify to consciousness. Thus in our universe of expanding technology and comfort we see people turning in upon themselves, shrivelling up, living trivial lives and dying for details. It is a nightmare where we are promised absolute freedom but granted a miserable square inch of individual autonomy - a square inch, moreover, that is strictly policed by our neighbours. A space-time of pettiness and mean thoughts.

Before the bourgeois revolution, the possibility of death in a living God lent everyday life an illusory dimension which aspired to the fullness of a multifaceted reality. You might say that humanity has never come closer to self-realization while yet confined to the realm of the inauthentic. But what is one to say of a life lived out in the shadow of a God that is dead: the decomposing God of fragmented power? The bourgeoisie has dispensed with a God by economizing on people's lives. It has also made the economic sphere into a sacred imperative and life into an economic system. This is the model that our future programmers are preparing to rationalize, to submit to proper planning - in a word, to "humanize." And, never fear, they will be no less irresponsible than the corpse of God.

Kierkegaard describes survival sickness well: "Let others bemoan the maliciousness of their age. What irks me is its pettiness, for ours is an age without passion...My life comes out all one colour." Survival is life reduced to bare essentials, to life's abstract form, to the minimum of activity required to ensure people's participation in production and consumption. The entitlement of a Roman slave was rest and sustenance. As beneficiaries of the Rights of Man we receive the wherewithal to nourish and cultivate ourselves, enough consciousness to play a role, enough initiative to acquire power and enough passivity to flaunt Power's insignia. Our freedom is the freedom to adapt after the fashion of higher animals.

Survival is life in slow motion. How much energy it takes to remain on the level of appearances! The media gives wide currency to a whole personal hygiene of survival: avoid strong emotions, watch your blood pressure, eat less, drink in moderation only, survive in good health so that you can continue playing your role. "Overwork: the executive's disease," said a recent headline in Le Monde. We must be economical with survival for it wears us down; we have to live it as little as possible for it belongs to death. In former times one died a live death, one quickened by the presence of God. Today our respect for life prohibits us from touching it, reviving it or snapping it out of its lethargy. We die of inertia, whenever the charge of death that we carry with us reaches saturation point. Unfortunately there is no branch of science that can measure the intensity of the deadly radiation that kills our daily actions. In the end, by dint of identifying ourselves with what we are not, of switching from one role to another, from one authority to another, and from one age to another, how can we avoid becoming ourselves part of that never-ending state of transition which is the process of decomposition?

The presence within life itself of a mysterious yet tangible death so misled Freud that he postulated an ontological curse in the shape of a "death instinct." This mistake of Freud's, which Reich had already pointed out, has now been clarified by the phenomenon of consumption. The three aspects of the death instinct - Nirvana, the repetition compulsion and masochism - have turned 
out to be simply three styles of domination: constraint passively accepted, seduction through conformity to custom, and mediation perceived as an ineluctable law.

As we know, the consumption of goods - which comes down always, in the present state of things, to the consumption of power - carries within itself the seeds of its own destruction and the conditions of its own transcendence. The consumer cannot and must not ever attain satisfaction: the logic of the consumable object demands the creation of fresh needs, yet the accumulation of such false needs exacerbates the malaise of people confined with increasing difficulty solely to the status of consumers. Furthermore, the wealth of consumer goods impoverishes authentic life. It does so in two ways. First, it replaces authentic life with things. Secondly, it makes it impossible, with the best will in the world, to become attached to these things, precisely because they have to be consumed, i.e., destroyed. Whence an absence of life which is ever more frustrating, a self-devouring dissatisfaction. This need to live is ambivalent: it constitutes one of those points where perspective is reversed.

In the consumer's manipulated view of things - the view of conditioning - the lack of life appears as insufficient consumption of power and insufficient self-consumption in the service of power. As a palliative to the absence of real life we are offered death on an instalment plan. A world that condemns us to a bloodless death is naturally obliged to propagate the taste for blood. Where survival sickness reigns, the desire to live lays hold spontaneously of the weapons of death: senseless murder and sadism flourish. For passion destroyed is reborn in the passion for destruction. If these conditions persist, no one will survive the era of survival. Already the despair is so great that many people would go along with the Antonin Artaud who said: "l bear the stigma of an insistent death that strips real death of all terror for me."

The individual of survival is inhabited by pleasure-anxiety, by unfulfillment: a mutilated person. Where is one to find oneself in the endless self-loss into which everything draws one? They are wanderers in a labyrinth with no centre, a maze full of mazes. Theirs is a world of equivalents. Should one kill oneself? Killing oneself, though, implies some sense of resistance: one must possess a value that one can destroy. Where there is nothing, the destructive actions themselves crumble to nothing. You cannot hurl a void into a void. "If only a rock would fall and kill me," wrote Kierkegaard, "at least that would be an expedient." I doubt if there is anyone today who has not been touched by the horror of a thought such as that. Inertia is the surest killer, the inertia of people who settle for senility at eighteen, plunging eight hours a day into degrading work and feeding on ideologies. Beneath the miserable tinsel of the spectacle there are only gaunt figures yearning for, yet dreading, Kierkegaard's "expedient," so that they might never again have to desire what they dread and dread what they desire.

At the same time the passion for life emerges as a biological need, the reverse side of the passion for destroying and letting oneself be destroyed. "So long as we have not managed to abolish any of the causes of human despair we have no right to try and abolish the means whereby people attempt to get rid of despair." The fact is that people possess both the means to eliminate the causes of despair and the power to mobilize these means in order to rid themselves of it. No one has the right to ignore the fact that the sway of conditioning accustoms them to survive on one hundredth of their potential for life. So general is survival sickness that the slightest concentration of lived experience could not fail to unite the largest number of people in a common will to live. The negation of despair would of necessity become the construction of a new life. The rejection of economic logic (which only economizes on life) would of necessity entail the death of economics and carry us beyond the realm of survival. 


\section{Chapter 18. Spurious Opposition}

There comes a moment of transcendence that is historically defined by the strength and weakness of Power; by the fragmentation of the individual to the point where he or she is a mere monad of subjectivity; and by the intimacy between everyday life and that which destroys it. This transcendence will be general, undivided and built by subjectivity (1). Once they abandon their initial extremism, revolutionary elements become irremediably reformist. The well-nigh general abandonment of the revolutionary spirit in our time is a soil in which reformisms of survival thrive. Any modern revolutionary organization must identify the seeds of transcendence in the great movements of the past. In particular, it must rediscover and carry through the project of individual freedom, perverted by liberalism; the project of collective freedom, perverted by socialism; the project of the recapture of nature, perverted by fascism; and the project of the whole person, perverted by Marxist ideologies. This last project, though expressed in the theological terms of the time, also informed the great medieval heresies and their anticlerical rage, the recent exhumation of which is so apt in our own century with its new clergy of "experts" (2). People of ressentiment are the perfect survivors people bereft of the consciousness of possible transcendence, people of the age of decomposition (3). By becoming aware of spectacular decomposition, a person of ressentiment becomes a nihilist. Active nihilism is prerevolutionary. There is no consciousness of transcendence without consciousness of decomposition. Juvenile delinquents are the legitimate heirs of Dada (4).

\section{The Question of Transcendence}

Refusal is multiform; transcendence is one. Faced by modern discontent and incited by it to bear witness, human history is quite simply the history of a radical refusal which invariably carries transcendence within itself, which invariably tends towards self-negation. Although only one or two aspects of this refusal are ever seen at a time, this can never successfully conceal the basic identity of dictatorship by God, monarch, chief, class or organization. What idiocy it is to evoke an ontology of revolt. By transforming natural alienation into social alienation, the movement of history teaches us freedom in servitude: it teaches us both revolt and submission. Revolt has less need of metaphysicians than metaphysicians have of revolt. Hierarchical power, which has been with us for millennia, furnishes a perfectly adequate explanation for the permanence of rebellion, as it does of the repression that smashes rebellion.

The overthrow of feudalism and the creation of masters without slaves are one and the same project. The memory of the partial failure of this project in the French Revolution has continued to render it more familiar and more attractive, even as later revolutions, each in their own way abortive (the Paris Commune, the Bolshevik Revolution), have at once clarified the project's contours and deferred its enactment.

All philosophies of history without exception collude with this failure, which is why consciousness of history cannot be divorced from consciousness of the necessity of transcendence. 
How is it that the moment of transcendence is increasingly easy to discern on the social horizon? The question of transcendence is a tactical question. Broadly, we may outline it as follows:

1.

a. Anything that does not kill power reinforces it, but anything which power does not itself kill weakens power.

b. The more the requirements of consumption come to supersede the requirements of production, the more government by constraint gives way to government by seduction.

c. With the democratic extension of the right to consume comes a corresponding extension to the largest group of people of the right to exercise authority (in varying degrees, of course).

d. As soon as people fall under the spell of Authority they are weakened and their capacity for refusal withers. Power is thus reinforced, it is true, yet it is also reduced to the level of the consumable and is indeed consumed, dissipated and, of necessity, becomes vulnerable.

The point of transcendence is one moment in this dialectic of strength and weakness. While it is undoubtedly the task of radical criticism to identify this moment and to work tactically to precipitate it, we must not forget that it is the facts all around us that call such radical criticism forth. Transcendence sits astride a contradiction that haunts the modern world, permeating the daily news and leaving its stamp on most of our behaviour. This is the contradiction between impotent refusal i.e., reformism and wild refusal, or nihilism (two types of which, the active and the passive, are to be distinguished).

1. The diffusion of hierarchical power may broaden that power's realm but it also tarnishes its glamour. Fewer people live on the fringes of society as bums and parasites, yet at the same time fewer people actually respect an employer, a monarch, a leader or a role; although more people survive within the social organization, many more of the people within it hold it in contempt. Everyone finds themself at the center of the struggle in their daily life. This has two consequences:

a. In the first place, the individual is not only the victim of social atomization, he or she is also the victim of fragmented power. Now that subjectivity has emerged onto the historical stage, only to come immediately under attack, it has become the most crucial revolutionary demand. Henceforward the construction of a harmonious collectivity will require a revolutionary theory founded not on communitarianism but rather upon subjectivity a theory founded, in other words, on individual cases, on the lived experience of individuals.

b. Secondly, the extreme fragmentariness of resistance and refusal turns, ironically, into its opposite, for it recreates the preconditions for a global refusal. The new revolutionary collective will come into being through a chain reaction leaping from one subjectivity to the next. The construction of a community of people who are whole individuals will inaugurate the reversal of perspective without which no transcendence is possible. 
2. A final point is that the idea of a reversal of perspective is invading popular consciousness. For everyone is too close for comfort to that which negates them. This proximity to death makes the life forces rebel. Just as the allure of faraway places fades when one gets closer, so perspective vanishes as the eye gets too near. By locking people up in its decor of things, and by its clumsy attempt to insinuate itself into people themselves, all Power manages to do is to spread the discontent and disaffection. Vision and thought get muddled, values blur, forms become vague, and anamorphic distortions trouble us rather as though we were looking at a painting with our nose pressed hard against the canvas. Incidentally, the change in pictorial perspective (Uccello, Kandinsky) coincided with a change of perspective at the level of social life. The rhythm of consumption thrusts the mind into that interregnum where far and near are indistinguishable. The facts themselves will soon come to the aid of the mass of humanity in their struggle to enter at long last that state of freedom aspired to though they lacked the means of attaining it by those Swabian heretics of 1270 mentioned by Norman Cohn in his Pursuit of the Millennium, who "said that they had mounted up above God and, reaching the very pinnacle of Divinity, abandoned God. Often the adept would affirm that he or she had no longer 'any need of God."

\section{The Renunciation of Poverty and the Poverty of Renunciation}

Almost every revolutionary movement embodies the desire for complete change, yet up to now almost every revolutionary movement has succeeded only in changing some detail. As soon as the people in arms renounces its own will and starts kow-towing to the will of its counsellors it loses control of its freedom and confers the ambiguous title of revolutionary leader upon its oppressors-to-be. This is the "cunning", so to speak, of fragmentary power: it gives rise to fragmentary revolutions, revolutions dissociated from any reversal of perspective, cut off from the totality, paradoxically detached from the proletariat which makes them. There is no mystery in the fact that a totalitarian regime is the price paid when the demand for total freedom is renounced once a handful of partial freedoms has been won. How could it be otherwise! People talk in this connection of a fatality, a curse: the revolution devouring its children, and so on. As though Makhno's defeat, the crushing of Kronstadt revolt, or Durruti's assassination were not already writ large in the structure of the original Bolshevik cells, perhaps even in Marx's authoritarian positions in the First International. "Historical necessity" and "reasons of state" are simply the necessity and the reasons of leaders who have to legitimate their renunciation of the revolutionary project, their renunciation of extremism.

Renunciation equals non-transcendence. And issue-politics, partial refusal and piecemeal demands are the very thing that blocks transcendence. The worst inhumanity is never anything but a wish for emancipation that has settled for compromise and fossilized beneath the strata of successive sacrifices. Liberalism, socialism and Bolshevism have each built new prisons under the sign of liberty. The left fights for an increase in comfort within alienation, skillfully furthering this impoverished aim by evoking the barricades, the red flag and the finest revolutionary moments of the past. In this way once-radical impulses are doubly betrayed, twice renounced: first they are ossified, then dug up and used as a carrot. "Revolution" is doing pretty well everywhere: worker-priests, priest-junkies, communist generals, red potentates, trade unionists on the board of directors... Radical chic harmonizes perfectly with a society that can sell Watney's Red 
Barrel beer under the slogan "The Red Revolution is Coming." Not that all this is without risk for the system. The endless caricaturing of the most deeply felt revolutionary desires can produce a backlash in the shape of a resurgence of such feelings, purified in reaction to their universal prostitution. There is no such thing as lost allusions.

The new wave of insurrection tends to rally young people who have remained outside specialized politics, whether right or left, or who have passed briefly through these spheres because of excusable errors of judgement, or ignorance. All currents merge in the tide race of nihilism. The only important thing is what lies beyond this confusion. The revolution of daily life will be the work of those who, with varying degrees of facility, are able to recognize the seeds of total selfrealization preserved, contradicted and dissimulated within ideologies of every kind and who cease consequently to be either mystified or mystifiers.

If a spirit of revolt once existed within Christianity, I defy anybody who still calls himself a Christian to understand that spirit. Such people have neither the right nor the capacity to inherit the heretical tradition. Today heresy is an impossibility. The theological language used to express the impulses of so many fine revolts was the mark of a particular period; it was the only language then available, and nothing more than that. Translation is now necessary not that it presents any difficulties. Setting aside the period in which I live, and the objective assistance it gives me, how can I hope to improve in the twentieth century on what the Brethren of the Free Spirit said in the thirteenth: "A man may be so much one with God that whatever he does he cannot sin. I am part of the freedom of Nature and I satisfy all my natural desires. The free man is perfectly right to do whatever gives him pleasure. Better that the whole world be destroyed and perish utterly than that a free man should abstain from a single act to which his nature moves him." One cannot but admire Johann Hartmann's "The truly free man is lord and master of all creatures. All things belong to him, and he is entitled to make use of whichever pleases him. If someone tries to stop him doing so, the free man has the right to kill him and take his possessions." The same goes for John of Brunn, who justifies his practice of fraud, plunder and armed robbery by announcing that "All things created by God are common property. Whatever the eye sees and covets, let the hand grasp it." Or again, consider the Pifles d'Arnold and their conviction that they were so pure that they were incapable of sinning no matter what they did (1157). Such jewels of the Christian spirit always sparkled a little too brightly for the bleary eyes of the Christians. The great heretical tradition may still be discerned dimly perhaps, but with its dignity still intact in the acts of a Pauwels leaving a bomb in the church of La Madeleine (March 15, 1894), or of the young Robert Burger slitting a priest's throat (August 11, 1963). The last and the last possible instances of priests retrieving something genuine from a real attachment to the revolutionary origins of Christianity are furnished in my opinion by Meslier and Jacques Roux fomenting jacquerie and riot. Not that we can expect this to be understood by the sectarians of today's ecumenizing forces. These emanate from Moscow as readily as from Rome, and their evangelists are cybernetician scum as often as creatures of Opus Dei. Such being the new clergy, the way to transcend heresy should not be hard to divine. 
No one is about to deny liberalism full credit for having spread the thirst for freedom to every corner of the world. Freedom of the press, freedom of thought, freedom of creation if all their "freedoms" have no other merit, at least they stand as a monument to liberalism's falseness. The most eloquent of epitaphs, in fact: after all, it is no mean feat to imprison liberty in the name of liberty. In the liberal system, the freedom of individuals is destroyed by mutual interference: one person's liberty begins where the other's ends. Those who reject this basic principle are destroyed by the sword; those who accept it are destroyed by justice. Nobody gets their hands dirty: a button is pressed, and the guillotine of the police and state intervention falls. A very fortunate business, to be sure. The State is the bad conscience of the liberal, the instrument of a necessary repression for which deep in their heart they deny responsibility. As for day-to-day business, it is left to the freedom of the capitalists to keep the freedom of the worker within proper bounds. Here, however, the upstanding socialist comes on the scene to denounce this hypocrisy.

What is socialism? It is a way of getting liberalism out of its contradiction, i.e., the fact that it simultaneously safeguards and destroys individual freedom. Socialism proposes (and there could be no more worthy goal) to prevent individuals from negating each other through interference. The solution it actually produces, however, is very different. For it ends up eliminating interferences without liberating the individual; what is much worse, it melds the individual will into a collective mediocrity. Admittedly, only the economic sphere is affected by the institution of socialism, and opportunism i.e., liberalism in the sphere of daily life is scarcely incompatible with bureaucratic planning of all activities from above, with manoeuvering for promotion, with power struggles between leaders, etc. Thus socialism, by abolishing economic competition and free enterprise, puts an end to interference on one level, but it retains the race for the consumption of power as the only authorized form of freedom. The partisans of self-limiting freedom are split into two camps, therefore: those who are for liberalism in production and those who are for liberalism in consumption. And a fat lot of difference there is between them!

The contradiction in socialism between radicalism and its renunciation is well exemplified by two statements recorded in the minutes of the debates of the First International. In 1867 we find Chémalé reminding his listeners that "The product must be exchanged for another product of equal value; anything less amounts to trickery, to fraud, to robbery." According to Chémalé, therefore, the problem is how to rationalize exchange, how to make it fair. The task of socialism, on this view, is to correct capitalism, to give it a human face, to plan it, and to empty it of its substance (profit). And who profits from the end of capitalism? This we have found out since 1867. But there was already another view of socialism, coexistent with this one, and we find it expressed by Varlin, Communard-to-be, at the Geneva Congress of this same International Association of Workingmen in 1866: "So long as anything stands in the way of the employment of oneself freedom will not exist." There is thus a freedom locked up in socialism, but nothing could be more foolhardy than to try and release this freedom today without declaring total war on socialism itself.

Is there any need to expatiate on the abandonment of the Marxist project by every variety of present-day Marxism? The Soviet Union, China, Cuba: what is there here of the construction of the whole man? The material poverty which fed the revolutionary desire for transcendence and radical change has been attenuated, but a new poverty has emerged, a poverty born of renunciation and compromise. The renunciation of poverty has led only to the poverty of renunciation. Was it not the feeling that he had allowed his initial project to be fragmented and effected in piecemeal fashion that occasioned Marx's disgusted remark, "I am not a Marxist"? Even the ob- 
scenity of fascism springs from a will to live but a will to live denied, turned against itself like an ingrowing toenail. A will to live become a will to power, a will to power become a will to passive obedience, a will to passive obedience become a death wish. For when it comes to the qualitative sphere, to concede a fraction is to give up everything.

By all means, let us destroy fascism, but let the same destructive flame consume all ideologies, and all their lackeys to boot.

Through force of circumstance, poetic energy is everywhere renounced or allowed to go to seed. Isolated people abandon their individual will, their subjectivity, in an attempt to break out. Their reward is the illusion of community and an intenser affection for death. Renunciation is the first step towards a man's co-optation by the mechanisms of Power.

There is no such thing as a technique or thought which does not arise in the first instance from a will to live; in the official world, however, there is no such thing as a technique or thought which does not lead us towards death. The faces of past renunciations are the data of a history still largely unknown to us. The study of these traces helps in itself to forge the arms of total transcendence. Where is the radical core, the qualitative dimension? This question has the power to shatter habits of mind and habits of life; and it has a part to play in the strategy of transcendence, in the building of new networks of radical resistance. It may be applied to philosophy, where ontology bears witness to the renunciation of being-as-becoming. It may be applied to psychoanalysis, a technique of liberation which confines itself for the most part to "liberating" us from the need to attack social organization. It may be applied to all the dreams and desires stolen, violated and twisted beyond recognition by conditioning. To the basically radical nature of our spontaneous acts, so often denied by our stated view of ourselves and of the world. To the playful impulse, whose present imprisonment in the categories of permitted games from roulette to war, by way of lynching parties leaves no place for the authentic game of playing with each moment of daily life. And to love, so inseparable from revolution, and so largely cut off, as things stand, from the pleasure of giving.

Remove the qualitative and all that remains is despair. Despair comes in every variety available to a system designed for killing human beings, the system of hierarchical power: reformism, fascism, philistine politicism, mediocracy, activism and passivity, boyscoutism and ideological masturbation. A friend of Joyce's recalls: "l don't remember Joyce ever saying a word during all those years about Poincaré, Roosevelt, de Valera, Stalin; never so much as a mention of Geneva or Locarno, Abyssinia, Spain, China, Japan, the Prince affair, Violette Nozière..." What, indeed, could he have added to Ulysses and Finnegan's Wake? Once the Capital of individual creativity had been written, it only remained for the Leopold Blooms of the world to unite, to throw off their miserable survival and to actualize the richness and diversity of their "interior monologues" in the lived reality of their existence. Joyce was never a comrade-in-arms to Durruti; he fought shoulder to shoulder with neither the Asturians nor the Viennese workers. But he had the decency to pass no comment on news items, to the anonymity of which he abandoned Ulysses that "monument of culture," as one critic put it while at the same time abandoning himself, Joyce, the man of total subjectivity. To the spinelessness of the man of letters, Ulysses is witness. As to the spinelessness of renunciation, its witness is invariably the "forgotten" radical moment.

Thus revolutions and counterrevolutions follow hard upon one another's heels, sometimes within a twenty-four hour period in the space, even, of the least eventful of days. But conscious- 
ness of the radical act and of its renunciation becomes more widespread and more discriminating all the time. Inevitably. For today survival is non-transcendence become unliveable.

\section{The Individual of Ressentiment}

The more power is dispensed in consumer size packs, the more circumscribed becomes the sphere of survival, until we enter that reptilian world in which pleasure, the effort of liberation and agony all find expression in a single shudder. Low thought and short sight have long signalled the fact that the bourgeoisie belongs to a civilization of troglodytes in the making, a civilization of survival perfectly epitomized by the invention of the fallout shelter complete with all modern conveniences. The greatness of the bourgeoisie is a borrowed cloak: unable to build truly on the back of its defeated opponent, it donned feudal robes only to find itself draped in a pale shadow of feudal virtue, of God, of nature, etc. No sooner had it discovered its incapacity to control these entities directly than it fell to internal squabbling over details, involuntarily dealing itself blow after blow though never, it is true, a mortal one.

The same Flaubert who flays the bourgeois with ridicule calls them to arms to put down the Paris Commune...

The nobility turns the bourgeois into an aggressor: the proletariat puts it on the defensive. What does the proletariat represent for the bourgeoisie? Not a true adversary: at the most a guilty conscience that it desperately tries to conceal. Withdrawn, seeking a position of minimum exposure to attack, proclaiming that reform is the only legitimate form of change, the bourgeoisie clothes its fragmented revolutions in a cloth of wary envy and resentment.

I have already said that in my view no insurrection is ever fragmentary in its initial impulses, that it only becomes so when the poetry of agitators and ringleaders gives way to authoritarian leadership. The individual of ressentiment is the official world's travesty of a revolutionary: an individual bereft of awareness of the possibility of transcendence; a person who cannot grasp the necessity for a reversal of perspective and who, gnawed by envy, spite and despair, tries to use these feelings as weapons against a world so well designed for his or her oppression. An isolated person. A reformist pinioned between total refusal and absolute acceptance of Power. They reject hierarchy out of umbrage at not having a place therein, and this makes them, as rebels, ideal slaves to the designs of revolutionary "leaders". Power has no better buttress than thwarted ambition, which is why it makes every effort to console losers in the rat race by flinging them the privileged as a target for their rancour.

Short of a reversal in perspective, therefore, hatred of power is merely another form of obeisance to Power's ascendancy. The person who walks under a ladder to prove their freedom from superstition proves just the opposite. Obsessive hatred and the insatiable thirst for positions of authority wear down and impoverish people to the same degree though perhaps not in the same way, for there is, after all, more humanity in fighting against Power than in prostituting oneself to it. There is in fact a world of difference between struggling to live and struggling not to die. Revolts within the realm of survival are measured by the yardstick of death, which explains why they always require self-abnegation on the part of their militants, and the a priori renunciation of that will to live for which everyone is in reality struggling.

The rebel with no other horizon than a wall of restraints either rams their head against this wall or ends up defending it with dogged stupidity. No matter whether one accepts or rejects 
Power, to see oneself in the light of constraints is to see things from Power's point of view. Here we have humanity at the vanishing point swarming with vermin, in Rosanov's words. Hemmed in on all sides, they resist any kind of intrusion and mount a jealous guard over themselves, never realizing that they have become sterile, that they are keeping vigil over a graveyard. They have internalized their own lack of existence. Worse, they borrow Power's impotence in order to fight Power; such is the zeal with which they apply the principle of fair play. Alongside such sacrifice, the price they pay for purity for playing at being pure is small indeed. How the most compromised people love to give themselves credit for integrity out of all proportion to the odd minor points over which they have preserved any! They get on their high horses because they refused a promotion in the army, gave out a few leaflets at a factory gate or got hit on the head by a cop. And all their bragging goes hand in hand with the most obtuse militantism in some communist party or other.

Once in a while, too, an individual at the vanishing point takes it into their head that they have a world to conquer, that they need more Lebensraum, a vaster ruin in which to engulf themself. The rejection of Power easily comes to embrace the rejection of those things which Power has appropriated e.g., the rebel's own self. Defining oneself negatively by reference to Power's constraints and lies can result in constraints and lies entering the mind as an element of travestied revolt generally without so much as a dash of irony to give a breath of air. No chain is harder to break than the one which the individual attaches to themself when their rebelliousness is lost to them in this way. When they place their freedom in the service of unfreedom, the resulting increase in unfreedom's strength enslaves them. Now, it may well be that nothing resembles unfreedom so much as the effort to attain freedom, but unfreedom has this distinguishing mark: once bought, it loses all its value. even though its price is every bit as high as freedom's.

The wails close in and we can't breath. The more people struggle for breath, the worse it gets. The ambiguity of the signs of life and freedom, which oscillate between their positive and negative forms according to the necessary conditions imposed by global oppression, tends to generalize a confusion in which one hand is constantly undoing the work of the other. Inability to apprehend oneself encourages people to apprehend others on the basis of their negative representations, on the basis of their roles and thus to treat them as objects. Old bachelors, bureaucrats all, in fact, who thrive on survival have no affective knowledge of any other reason for existing. Needless to say, Power's best hopes of co-optation lie precisely in this shared malaise. And the greater the mental confusion, the greater its chances.

Myopia and voyeurism are the twin prerequisites of humanity's adaptation to the social mediocrity of the age. Look at the world through a keyhole! This is what all the experts urge us to do, and what the individual of ressentiment delights in doing. Unable to play a leading part, they rush to get the best seat in the auditorium. They are desperately in need of minute platitudes to chew on: all politicians are crooks, de Gaulle is a great man, China is a workers' paradise, etc. They love to hate an individualized oppressor, to love a flesh-and-blood Uncle Joe: systems are too complicated for them. How easy it is to understand the success of such crass images as the foul Jew, the shiftless native or the two hundred families! Give the enemy a face and immediately the countenance of the masses apes another most admirable face, the face of the Defender of the Fatherland, Ruler, Fuhrer.

The individual of ressentiment is a potential revolutionary, but the development of this potentiality entails passing through a phase of larval consciousness: to first become a nihilist. If they do not kill the organizers of their ennui, or at least those people who appear as such in 
the forefront of their vision (managers, experts, ideologues, etc.), then they will end up killing in the name of an authority, in the name of some reason of state, or in the name of ideological consumption. And if the state of things does not eventually provoke a violent explosion, they will continue to flounder in a sea of roles, locked in the tedious rigidity of their spite, spreading their saw-toothed conformism everywhere and applauding revolt and repression alike; for, in this eventuality, incurable confusion is their only possible fate.

\section{The Nihilist}

The nihilist. Rozanov's definition of nihilism is the best: "The show is over. The audience get up to leave their seats. Time to collect their coats and go home. They turn round...No more coats and no more home."

Nihilism is born of the collapse of myth. During those periods when the contradiction between mythical explanation Heaven, Redemption, the Will of Allah and everyday life becomes patent, all values are sucked into the vortex and destroyed. Deprived of any justification, stripped of the illusions that concealed it, the weakness of humanity emerges in all its nakedness. On the other hand, once myth no longer justifies the ways of Power to us, the real possibilities of social action and experiment appear. Myth was not just a cloak for this weakness: it was also the cause of it. Thus the explosion of myth frees an energy and creativity too long syphoned away from authentic experience into religious transcendence and abstraction. The interregnum between the collapse of classical philosophy and the erection of the Christian myth saw an unprecedented effervescence of thought and action. A thousand life-styles blossomed. Then came the dead hand of Rome, co-opting whatever it could not destroy utterly. Later, in the sixteenth century, the Christian myth itself disintegrated, and another period of frenetic experimentation burst upon the world. Nothing was true anymore, and everything had become possible. Gilles de Rais tortured a thousand children to death, and the revolutionary peasants of 1535 set about building heaven on earth. But this new period of dissolution differed in one important respect from all previous ones, for after 1789 the reconstruction of a new myth became an absolute impossibility.

Christianity neutered the explosive nihilism of certain gnostic sects, and improvised a protective garment for itself from their remains. But the establishment of the bourgeois world made any new displacement of nihilistic energy on to the plane of myth impossible: the nihilism generated by the bourgeois revolution was a concrete nihilism. The reality of exchange, as we have seen, precludes all dissimulation. Until its abolition, the spectacle can never be anything except the spectacle of nihilism. That vanity of the world which the Pascal of the Pensées evoked, as he thought, to the greater glory of God, turned out to be a product of historical reality and this in the absence of God, himself a casualty of the explosion of myth. Nihilism swept everything before it, God included.

For the last century and a half, the most lucid contributions to art and life have been the fruit of free experiment in the field of abolished values. De Sade's passionate rationalism, Kierkegaard's sarcasm, Nietszche's vacillating irony, Maldoror's violence, Mallarmé's icy dispassion, Jarry's Umour, Dada's negativism these are the forces which have reached out to confront people with some of the dankness and acridity of decaying values. And also, with the desire for a reversal of perspective, the need to discover alternative forms of life the area which Melville called, "that wild whaling life where individual notabilities make up all totalities." Paradox: 
a. The great propagators of nihilism lacked an essential weapon: the sense of historic reality, the sense of the reality of decay, erosion, fragmentation.

b. Those who have made history in the period of bourgeois decline have been tragically lacking in any acute awareness of the immense dissolvent power of history in this period. Marx failed to analyze Romanticism and the artistic phenomenon in general. Lenin was wilfully blind to the importance of everyday life and its degeneration, of the Futurists, of Mayakovsky, or of the Dadaists.

Nihilism and historical consciousness have yet to join forces: Marx smashing something better than the street lamps in Kentish Town; Mallarmé with fire in his belly. The gap between these two forces is an open door to the hordes of passive liquidators, nihilists of the official world doggedly destroying the already dead values they pretend to believe in. How long must we bear the hegemony of these communist bureaucrats, fascist brutes, opinion makers, pockmarked politicians, sub-Joycean writers, neo-Dadaist thinkers all preaching the fragmentary, all working assiduously for the Big Sleep and justifying themselves in the name of one Order or another: the family, morality, culture, the flag, the space race, margarine, etc. Perhaps nihilism could not have attained the status of platitude if history had not advanced so far. But advanced it has. Nihilism is a self-destruct mechanism: today a flame, tomorrow ashes. The old values in ruins today feed the intensive production of consumable and "futurized" values sold under the old label of "the modern"; but they also thrust us inevitably towards a future yet to be constructed, towards the transcendence of nihilism. In the consciousness of the new generation a slow reconciliation is occurring between history's destructive and constructive tendencies. The alliance of nihilism and transcendence means that transcendence will be total. Here lies the only wealth to be found in the affluent society.

When the individual of ressentiment becomes aware of the dead loss which is survival, they turn into a nihilist. They embrace the impossibility of living so tightly that even survival becomes impossible. Once you are in that void, everything breaks up. The horrors. Past and future explode; the present is ground zero. And from ground zero there are only two ways out, two kinds of nihilism: active and passive.

The passive nihilist compromises with his own lucidity about the collapse of all values. They make one final nihilistic gesture: throw a dice to decide their "cause", and become its devoted slave, for Art's sake, and for the sake of a little bread... Nothing is true, so a few gestures become hip. Joe Soap intellectuals, pataphysicians, crypto-fascists, aesthetes of the acte gratuit, mercenaries, Kim Philbys, pop-artists, psychedelic impresarios bandwagon after bandwagon works out its own version of the credo quia absurdum est: you don't believe in it, but you do it anyway; you get used to it and you even get to like it in the end. Passive nihilism is an overture to conformism.

After all, nihilism can never be more than a transition, a shifting, ill-defined sphere, a period of wavering between two extremes, one leading to submission and subservience, the other to permanent revolt. Between the two poles stretches a no-man's-land, the wasteland of the suicide and the solitary killer, of the criminal described so aptly by Bettina as the crime of the State. Jack the Ripper is essentially inaccessible. The mechanisms of hierarchical power cannot touch him; he cannot be touched by revolutionary will. He gravitates round that zero-point beyond which 
destruction, instead of reinforcing the destruction wrought by power, beats it at its own game, excites it to such violence that the machine of the Penal Colony, stabbing wildly, shatters into pieces and flies apart. Maldoror takes the disintegration of contemporary social organization to its logical conclusion: to the stage of its self-destruction. The individual's absolute rejection of society as a response to society's absolute rejection of the individual. Isn't this the still point of the reversal of perspective, the exact point where movement, dialectics and time no longer exist? Noon and eternity of the great refusal. Before it, the pogroms; beyond it, the new innocence. The blood of Jews or the blood of cops.

The active nihilist does not simply watch things fall apart. He criticizes the causes of disintegration by speeding up the process. Sabotage is a natural response to the chaos ruling the world. Active nihilism is pre-revolutionary; passive nihilism is counter revolutionary. And most people waltz tragicomically between the two. Like the red soldier described by some Soviet author Victor Chlovsky perhaps who never charged without shouting, "Long Live the Tsar!" But circumstances inevitably end by drawing a line, and people suddenly find themselves, once and for all, on one side or the other of the barricades.

You learn to dance for yourself on the off-beat of the official world. And you must follow your demands to their logical conclusion, not accept a compromise at the first setback. Consumer society's frantic need to manufacture new needs adroitly cashes in on the way-out, the bizarre and the shocking. Black humour and real agony turn up on Madison Avenue. Flirtation with nonconformism is an integral part of prevailing values. Awareness of the decay of values has its role to play in sales strategy. More and more pure rubbish is marketed. The figurine salt-shaker of Kennedy, complete with "bullet-holes" through which to pour salt, for sale in the supermarket, should be enough to convince anybody, if there is anybody who still needs convincing, how easily a joke which once would have delighted Ravachol or Peter the Painter now merely helps to keep the market going.

Consciousness of decay reached its most explosive expression in Dada. Dada really did contain the seeds by which nihilism could have been surpassed; but it just left them to rot, along with all the rest. The whole ambiguity of surrealism, on the other hand, lies in the fact that it was an accurate critique made at the wrong moment. While its critique of the transcendence aborted by Dada was perfectly justified, when it in its turn tried to surpass Dada it did so without going back to Dada's initial nihilism, without basing itself on Dada-anti-Dada, without seeing Dada historically. History was the nightmare from which the surrealists never awoke: they were defenseless before the Communist Party, they were out of their depth with the Spanish Civil War. For all their yapping they slunk after the official left like faithful dogs.

Certain features of Romanticism had already proved, without awakening the slightest interest on the part of either Marx or Engels, that art the pulse of culture and society is the first index of the decay and disintegration of values. A century later, while Lenin thought that the whole issue was beside the point, the Dadaist could see the artistic abscess as a symptom of a cancer whose poison was spread throughout society. Unpleasant art only reflects the repression of pleasure instituted by Power. It is this the Dadaists of 1916 proved so cogently. To go beyond this analysis could mean only one thing: to take up arms. The neo-Dadaist larvae pullulating in the shitheap of present-day consumption have found more profitable employment. 
The Dadaists, working to cure themselves and their civilization of their discontents working, in the last analysis, more coherently than Freud himself built the first laboratory for the revitalization of everyday life. Their activity was far more radical than their theory. Grosz: "The point was to work completely in the dark. We didn't know where we were going." The Dada group was a funnel sucking in all the trivia and garbage cluttering up the world. Reappearing at the other end, everything was transformed, original, brand new. Though people and things stayed the same they took on totally new meanings. The reversal of perspective was begun in the magic of rediscovering lost experience. Subversion, the tactics of the reversal of perspective, overthrew the rigid frame of the old world. This upheaval showed exactly what is meant by "poetry made by everyone" a far cry indeed from the literary mentality to which the surrealists eventually succumbed.

The initial weakness of Dada lay in its extraordinary humility. Think of Tzara, who, it is said, used every morning to repeat Descartes' statement, "l don't even want to know whether there were men before me." In this Tzara, a buffoon taking himself as seriously as a pope, it is not hard to recognize the same individual who would later spit on the memory of such men as Ravachol, Bonnot and Makhno's peasant army by joining up with the Stalinist herds.

If Dada broke up because transcendence was impossible, the blame still lies on the Dadaists themselves for having failed to search the past for the real occasions when such transcendence became a possibility: those moments when the masses arise and take their destiny into their own hands.

The first compromise is always terrible in its effects. Dada's original error tainted its heirs irrevocably: it infected surrealism throughout its history, and finally turned malignant witness neo-Dadaism. Admittedly, the surrealists looked to the past. But with what results? While they were right in recognizing the subversive genius of a Sade, a Fourier or a Lautréamont, all they could do then was to write so much and so well about them as to win for their heroes the honour of a few timid footnotes in progressive school textbooks. A literary celebrity much like the celebrity the Neo-Dadaists win for their forebears in the present spectacle of decomposition.

The only modern phenomena comparable to Dada are the most savage outbreaks of juvenile delinquency. The same contempt for art and bourgeois values. The same refusal of ideology. The same will to live. The same ignorance of history. The same barbaric revolt. The same lack of tactics.

The nihilist makes one mistake: they do not realize that other people are also nihilists, and that the nihilism of other people is now an active historical factor. They have no consciousness of the possibility of transcendence. The fact is, however, that the present reign of survival, in which all the talk about progress expresses nothing so much as the fear that progress may be impossible, is the outcome of a series of past revolutionary defeats. The history of survival is the historical movement which will eventually turn these defeats into harbingers of victory.

Awareness of just how nightmarish life has become is on the point of fusing with a rediscovery of the real revolutionary movement in the past. We must reappropriate the most radical aspects of all past revolts and insurrections at the point where they were prematurely arrested, and bring to this task all the violence bottled up inside us. A chain explosion of subterranean creativity cannot fail to overturn the world of hierarchical power. In the last reckoning, the nihilists are 
our only allies. They cannot possibly go on living as they are. Their lives are like an open wound. A revolutionary perspective could put all the latent energy generated by years of repression at the service of their will to live. Anyone who combines consciousness of past renunciations with a historical consciousness of decomposition is ready to take up arms in the cause of the transformation of daily life and of the world. Nihilists, as de Sade would have said, one more effort if you want to be revolutionaries! 


\section{Part II. The Reversal of Perspective}




\section{Chapter 19. The Reversal of Perspective}

The light of power is waning. The eyes of individual subjectivity cannot adapt to mere holes in a mask, which are the eyes of those fog-bound in shared illusion. The individual's point of view must prevail over false collective participation. In total self-possession, reach society with the tentacles of subjectivity and remake everything startingwith yourself. The reversal of perspsctive is what is positive in negativity, the fruit which will burst out of the old world's bud (1-2).

One day Monsieur Keuner was asked just what was meant by "reversal of perspective"; and he told the following story. Two brothers deeply attached to one another had a strange habit. They marked the nature of the day's events with pebbles a white one for each happy moment and a black one for each moment of misfortune or displeasure. But when, at the end of the day, they compared the contents of the jars one found only white pebbles and the other only black.

Fascinated by the persistence with which they lived the same experience differently, they both agreed to ask the advice of an old man famed for his wisdom. "You don't talk to one another enough" said the wise man, "Both of you must give the reasons for your choice, and discover its causes". From then on they did so, and soon discovered that while the first remained faithful to his white pebbles and the second to his black ones, in neither jar were there as many pebbles as before. Where there had been about thirty there were hardly more than seven or eight. After a short while they went to see the wise man again. Both looked extremely miserable. "Not so long ago," said one, "my jar was filled with pebbles the colour of the night. My despair was unbroken; I continued to live, I admit, only through the force of habit. Now I hardly ever collect more than eight pebbles, but what these eight signs of misery represent has become so intolerable that I cannot go on like this." And the other said: "Every day I piled up white pebbles.. Today there are only seven or eight, but these obsess me to the point that I cannot recall these moments of happiness without immediately wanting to relive them more intensely and, in a word, eternally. This desire torments me". The wise man smiled as he listened to them. "Excellent. Things are shaping up well. Keep at it. And one thing: whenever you can, ask yourselves why the game with the jar and the pebbles arouses so much passion in you." When the two brothers next saw the wise man it was to say "We asked ourselves the question but we could not find the answer. So we asked the whole village. You can see how much it has disturbed them. In the evening. squatting in front of their houses, whole families discuss the black and white pebbles. Only the elders and chieftains refuse to take part. They say a pebble is a pebble, and all are of equal value." The old man didn't conceal his pleasure. "Everything is developing as I foresaw. Don't worry. Soon the question will no longer be asked: it has lost its importance, and perhaps one day you will no longer believe you ever asked it." Shortly afterwards the old man's predictions were confirmed in the following way: a great joy overcame the members of the village; at the dawn of a troubled night, the rays of the sun fell upon the heads of the elders and chieftains, impaled upon the sharp-pointed stakes of the palisade.

The world has always had a geometry. The angle and perspective within which men could see, speak to, and represent each other was at first decided solely by the gods of the unitary 
epochs. Then men, the men of the bourgeoisie, played a fast one on them: they placed them in perspective, arraying them in an historical becoming in which they were born, developed and killed off. History was the twilight of the gods.

Seen historically, God is confused with the dialectlc of his material aspect, masters and slaves, the history of class struggle and hierarchical social power. Thus in a sense the bourgeoisie began the reversal of perspective, only immediately to limit it to appearance. God may be abolished, but the pillars which held him up still rise towards the empty sky. And, as if the explosion in the cathedral of sacred values spread in very slow shock waves, the crumbling of mythic rubble is only complete today in the disintegration of the spectacle, nearly two centuries after the attack. The bourgeoisie is only a stage in the dynamiting of God who is now about to disappear once and for all and with him all trace of his material origin: man's domination of man.

Economic mechanisms, whose control and strength the bourgeoisie partially possessed, revealed the materiality of power, releasing it from the divine phantom. But at what price? God offered a sort of refuge in his vast negation of the human in which the faithful paradoxically had licence to affirm themselves against temporal authority by opposing the absolute power of God to the 'usurped' power of priests and rulers, as the mystics so often did. Today it is power which sidles up to men and solicits them to consume it. It weighs more and more heavily, reducing the space of life to mere survival, compressing time to the density of a "role". To use a facile image, one could compare power to an angle. Acute at first, its summit lost in the depths of the sky, then gradually growing wider as its summit sinks, becomes visible and subsides to the point of becoming flat, extending its sides in a straight line, which cannot be distinguished from a succession of points, equivalent and without strength.

Beyond this line, which is that of nihilism, a new perspective opens, which is neither the reflection of the previous one nor its involution. On the contrary, it is a body of individual perspectives in harmony, never entering into conflict, but constructing the world according to the principles of coherence and collectivity. All these angles, all different, nevertheless open in the same direction, individual will henceforward being indistinguishable from collective will.

The function of conditioning is to place and displace everyone along the length of the hierarchical ladder. The reversal of perspective entails a sort of anti-conditioning, not conditioning of a new type, but playful tactics:diversion.

The reversal of perspective replaces knowledge by praxis, hope by freedom and mediation by the will of the here and now. It consecrates the triumph of a body of human relationships founded on three inseparable poles: participation, communication and realization.

To reverse perspective is to stop seeing with the eyes of the community, ideology. family or other people. It is to grasp oneself firmly, to choose oneself as starting point and centre. To base everything on subjectivity and to follow one's subjective will to be everything. In the sights of my insatiable desire to live, the whole of power is only one particular target within a wider horizon. It's show of strength doesn't obstruct my vision, but I locate it, estimate its dangers, and study its movement. My creativity, however poor it may be, is a more certain guide than all the knowledge I have been forced to acquire. In the night of power, its glow holds the hostile forces at bay: cultural conditioning, every type of specialisation and Weltanschauungen are inevitably totalitarian. Everyone has the absolute weapon. However, it must be used with circumspection, like certain charms. If one approaches it from the standpoint of lies and oppression - back to front - then it is no more than bad clowning: an artistic consecration. The acts which destroy 
power are the same as the acts which construct free individual will but their range is different just as in strategy preparation for defense is obviously different from preparation for attack.

We haven't chosen the reversal of perspective through any kind of voluntarism. It has chosen us. Caught as we are in the historical phase of NOTHING, the next step can only be a change of EVERYTHING. Consciousness of total revolution, of its necessity, is our final way of being historical, our last chance, under certain conditions, of unmaking history. The game we are about to play is the game of our creativity. Its rules are radically opposed to the rules and laws controlling our society. It is a game of loser wins: what you are is more important than what is said, what is lived is more important than what is represented on the level of appearances. This game must be played right through to its conclusion. To cede an inch in one's will to live without reserve is to surrender all along the line. Those who give up their violence and their radical demands are doomed. Murdered truths become venomous, said Nietzsche. If we do not reverse perspective, then the perspective of power will succeed in turning us against ourselves once and for all. German Fascism was born in the blood of Spartacus. In each daily renunciation, reaction is preparing nothing less than the death of everyone. 


\section{Chapter 20. Creativity, Spontaneity, and Poetry}

Human beings are in a state of creativity twenty-four hours a day. Once revealed, the scheming use of freedom by the mechanisms of domination produces a backlash in the form of an idea of authentic freedom inseparably bound up with individual creativity. The passion to create which issues from the consciousness of constraint can no longer be pressed into the service of production, consumption or organization. (1). Spontaneity is the mode of existence of creativity; not an isolated state, but the unmediated experience of subjectivity. Spontaneity concretizes the passion for creation and is the first moment of its practical realization: the precondition of poetry, of the impulse to change the world in accordance with the demands of radical subjectivity. (2). The qualitative exists wherever creative spontaneity manifests itself. It entails the direct communication of the essential. It is poetry's chance. A crystallization of possibilities, a multiplier of knowledge and practical potential, and the proper modis operandi of intelligence. Its criteria are sui generis. The qualitative leap precipitates a chain reaction which is to be seen in all revolutionary moments; such a reaction must be awoken by the scandal of free and total creativity. (3). Poetry is the organizer of creative spontaneity to the extent that it reinforces spontaneity's hold on reality. Poetry is an act which engenders new realities; it is the fulfilment of radical theory, the revolutionary act par excellence.

\section{1}

In this fractured world, whose common denominator throughout history has been hierarchical social power, only one freedom has ever been tolerated: the freedom to change the numerator, the freedom to prefer one master to another. Freedom of choice so understood has increasingly lost its attraction - especially since it became the official doctrine of the worst totalitarianisms of the modern world, East and West. The generalization of the refusal to make such a Hobson's choice - to do no more than change employers - has in turn occasioned a restructuring of State power. All the governments of the industrialized or semi-industrialized world now tend to model themselves - after a single prototype: the common aim is to rationalize, to 'automate', the old forms of domination. And herein lies freedom's first chance. The bourgeois democracies have clearly shown that individual freedoms can be tolerated only insofar as they entrench upon and destroy one another; now that this is clear, it has become impossible for any government, no matter how sophisticated, to wave the muleta of freedom without everyone discerning the sword concealed behind it. In fact the constant evocation of freedom merely incites freedom to rediscover its roots in individual creativity, to break out of its official definition as the permitted the licit, the tolerable - to shatter the benevolence of despotism.

Freedom's second chance comes once it has retrieved its creative authenticity, and is tied up with the very mechanisms of Power. It is obvious that abstract systems of exploitation and domination are human creations, brought into being and refined through the diversion or co-optation 
of creativity. The only forms of creativity that authority can deal with, or wished to deal with, are those which the spectacle can recuperate. But what people do officially is nothing compared with what they do in secret. People usually associate creativity with works of art, but what are works of art alongside the creative energy displayed by everyone a thousand times a day: seething unsatisfied desires, daydreams in search of a foothold in reality, feelings at once confused and luminously clear, ideas and gestures presaging nameless upheavals. All this energy, of course, is relegated to anonymity and deprived of adequate means of expression, imprisoned by survival and obliged to find outlets by sacrificing its qualitative richness and conforming to the spectacle's categories. Think of Cheval's palace, the Watts Towers, Fourier's inspired system, or the pictorial universe of Douanier Rousseau. Even more to the point, consider the incredible diversity of anyone's dreams - landscapes the brilliance of whose colors qualitatively surpass the finest canvases of a Van Gogh. Every individual is constantly building an ideal world within themselves, even as their external motions bend to the requirements of soulless routine.

Nobody, no matter how alienated, is without (or unaware of) an irreducible core of creativity, a camera obscura safe from intrusion from lies and constraints. If ever social organization extends its control to this stronghold of humanity, its domination will no longer be exercised over anything save robots, or corpses. And, in a sense, this is why consciousness of creative energy increases, paradoxically enough, as a function of consumer society's efforts to co-opt it.

Argus is blind to the danger right in front of him. Where quantity reigns, quality has no legal existence; but this is the very thing that safeguards and nourishes it. I have already mentioned the fact that the dissatisfaction bred by the manic pursuit of quantity calls forth a radical desire for the qualitative. The more oppression is justified in terms of the freedom to consume, the more the malaise arising from this contradiction exacerbates the thirst for total freedom. The crisis of production-based capitalism pointed up the element of repressed creativity in the energy expended by the worker, and Marx gave us the definitive expose of this alienation of creativity through forced labor, through the exploitation of the producer. Whatever the capitalist system and its avatars (their antagonisms notwithstanding) lose on the production front they try to make up for in the sphere of consumption. The idea is that, as they gradually free themselves from the imperatives of production, people should be trapped by the newer obligations of the consumer. By opening up the wasteland of 'leisure' to a creativity liberated at long last thanks to reduced working hours, our kindly apostles of humanism are really only raising an army suitable for training on the parade ground of a consumption- based economy. Now that the alienation of the consumer is being exposed by the dialectic internal to consumption itself, what kind of prison can be devised for the highly subversive forces of individual creativity? As I have already pointed out, the rulers' last chance here is to turn us all into organizers of our own passivity.

With touching candour, Dewitt Peters remarks that, "If paints, brushes and canvas were handed out to everyone who wanted them, the results might be quite interesting". It is true that if this policy were applied in a variety of well-defined and well-policed spheres, such as the theatre, the plastic arts, music, writing, etc., and in a general way to any such sphere susceptible of total isolation from all the others, then the system might have a hope of endowing people with the consciousness of the artist, ie., the consciousness of someone who makes a profession of displaying their creativity in the museums and shopwindows of culture. The popularity of such a culture would be a perfect index of Power's success. Fortunately the chances of people being successfully 'culturized' in this way are now slight. Do they really imagine that people can be persuaded to engage in free experiment within bounds laid down by authoritarian decree? 
OR that prisoners who have become aware of their creative capacity will be content to decorate their cells with original graffiti? They are more likely to apply their newfound penchant for experiment in other spheres: firearms, desires, dreams, self- realization techniques. Especially since the crowd is already full of agitators. No: the last possible way of coopting creativity, which is the organization of artistic passivity, is happily doomed to failure.

"What I am trying to reach", wrote Paul Klee, "is a far-off point, at the sources of creation, where I suspect a single explanatory principle applies for people, animals, plants, fire, water, air and all the forces that surround us". As a matter of fact, this point is only far off in Power's lying perspective: the source of all creation lies in individual creativity; it is from this starting point that everything, being or thing, is ordered in accordance with poetry's grand freedom. This is the take-off point of the new perspective: that perspective for which everyone is struggling willy-nilly with all their strength and at every moment of their existence. "Subjectivity is the only truth" (Kierkegaard).

Power cannot enlist true creativity. In 1869 the Brussels police thought they had found the famous gold of the International, about which the capitalists were losing so much sleep. They seized a huge strongbox hidden in some dark corner. When they opened it, however, they found only coal. Little did the police know that the pure gold of the International would always turn into coal if touched by enemy hands.

The laboratory of individual creativity transmutes the basest metals of daily life into gold through a revolutionary alchemy. The prime objective is to dissolve slave consciousness, consciousness of impotence, by releasing creativity's magnetic power; impotence is magically dispelled as creative energy surges forth, genius serene in its self-assurance. So sterile on the plane of the race for prestige in the Spectacle, megalomania is an important phase in the struggle of the self against the combined forces of conditioning. The creative spark, which is the spark of true life, shines all the more brightly in the night of nihilism which at present envelopes us. As the project of a better organization of survival aborts, the sparks will become more and more numerous and gradually coalesce into a single light, the promise of a new organization based this time on the harmonizing of individual wills. History is leading us to the crossroads where radical subjectivity is destined to encounter the possibility of changing the world. The crossroads of the reversal of perspective.

\section{Spontaneity}

Spontaneity is the true mode of being of individual creativity, creativity's initial, immaculate form, unpolluted at the source and as yet unthreatened by the mechanisms of co- optation. Whereas creativity in the broad sense is the most equitably distributed thing imaginable, spontaneity seems to be confined to a chosen few. Its possession is a privilege of those whom long resistance to Power has endowed with a consciousness of their own value as individuals. In revolutionary moments this means the majority; in other periods, when the old mole works unseen, day by day, it is still more people than one might think. For so long as the light of creativity continues to shine spontaneity has a chance.

"The new artist protests", wrote Tzara in 1919. "He no longer paints: he creates directly." The new artists of the future, constructors of situations to be lived, will undoubtedly have immediacy as their most succinct - though also their most radical - demand. I say 'succinct' because 
it is important after all not to be confused by the connotations of the word 'spontaneity'. Spontaneity can never spring from internalized restraints, even subconscious ones, nor can it survive the effects of alienating abstraction and spectacular co-optation: it is a conquest, not a given. The reconstruction of the individual presupposes the reconstruction of the unconscious (cf the construction of dreams).

What spontaneous creativity has lacked up to now is a clear consciousness of its poetry. The commonsense view has always treated spontaneity as a primary state, and initial stage in need of theoretical adaptation, of transposition into formal terms. This view isolates spontaneity, treats it as a thing-in-itself - and thus recognizes it only in the travestied forms which it acquires within the spectacle (e.g. action painting). In point of fact, spontaneous creativity carries the seeds of a self- sufficient development within itself. It is possessed by its own poetry.

For me spontaneity is immediate experience, consciousness of a lived immediacy threatened on all sides yet not yet alienated, not yet relegated to inauthenticity. The centre of lived experience is that place where everyone comes closest to themself. Within this unique space-time we have the clear conviction that reality exempts us from necessity. Consciousness of necessity is always what alienates us. We have been taught to apprehend ourselves by default - in absentia, so to speak. But it takes a single moment of awareness of real life to eliminate all alibis, and consign the absence of future to the same void as the absence of past. Consciousness of the present harmonizes with lived experience in a sort of extemporization. The pleasure this brings us impoverished by its isolation, yet potentially rich because it reaches out towards an identical pleasure in other people - bears a striking resemblance to the enjoyment of jazz. At its best, improvisation in everyday life has much in common with jazz as evoked by Dauer: :The African conception of rhythm differs from the Western in that it is perceived through bodily movement rather than aurally. The technique consists essentially in the introduction of discontinuity into the static balance imposed upon time by rhythm and metre. This discontinuity, which results from the existence of ecstatic centres of gravity out of time with the musical rhythm and metre proper, creates a constant tension between the static beat and the ecstatic beat which is superimposed on it."

The instant of creative spontaneity is the minutest possible manifestation of reversal of perspective. It is a unitary moment, i.e., one and many. The eruption of lived pleasure is such that in losing myself I find myself; forgetting that I exist, I realize myself. Consciousness of immediate experience lies in this oscillation, in this improvisational jazz. By contrast, thought directed toward lived experience with analytical intent is bound to remain detached from that experience. This applies to all reflection on everyday life, including, to be sure, the present one. To combat this, all I can do is try to incorporate an element of constant self-criticism, so as to make the work of co-optation a little harder than usual. The traveller who is always thinking about the length of the road before them tires more easily than his or her companion who lets their imagination wander as they go along. Similarly, anxious attention paid to lived experience can only impede it, abstract it, and make it into nothing more than a series of memories-to-be.

If thought is really to find a basis in lived experience, it has to be free. The way to achieve this is to think other in terms of the same. As you make yourself, imagine another self who will make you one day in his or her turn. Such is my conception of spontaneity: the highest possible self-consciousness which is still inseparable from the self and from the world.

All the same, the paths of spontaneity are hard to find. Industrial civilization has let them become overgrown. And even when we find real life, knowing the best way to grasp it is not easy. 
Individual experience is also prey to insanity - a foothold for madness. Kierkegaard described this state of affairs as follows: "It is true that I have a lifebelt, but I cannot see the pole which is supposed to pull me out of the water. This is a ghastly way to experience things". The pole is there, of course, and no doubt everyone could grab onto it, though many would be so slow about it that they would die of anxiety before realizing its existence. But exist it does, and its name is radical subjectivity: the consciousness that all people have the same will to authentic self-realization, and that their subjectivity is strengthened by the perception of this subjective will in others. This way of getting out of oneself and radiating out, not so much towards others as towards that part of oneself that is to be found in others, is what gives creative spontaneity the strategic importance of a launching pad. The concepts and abstractions which rule us have to be returned to their source, to lived experience, not in order to validate them, but on the contrary to correct them, to turn them on their heads, to restore them to that sphere whence they derive and which they should never have left. This is a necessary precondition of people's imminent realization that their individual creativity is indistinguishable from universal creativity. The sole authority is one's own lived experience; and this everyone must prove to everyone else.

\section{The Qualitative}

I have already said that creativity, though equally distributed to all, only finds direct, spontaneous expression on specific occasions. These occasions are pre- revolutionary moments, the source of the poetry that changes life and transforms the world. They must surely be placed under the sign of that modern equivalent of grace, the qualitative. The presence of the divine abomination is revealed by a cloying spirituality suddenly conferred upon all, from the rustic to the most refined: on a cretin like Claudel as readily as on a St.John of the Cross. Similarly, a gesture, an attitude, perhaps merely a word, may suffice to show that poetry's chance is at hand, that the total construction of everyday life, a global reversal of perspective - in short, the revolution are immanent possibilities. The qualitative encapsulates and crystallizes these possibilities; it is a direct communication of the essential.

One day Kagame heard an old woman of Rwanda, who could neither read nor write, complaining: "Really, these whites are incurably simple-minded. They have no brains at all." "How can you be so stupid?" he answered her. "I would like to see you invent so many unimaginably marvellous things as the whites have done." With a condescending smile the old woman replied, "Listen, my child. They may have learned a lot of things, but they have no brains. They don't understand anything." And she was right, for the curse of technological civilization, of quantified exchange and scientific knowledge, is that they have created no means of freeing people's spontaneous creativity directly; indeed, they do not even allow people to understand the world in any unmediated fashion. The sentiments expressed by the Rwandan woman - whom the Belgian administrator doubtless looked upon, from the heights of his superior intelligence, as a wild animal - are also to be found, though laden with guilt and thus tainted by crass stupidity, in the old platitude: "I have studied a great deal and now know that I know nothing". For it is false, in a sense, to say that study can teach us nothing, so long as it does not abandon the point of view of the totality. What this attitude refuses to see, or to learn, are the various stages of the qualitative - whatever, at whatever level, lends support to the qualitative. Imagine a number of apartments located immediately above one another, communicating directly by means of a central elevator 
and also indirectly linked by an outside spiral staircase. People in the different apartments have direct access to each other, whereas someone slowly climbing the spiral stairs is cut off from them. The former have access to the qualitative at all levels; the latter's knowledge is limited to one step at a time, and so no dialogue is possible between the two. Thus the revolutionary workers of 1848 were no doubt incapable of reading the Communist Manifesto, yet they possessed within themselves the essential lessons of Marx and Engels' text. In fact this is what made the Marxist theory truly radical. The objective conditions of the worker, expressed by the Manifesto on the level of theory, made it possible for the most illiterate proletarian to understand Marx immediately when the moment came. The cultivated person who uses their culture like a flame thrower is bound to get on with the uncultivated person who experiences what the first person puts in scholarly terms the lived reality of everyday life. The arms of criticism do indeed have to join forces with criticism by force of arms.

Only the qualitative permits a higher stage to be reached in one bound. This is the lesson that any endangered group must learn, the pedagogy of the barricades. The graded world of hierarchical power, however, can only envisage knowledge as being similarly graded: the people on the spiral staircase, experts on the type and number of steps, meet, pass, bump into one another and trade insults. What difference does it make? At the bottom we have the autodidact gorged on platitudes, at the top the intellectual collecting ideas like butterflies: mirror images of foolishness. The opposition between Miguel de Unamuno and the repulsive Millan Stray, between the paid thinker and their reviler, is an empty one: where the qualitative is not in evidence, intelligence is a fool's cap and bells.

The alchemists called those elements needed for the Great Work the materia prima. Paracelsus' description of this applies perfectly to the qualitative: "It is obvious that the poor possess it in greater abundance than the rich. People squander the good portion of it and keep only the bad. It is visible and invisible, and children play with it in the street. But the ignorant crush it underfoot everyday." The consciousness of this qualitative materia prima may be expected to become more and more acute in most minds as the bastions of specialized thought and gradated knowledge collapse. Those who make a profession of creating, and those whose profession prevents them from creating, both artists and workers, are being pushed into the same nihilism by the process of proletarianization. This process, which is accompanied by resistance to it, i.e., resistance to co-opted forms of creativity, occurs amid such a plethora of cultural goods - records, films, paperback books - that once these commodities have been freed from the laws of consumption they will pass immediately into the service of true creativity. The sabotage of the mechanisms of economic and cultural consumption is epitomized by young people who steal the books in which they expect to find confirmation of their radicalism.

Once the light of the qualitative is shed upon them, the most varied kinds of knowledge combine and form a magnetic bridge powerful enough to overthrow the weightiest traditions. The force of plain spontaneous creativity increases knowledge at an exponential rate. Using makeshift equipment and negligible funds, a German engineer recently built an apparatus able to replace the cyclotron. If individual creativity can achieve suck results with such meagre stimulation, what marvels of energy must be expected from the qualitative shock waves and chain reactions that will occur when the spirit of freedom still alive in the individual re-emerges in collective form to celebrate the great social fete, with its joyful breaking of all taboos.

The job of a consistent revolutionary group, far from being the creation of a new type of conditioning, is to establish protected areas where the intensity of conditioning tends toward zero. 
Making each person aware of their creative potential will be a hapless task unless recourse is had to qualitative shock tactics. Which is why we expect nothing from the mass parties and other groupings based on the principle of quantitative recruitment. Something can be expected, on the other hand, from a micro- society formed on the basis of the radical acts or thought of its members, and maintained in a permanent state of practical readiness by means of strict theoretical discrimination. Cells successfully established along such lines would have every chance of wielding sufficient influence one day to free the creativity of the majority of the people. The despair of the anarchist terrorist must be changed into hope; those tactics, worthy of some medieval warrior, must be changed into a modern strategy.

\section{Poetry}

What is poetry? It is the organization of creative spontaneity, the exploitation of the qualitative in accordance with its internal laws of coherence. Poetry is what the Greeks called poiein, 'making', but 'making' restored to the purity of its moment of genesis - seen, in other words, from the point of view of the totality.

Poetry cannot exist in the absence of the qualitative. In this absence we find the opposite of the qualitative: information, the transitional programme, specialization, reformism - the various guises of the fragmentary. The presence of the qualitative does not of itself guarantee poetry, however. A rich complex of signs and possibilities may get lost in confusion, disintegrate from lack of coherence, or be destroyed by crossed purposes. The criterion of effectiveness must remain supreme. Thus poetry is also radical theory completely embodied in action; the mortar binding tactics and revolutionary strategy; the high point of the great gamble on everyday life.

What is poetry? In 1895, during an ill-advised and seemingly foredoomed French railway worker's strike, one trade unionist stood up and mentioned and ingenious and cheap way of advancing the strikers' cause: "It takes two sous' worth of a certain substance used in the right way to immobilize a locomotive". Thanks to this bit of quick thinking, the tables were turned on the government and capitalists. Here it is clear that poetry is the act which brings new realities into being, the act which reverses the perspective. The materia prima is within everyone's reach. Poets are those who know how to use it to best effect. Moreover, two sous' worth of some chemical is nothing compared with the profusion of unrivalled energy generated and made available by everyday life itself: the energy of the will to live, of desire unleashed, of the passions of love, the power of fear and anxiety, the hurricane of hatred and the wild impetus of the urge for destruction. What poetic upheavals may confidently be expected to stem from such universally experienced feelings as those associated with deaths, old age, and sickness. The long revolution of everyday life, the only true poetry-made-by-all, will take this still marginal consciousness as its point of departure.

"What is poetry?", ask the aesthetes. And we may as well give them the obvious answer right away: poetry rarely involves poems these days. Most art works betray poetry. How could it be otherwise, when poetry and power are irreconcilable? At best, the artist's creativity is imprisoned, cloistered, within an unfinished oeuvre, awaiting the day when it will have the last word. Unfortunately, no matte how much importance the artist gives it, this last word, which is supposed to usher in perfect communication, will never be pronounced so long as the revolt of creativity has not realized art. 
The African work of art - poem, music, sculpture, or mask - is not considered complete until it has become a form of speech, a word-in-action, a creative element which functions. Actually this is true for more than African art. There is no art in the world which does not seek to function; and to function - even on the level of later co-optation - consistently with the very same will which generated it, the will to live constantly in the euphoria of the moment of creation. Why is it that the work of the greatest artists never seems to have an end? The answer is that great art cries out in every possible way for realization, for the right to enter lived experience. The present decomposition of art is a bow perfectly readied for such an arrow.

Nothing can save past culture from the cult of the past except those pictures, writings, musical or lithic architectures, etc., whose qualitative dimension gets through to us free of its form - of all art forms. This happens with Sade and Lautréamont, of course, but also with Villon, Lucretius, Rabelais, Pascal, Fourier, Bosch, Danté, Bach, Swift, Shakespeare, Uccello, etc. All are liable to shed their cultural chrysalis, and emerge from the museums to which history has relegated them to become so much dynamite for the bombs of the future realizers of art. Thus the value of an old work of art should be assessed on the basis of the amount of radical theory that can be drawn from it, on the basis of the nucleus of creative spontaneity which the new creators will be able to release from it for the purpose, and by means of an unprecedented kind of poetry.

Radical theory's forte is its ability to postpone an action begun by creative spontaneity without mitigating it or redirecting its thrust. Conversely, the artistic approach seeks in its finest moments to stamp the world with the impress of a tentacular subjective activity constantly seeking to create, and to create itself. Whereas radical theory sticks close to poetic reality, to reality in process and to the world as it is being changed, art takes an identical tack but at much greater risk of being lost and corrupted. Only an art armed against itself, against its own weaker side its most aesthetic side - has any hope of evading co-optation.

Consumer society, as we well know, reduces art to a range of consumable products. The more vulgarized this reduction, the faster the rate of decomposition and the greater the chances for transcendence. That communication so urgently sought by the artist is cut off and prohibited even in the simplest relationships of everyday life. So true is this that the search for new forms of communication, far from being the preserve of painters and poets, is now part of a collective effort. In this way the old specialization of art has finally come to an end. There are no more artists because everyone is an artist. The work of art of the future will be the construction of a passionate life.

The object created is less important than the process which gives rise to it, the act of creating. What makes an artist is their state of creativity, not art galleries. Unfortunately, artists rarely recognize themselves as creators: most of the time they play to the gallery, exhibitionistically. A contemplative attitude before a work of art was the first stone thrown at the creator. They encouraged this attitude in the first place, but today it is their undoing: now it amounts to no more than a need to consume, an expression of the crassest economic imperatives. This is why there is no longer any such thing as a work of art in the classical sense of the word. Nor can there be such a thing. So much the better. Poetry is to be found everywhere: in the facts, in the events we bring about. The poetry of the facts, formerly always treated as marginal, now stands at the centre of everyone's concerns, at the centre of everyday life, a sphere which as a matter of fact it has never left.

True poetry cares nothing for poems. In his quest for the Book, Mallarmé wanted nothing so much as to abolish the poem. What better way could there be of abolishing the poem than 
realizing it? And indeed a few of Mallarmé's contemporaries proved themselves rather brilliant exponents of just such a 'new poetry'. Did the author of Herodiade have an inking, perhaps, when he described them as "angels of purity", that the anarchists with their bombs offered the poet a key which, walled up in his words, he could never use?

Poetry is always somewhere. Its recent abandonment of the arts makes it easier to see that it resides primarily in individual acts, in a lifestyle and in the search for such a style. Everywhere repressed, this poetry springs up everywhere. Brutally put down, it is reborn in violence. It plays muse to rioters, informs revolt and animates all great revolutionary carnivals for a while, until the bureaucrats consign it to the prison of hagiography.

Lived poetry has effectively shown throughout history, even in partial revolts, even in crime - which Coeurderoy so aptly dubbed the "revolt of one" - that it is the protector par excellence of everything irreducible in mankind, i.e., creative spontaneity. The will to unite the individual and the social, not on the basis of an illusory community but on that of subjectivity - this is what makes the new poetry into a weapon which everyone must learn to handle by themself. Poetic experience is henceforth at a premium. The organization of spontaneity will be the work of spontaneity itself. 


\section{Chapter 21. Masters Without Slaves}

Power is the social organisation which enables masters to maintain conditions of slavery. God, State, Organisation: these three words reveal well enough the amount of autonomy and historical determination there is in power, three principles have successively held sway: the domination principle (feudal power), the exploitation principle (bourgeois power) and the organisation principle (cybernetic power) (2). Hierarchical social organisation has perfected itself by desacralisation and mechanisation, but its contradictions have increased. it has humanised itself to the extent that it has emptied men of their human substance. it has gained in autonomy at the expense of the masters; (the rulers are in control but it's the strings that make them dance), today, those in power are perpetuating the race of willing slaves, those whom Theognis said were born with bowed heads, they have lost even the unhealthy pleasures of domination. Facing the masters/slaves stand the men of refusal, the new proletariat, rich in revolutionary traditions. From these the masters without slaves will emerge, together with a superior type of society in which the lived project of childhood and the historical project of the great aristocrats will be realised (l) (3).

\section{1}

In the Theages Plato writes: "Each man would like if posslble to be the master of all men. Or, better still, God." A mediocre ambition in view of the weakness of masters and gods. For if, in the last analysis, the pettiness of slaves derives from the allegiance to their rulers, the pettiness of rulers and of God Himself comes from deficiencies in the nature of those ruled. The master knows alienation by its positive pole, the slave by its negative pole; total mastery is equally refused both of them.

How does the feudal lord behave in this dialectic of master and slave? Slave of God and master of men - and master of men because he is slave of God, as the myth would have it - we see him condemned to blend within himself the disgust and respectful interest that he has before God, for it is to God that he owes his obedience, and it is from him that he derives his power over men. In short, he reproduces between God and himself the type of relationship that exists between nobles and king. What is a king? A chosen one among the chosen, and one whose succession generally occurs as a game in which equals compete. Feudal lords serve the king, but they serve him as his equals in power, they submit themselves to God in the same way as rivals and competitors.

One can understand why the masters of old were unsatisfied. Through God they enter into the positive pole of alienation; through those they oppress, into its negative pole. What desire could they have to be God, knowing the boredom of positive alienation? And at the same time, how could they not want to rid themselves of God, the tyrant over them? The "To be or not to be" of great men has always been expressed by the question, insoluble in their epoch, of how to deny God, and yet preserve Him, that is, to supersede and realize Him.

History bears witness to two practical attempts at such a supersession: that of the mystics and that of the great refusers. Meister Eckhart declared: "1 pray God to absolve me from God". 
Similarly, the Swabian heretics of 1270 said that they had raised themselves above God, and that, having attained the highest degree of divine perfection, they had abandoned Him. On another tack, the negative tack, certain strong personalities like Elogabalus, Gilles de Rais and Erszebet Bathory, strove, as one can see, to attain a total mastery over the world by the liquidation of intermediaries, those who were alienating them positively, their slaves. They approached the total man via a total inhumanity. "Against Nature". So the passion for an unbounded rule and the absolute refusal of constraints form the same single route, an ascending and descending road on which Caligula and Spartacus, Gilles de Rais and Dosza Gyorgy stand side by side, together yet separate. However, it is not enough to say that the integral revolt of slaves - I insist the integral revolt, and not its deficient forms whether Christian, bourgeois or socialist - unites with the extreme revolt of the masters of old. In fact, the will to abolish slavery and all its sequels (the proletariat, servants, submissive and passive men) offers a unique chance to the will to rule the world with no other limit than a reinvented nature, and the resistance of objects to their own transformation.

That chance is inscribed in the historical process. History exists because the oppressed exist. The struggle against nature, and then against the different social organisations of the struggle against nature, is always the struggle for human emancipation, for the total man. The refusal to be a slave is really what changes the world.

So what is the goal of history? History is made "under certain conditions" (Marx) by slaves against slavery. Thus it can only pursue one aim: the destruction of masters. For his part, the master never stops trying to escape from history, to refuse it by massacring those who make it, and who make it against him.

Some paradoxes:

1. The most human aspect of the masters of old resides in their claim to absolute mastery. Such a project implies the absolute blockage of history, and thus the extreme refusal of emancipation. That is to say, total inhumanity.

2. The desire to escape from history makes you vulnerable. If you try to flee you lose your cover, and are more easily attacked; a determined immobility can no more resist waves of attack by lived reality than it can the dialectic of productive forces. The masters are the sacrificial victims of history; from the height of the pyramid of the present, contemplating three thousand years of history, one can see them crushed by it, either in terms of a definite plan, a strict programme, or a line of force which allows one to conceive of a Sense of History (the end of the slave world, the feudal world and the bourgeois world).

Because they try to escape it, the masters slot themselves tidily in the drawers of history: they enter into linear temporal evolution in spite of themselves. On the other hand, those who make history, the revolutionaries, slaves drunk with total freedom, seem to act "sub specie aeternitatis", under the sign of the intemporal, driven by an insatiable taste for an intense life, pursuing their aim through various historical conditions. Perhaps the philosophical notion of eternity is linked with historical attempts at emancipation,.. perhaps this notion will one day be realised, like philosophy, by those who carry within them total freedom and the end of traditional history.

3. The superiority of the negative pole of alienation over the positive pole is that its integral revolt makes the project of absolute mastery the only solution. Slaves in struggle for the 
abolition of constraints reveal the moment through which history liquidates masters, and beyond history, there is the possibility of a new power over the things that they encounter, a power which no longer appropriates objects by appropriating people. But in the very course of a slowly elaborated history, it has been inevitable that the masters, instead of disappearing, have degenerated; there are no longer any masters, only slave-consumers of power, differing among themselves only in the degree and quantity of power consumed.

The transformation of the world by the productive forces was bound slowly to realise the material conditions of total emancipation, having first passed through the stage of the bourgeoisie. Today, when automation and cybernetics applied in a human way would permit the construction of the dream of masters and slaves of all time, there only exists a socially shapeless magma which blends in each individual paltry portions of master and slave. Yet it is from this reign of equivalent values that then new masters, the masters without slaves, will emerge.

I want in passing to hail de Sade. He is, as much by his privileged appearance at a turning point in history as by his astounding lucidity, the last of the great aristocrats in revolt. How do the masters of the Chateau of Selling assure their absolute mastery? They massacre all their servants and reach an eternity of delight by this gesture. This is the subject of 120 Days of Sodom.

Marquis and sans-culotte, D.A.F. de Sade unites the perfect hedonist logic of the grand seigneur badman and the revolutionary desire to enjoy without limitations a subjectivity which is at last freed from the hierarchical framework. The desperate effort he makes to abolish both positive and negative poles of alienation ranges him at once among the most important theoreticians of the total man. Its high time that revolutionaries were reading de Sade with the same care that they set about reading Marx. (Of Marx, as we know, the revolutionary specialists know mostly what he wrote under the pseudonym of Stalin, or at best of Lenin and Trotsky.) At any rate, nobody who wants to change daily life radically will be able from now on to ignore either the great refusers of power, or those masters of old who came to feel cramped in the power that God granted them.

2

Bourgeois power fed on the crumbs of feudal power. It is crumbled feudal power. Eaten away by revolutionary criticism, trodden underfoot and broken up, (without this liquidation ever reaching its logical conclusion - the end of hierarchical power), aristocratic authority survived the death of the aristocracy in the form of parody, the pain-stricken grin. Awkward and stiff in their fragmentary power, making their fragment a totality (and the totalitarian is nothing else), the bourgeois rulers were condemned to see their prestige fall apart at the seams, rotted by the decomposition of the spectacle. As soon as myth and authority lost their credibility, the form of government could only be either burlesque terror or democratic bullshit. O look at Napoleon's pretty children! Louis Philippe, Napoleon III, Thiers, Alphonse XIII, Hitler, Mussolini, Stalin. Franco, Salazar, Nasser, Mao, de Gaulle... ubiquitous Ubus in the four corners of the world spawning more and more cretinous miscarriages. Yesterday they still brandished their twigs of authority like Olympian thunderbolts; today the apes of power glean no more from the social scene than a little dubious respect. Certainly, the absurdity of a Franco is still lethal - no-one would dream 
of forgetting it - but one should always remember that the stupidity of power will be a deadlier killer than stupidity in power.

The spectacle is the brainscrambling machine of our penal colony, The master-slaves of today are its faithful servants, the extras and stage-managers. Who will want to judge them? They will plead not guilty and in fact they aren't really guilty. They don't need cynicism so much as spontaneous confessions, terror so much as acquiescent victims, or force so much as herds of masochists. The alibi of the rulers lies in the cowardice of the ruled. But now everyone is governed, manipulated as things by an abstract power, by an organisation-in-itself whose laws are imposed on the self-styled rulers. Things are not judged, they are just stopped from being a nuisance.

In October 1963 Monsieur Fourastié reached the following conclusions on the subject of the future leader: "The leader has lost his almost magical power; he is and will be a man capable of provoking actions. Finally, a reign of workgroups will develop to prepare decisions. The leader will be a committee president, but one who knows how to sum up and make decisions." (My italics). You can see the three historical phases characterising the evolution of the master:

1. The principle of domination, linked with feudal society.

2. The principle of exploitation, linked with bourgeois society.

3. The principle of organisation, linked with cybernetic society.

In fact, the three elements are inseparable; one cannot dominate without exploiting and organising at the same time; but their importance varies with the epoch. As one passes from one stage to the next, the autonomy and the role of the master wane and diminish. The humanity of the master tends towards zero, while the inhumanity of disembodied power tends towards infinity.

According to the principle of domination, the master refuses slaves an existence which would limit his own. With the principle of exploitation, the boss allows the workers an existence which fattens and develops his own. The principle of organisation classifies individual existences like fractions, according to their managerial or executive faculties. (A shop-steward would, for example, be defined in terms of long calculations involving his productivity, his representativeness, etc., as 56 per cent directing function, 40 per cent executive function and 4 per cent ambiguity, as Fourier would have said.)

Domination is a right, exploitation a contract, organisation an order of things. The tyrant dominates according to his will to power, the capitalist exploits according to the laws of profit, the organiser plans and is planned. The first wants to be arbitrary, the second just, the third rational and objective. The aristocrat's inhumanity is a humanity seeking itself; the exploiter's inhumanity tries to disguise itself by seducing humanity with technical progress, comfort and the struggle against hunger and disease; the cybernetician's inhumanity is the inhumanity which accepts itself. In this manner, the master's inhumanity has become less and less human. A systematic extermination camp is far more horrifying than the murderous fury of feudal barons throwing themselves into gratuitous war. And what lyricism there still is even in the massacres of Auschwitz compared with the icy hands of generalised conditioning which the cyberneticians' technocratic organisation reach out towards the future society, that is so close!

Make no mistake: it's not a matter of choosing between the "humanity" of a lettre de cachet and the "humanity" of a brain-washing. That's the choice between being hanged and being shot! 
I simply mean that the dubious pleasures of dominating and crushing underfoot tend to disappear. Capitalism formally introduced the need to exploit men without passionately enjoying it. No sadism, no negative joy of inflicting pain, no human perversion, not even the man "against nature". The reign of things is accomplished. In renouncing the hedonist principle, the masters have renounced mastery. It is the task of the masters without slaves to correct this self-denial.

What the society of production sowed is reaped today by the dictatorship of the consumable. Its principle of organisation merely perfects the real mastery of dead things over men. Whatever power remained to the owners of the instruments of production disappeared when their machines escaped them and passed under the control of the technicians who organise their use. Meanwhile, the organisers themselves are gradually ingested by the charts and programmes which they have so carefully worked out. The simple machine wil1 be the leader's last justification, the last support for his last trace of humanity. Cybernetic organisation of production and consumption must necessarily control, plan and rationalise daily life.

These small-time masters are the specialists, masters/ slaves who pullulate all over daily life. No one need worry, they don't stand a chance. Already by 1867, at the Congress of Basel. Francau, a member of the First International, was declaring: "We've been towed along by marquesses of diplomas and princes of science for far too long. Let's look after our own affairs and however inept we are we can't make more of a mess than what they've done in our name." Ripe words of wisdom, whose meaning grows as specialists proliferate and encrust individual life. Those who succumb to the magnetic attraction exercised by the huge Kafkaesque cybernetic machine are nicely divided from those who follow their own impulses and try to escape from it. The latter are the trustees of everything human, since from now on nobody can lay any clalm to it in the name of the masters of old. There are only things falling at the same speed in a vacuum on the one hand, and, on the other, the age-old project of slaves drunk with total freedom.

\section{3}

The master without slaves, or the aristocratic supersession of the aristocracy. The master lost out in the same way as God. He topples like a Golem the moment he stops loving mankind, and thus the moment he ceases to enjoy indulging his pleasure of oppressing them. That's when he abandons hedonism. There is little fun just moving things around, dealing with being inert as bricks. With fine discernment. God seeks out living creatures with smooth palpitating flesh whose souls shiver in terror and respect. To confirm His own grandeur, He needs to feel the presence of His subjects, fervent in prayer, competition, cunning, and even insult. The Catholic God is quite good at lending out a little genuine freedom, in the manner of a pawnbroker. Like a cat with a mouse, He lets men alone, until the Last Judgment when He'll gobble them up. Then, towards the close of the Middle Ages when the bourgeoisie enters on the scene, we see Him humanising Himself; paradoxically, for He is becoming an object, just as each man is. When He condemns men to predestination, Calvin's God loses the pleasure of arbitrariness: He's no longer free to crush whom He will, nor when He will. The God of commercial transactions, humourless, as cold and calculated as a discount rate, is ashamed; He hides away. Deus absconditus. The dialogue is broken. Pascal despairs. Descartes does not know what to do with a soul that is suddenly unattached. Later - too late - Kierkegaard will attempt to resuscitate the subjective God by resuscitating men's subjectivity. But nothing can bring God back to life once He has become in men's minds 
"the great external object"; He is definitely dead, turned to stone, like coral. Moreover, mankind, caught in the rigor mortis of His last embrace (the hierarchical form of power), seems doomed to reification, the death of what's human. The perspective of power offers our gaze nothing but things, fragments of the great divine rock. Isn't it according to this perspective that sociology, psychology, economics, and the so-called "human" sciences - so anxious to observe "objectively" - focus their microscopes?

What forces the master to abandon his hedonism? What prevents him reaching total enjoyment if not his position as master, his prejudice for hierarchical superiority? That renunciation grows greater as hierarchy fragments, as masters multiply and shrink in status, as history democratises power. The imperfect enjoyment of the masters has become the enjoyment of imperfect masters. We have seen the bourgeois masters, Ubuesque plebians, crown their beerhall revolt with the funeral festivity of Fascism. But there will be no more festivities among the masters/slaves, among the last of hierarchical man; only the sadness of things, a gloomy placidity, uneasy role-playing, the awareness of "belng nothing".

What will become of these things that govern us? Must we destroy them? Given an affirmative, those best prepared to liquidate the slaves-in-power are those who've been struggling against slavery all along. Popular creativity, which neither lords nor bosses have managed to break, will never kow-tow to programmatic necessity and technocrats' plans. You might object that less passion and enthusiasm are aroused by liquidating an abstract form and a system than by executing detested masters; that's to see the problem in the wrong light, the light of power. Unlike the bourgeoisie, the proletariat does not define itself in terms of its class enemy; it brings the end of class distinction and hierarchy. The role of the bourgeoisie was uniquely negative. Saint-Just captures it superbly: "What constitutes a republic is the total destruction of what opposes it."

If the bourgeoisie is content with forging weapons against feudalism and therefore against itself, the proletariat, on the other hand, contains its own possible supersession. It is poetry momentarily alienated by the ruling class or technocratic organisation, but always on the point of bursting out. As the sole trustee of the will to live since it has felt to the full how intolerable is mere survival, the proletariat will break the wall of constralnts by the breath of its pleasure and the spontaneous violence of its creativity. It already possesses all the joy to be had and all the laughter to offer. It draws its strength and passion from itself. What it is preparing to build will in addition destroy all that opposes it just as a new tape recording erases the previous one. The proletariat will abolish itself at the same instant that it abolishes the power of things, with luxuriance, a trace of nonchalance and the grace worn by the man who has proved his superiority. The masters wlthout slaves will emerge from the new proletariat; not the conditioned robots of humanism that the self-styled 'revolutionary' leftist onanists dream about. The insurrectional violence of the masses is only one aspect of the proletariat's creativity, its impatience to abolish itself, as strong as its desires to carry out the sentence that survival pronounces upon itself.

I like to distinguish - a specious distinction - three predominant passions in the destruction of the reified order.

- The passion for absolute power, exercised over objects placed immediately at the service of men; without the mediation of men themselves. It's therefore the destruction of those hooked on the order of things, the slave-owners of fragmented power. "Because we can no longer stand the sight of slaves, we suppress them." (Nietzsche) 
- The the passion to destroy constraints, to smash the chains. As De Sade says: "Can lawful pleasure compare with the delights which combine far more piquant attractions with the inestimable joy of breaking social constraints and overthrowing all laws?"

- The passion to straighten out a miserable past, to re-excite old disappointed hopes as much in each individual life as in the history of crushed revolutions. Just as once it was legitimate to punish Louis XVI for the crimes of his predecessors, so today there's no lack of passionate reasons, as it's impossible to take revenge on things, to wipe out the memory of the executed Communards, the torture of the peasants of 1525, the assassination of workers, revolutionaries hunted down and shot, civilisations obliterated by colonialism, so much pain in free souls from past misery that the present has never eradicated. The correction of history has become passionate because it is possible: to swamp the blood of Babeuf, Lacenaire, Ravachol and Bonnot in the blood of the hidden descendants of those who, as slaves of an order founded on profit and economic mechanisms, thought to put cruel checks on human emancipation.

The pleasure of overthrowing power, being master-without-slaves and righting the past is what lies uppermost in the subjectivity of each of us. In the revolutionary moment, every man is invited to make his own history himself. Freedom of realization as a cause, while ceasing to be a cause, always espouses subjectivity. Only such a perspective can loosen the riot of intoxicating possibilities and the giddy feeling when every delight is within the grasp of all.

Take care that the old order of things doesn't collapse on the heads of those demolishing it. The avalanche of the consumable could drag us down in the final fall if people don't take care to arrange collective shelters against the conditioning of the spectacle and hierarchical organisation; shelters from which further offensives will be launched. The microsocieties that are now forming will realise the former masters' project as they free it from its hierarchical mould. The supersession of the "grand seigneur bad man" will apply to the letter that admirable principle of Keats: "Everything that can be annihilated must be annihilated so that children may be saved from slavery".

This supersession must operate simultaneously on three levels:

1. Supersession of patriarchal organisation.

2. Supersession of hierarchical power.

3. Supersession of the arbitrarily subjective, the authoritarian whim.

1

Lineage contains the magic strength of the aristocracy, the energy transmitted from generation to generation. By undermining feudal mastery, the bourgeoisie was led against its will to undermine the family. And it acts the same way towards the organisation of society... I've already said that this very negativity surely represents its richest, most 'positive', aspect. But what 
the bourgeoisie lacks is the possibility of supersession. What would the supersession of an aristocratic type of family imply? We would have to answer: the formation of coherent groups where individual creativity is totally invested in collective creativity and strengthened by it; where the immediacy of the lived present takes over the energy potential which in feudal times derived from the past. The relative weakness of the master paralysed by his own hierarchical system brings to mind the weakness of the child brought up within the bourgeois family framework.

The child acquires a subjective experience of freedom unknown to any other animal species. but he remains for all that subjectively dependent upon his parents - he needs their care and their solicitude. What differentiates child from animal is that the child possesses a feeling of the continuous transformation of the world, or poetry, to an unlimited degree. At the same time he is denied access to the techniques that adults use most of the time against such poetry, for example against children by conditioning them. And when children, in their maturity, finally acquire the techniques, they have lost, under the weight of constraints, what made their childhood superior. The universe of the masters of old falls under the same curse as the universe of children: they have no access to the techniques of liberation. Consequently they are condemned to dream of world transformation and live according to the laws of adaptation to it. One was quite justified in believing that hierarchical organisation was the best means of concentrating social energy in a world where that energy didn't enjoy the valuable support of machinery. But once the bourgeoisie develops highly effective techniques for transforming the world, then hierarchical power becomes anachronistic, and acts like a brake on the development of human power over the world. The hierarchical system, man's power over man, prevents the recognition of worthwhile adversaries, thwarting the real transformation of one's surroundings. Instead, it just saddles one with the need to adapt to the environment and conform to the state of things. That's why:

2

In order to smash the social screen that messes up our vision, we postulate the categorical rejection of any hierarchy within the group. The very notion of the dictatorship of the proletariat deserves attention. On most occasions, the dictatorship of the proletariat turns into dictatorship over the proletariat, and becomes institutionalized. Now, as Lenin wrote: "The dictatorship of the proletariat is a relentless struggle, both bloody and bloodless, violent and peaceful, military and economic, educational and administrative, against the forces and tradition of the Old World." The proletariat cannot set up a lasting domination, since it cannot exercise a dictatorship that no-one wants. Conversely, the absolute need to smash the enemy obliges it to concentrate in its hands a strongly coherent repressive power. So it's a matter of passing through a dictatorship that itself negates itself, as the party "whose victory must also be its defeat", the proletariat itself. The proletariat, through its dictatorship, must immediately make its own negation its first priority. It has no choice but to liquidate, in a short space of time, bloodily or not as circumstances permit, those who stand in the way of its project of total freedom and those who oppose the ending of its existence as proletariat. It must utterly destroy them as vermin. Every single individual must root out the slightest inclination for prestige and the most trivial hierarchical pretensions, and raise against these roles a calm impetus towards authentic life. 
The end of roles means the triumph of subjectivity. Once this subjectivity is finally recognized and set at the centre of concern, contradictorily it brings a new objectivity into being. A new world of objects, or, if you prefer, a new nature, will create itself out of the needs of individual subjectivity. Here too a relationship is established between childhood's perspective and that of the feudal masters. In the one as in the other, even though in a completely different manner, the possibilities are masked by the screen of social alienation.

Who can have forgotten? Childhood solitudes would open on primaeval vastness, and every stick was a magic wand. Then we had to adapt, become social and sociable. The solitude was depopulated, the children chose despite themselves to grow old, and the vastness closed up like a story book. Nobody in this world completely escapes the sewers of puberty. Childhood itself is slowly colonised by consumer society. Those under ten join "teen-agers" in the great consumer family and grow older faster as "junior consumers'. It's impossible at this point not to feel the similarity between the historical dethronement of the masters of old and the growing decadence of the kingdom of childhood. Never before has the corruption of humanity reached such an intensity. Never before have we been so near and yet so far from the total man.

The caprices of the masters of old, the lords, were insidiously inferior to the whims of the child, for they demanded the repression of other men. Whatever subjectivity there is in feudal arbitrariness - as I choose I shall give you riches or death - is spoilt and fettered by the poverty of its realisation. The master's subjectivity is only realised by denying the subjectivity of others, and thus by loading itself with chains; it chains itself by chaining others.

The child does not have this privilege of imperfection. In one fell swoop he loses his right to pure subjectivity. He's taunted with childishness, encouraged to behave like a grown-up. Any everyone grows up, suppressing his childhood to the point where cretinism and death pangs convince him that he's managing to live like an adult.

The child's game like that of the great noble, needs to be freed and given the honour it is due. Today, the moment is historically favourable. It's a matter of saving childhood and its sovereign subjectivity, childhood and the laughter which is like the rippling of spontaneity, childhood and its way of relying upon itself to light up the world, and the objects within it, in a strangely familiar light - by realizing the project of the masters of old.

We have lost the beauty of things, their way of existing, by letting them die at the hands of power and the gods. Surrealism's magnificent dream tried in vain to bring them back to life and suffuse them with poetry. But the power of imagination alone is not enough to shatter the framework in which social alienation imprisons things, for it doesn't return them to the free play of subjectivity. In the light of power, a stone, a tree, a concrete mixer, or a cyclotron are dead objects, crosses planted on the will to see them differently and change them. And yet, beyond what they have been made to mean, I know I shall find their exhilaration again. I know what emotion a machine can awaken when brought into the game, into fantasy and freedom. In a world where everything is alive, including trees and rocks, nothing is just passively contemplated. Everything speaks of joy. Subjectivity's triumph gives everything life; and isn't the fact that dead things exercise an intolerable domination over subjectivity really the best chance, historically, of arriving at a superior way of life?

What does it take? The realisation in today's language - that is to say, praxis - of what a heretic once declared to Ruysbroeck : "God can know, wish, do nothing without me. With God 
I have created myself and I have created all things, and it is my hand that supports heaven and earth and all creatures. Without me nothing exists."

We must discover new frontiers. If the bounds of social alienation still imprison us, at least they no longer deceive us. For centuries men have remained before a wormeaten door, piercing little pin-holes in it with growing ease. One kick is now enough to knock it down, and that's when everything begins. The proletariat's problem is no longer to seize power, but to put a definite end to it. On the other side of the hierarchical world, the possibilities come to meet us. The primacy of life over survival will be the historical movement which will unmake history. We have yet to invent worthwhile adversaries. It is up to us to find them, and to join them through the lookingglass of childhood.

Will we see men resume the cosmic communication that the first inhabitants of the earth must have known, only this time on a higher level reaching way above prehistory, and without the fearful trembling of early man defenceless before its mystery? In short, will men impose a human meaning on the universe which would most beneficially replace the divine meaning with which it was invested at the dawn of time?

And this other infinite, man as he really is? Could he not one day govern his body, this constant flow of nerves, his beautiful muscular system and his wayfaring through dreams? Couldn't the exploits of individual will finally freed by collective will get beyond the already sinister degree of control that police conditioning can impose on the human being? We know how to make a dog. a brick and a cop out of a man; do we know how to make a man?

We have never really believed our infallibility. We have left that claim - out of pride perhaps - to unalterable forms and wrinkled old men: power, God, the Pope, the boss, the others. And yet every time we refer to Society, God, or All-powerful Justice, we're really talking about our own power, even though, it's true, we are talking rather badly and indirectly. We are one step above prehistory. It's the dawn of another human organisation, a society where individual creativity gives its energy free reign, to shape the world according to each individual's dreams harmonised by all.

Utopia? Get stuffed! How condescension drivels! Who doesn't behave as if this world wasn't the dearest thing he owned? Sure, there are many who've let go, and now fall as despairingly as once they held on. Everyone wants his subjectivity to win out: we must therefore base the unity of men upon this common desire. No-one can strengthen his subjectivity without others helping him, without the aid of a group which has itself developed a subjective centre, a faithful reflection of the subjectivity of its members. The Situationist International is so far the only group to decide to defend radical subjectivity. 


\section{Chapter 22. The Space-Time of Lived Experience and the Rectification of the Past}

The dialectic of decay and supersession is the dialectic of dissociated and unitary space-time (l). The new proletariat carries within itself the realisation of childhood, which is its space-time (2). The history of separations is slowly resolved at the end of "historic" history (3). Cyclical time and linear time. - Lived space-time is space-time in transformation, and the role's space-time is that of adaptation. - The function of the past and of its projection into the future is to outlaw the present. Historical ideology is the screen that comes between the will to individual self-realisation and the will to construct history; it prevents them joining up and merging (4). The present is the space-time to be constructed; it entails the correction of the past.

1

As specialists organise the survival of the species and leave learned diagrams to programme history, the will to change life by changing the world grows among people everywhere. So much so that every single individual is confronted, like humanity as a whole, by universal despair beyond which lies oblivion or supersession. This is the age when the entire evolution of history and the particular history of the individual are tending to merge, since they are heading towards a corn destiny. the condition of a thing and its rejection. We could say that the history of the species and of myriad individual lives are gathering together to die, or together start EVERYTHING afresh. The past surges back on us with its germs of death and its seeds of life. Our childhood is also at the meeting place, and threatened with Lot's fate.

The danger overhanging childhood gives rise, I would like to believe, to the outburst of revolt against the ghastly aging to which the forced consumption of ideologies and gadgets condemns us. I want to emphasise the analogy clearly revealed between dreams and desires, and the feudal will and the subjective will of childhood. By realising childhood, won't we, adults of the technological era, rich in what children lack and strong where the greatest conquerors were weak, realise the project of the masters of old?

Can't we identify history and individual destiny more successfully than Tamerlalne or Elogabalus dared Imagine in their wildest dreams?

The primacy of life over survival Is the historical movement which will unmake history. Construct daily life and realise history. these two watchwords are now one. In decay and supersession, the essential contradiction of our era, the transition to a stage superior to prehistory is prepared. What will constitute the joint construction of life and the new society, in other words, the revolution of everyday life? Rooting out decay by superseding it. All that Is not superseded rots, all that rots incites supersession.

However far back into history, all attempts at supersession are part of the poetry of the present reversal of perspective. They are with us now, bursting the barriers of space and time and breaking 
them down. It's certain that the end of separations begins by ending the separation between space and time. What follows in the reconstitution of primordial unity must be critical analyses of the space-time of children, of unitary societies and of fragmentary societies as bearers of decay and the supersession now possible.

2

If he doesn't watch out, survival sickness soon turns a young man into a haggard old Faust, burdened with regrets, passing through the youth he longs for without realizing it. The 'teenager' bears the first wrinkles of the consumer.

Little separates him from the sixty-year-old; consuming faster and faster, he wins precocious old age to the rhythm of his compromises with inauthenticity. If he doesn't take hold of himself quickly, the past will close up behind him; he won't be able to return to what he's done, not even to remake it. So much separates him from the children he played with only yesterday. $\mathrm{He}$ has become part of the market's triviality, willing to exchange the poetry, freedom and subjective wealth of childhood for representation in the society of the spectacle. Yet nonetheless, if he seized hold of himself and awoke from the nightmare, what an enemy would . You will see him fight for the confront the forces of order' rights of his childhood with the most fearsome weapons devised by senile technocracy. We know what prodigious feats distinguished the young Simbas of the Lumumbaist revolution, in spite of their derisory equipment; so how much more can we expect from a generation that's equally pissed off but much more effectively armed, and at large in a theatre of operations that covers every aspect of daily life?

Every aspect of daily life is lived to Some extent in embryonic form during childhood. The rich hoard of events lived in a few days or a few hours prevents time passing. Two months holiday is an eternity. Two months for an old man is just a few minutes. The child's days escape adult time; their time is swollen by subjectivity, passion, dreams haunted by reality. Outside, the educators look on, waiting, watch in hand, till the child joins and fits the cycle of the hours. It's they who have time. At first, the child feels strongly the imposition of adult time as a foreign intrusion; he ends up succumbing, and agrees to grow old. Not knowing conditioning's subtle ways, he allows himself to be snared, like a young animal. When finally he possesses the weapons of criticism and wants to aim them at time, the years have carried him far from the target. In his heart his childhood lies an open wound.

So here we are all haunted by childhood, and meanwhile social organisation is scientifically destroying it. Psycho-, sociologists are on the look-out, and already the market researchers are exclaiming: "Just look at all those sweet little dollars." (Quoted by Vance Packard.) A new decimal system.

Children are playing in the street. Suddenly one of them leaves the group and comes up to me, bringing the most beautiful dreams I can remember. He shows me - for my ignorance on this point was the sole reason for my fall - what destroys the concept of age: the possibility of living many events; not just seeing them pass by, but of living them and recreating them endlessly. And now at this point where everything slips away from me and everything becomes clear to me, how could a kind of wild untamed instinct for totality not surge up in me from under so many false desires, my childishness turned dangerous through the lessons of history and class 
struggles? There cannot be a new proletariat unless it possesses in its purest form the realisation of childhood in an adult world.

We are the discoverers of a world new and yet known, which lacks the unity of space and time; a world still shot through with separations, still fragmented. The semi-barbarity of our bodies, our needs and our spontaneity (which is childhood enriched by awareness) opens to us secret passages that centuries of aristocracy never discovered, and which the bourgeoisie never even suspected. They allow us to penetrate the maze of uncompleted civilisations and all the embryonic supersessions conceived by a hidden history. Our rediscovered childhood desires rediscover the childhood of our desires. And from the savage depths of the past, always so close and as yet unfulfilled, emerges a new geography of the passions.

3

Mobile within immobility, the time of unitary societies is cyclical. People and things follow their course, moving along a circumference whose centre is God. This pivot-God, unchangeable although nowhere and everywhere, measures the duration of an eternal power. He is His own standard, and the standard of everything which, gravitating at an equal distance from Him, develops and returns without ever really flowing away or even coming unwound. "The thirteenth returns, and Is the first again."

The space of unitary societies is organised as a function of time. Both time and space belong entirely to God. Space stretches from the centre to the circumference, from heaven to earth, from the One to the multiple. At first sight, time seems irrelevant, since it neither brings God closer nor pushes Him further away. Space, on the other hand, is the path towards God: the ascending path of spiritual elevation and hierarchical promotion. Time really belongs to God alone, but the space granted men keeps a specifically human and irreducible nature. In fact, man can climb or descend, rise in society or fall, assure his salvation or. risk damnation. Space is the presence of man, the sphere of his relative freedom, while time imprisons him within its circumference. And what is the Last Judgement if not God bringing time back to Himself, the centre sucking in the circumference and gathering in its immaterial point the totality of the space imparted to His creatures? The annihilation of human matter (its occupation of space), is the project of the master who cannot totally possess his slave and therefore cannot escape being partially possessed by him.

Duration keeps a tight hand on space; it drags us towards death, eating away the space of our life. The distinction, however, doesn't appear so clearly in the course of history. Feudal societies are societies of separation just as much as bourgeois societies, since separation is caused by privative appropriation; but feudal societies have the advantage over bourgeois societies of an extraordinary strength of dissimulation.

The power of myth reunites separated elements making live unitarily though under false pretences. But the world of coherent myth is a world where the inauthentic is One, and accepted unanimously by a coherent community, be it tribe, clan or kingdom. God is the image, the symbol of the supersession of dissociated space and time, and everyone who "lives" in God takes part in this supersession. The majority can only take part in a mediated way, meaning that in the space of their daily lives, they, simple mortals, obey God, priests and leaders, the organisers of duly 
hierarchised space. In reward for submission, they are offered eternal duration, the promise of duration without space, the assurance of a pure temporality in God.

Others reckon this exchange to be a lousy deal. They have dreamt of attaining the eternal present which absolute mastery over the world confers. One is constantly struck by the analogy between the synchronised space-time of children and the will to unity of the great mystics. Thus Gregory of Palamas (1341) can describe Illumination as a sort of immaterial consciousness of unity: "The Light exists beyond space and time (...) He who shares in divine energy becomes Light himself in a sense; he is united with the Light and, with Light, he sees with perfect consciousness all that remains hidden to those who have not received this grace." This confused hope, which could only be Indistinct and even indescribable, was popularised and made more specific by the transient bourgeois era. It concretised it by killing off the aristocracy with its spirituality, and gave it a chance by taking its own decomposition to its logical conclusion. The history of separations is slowly resolved in the end of separations. The feudal unitary illusion is gradually embodied in the libertarian unity of the life to be constructed, which lies beyond materially guaranteed survival.

4

Einstein's speculations on space and time remind us how dead God is. When myth could no longer contain the dissociation of space and time, the malaise to which consciousness was then subject made Romanticism's heyday (viz. The attraction of far-off lands, anguish at time's slipping away...)

How does the bourgeois mind conceive of time? No longer as God's time, but rather as the time of power, fragmented power. Time in shreds has a common measurement in the moment, which attempts to recall cyclical time. The circumference no longer exists; instead we have a finite and infinite straight line. In place of everyone's synchronous regulation according to hours fixed by God, there are succeeding states in which everyone is chasing after himself but never catching up, as if the curse of Becoming damned us to getting only a glimpse of the back while the human face remains unknown and inaccessible, forever turned towards the future. If there is no longer a circular space under the all-seeing central eye of the Almighty, there is a series of little points which appear autonomous but are in reality being integrated in a ripple of succession along the line they trace as each one joins on to the next.

Time flowed through the Mediaeval hourglass, but it was the same sand which flowed back and forth from one globe to the other. On the circular clock-face, time sheds its seeds and never returns. An irony of forms: the new spirit took its form from a dead reality, while the bourgeoisie is wearing the death of time, specifically the death of its time, in its wrist-watches as in the cheap finery of its humanist woolgathering, both of which appear cyclical.

But nothing's made of it, so here we are in the age of watchmakers. The economic imperative has converted man into a living chronometer, distinguishing feature on his wrist. This is the time of work, progress and output, production, consumption and programming; it's time for the spectacle, for a kiss, or a photo, time for anything (time is money). The time-commodity. Survival time.

Space is a point on the line of time, in the machine transforming the future into the past. Time controls lived space, but controls it externally, making it pass through, in transit. But the space 
of individual life isn't pure space, nor is the time it sweeps along pure temporality. This is worth examining in greater depth.

Each point terminating the line of time is unique and particular, but as soon as the next point is added it is drowned in the uniform line, swallowed up by a past with other pasts in its stomach. It is impossible to distinguish them. Thus each point adds to the line that makes it disappear.

Power ensures its duration on the model of destruction and replacement, but at the same time those who are encouraged to consume power destroy and renew it by enduring. If power destroys everything, it destroys itself; and if it doesn't destroy anything, it is destroyed. Only between the two poles of this contradiction is there duration, and the dictatorship of the consumable brings them closer every day. And its duration is subordinated to the simple duration of men, or, in other words, to the permanence of their survival. This is why the problem of dissociated space-time is posed today in revolutionary terms.

Lived space may well be a universe of dreams and desires and prodigious creatlvlty, but in the order of duration it is only one point succeeding another; it flows on a precise duration towards its destruction. It appears, grows and disappears in the anonymous line of the past where its corpse offers food for historians and sudden jolts of memory.

The advantage of the lived point of space is that it partly escapes the generalised system of conditioning; its disadvantag is that it is nothing in itself. The space of daily life diverts a little time to its own ends, it imprisons it and makes it its own. On the other hand, time that flows away soaks into lived space and interiorises the sense of transitoriness, of destructIon and death. Let me explain.

The punctual space of daily life steals a part of "exterior" time, thanks to which it creates a restricted unitary space-time: it is the space-time of moments, of creativity, pleasure and orgasm. The area of this alchemy is minute, but its lived intensity is such that it exercises an unequaled fascination on most people. In the eyes of power, which observe from outside, the passionate moment is a quite insignificant point, an instant drained from the future into the past. The line of objective time knows nothing and wishes to know nothing of the present as immediate subjective presence. And, in its turn, subjective life concentrated in the space of a point - my joy, my pleasure, my daydreams - isn't interested in time that flows away, in linear time, the time of things. On the contrary, it wants to learn everything about its present - for, after all, it is only a present.

Thus, lived space extracts, from the time sweeping it away, a part with which it creates its present, or rather attempts to for the present has always to be constructed.

It is the unitary space-time of love and poetry, of pleasure and communication... It is lived experience without dead time. On the other hand, linear time, objective time, time that flows away, infuses in its turn the space imparted to everyday life. It is introduced as negative time, as dead time, a reflection of the time of destruction. It is the time of the role, the time within life itself which encourages it to lose its character and renounce authentically lived space, to hold back and prefer appearances and the spectacular function. The space-time created by this hybrid marriage is merely the space-time of survival.

What Is private life? It is, in any instant, on any point drawn towards its destruction along the line of survival, the amalgam of a real space-time (the moment) and a fake (the role). Obviously, the structure of private life doesn't strictly conform to such a dichotomy. There is permanent interaction. Thus the restrictions that beset lived experience on every side, and compress it into far too small a space, incite it to change itself into a role, to enter the time that flows away 
as a commodity, become purely repetitious, and create, as accelerated time, the fictitious space of appearances. While at the same time the malaise born of inauthenticity, space falsely lived, sends one back to search for real time, subjectivity's time, which is the present. So private life is dialectically a real lived time + a fictitious spectacular time + a fictitious spectacular space + a real lived space.

The more fictitious time compounds with the fictitious space it creates, the further one is heading towards the state of being a thing and towards pure exchange value. The more the space of authentic lived experience compounds with really lived time, the stronger the mastery of man becomes.

Unitarily lived space-time is the guerilla's first base, the qualitative spark in the night that's still concealing the revolution of daily life.

Thus, not only does objective time furiously try to destroy punctual space by hurling it into the past, but moreover it gnaws away at it from inside by introducing this accelerated rhythm which creates the substance of the role.

(The role's fictitious space in effect results from the rapid repetition of an attitude, just as the repetition of a film image makes it seem to live.) The role installs the time that flows away, aging and death within subjective consciousness. This is the "rut into which consciousness has been forced" which Antonin Artaud talks about. Dominated from outside by linear time and from inside by the role's time, subjectivity has nothing else to do than become a thing, a valuable commodity. What's more, the process speeds up through history. In fact, the role is henceforward a consumption of time in a society where the time of consumption is the only one acknowledged. And once again the unity of oppression creates the unity of opposition. What is death today? Absence of subjectivity and absence of the present.

The will to live always reacts unitarily. Most individuals really divert time to the advantage of lived space. If their efforts to intensify lived experience and increase the space-time of authenticity don't get lost in confusion or break up in isolation, then perhaps objective time, the time of death, can be smashed. Isn't the revolutionary moment an eternal youth?

The project of enriching the space-time of lived experience must analyse what impoverishes it. Linear time only has a hold over men to the extent that it forbids them to transform the world, and forces them to adapt to it. Freely radiating creativity is power's public enemy number one.

And the strength of creativity lies in the unitary. How does power try to break the unity of lived space-time? By transforming lived experience into a commodity and throwing it on the market of the spectacle at the mercy of the supply and demand of roles and stereotypes. I examined this in the section devoted to the role (Chapter XV). Also, by recourse to a particular means of identification: the joint attraction of the past and future, which annihilates the present. And, finally, by trying to recuperate within an Ideology of history the will to construct the unitary space-time of lived experience (in other words, the will to create situations worth living). I will examine these two last points further.

From the viewpoint of power, there are no lived moments (lived experience has no name), only instants succeeding one another and all equal in the line of the past. A whole system of 
conditioning broadcasts this attitude, hidden persuasion introjects it. And here's the result. Just where is this present that people go on about? In what forgotten corner of everyday life does it skulk?

If we're not looking on, we're looking forward or looking back. The shade of my next meeting joins up with the shade of my last one. Both haunt me. Every passing second drags me from the moment that was to the moment that will be. Every second spirits me away from myself; now never exists. A meaningless commotion makes sure that everyone is "just passing through", or as we say so prettily, "just passing the tlme", and even ensures that time passes into man, through and through. When Schopenhauer writes: "Before Kant, we were in time ; since Kant, time is in us", he well expresses how aging and decrepitude permeate men's consciousness. But it never occurs to Schopenhauer that man's being torn to pieces on the rack of time reduced to the apparent difference between future and past is exactly what's pushing him, as a philosopher, to build up his mystique of despair.

Imagine the despair and giddiness of someone torn between two instants which he is pursuing in zigzags, never catching them up nor laying hold of himself. Or the despair of passionate expectation: you are caught in the spell of some past moment, love, for Instance, the woman you love is about to appear, you're sure of it, you already feel her kisses... Passionate expectation is no more than the shadow of the situation to be constructed. But one must admit that most of the time the whirligig of memory and anticipation gets in the way of expectation and the feeling of the present, and instead starts up a mad run of dead and empty time.

Through power's telescope, the future is just the past rehashed. A dollop of known inauthenticity is pushed forward by so-called hopeful imagination into the time it is already filling up with utter vacuity. One's only memories are of roles once played, and one's only future an eternal remake. According to power, men's memory should only operate within its time-scale, as a constant reminder of its presence. A nihil novi sub sole, popularly expressed as "someone must always be in charge".

The future advertised as "other time" is a worthy response to the other space where I'm supposed to let myself relax. Change time, change skin, change the hour. change the role; only alienation doesn't change. Every time that I is another, I'm hovering somewhere between past and future. Roles never have a present. How could one wish a role good morning? If I bungle my present - here being always elsewhere - could I expect to find myself with a pleasant past and future?

The crowning achievement of the identification with the past-future is historical ideology, which causes individual and collective will to develop on its head.

Time is one form of mental perception, clearly not one of man's inventions but a dialectical relationship with outside reality; it is therefore a tributary connection stemming from alienation and man's struggle against it. Animals submit absolutely to adaptation and are unaware of time. Man rejects adaptation and attempts to transform the world. Every time he slips up in his desire to be demiurge, he suffers the agony of having to adapt, the wrenching pain when he feels reduced to the animal's passivity. Awareness of necessary adaptation is awareness of time slipping away, which is why time is so intimately tied up with human suffering. The more his need to adapt to circumstances overrides the desire and possibility of changing them, the more awareness of time 
grabs him by the throat. What else is survival sickness except the acute awareness of that other time and space slipping away, the awareness of alienation? Rejecting the awareness of aging and the objective conditions of aging awareness entails a much greater urgency on the part of the will to remake history, with more consequence and according to the wishes of everyone's subjectivity.

The sole reason for an historical ideology is to prevent men making history themselves. How better to distract men away from their present than by attracting them to where time flows away? This is the historian's role. He organises the past, by breaking it up according to the official line of time, then classifies events according to ad hoc categories. These easy-to-use classifications place the event in quarantine. Unshakable parentheses isolate and contain it, stop it coming to life, being reborn and breaking out again in the streets of our daily 1ife. The event is frozen. One is forbidden to rejoin it, remake it, perfect it, lead it on towards its supersession. It is just there, for all eternity suspended for the appreciation of aesthetes. Slightly alter its signification, and, hey presto! it can be transposed straight into the future, which is just the historians repeating themselves. The future they foretell is a collage of their memories. Vulgarised by Stalinist thinkers, the famous concept of the Sense of History has ended up leaving the future as drained of humanity as the past.

Encouraged to identify himself with some other time and some other person, today's individual has managed to have his present stolen from him under the illusion of gaining a historical perspective. In a spectacular space-time ("You are entering history, comrades.") he loses the taste of authentic life. Yet, those who refuse the heroism of historical action are warped by the complementary mystification that the psychological sector bestows on them. These two categories rub shoulders, and fuse in the extreme poverty of recuperation. You choose: either history or a nice quiet life.

All roles are decaying, whether historical or not. The crisis of history and the crisis of daily life coincide. The mixture will be explosive. From now on we must divert history to subjective ends; and with everyone's help. Marx really wished for nothing less.

\section{5}

For nearly a century, significant pictural movements have been playing about - even joking - with space. Nothing could express so well the restless and passionate search for a new space to inhabit as artistic creativity. And humour is surely the best way to express the feeling that art could no longer provide a valid solution. I'm thinking of the beginnings of Impressionism, Pointillism, Fauvism, Cubism, the Dada collages, and the first abstracts.

As art has decomposed, the number of people affected by the malaise which was first of all felt by the artist has grown. Today, the desire to construct an art of living has reached the level of a popular demand. The researches of a whole artistic past, which really have been so carelessly abandoned, must be incorporated in a passionately lived space-time.

What I'm thinking of here are memories of mortal wounds. If you're not busy being born you're busy rotting. The past is now irretrievable, and the final twist of irony is that those who discuss it as if it were definite fact are actually grinding it away, falsifying and arranging it as fashion dictates. It's very reminiscent of poor Wilson in Orwell's 1984 rewriting old official news items which had been contradicted by a subsequent turn of events. 
There's only one allowable way to forget, which is to wipe out the past by realising it. Avert decomposition by supersession. However time-honoured, facts never have the last word. A radical change in the present is enough to make them topple off their pedestals and fall at our feet. I know no more touching example of the correction of the past than the one given by Victor Serge in Ville Conquise; and I've no need to know a better one.

At the end of a lecture on the Paris Commune, given during the height of the Bolshevik revolution, a soldier at the back of the room lumbered up out of his armchair. "You could easily hear his commanding rumble: 'Tell the story of Dr Millière's execution.' Standing up, a giant of a man, with his head bowed so that all you could see of his face were his large hairy jowls, sullen mouth and buckled wrinkled brows - he looked like one of those busts of Beethoven - he listened to the story: Dr Millière, in a dark blue overcoat and top hat, driven in the rain through the Paris streets, - forced to kneel on the steps of the Panthéon, - shouting 'Long live humanity!' - the words of the Versailles sentry leaning on the railings a few yards away: 'We'll fuck you with your humanity!' In the black night of the unlit street the peasant came up to the lecturer (...) His taciturn manner was gone. He had a secret he wanted to share. 'I was also in Perm's government, last year when the Kulaks revolted (...) On the way I'd read Arnould's pamphlet Les Morts de la Commune.. It's a fine pamphlet. I was thinking about Millière. I've avenged him, citizen! It was one of the best days of my life, and I haven't had many of them. Point for point I've avenged him. Like that on the steps of the church, I shot the biggest landowner in the district; I've forgotten his name and I couldn't care less...' After a short silence, he added - 'But it was me who shouted 'Long live humanity!'”

Past revolts take on a new dimension in my present, that of an immanent reality to be constructed immediately. The walks of the Luxembourg palace and the square of the Tour Saintjacques still echo the shots and the cries of the suppressed Commune. But there will be more shots fired and more heaps of corpses. One day the revolutionaries of all the ages will join together with the revolutionaries of all countries to wash the wall of the Fédérés with the blood of firing squads.

To construct the present is to correct the past, change the psycho-geography of the landscape, free dreams and unsatisfied desires from their matrix, and bring all the separate passions together in harmony. From the insurgents of 1525 to the Mulétist rebels, Spartacus to Pancho Villa, Lucretius to Lautréamont, there's only the time of my will to live.

Hope for tomorrow overshadows our festivities. The future is worse than the Ocean - it contains nothing. Blue-print, program, long-term view... count your chickens before you've even seen eggs. But if you construct the present well the future will be more than abundant.

Only the quick of the present, its multiplicity, interests me. Despite all that might prevent me, I want to surround myself with today as with a great light; and bring that other time and the space of other people to the immediacy of everyday experience. I wish to embody Schwester Katrei's formulation: "Everything that is in me is also outside me and everywhere, around me; everything belongs to me, and everywhere I can see only what lies within me." That's no more than subjectivity's rightful triumph, as far as history allows it today; however firmly we go about tearing down the bastilles of the future and however thorough our restructuring of the past, if only we could live each second as if caught in the spell of eternal recurrence, it would exactly and endlessly repeat itself.

Only the present can be total. A point of incredible density. We must learn to slow down time and live the permanent passion of immediate experience. A tennis champion tells the story 
how once during a very tense match a ball was played that was very difficult to take. Suddenly, he saw it approach slowed down, so slowly that he had time to judge the situation, make a reasonable decision and return it with masterful brilliance. In the space of creation, time dilates. In inauthenticity, it speeds up. Whoever possesses the poetry of the present will experience the same adventure as the little Chinese boy who loved the Queen of the sea. He went to look for her at the bottom of the ocean. When he returned to the land he met an old man cutting roses who said to him: "My grandfather told me of a young boy who disappeared in the sea, and who had exactly the same name as you."

"Punctuality garners time" runs the esoteric tradition. Passed through the developing tray of history, the phrase of the Pistis Sophia - "One day of light is a million years in the world" is exactly Lenin's remark that some revolutionary days are worth centuries.

It is always a matter of resolving the contradictions of the present, not stopping half way and getting 'distracted', but going straight for supersession. Collective work, the work of passion, the work of poetry and the work of the game (Eternity is the world of the game, said Boehme). However poor it may be, the present always contains true wealth, the wealth of possible creation. But now you know well enough - you live well enough - all the things that tear out of my grasp this uninterrupted poem that is my joy.

Yield to the vortex of dead time, to age and decay till body and mind are empty? Rather disappear in defiance of duration. In his Précis de l'histoire universelle which appeared in Paris in year VII of the Republic, citizen Anquetil tells of a Persian prince who, wounded by the vanity of the world, withdrew to a chateau with forty of the most beautiful and intelligent courtisans of the kingdom. He died within a month, worn out by too much pleasure. But what is death compared with this eternity? If I have to die, at least let it be as I have loved. 


\section{Chapter 23. The Unitary Triad: Self-Rrealisation, Communication and Participation}

The repressive unity of power is threefold: coercion, seduction and mediation. This is no more than the inversion and perversion of an equally threefold unitary project. The new society, as it develops underground, chaotically, is moving towards a total honesty - a transparency - between individuals: an honesty promoting the participation of each individual in the self-realisation of everyone else. Creativity, love and play stand in the same relation to true life as the need to eat and the need to find shelter stand in relation to survival (1). Attempts to realise oneself can only be based on creativity (2). Attempts to communicate can only be based on love (4). Attempts to participate can only be based on play (6). Separated from one another these three projects merely strengthen the repressive unity of power. Radical subjectivity is the presence - which can be seen in almost everyone - of the same desire to create a truly passionate life (3). The erotic is the spontaneous coherence fusing attempts to enrich lived experience (5).

1

The construction of everyday life fuses reason and passion. The plain confusion to which life has always been subject comes from the mystification covering up the utter triviality of merely continuing to exist. Will to live entails practical organisation. Individual desire for a rich multidimensional life cannot be totally divorced from a collective project. The oppression exercised by human government is essentially threefold: coercion, alienating mediation and magical seduction. The will to live also draws its vitality and its coherence from the unity of a threefold project: self-realisation, communication and participation.

If human history was neither reduced to, nor dissociated from, the history of human survival, the dialectic of this threefold project (in conjunction with the dialectic of the productive forces) would prove sufficient explanation for most things men have done to themselves and to one another. Every riot, every revolution, reveals a passionate quest for exuberant life, for total honesty between people, for a collective form of transformation of the world. Today, one can see, throughout the whole of history, three fundamental passions related to life in the same way that the need to eat and find shelter are related to survival. The desire to create, the desire to love and the desire to play interact with the need to eat and find shelter, just as the will to live never ceases to play havoc with the necessity of surviving. Obviously, the importance of the part played by each element changes from one time to another, but today their whole importance lies in the extent to which they can be unified.

Today, with the Welfare State, the question of survival has become only a part of the whole problem of life. As we hope to have shown. Life-economy has gradually absorbed survival- 
economy, and in this context the dissociation of the three projects, and of the passions underlying them, appears more and more clearly as a consequence of a fundamentally erroneous distinction between life and survival. However, since the whole of existence is torn between two perspectives - that of separation, of power; and that of revolution, of unity - and is therefore essentially ambiguous, I am forced to discuss each project at once separately and together.

The project of self-realisation is born of the passion of creativity, in the moment when subjectivity wells up and wants to reign universally. The project of communication is born of the passion of love, whenever people discover in one another the selfsame will to conquest. The project of participation is born of the passion of playing, whenever group activity facilitates the self-realisation of each individual.

Isolated, the three passions become perverted. Dissociated, the three projects become falsified. The will to self-realisation is turned into the will to power; sacrificed to status and role-playing, it reigns in a world of restrictions and illusions. The will to communication becomes objective dishonesty; based on relationships between objects, it provides the field of operations for semiology, the science of fucked-up communications. The will to participation organises the loneliness of everyone in the lonely crowd; it creates the tyranny of the illusory community.

Isolated, each passion is integrated in a metaphysical vision which makes it absolute and, as such, leaves it completely out of touch. Intellectuals can be funny when they try: they pull the plug out and then announce that the electricity doesn't work. Not in the least abashed they proceed to inform us that we're really in the dark, and that's just all there is to it. Wherever everything is separated from everything else, everything really is impossible. Cartesian analysis can only produce the jerry-built. The armies of Order can recruit only the crippled.

\section{The Project of Self-Realisation}

Assurance of security leaves unused a large supply of energy formerly expended in the struggle for survival. The will to power tries to recuperate, for the reinforcement of hierarchical slavery, this freefloating energy which could be used for the blossoming of individual life (l). Universal oppression forces almost everyone to withdraw strategically towards what they feel to be their only uncontaminated possession: their subjectivity. The revolution of everyday life must create practical forms for the countless attacks on the outside world launched daily by subjectivity (2).

\section{(a)}

The historic phase of privative appropriation stopped man being the demiurge he was forced to create in an ideal form and thus to confirm his own real failure. At heart everyone wants to be God. To date we have merely prevented ourselves being so. I have shown how hierarchical social organisation builds up the world by breaking men down; how the perfection of its structure and machinery makes it function like a giant computer whose programmers are also programmed; how, lastly, the cybernetic state is the coldest of all cold monsters.

In these conditions, the struggle for enough to eat, for comfort, for stable employment and for security are, on the social front, so many aggressive raids which slowly but surely are becoming rearguard actions, despite their very real importance. The struggle for survival took up and 
still takes up an amount of energy and creativity which revolutionary society will inherit like a pack of ravening wolves. Despite false conflicts and illusory activities, a constantly stimulated creative energy is no longer being absorbed fast enough by consumer society. What will happen to this vitality suddenly at a loose end, to this surplus virility which neither coercion nor lies can really continue to handle? No longer recuperated by artistic and cultural consumption - by the ideological spectacle - creativity will turn spontaneously against the very safeguards of survival itself.

Rebels have only their survival to lose. And there are only two ways in which they can lose it: either by living or by dying. And since survival is no more than dying very slowly, there is a temptation containing a very great deal of genuine feeling, to speed the whole thing up and to die a damn sight faster. To 'live' negatively the negation of survival. Or, on the other hand, to try to survive as an anti-survivor, focusing all one's energy on breaking through to real life. To make survival no more than the basis of a systematic quest for happiness.

Self-realisation is impossible in this world. Half demented rebellion remains, for all its ferocity, a prisoner of the authoritarian dilemma: survival or death. This half-rebellion, this savage creativity so easily broken in by the order of things, is the will to power.

The will to power is the project of self-realization falsified - divorced from any attempt to communicate with, or to participate in, the life of others. It is the passion of creating and of creating oneself caught in the hierarchical system, condemned to turn the treadmill of repression and appearances. Accepting being put down because you can put others down in your turn. The hero is he who sacrifices himself to the power of his role and his rifle. And when, finally, he's burnt out, he follows Voltaire's advice and cultivates his garden. Meantime his mediocrity has become a model for the common rule of mortals.

The hero, the ruler, the superstar, the millionaire, the expert... How many times have they sold out all they held most dear? How many sacrifices have they made to force a few people, or a few million people, people they quite rightly regard as complete idiots, to have their photograph on the wall, to have their name remembered, to be stared at in the street?

Yet, for all its bullshit, the will to power does contain traces of an authentic will to live. Think of the virtú of the condottiere, of the Titans of the Renaissance. But the condottiere are dead and buried. All that's left is industrial magnates, gangsters and hired guns, dealers in art and artillery. The adventurer and the explorer are comic-strip characters (Tin-tin and Schweitzer). And it's with these people that Zarathustra dreamt of peopling the heights of Sils-Maria; it's in these abortions he thought he could see the lineaments of a future race. Nietzsche is, in fact, the last master, crucified by his own illusions. His death was a replay, with more brio, and in slightly better taste, of the black comedy of Golgotha. It explains the disappearance of the feudal lords just as the death of Christ explained the disappearance of God. Nietzsche may have had a refined sensibility but the stench of Christianity didn't stop him breathing it in by the lungful. And he pretends not to understand that Christianity, however much contempt it may have poured on the will to power, is in fact its best means of protection, its most faithful bodyguard, since it stands in the way of the appearance of masters who no longer need slaves to be masters. Nietzsche blessed a world in which the will to live is condemned never to be more than the will to power. His last letters were signed 'Dionysus the Crucified'. He too was looking for someone to assume responsibility for his broken zest. You don't mess with the witch-doctor of Bethlehem. 
Nazism is Nietzschean logic called to order by history. The question was: what can become of those who wish to live like a lord in a society from which all true rulers have disappeared? And the answer: a super-slave. Nietzsche's concept of the superman, however threadbare it may have been, is worlds apart from what we know of the domestics who ran the Third Reich. Fascism knows only one superman: the State.

The State superman is the strength of the weak. This is why the desires of an isolated individual can always fit I ' $n$ with a role played impeccably in the official spectacle. The will to power is an exhibitionistic will. The isolated individual detests other people, feels contempt for the masses of which he is a perfect specimen himself. He is, in fact, the most contemptible man of all. Showing off, amidst the crassest sort of illusory community, is his 'dynamism'; the rat-race, his 'love of danger'.

The manager, the leader, the tough guy, the mobster know little joy. Ability to endure is their main qualification. Their morale is that of pioneers, of spies, of scouts, of the shock-troops of conformity. "NO animal would have done what I have done..." What is the gangster-trip? A will to appear since one cannot be; a way of escaping the emptiness of one's own existence by running greater and greater risks. But only servants are proud of their sacrifices. Here the part rules the whole: sometimes the artificial being of the role, sometimes the directness of the animal. And the animal does what the man cannot do. The heroes who march past, colours flying, the Red Army, the S.S., the U.S. marines, these are the same people who burnt and cut living flesh at Budapest, at Warsaw, at Algiers. Army discipline is based on the uptightness of the rank and file. Cops know when to snarl and when to fawn.

The will to power is a compensation for slavery. At the same time it is a hatred of slavery. The most striking 'personalities' of the past never identified themselves with a Cause. They just used Causes to further their own personal hunger for power. But as great Causes began to break up and disappear, so did the ambitious individuals concerned. However, the game goes on. People rely on Causes because they haven't been able to make their own life a Cause sufficient unto itself. Through the Cause and the sacrifice it entails they stagger along, backwards, trying to find their own will to live.

Sometimes desire for freedom and for play breaks out among law and order's conscripts. I am thinking of Salvatore Giuliano, before he was recuperated by the landowners, of Billy the Kid, of various gangsters momentarily close to the anarchist terrorists. Legionnaires and mercenaries have defected to the side of Algerian or Congolese rebels, thus choosing the party of open insurrection and taking their desire to play to its logical conclusion: blowing their whole scene sky-high, and jumping into the dark.

I also have teenage gangs in mind. The very childishness of their will to power has often kept their will to live almost uncontaminated. Obviously the delinquent is threatened with recuperation. Firstly, as a consumer, because he wants things he cannot afford to buy; then, as he gets older, as a producer. But, within the gang, playing remains of such great importance that truly revolutionary consciousness can never be far away. If the violence inherent in teenage gangs stopped squandering itself in exhibitionistic and generally half-baked brawls and rave-ups and only saw how much real poetry was to be found in a riot, then their gameplaying, as it became increasingly riotous, would almost certainly set off a chain reaction: a qualitative flash. Almost everyone is fed up with their life. Almost everyone is sick of being pushed around. Almost everyone is sick of the lies they come out with all day long. All that is needed is a spark - plus tactics. Should delinquents arrive at revolutionary consciousness simply through understanding what 
they already are, and by wanting to be more so, then it's quite possible that they could prove the key-factor in a general social retake on reality. This could be vitally important. Actually, all that's really necessary is the federation of their gangs.

(b)

So far the heart of life has been sought anywhere but in the heart of man. Creativity has always been pushed to one side. It has been suburban; and, in fact, urbanism reflects very accurately the misadventures of the axis around which life has been organised for thousands of years. The first cities grew up around a stronghold or sacred spot, a temple or a church, a point where heaven and earth converged. Industrial towns, with their mean, dark streets surround a factory or industrial plant; administrative centres preside over empty rectilinear avenues. Finally, the most recent examples of town-planning simply have no centre at all. It's becoming increasingly obvious: the reference point they propose is always somewhere else. These are labyrinths in which you are allowed only to lose yourself. No games, No meetings. No living. A desert of plate-glass. A grid of roads. High-rise apartment blocks.

Oppression is no longer centralised because oppression is everywhere. The positive aspects of this: everyone begins to see, in conditions of almost total isolation, that first and foremost it is themselves that they have to save, themselves that they have to choose as the centre, their own subjectivity out of which they have to build a world that everyone else will recognise as their native land.

One can only rediscover other people by consciously rediscovering oneself. For as long as individual creativity is not at the centre of social life, man's only freedom will be freedom to destroy and be destroyed. If you do other people's thinking for them, they will do your thinking for you. And he who thinks for you judges you, he reduces you to his own norm and, whatever his intentions may be, he will end by making you stupid - for stupidity doesn't come from a lack of intelligence, as stupid people imagine it does, it comes from renouncing, from abandoning one's own true self. So if anyone asks you what you are doing, asks you to explain yourself, treat him as a judge - that is to say, as an enemy.

"I want someone to succeed me; I want children; I want disciples; I want a father; I don't want myself". A few words from those high on Christianity, whether the Roman or the Peking brand. Only unhappiness and neurosis can follow. My subjectivity is too important for me to take my lack of inhibition to the point of either asking other people for their help or of refusing it when it is offered. The point is neither to lose oneself in oneself nor to lose oneself in other people. Anyone who realises that his problems are ultimately social in nature must first of all find himself. Otherwise he will find nothing in other people apart from his own absence.

Nothing is more difficult, or more painful, to approach than the question of one's own selfregeneration. In the heart of each human being there is a hidden room, a camera obscura, to which only the mind and dreams can find the door. A magic circle in which the world and the self are reconciled where every childish wish comes true. The passions flower there, brilliant, poisonous blossoms clinging to and thriving on air, thin air. I create a universe for myself and, like some fantastic tyrannical God, people it with beings who will never live for anyone else. One of my favourite James Thurber stories is the one where Walter Mitty dreams that he is a swashbuckling captain, then an eminent surgeon, then a coldblooded killer and finally a war hero. All this as he drove his old Buick downtown to buy some dog biscuits. 
The real importance of subjectivity can easily be measured by the general embarassment with which it is approached. Everyone wants to pass it off as their mind 'wandering', as 'introversion', as 'being stoned'. Everyone censors their own daydreams. But isn't it the phantoms and visions of the mind that have dealt the most deadly blows at morality, authority, language and our collective hypnotic sleep? Isn't a fertile imagination the source of all creativity, the alembic distilling the quick of life: the bridgehead driven into the old world and across which the coming invasions will pour?

Anyone who can be open-minded about their interior life will begin to see a different world outside themselves values change, things lose their glamour and become plain instruments. In the magic of the imaginary, things exist only to be picked up and toyed with, caressed, broken apart and put together again in any way one sees fit. Once the prime importance of subjectivity is accepted the spell cast upon things is broken. Starting from other people, one's self-pursuit is fruitless, one repeats the same futile gestures time after time. Starting from oneself, on the contrary, gestures are not repeated but taken back into oneself, corrected and realised in a more highly evolved form.

Daydreaming could become the most powerful dynamo in the world. Modern technological expertise, just as it makes everything considered 'Utopian' in the past a purely practical undertaking today, also does away with the purely fairytale nature of dreams. All my wishes can come true from the moment that modern technology is put to their service.

And even deprived of these techniques, can subjectivity ever stray far from the truth? it is possible for me to objectify all that I have dreamt of being. Everyone, at least once in his life has pulled off the same sort of thing as Lassailly or Nechaev; Lassailly, passing himself off as the author of an unwritten book, ends up by becoming a real writer, author of the Roueries de Trialph; Nechaev, touching Bakunin for money in the name of a nonexistent terrorist organisation, finally does get a real group of nihilists going. One day I must be as I have wanted to seem; the particular spectacular role I have so long wanted to be will become genuine. Thus subjectivity subverts roles and spectacular lies to its own ends: it reinvests appearances in reality.

Subjective imagination is not purely spiritual: it is always seeking its practical realisation. There can be no doubt that the artistic spectacle - above all, in its narrative forms - plays on subjectivity's quest for its own self-realisation, but solely by captivating it, by making it function in terms of passive identification. Debord's agitational film Critique de la séparation stresses the point: "Normally, the things that happen to us, things which really do involve us and demand our attention, leave us no more than bored and distant spectators. However, almost any situation, once it has been transposed artistically, awakens our attention: we want to take part in it, to change it. This paradox must be turned upside down - put back on its feet." The forces of the artistic spectacle must be dissolved and their equipment pass into the arsenal of individual dreams. Once armed in this way, there will no longer be any question of treating them as phantasies. This is the only way in which the problem of making art real can be seen.

\section{Radical Subjectivity}

Each subjectivity is different from every other one, but all obey the same wilt to self-realisation. The problem is one of setting their variety in a common direction, of creating a united front of subjectivity. Any attempt to build a new life is subject to two conditions: first, that the realisation of 
each individual subjectivity will either take place in a collective form or it will not take place at all; and, secondly, that "To tell the truth, the only reason anyone fights is for what they love. Fighting for everyone else is only the consequence." (Saint-fust)

My subjectivity feeds on events. The most varied events: a riot, a sexual fiasco, a meeting, a memory, a rotten tooth. Reality, as it evolves, sweeps me with it. I'm struck by everything and, though not everything strikes me in the same way, I am always struck by the same basic contradiction: although I can always see how beautiful anything could be if only I could change it, in practically every case there is nothing I can really do. Everything is changed into something else in my imagination, then the dead weight of things changes it back into what it was in the first place. A bridge between imagination and reality must be built. Only a truly radical perspective can give everyone the right to make anything out of anything. A radical perspective grasps men by their roots and the roots of men lie in their subjectivity - this unique zone they possess in common.

You can't make it on your own. You can't live your own life to the full in isolation. But can any individual - any individual who has got anything at all straight about himself and the world fail to see a will identical to his own among everyone he knows: the same journey leaving from the same place?

All forms of hierarchical power differ from one another and yet all betray a fundamental identity in their oppressive nature. In the same way, all subjectivities are different from one another and yet all reveal a fundamental identity in their will to total self-realisation. Only because of this can one speak of a real "radical subjectivity".

There is a common root to every subjectivity, though all are unique and irreducible: the will to realise oneself by transforming the world, the will to live every sensation, every experience, every possibility to the full. This can be seen in everyone, at different stages of consciousness and determination. Its real power depends on the degree of collective unity it can attain without losing its variety. Consciousness of this necessary unity comes from what one could call a reflex of identity - the diametrically opposite movement to that of identification. Through identification we lose our uniqueness in the variety of roles; through the reflex of identity we strengthen our wealth of individual possibilities in the unity of federated subjectivities.

Radical subjectivity can only be based on the reflex of identlty. One's own quest searches for itself everywhere in others. "While I was on a mission in the state of Tchou", says Confucius, "I saw some piglets suckling their dead mother. After a short while they shuddered and went away. They had sensed that she could no longer see them and that she wasn't like them any more. What they loved in their mother wasn't her body, but whatever it was that made her body live." Likewise, what I am looking for in other people is the richest part of myself hidden within them. Can the reflex of identity spread naturally? One can only hope so. Certainly it's high time for it.

No one has ever questioned the interest men take in being fed, sheltered, cared for, protected from hardship and disaster. The imperfections of technology - transformed at a very early date into social imperfections - have postponed the satisfaction of this universal desire. Today, planned economy allows one to foresee the final solution of the problems of survival. Now that the needs of survival are well on the way to being satisfied, at least in the hyper-industrialised countries, it is becoming painfully obvious, to say the least of it, that there are also human passions which must be satisfied, that the satisfaction of these passions is of vital importance to everyone and, furthermore, that failure to do so will undermine, if not destroy, all our acquisitions in terms of material survival. As the problems of survival are slowly but surely resolved 
they begin to clash more and more brutally with the problems of life which have been, just as slowly and just as surely, sacrificed to the needs of survival. The chickens are all coming home to roost: henceforward, socialist-type planning is opposed to the true harmonisation of life in common.

Radical subjectivity is the common front of rediscovered identity. Those who can't see themselves in other people are condemned for ever to be strangers to themselves. I can't do anything for other people if they can't do anything for themselves. It's along these lines that concepts such as those of 'cognition' and 're-cognition', of 'sympathy' and 'sympathising', should be reexamined.

Cognition is only of value if it leads to the re-cognition of a common project - to the reflex of identity. To realise radical imagination requires a varied knowledge, but this knowledge is nothing without the style with which it is handled. As the first years of the S.I. have shown, the worst crises within a coherent revolutionary group are caused by those closest by their knowledge and furthest away by their lived experience and by the importance they place upon it. Likewise, 'partisans'. They both identify themselves with the group and get in its way. They understand everything except what is really at stake. They demand knowledge because they are incapable of demanding themselves.

By seizing myself, I break other people's hold over me. Thus I let them see themselves in me. No one can evolve freely without spreading freedom in the world.

"I want to be myself. I want to walk without impediment. I want to affirm myself alone in my freedom. May everyone do likewise. Don't worry any more about the fate of the revolution - it will be safer in the hands of everyone than in the hands of political parties." So said Coeurderoy. I agree one hundred per cent. Nothing authorises me to speak in the name of other people. I am only my own delegate. Yet at the same time I can't help thinking that my life isn't solely my own concern but that I serve the interests of thousands of other people by living the way I live, and by struggling to live more intensely and more freely. My friends and I are one, and we know it. Each of us is acting for each other by acting for himself. Honesty is our only hope.

\section{The Project of Communication}

Love offers the purest glimpse of true communication that any of us have had. But, as communication in general tends to break down more and more, the existence of love becomes increasingly precarious. It is threatened on every side. Everything tends to reduce lovers to objects; real meetings are replaced by mechanical sex: by the posturing of countless Playboys and Bunnies. Really being in love means really wanting to live in a different world.

Although the three passions underlying the threefold project of self-realisation, communication and participation are of equal importance, they have not been repressed to an equal extent. While creativity and play have been blighted by prohibitions and by every sort of distortion, love, without escaping from repression, still remains relatively the most free experience. The most democratic, all in all.

Love offers the model of perfect communication: the orgasm, the total fusion of two separate beings. It is a glimpse of a transformed universe. Its intensity, its here-and-now-ness, its physical 
exaltation, its emotional fluidity, its grateful acceptance of the value of change - everything indicates that love will prove the key factor in recreating the world. Our emotionally-dead survival cries out for multidimensional passions. Lovemaking sums up and distils both the desire for, and the reality of, such a way of life. The universe lovers build of dreams and one another's bodies is a transparent universe: lovers want to be at home everywhere.

Love has been able to stay free more successfully than the other passions. Creativity and play have always 'been granted' an official representation, a spectacular acknowledgment which did its best to cut them off at their source. Love has always been clandestine - "being alone together". It turned out to be protected by the bourgeois concept of private life; banished from the day, reserved for work and for consumption, and driven into the darkest corners of the night; lit by the moon. Thus it partly escaped the major mopping-up of daily activities. The same cannot be said for communication, and it is precisely the ashes of false (daily) communication that choke the spark of sexual passion. And today consumer society is extending falsification further and further... into the reaches of the night...

People who talk about 'communication' when there are only things and their mechanical relations are working on the side of the process of reification that they pretend to attack. 'Understanding', 'friendship', 'being happy together' - so much bullshit. All I can see is exploiters and exploited, rulers and ruled, actors and spectators. And all of them flailed like chaff by Power.

Things aren't necessarily expressionless. Anything can become human if someone infuses it with their own subjectivity. But in a world ruled by privative appropriation, the only function of the object is to justify its proprietor. If my subjectivity overflows, if my eyes make the landscape their own, it can only be ideally, without material or legal consequences. In the perspective of power, people and things aren't there for my enjoyment, but to serve a master; nothing really is, everything functions as part of an order of possessions.

There can't be any real communication in a world where almost everything one does is ruled by fetishes. The space between people and things isn't empty: it's packed with alienating mediations. And as power becomes increasingly abstract its own signals become so numerous, so chaotic, as to demand systematic interpretation on the part of a body of scribes, semanticians and mythologists. Brought up to see only objects around him, the proprietor needs objective and objectified servants. Only subjective truth, as historically it becomes objective, can withstand this sort of thing. One must start with immediate experience itself if one wants to attack the most advanced points to which repression has penetrated.

The main pleasure of the middle class seems to have been degrading pleasure in all its forms. It wasn't enough to imprison people's freedom to fall in love in the squalid ownership of marriage (interlarded of course with the occasional one-night stand). It wasn't enough to set things up so that dishonesty and jealousy were bound to follow. The great thing was to sabotage people on the few occasions they really did meet.

Love's despair doesn't come from sexual frustration. It comes from suddenly losing contact with the person in your arms; of both of you suddenly seeing one another as an object. Swedish 
social democracy, as hygienic as ever, has already got its own horrible caricature of free love out on the market: one-night stands dealt out like a deck of cards.

How sickening these endless lies one says and hears! How much one wants to be straight with someone! Sex really does seem to be our only break. Sometimes I think that nothing else is as real, nothing else is as human, as the feel of a woman's body, the softness of her skin, the warmth and wetness of her cunt. Even if there were nothing else at all, this alone would be enough for ever.

But even during really magical moments the inert mass of objects can suddenly become magnetic. The passivity of a lover suddenly unravels the bonds which were being woven, the dialogue is interrupted before it really began. Love's dialectic freezes. Two statues are left lying side by side. Two objects.

Although love is always born of subjectivity - a girl is beautiful because I love her - my desire cannot stop itself objectifying what it wants. Desire always makes an object of the loved person. But if I let my desire transform the loved person into an object, have I not condemned myself to conflict with this object and, through force of habit, to become detached from it?

What can ensure perfect communication between lovers? The union of these opposites:

- the more I detach myself from the object of my desire and the more objective strength I give to my desire, the more carefree my desire becomes towards its object;

- the more I detach myself from my desire insofar as it is an object and the more objective strength I give to the object of my desire, the more my desire finds its raison d'etre in the loved person.

Socially, this playing with one's own attitudes could be expressed by changing partners at the same time as one is attached more or less permanently to a 'pivotal' partner. All these meetings would be the communication of a single purpose experienced in common. I have always wanted to be able to say: "I know you don't love me because you only love yourself. I am just the same. So love me."

Love can only be based on radical subjectivity. The time is up for all self-sacrificial forms of love. To love only oneself through other people, to be loved by others through the love they owe themselves. This is what the passion of love teaches; these are the only conditions of authentic communication.

And love is also an adventure; an attempt to breakfree of dishonesty. To approach a woman in any spectacular, exhibitionistic way, is to condemn oneself to a reified relationship from the very first. The choice is between spectacular seduction - that of the playboy - and the seduction exercised by something that is qualitatively different - the person who is seductive because he isn't trying to seduce.

Sade analyses two possible attitudes. On the one hand, the libertines of the 120 Days of Sodom who can only really enjoy themselves by torturing to death the object they have seduced (and what more fitting homage to a thing than to make it suffer?); or, on the other, the libertines of the Philosophy in the Boudoir, warm and playful, who do all they can to increase one another's 
pleasure. The former are the feudal-type lords, vibrant with hatred and revolt; the latter, the masters without slaves, discovering in one another only the reflection of their own pleasure.

Today, seduction tends to become increasingly sadistic. Sadism is inability to forgive the desired person for being an object. Truly seductive people, on the contrary, contain the fullness of desire in themselves; they refuse to play a part and owe their seductiveness to this refusal. In Sade, this would be Dolmancé, Eugénie or Madame de Saint-Ange. This plenitude can only exist for the desired person if they can recognise their own will to live in the person who desires them. Real seduction seduces only by its honesty. And not everyone is worth seducing. This is what the Beguines of Schweidnitz and their companions (1 $3^{\text {th }}$ century) meant by saying that resistance to sexual advances was the sign of a crass spirit. The Brethren of the Free Spirit expressed the same idea: "Anyone who knows the God inhabiting him carries his own Heaven in himself. By the same token, ignorance of one's own divinity really is a mortal sin. This is the meaning of the Hell which one carries with oneself in earthly life."

Hell is the emptiness left by separation, the anguish of lovers lying side by side without being together. Non-communication is always like the collapse of a revolutionary movement. The will to death is installed where the will to life has disappeared.

Love must be freed from its myths, from its images, from its spectacular categories; its authenticity must be strengthened and its spontaneity renewed. There is no other way of fighting its reification and its recuperation in the spectacle. Love can't stand either isolation or fragmentation; it is bound to overflow into the will to transform the whole of human activity, into the necessity of building a world where lovers feel themselves to be free everywhere.

The birth and the dissolution of the moment of love are bound to the dialectic of memory and desire. At first, desire and the possibility of its reciprocation strengthen one another. In the moment of love itself, memory and desire coincide. The moment of love is the space-time of authentic lived experience, a present containing both the past and the future. At the stage of breaking-up, memory prolongs the impassioned moment but desire gradually ebbs away. The present disintegrates, memory turns nostalgically towards past happiness, while desire foresees the unhappiness to come. In dissolution the separation is real. The failure of the recent past cannot be forgotten and desire gradually melts away.

In love, as in every attempt to communicate, the problem is avoiding the stage of breaking up. One could suggest:

- developing the moment of love as far as one can, in as many directions as possible; in other words, refusing to dissociate it from either creativity or play, raising it from the state of a moment to that of the real construction of a situation;

- promoting collective experiments in individual realisation; thus of multiplying the possibilities of sexual attraction by bringing together a great variety of possible partners;

- permanently strengthening the pleasure-principle, which is the life-blood of every attempt to realise oneself, to communicate or to participate. Pleasure is the principle of unification. Love is desire for unity in a common moment; friendship, desire for unity in a common project. 


\section{The Erotic or the Dialectic of Pleasure}

There is no pleasure which is not seeking its own coherence. Its interruption, its lack of satisfaction, causes a disturbance analogous to Reichian 'stasis'. Repression keeps human beings in a state of permanent crisis. Thus the function of pleasure, and of the anxiety born in its absence, is essentially a social function. The erotic is the development of the passions as they become unitary, a game of unity and variety, without which revolutionary coherence cannot exist ("Boredom is always counterrevolutionary" - I.S. no. 3).

Wilhelm Reich attributes most of neurotic behaviour to disturbances of the orgasm, to what he called 'orgastic impotence'. He maintains that anxiety is created by inability to experience a complete orgasm, by a sexual discharge which fails to liquidate all the excitement, all the foreplay, leading up to it. The accumulated arid unspent energy becomes free-floating and is converted into anxiety. Anxiety in its turn still further impedes future orgastic potency.

But the problem of tensions and their liquidation doesn't just exist on the level of sexuality. It characterises all human relationships. And Reich, although he sensed that this was so, fails to emphasise strongly enough that the present social crisis is also a crisis of an orgastic nature. If "the source of neurotic energy lies in the disparity between the accumulatiorn and the discharge of sexual energy", it seems to me that the source of energy of our neuroses is also to be found in the disparity between the accumulation and the discharge of the energy brought into use by human relationships. Total enjoyment is still possible in the moment of love, but as soon as one tries to prolong this moment, to extend it into social life itself, one cannot avoid what Reich called 'stasis'. The world of the dissatisfactory and the unconsummated is a world of permanent crisis. What would a society without neurosis be like? An endless banquet. Pleasure is the only guide.

"Everything is feminine in what one loves", wrote La Mettrie, "the empire of love recognises no other frontiers than those of pleasure". But pleasure itself doesn't recognise any frontiers. If it isn't growing, it is beginning to disappear. Repetition kills it; it can't adapt itself to the fragmentary. The principle of pleasure cannot be separated from the totality.

The erotic is pleasure seeking its coherence. It's the development of passions becoming communicative, interdependent, unitary. The problem is recreating in social life that state of total enjoyment known in the moment of love. Conditions allowing a game with unity and variety, that is to say, free and transparent participation in particular achievements.

Freud defined the goal of Eros as unification or the search for union. But when he maintains that fear of being separated and expelled from the group comes from an underlying fear of castration, his proposition should be inverted. Fear of castration comes from the fear of being excluded, not the other way round. This anxiety becomes more marked as the isolation of individuals in an illusory community becomes more and more difficult to ignore.

Even while it seeks unification, Eros is essentially narcissistic and in love with itself. It wants a world to love as much as it loves itself. Norman O. Brown, in Life Against Death, points out the contradiction. How, he asks, can a narcissistic orientation lead to union with beings in the world? "in love, the abstract antimony of the Ego and the Other can be transcended if we return to the concrete reality of pleasure, to a definition of sexuality as being essentially a pleasurable activity of the body, and if we see love as the relationship between the Ego and the sources of pleasure." 
One could be more exact: the source of pleasure lies less in the body than in the possibility of free activity in the world. The concrete reality of pleasure is based on the freedom to unite oneself with anyone who allows one to become united with oneself. The realisation of pleasure passes through the pleasure of realisation, the pleasure of communication through the communication of pleasure, participation in pleasure through the pleasure of participation. It is because of this that the narcissism turned towards the outside world, the narcissism Brown is talking about, can only bring about a wholesale demolition of social structures.

The more intense pleasure becomes the more it demands the whole world. "Lovers, seek greater and greater pleasure," said Breton. This is a revolutionary demand.

Western civilisation is a civilisation of work and, as Diogenes observed: "Love is the occupation of the unoccupied." With the gradual disappearance of forced labour, love takes on a greater and greater importance. It has become the major resource to develop. And it poses a direct threat to every kind of authority. Because the erotic is unitary, it is also acceptance of change. Freedom knows no propaganda more effective than people calmly enjoying themselves. Which is why pleasure, for the most part, is forced to be clandestine, love locked away in a bedroom, creativity confined to the back-stairs of culture, and alcohol and drugs cower under the shadow of the outstretched arm of the law...

The morality of survival has condemned both the diversity of pleasures and their union-invariety in order to promote obsessive repetition. But if pleasure-anxiety is satisfied with the repetitive, true pleasure can only exist in terms of diversity-within-unity. Clearly the simplest model of the erotic is the pivotal couple. Two people live their experiences as honestly and as freely as possible. This radiant complicity has all the charm of incest. Their wealth of common experiences can only lead to a brother and sister relationship. Great loves have always had something incestuous about them; one could deduce that love between brothers and sisters was privileged from the very first, and that it should be worked on in every possible manner. It's high time to break this, the most ancient and ugliest of all taboos, and to break it once and for all. The process could be described as sororisation. A wife and a sister all of whose friends are also my wives and sisters

In the erotic, there is no perversion apart from the negation of pleasure: its distortion into pleasure-anxiety. What matters the spring so long as the water is pure? As the Chinese say: Immobile in one another, pleasure bears us.

And, finally, the search for pleasure is the best safeguard of play. It defends real participation, it protects it against self-sacrifice, coercion and dishonesty. The actual degree of intensity pleasure reaches marks subjectivity's grasp on the world. Thus, flirtatiousness is playing with desire as it is born; desire, playing with passion as it is born. And playing with passion finds its coherence in poetry, whose essentially revolutionary nature can never be over-emphasised.

Does this mean that the search for pleasure is incompatible with pain? On the contrary, it's a question of re-inventing pain. Pleasure-anxiety is neither pleasure nor pain; it's just scratching yourself and letting the itch get worse and worse. What is real pain? A set-back in the game of desire or passion; a positive pain crying out with a corresponding degree of passion for another pleasure to construct. A delay in full participation. 


\section{The Project of Participation}

A society based on organised survival can only tolerate false, spectacular forms of play. But given the crisis of the spectacle, playfulness, distorted in every imaginable way, is being reborn everywhere. From now on it has all the features of social upheaval and, beyond its negativity, the foundations of a society of real participation can be detected. To play means to refuse leaders, self-sacrifice and roles, to embrace every form of self-realisation and to be utterly, painfully, honest with all one's friends (1). Tactics are the polemical stage of the game. Individual creativity needs an organisation concentrating and strengthening it. Tactics entail a certain kind of hedonistic foresight. The point of every fragmentary action must be the total destruction of the enemy. Industrial societies have to evolve their own specific forms of guerilla warfare (2). Diversion is the only possible revolutionary use of the spiritual and material values distributed by consumer society: supersession's ultimate deterrent (3).

1

Economic necessity and play don't mix. Financial transactions are deadly serious: you don't fool around with money. The elements of play contained within feudal economy were gradually squeezed out by the rationality of money exchanges. Playing with exchange means to barter products without worrying too much about strictly standardised equivalents. But from the moment that capitalism forced its commercial relationships on the world, fantasy was forbidden; and the dictatorship of commodities today shows clearly that it intends to enforce these relationships everywhere, at every level of life.

The pastoral relationships of country life in the high Middle Ages tempered the purely economic necessities of feudalism with a sort of freedom; play often took the upper hand even in menial tasks, in the dispensing of justice, in the settling of debts. By throwing the whole of everyday life onto the battlefield of production and consumption, capitalism crushes the urge to play while at the same time trying to harness it as a source of profit. So, over the last few decades, we have seen the attraction of the unknown turned into mass-tourism, adventure turned into scientific expeditions and the great game of war turned into strategic operations. Taste for change now rests content with a change of taste...

Contemporary society has banned all real play. It. has been turned into something only children do. And today children themselves are getting more and more pacifying gadget-type toys rammed down their throats. The adult is only allowed falsified and recuperated games: competitions, T.V. sport, elections, gambling... Yet at the same time it's obvious that this kind of rubbish can never satisfy anything as strong as people's desire to play - especially today when gameplaying could flourish as never before in history.

The sacred knows how to cope with the profane and deconsecrated game: witness the irreverent and obscene carvings in cathedrals. Without concealing them, the Church embraced cynical laughter, biting fantasy and nihilistic scorn. Under its mantle the demonic game was safe. Bourgeois power, on the contrary, puts play in quarantine, isolates it in a special ward, as if it wanted to stop it infecting other human activities. Art is this privileged and despised area set apart from commerce. And it will stay that way until economic imperialism refits it in its turn as a spiritual supermarket. Then, hunted down everywhere, play will burst out everywhere. 
It was in fact from art that play broke free. The eruption was called Dada. "The dadaist events awoke the primitive-irrational play instinct which had been held down an the audience", said Hugo Ball. On the fatal slope of plague and mockery Art dragged down in its fall the whole edifice which the Spirit of Seriousness had built to the greater glory of the bourgeoisie. So that today the expression on the face of someone playing is the expression on the face of a rebel. Henceforward, the total game and the revolution of everyday life are one.

The desire to play has returned to destroy the hierarchical society which banished it. At the same time it is setting up a new type of society, one based on real participation. It is impossible to foresee the details of such, a society - a society in which play is completely unrestricted but one could expect to see the following characteristics:

- rejection of all leaders and all hierarchies;

- rejection of self-sacrifice;

- rejection of roles;

- freedom of genuine self-realisation;

- utter honesty.

Every game has two preconditions: the rules of playing and playing with the rules. Watch children at play. They know the rules of the game, they can remember them perfectly well but they never stop breaking them, they never stop dreaming up new ways of breaking them. But for them, cheating doesn't have the same connotations as it does for adults. Cheating is part of the game, they play at cheating, accomplices even in their arguments. What they are really doing is spurring themselves on to create new games. And sometimes they are successful: a new game is found and unfolds. They revitalise their playfulness without interrupting its flow.

The game dies as soon as an authority crystallises, becomes institutionalised and clothed in a magical aura. Even so playfulness, however lighthearted, never loses a certain spirit of organisation and its required discipline. If a play leader proves necessary, his power is never wielded at the expense of the autonomous power of each individual. Rather it is the focus of each individual will, the collective counterpart of each particular desire. So the project of participation demands a coherent organisation allowing the decisions of each individual to be the decisions of everyone concerned. Obviously small intimate groups, micro-societies, offer the best conditions for such experiments. Within them the game can be the sole ruler of the intricacies of communal life, harmonising individual whims, desires and passions. Especially so since this game will reflect the insurrectionary game played by the group as a whole, forced upon them by their intention to live outside the law.

The urge to play is incompatible with self-sacrifice. You can lose, pay the penalty, submit to the rules, spend an unpleasant quarter of an hour, that's the logic of the game, not the logic of a Cause, not the logic of self-sacrifice. Once the idea of sacrifice appears the game becomes sacred and its rules become rites. For those who play, the rules, along with the ways of playing with them, are an integral part of the game. In the realm of the sacred, on the contrary, rituals cannot be played with, they can only be broken, can only be transgressed (not to forget that pissing on the altar is still a way of paying homage to the Church). Only play can deconsecrate, open up the possibilities of total freedom. This is the principle of diversion, the freedom to change the sense 
of everything which serves Power; the freedom, for example, to turn the cathedral of Chartres into a fun-fair, into a labyrinth, into a shooting-range, into a dream landscape...

In a group revolving around play, manual and domestic chores could be allotted as penalties, as the price one pays for losing a point in a game. Or, more simply. they could be used to employ unoccupied time, as a sort of active rest; assuming, as a contrast, the value of a stimulant and making the resumption of play more exciting. The construction of such situations can only be based on the dialectic of presence and absence, richness and poverty, pleasure and pain, the intensity of each pole accentuating the intensity of the other.

In any case, any technique utilised in an atmosphere of sacrifice and coercion loses much of its cutting edge. Its actual effectiveness is mixed up with a purely repressive purpose, and to repress creativity is to reduce the productivity of the machine repressing it. Work can only be non-alienating and productive if you enjoy doing it.

The role one plays must be the role one plays with. The spectacular role demands complete conviction; a lucid role, on the contrary, demands a certain distanciation. One has to watch oneself over one's own shoulder, in much the same sort of way that professional actors like to swop jokes sotto voce in between two dramatic tirades. Spectacular organisation is completely out of its depth with this sort of thing. The Marx Brothers have shown what a role can become if you play with it. The only pity is that the Marx Brothers were stuck with the cinema. What would happen if a game with roles started in real life?

When someone begins to play a permanent role, a serious role, he either wrecks the game or it wrecks him. Consider the unhappy case of the provocateur. The provocateur is the specialist in collective games. He can grasp their techniques but not their dialectic. Maybe he could succeed in steering the group towards offensive action - for provocateurs always push people to attack here and now - if only he wasn't so involved in his own role and his own mission that he can never understand their need to defend themselves. Sooner or later this incoherence in his attitude towards offensive and defensive action will betray the provocateur, and lead him to his untimely end. Add who makes the best provocateur? The play leader who has become the boss.

Only desire to play can lead to a community whose interests are identical with those of the individual. The traitor, unlike the provocateur, appears quite spontaneously in revolutionary groups. When does he appear? Whenever the spirit of play has died in a group, and with it, inevitably, the possibility of real involvement. The traitor is one who cannot express himself through the sort of participation he is offered and decides to 'play' against this participation,. not to correct but to destroy it. The traitor is an illness of the old age of revolutionary groups. Selling out on play is an act of treachery which justifies all others.

\section{Tactics}

Tactics are the polemical stage of the game. They provide the necessary continuity between poetry as it is born (play) and the organisation of spontaneity (poetry). Of an essentially technical nature, they prevent spontaneity burning itself out in the general confusion. We know how cruelly absent tactics have been from most popular uprisings. And we also know just how offhand historians can be about spontaneous revolutions. No serious study, no methodical analysis, nothing approaching the level of Clausewitz's book on war. Revolutionaries have ignored Makhno's battles almost as thoroughly as bourgeois generals have studied Napoleon's.

A few observations, in the absence of a more detailed analysis. 
An efficiently hierarchised army can win a war, but not a revolution; an undisciplined mob can win neither. The problem then is how to organise without creating a hierarchy; in other words, how to make sure that the leader of the game doesn't become just "the Leader". The only safeguard against authority and rigidity setting in is a playful attitude. Creativity plus a machine gun is an unstoppable combination. Villa and Makhno's troops routed the most experienced professional soldiers of their day. But once playfulness begins to repeat itself, the battle is lost. The revolution fails so that its leader can be infallible. Why was Villa defeated at Celaya? Because he fell back on old tactical and strategic games, instead of making up new ones. Technically, Villa was carried away by memories of Ciudad Juarez, where his men had fallen on the enemy from the rear by silently cutting their way through the walls of house after house. He failed to see the importance of the military advances brought about by the 1914-18 war, machine gun nests, mortars, trenches, etc. In political terms, he failed to see the importance of gaining the support of the industrial proletariat. It's no coincidence that Obregon's victorious army which wiped out Villa's Dorados included both workers' militias and German military advisers.

The strength of revolutionary armies lies solely in their creativity. Frequently the first days of an insurrection are a walk-over simply because nobody paid the slightest attention, to the rules by which the enemy played the game: because they invented a new game and because everyone took part in its elaboration. But if this creativity flags, if it becomes repetitive, if the revolutionary army becomes a regular army, then you can see blind devotion and hysteria try in vain to make up for military weakness. Infatuation with past victories breeds terrible defeats. The magic of the Cause and the Leader replaces the conscious unity of the will to live and the will to conquer. In 1525, having held the princes at bay for two years, 40,000 peasants whose tactics had given way to religious fanaticism, were hacked to pieces at Frankenhaussen; the feudal army only lost three men. In 1964, at Stanleyville, hundreds of Mulélists, convinced they were invincible, allowed themselves to be massacred by throwing themselves on to a bridge defended by two machine guns. Yet these were the same men who previously had captured trucks and arms consignments from the A.N.C. by pitting the roads with elephant traps.

Hierarchical organization and its counterpart, indiscipline and incoherence, are equally inefficient. In a traditional war, the inefficiency of one side overcomes the inefficiency of the other through purely technical superiority; in revolutionary war, the tactical poetry of the rebels steals from the enemy both their weapons and the time in which to use them, thus robbing them of their only possible superiority. But if the guerillas begin to repeat themselves, the enemy can learn the rules of their game; at which point counter-guerilla can, if not destroy, at least badly damage a popular creativity which has already hobbled itself.

If troops are to refuse to kow-tow to leaders, how can the discipline necessary for warfare be maintained? How can disintegration be avoided? Revolutionary armies tend to oscillate between the Scylla of devotion to a Cause and tile Charybdis of untimely pleasure seeking.

Stirring pleas, in the name of freedom, for restraint and renunciation lay the foundations of future slavery. But equally, premature rejoicing and the quest for small pleasures are always followed closely by the mailed fist of the bloody weeks of "restoring order". Discipline and cohesion can only come from the pleasure principle. The search for the greatest possible pleasure must always run the risk of pain: this is the secret of its strength. Where did the old troopers of the ancien 
régime find the strength to besiege a town, be repulsed ten times and still attack ten times more? In their passionate expectation of festivity - in this case, it must be admitted, largely looting and rape - of pleasure all the sweeter for having been attained so slowly. The best tactics go hand in hand with anticipation of future pleasure. The will to live, brutal and unrestrained, is the fighter's deadliest secret weapon. A weapon which should be used against anyone who endangers it: a soldier has every reason to shoot his officers in the back. For the same reasons, revolutionary armies will be stronger if they make each man a resourceful and independent tactician; someone who takes his pleasures seriously..

In the coming struggles, the desire to live life to the full will replace pillage as a motive. Tactics will merge with the science of pleasure - for the search for pleasure is already pleasure itself. Lessons in these tactics are given free every day. Anyone who is ready to learn, from his everyday experience, what undermines his independence and what makes him stronger, will gradually earn his colours as a tactician.

However, no tactician is isolated. The will to destroy this sick world calls for a federation of the tacticians of everyday life. It's just such a federation that the S.I. intends to equip technically without delay. Strategy is collectively building the launching-pad of the revolution on the tactics of individual everyday life.

The ambiguous concept of 'humanity' sometimes causes spontaneous revolutions to falter. All too often the desire to make man the heart of a revolutionary programme has been invaded by a paralysing humanism. How many times have revolutionaries spared the lives of their own future firing-squad, how many times have they accepted a truce which meant no more to their enemies than the opportunity of gathering reinforcements? The ideology of humanity is a fine weapon for counter-revolution, one which can justify the most sickening atrocities (the Belgian paras in Stanleyville).

There can be no negotiation with the enemies of freedom, there's no quarter which can be extended to man's oppressors. The annihilation of counter-revolutionaries is the only 'humanitarian' act which can prevent the ultimate inhumanity of an integrally bureaucratised humanism.

Lastly: power must be totally destroyed by means of fragmentary acts. The Struggle for purely economic emancipation has made survival possible for everyone by making anything beyond survival impossible. But the traditional workers movement was clearly struggling for more than that: for a total change in people's way of life. In any case, the wish to change the whole world at one go is a magical wish, which is why it can so easily degenerate into the crudest reformism. Apocalypticism and demands for gradual reform end up by merging in the marriage of reconciled differences. It isn't surprising that pseudo-revolutionary parties always end by pretending that compromises are the same as tactics.

The revolution cannot be won either by accumulating minor victories or by an all-out frontal assault. Guerilla war is total.

This is the path on which the S.I. is set: calculated harrassment on every front - cultural, political, economic and social. Concentrating on everyday life will ensure the unity of the combat. 


\section{Diversion}

In its broadest sense, diversion is an all embracing re-entry into play. It is the act by which play grasps and reunites beings and things which were frozen solid in a shattered hierarchic array.

One evening, as night fell, my friends and I wandered into the Palais de fustice in Brussels. The building is a monstrosity, crushing the poor quarters beneath it and guarding, like a sentry, the fashionable Avenue Louise - out of which, some day, we will make a breathtakingly beautiful bombsite. As we wandered through the labyrinth of corridors, staircases, and suite after suite of rooms, we discussed what could be done to make the place habitable; for a time we occupied the enemies' territory; through the peer of our imagination we transformed the thieves den into a fantastic fun-falr, into a sunny pleasure dome, where the most amazing adventures would, for the first time, be really lived. In short, diversion is the basic expression of creativity. Day-dreaming diverts the world. People divert, just as Jourdain did with prose and James Joyce did with Ulysses, spontaneously and with considerable reflection.

It was in 1955 that Debord, struck by Lautréamont's systematic use of diversion, first drew attention to the virtually unlimited possibilities of the technique. In 1960, Jorn was to write: "Diversion is a game which can only be played as everything loses its value. Every element of past culture must either be reinvested in reality or be scrapped." Debord, in Internationale Situationniste no. 3, developed the concept still further: "The two basic principles of diversion are the loss of importance of each originally independent element (which may even lose its first sense completely), and the organisatlon of a new significant whole which confers a fresh meaning on each element." Recent history allows one to be still more precise. From now on it's clear that:

- as more and more things rot and fall apart, diversion appears spontaneously. Consumer society plays into the hands of those who want to create new significant wholes;

- culture is no longer a particularly privileged theatre. The art of diversion can be an integral part of any rebellion against the nature of everyday life;

- since part-truths rule our world, diversion is now the only technique at the service of a total view. As a revolutionary act, diversion is the most coherent, most popular and the best adapted to revolutionary practice. By a sort of natural evolution - the desire to play - it leads people to become more and more extreme, more and more radical.

Our experience is falling to pieces about our ears, and its disintegration is a direct consequence of the development of consumer society. The phase of devaluation, and thus the possibility of diversion, is the work of contemporary history. Diversion has become part of the tactics of supersession; an essentially positive act.

While the abundance of consumer goods is hailed everywhere as a major step forward in evolution, the way these goods are used by society, as we know, invalidates all their positive aspects. Because the gadget is primarily a source of profit for capitalism and the socialist bureaucracies, it cannot be used for any other ends. The ideology of consumerism acts like a fault in its manufacture, it sabotages the commodity coated in it; it turns what could be the material equipment of happiness into a new form of slavery. In this context, diversion broadcasts new ways of using commodities; it invents superior uses of goods, uses by which subjectivity can strengthen itself with something that was originally marketed to weaken it. The problems of tactics and strategy 
revolve around our ability to turn against capitalism the weapons that commercial necessity has forced it to distribute. Methods of diversion should be spread as an ABC Of The Consumer Who Wishes To Stop Being So.

Diversion, which forged its first weapons from art, has now become the art of handling every sort of weapon. Having first appeared amidst the cultural crisis of the years 1910-25, it has gradually spread to every area touched by social decomposition. Despite which, art still offers a field of valid experiment for the techniques of diversion; and there's still much to be learnt from the past. Surrealism failed because it tried to reinvest dadaist anti-values which had not been completely reduced to zero. Any other attempt to build on values which have not been thoroughly purged by a nihilistic crisis will end in the same way; with recuperation. Contemporary cyberneticians have taken their 'combinatory' attitude towards art so far as to believe in the value of any accumulation of disparate elements whatsoever, even if the particular elements haven't been devalued at all. Pop Art or Jean-Luc Godard, it's the same apologetics of the junk-yard.

Diversion, self-critical language, is our only possible means of communication. There are no limits to creativity. There is no end to diversion. 


\section{Chapter 24. The Interworld and the New Innocence}

The interworld is the wasteland of subjectivity, the sphere where the residues of power and of its corrosion mix with the will to live (1). The new innocence liberates the monsters of inferiority, and hurls the murky violence of the interworld against the old order of things from which it stems (2).

1

On the fringes of uneasy subjectivity the canker of power eats away. There thrives undying hate, the demons of revenge, the tyranny of envy, the rancour of frustrated desire. It may be a marginal infection, but it threatens every side; an interworld.

The interworld is the no-man's land of subjectivity. Its borders tremble with the fundamental cruelty of cop and rebel, oppression and the poetry of revolt. Halfway between its recuperation by the spectacle and its revolutionary use, the dreamer's extra-space-time spawns monstrous creations after the image of his own desires and that of power. The increasing poverty of daily life has turned into a sort of public amenity suitable for every kind of investigation, an open battlefield between creative spontaneity and what corrupts it. As a faithful explorer of the mind, Artaud sums up perfectly this evenly-matched struggle: "My unconscious is only mine in dreams, but are the forms I see there going to come to birth or are they some foul abortion I've spewed up? The subconscious is shaped by the premises of my interior will, but I'm not really sure who reigns there; I don't believe it's me, but rather a flood of conflicting desires which, I don't know why, think in me and do nothing but struggle endlessly for total possession over me. But I reencounter every one of these perverse desires, whose temptations treat me with such temerity, in the preconscious - only this time all my conscious wits are about me, and although the perverse desires break in waves over me, the important thing is that I feel myself there... I feel therefore that if I travelled upstream, I ought to emerge in my preconscious at the point where I could see myself evolve and desire." Further on, Artaud says: "Peyote led me there."

The adventures of the hermit of Rodez sound off a warning. His break with the Surrealist movement is a turning point. He charged them with getting caught up in Bolshevism; with serving a revolution - which be it mentioned in passing, drags Kronstadt's corpses along with it - instead of making the revolution serve them. Artaud was absolutely right to blame the helplessness of the movement on its failure to base its revolutionary coherence on its richest truth - subjectivity before everything. But no sooner had he broken with Surrealism than he veered off into solipsistic madness and magic. He was no longer interested in realising his subjective desire by transforming the world. Instead of externalising what lies inside, he did the opposite, and made it holy, finding in the solid world of analogies the eternal primal myth, to which revelation only the roads of impotence lead. Those who are reluctant to cast out the flames that devour them are just asking to get burnt, consumed, according to the laws of the consumable, in the Nessus' shirt 
of ideology - be it of drugs, art, psychoanalysis, theosophy or revolution, it never ever changes history.

The world of imagination is the exact science of possible solutions, not a parallel world granted to the mind in compensation for its real failures. It is a force destined to bridge the gap between internal and external. praxis condemned for now to inaction.

With its phantoms, its obsessions, its outbursts of hate, its sadism, the interworld is like a cage of wild animals driven mad by their imprisonment. Anyone is free to go down there by means of dreams, drugs, alcohol or the disordering of the senses. Its violence asks only to be freed. A good climate in which to steep oneself, if only to reach the consciousness that dances and kills - what Norman O. Brown calls the 'Dionysian consciousness'.

2

The bloody dawn of riots doesn't dissolve the monstrous creatures of the night. It clothes them in light and fire, and scatters them through towns and across the countryside. The new innocence is baleful dreams come true. Subjectivity only constructs itself by destroying what hampers it, and the violence necessary to this end is drawn from the interworld. The new innocence is the lucid construction of annihilation.

The most peaceful of men are full of bloody dreams. We know the price of treating solicitously those whom we can't strike down now, using kindness when we can't use force. I owe a great weight of hatred to those who've failed to break me. How can we liquidate hate without liquidating its causes? In the barbarity of riots, the arson, the popular savagery, the excesses that terrify bourgeois historians, we find exactly the right vaccine against the cold atrocity of the forces of order and hierarchical oppression.

In the new innocence, the interworld suddenly erupts and submerges oppressive structures. The game of nothing-but violence is engulfed by the everything-and violence of the revolutionary game.

The shock of freedom works miracles. Nothing can resist it, neither mental illness, remorse, guilt, the feeling of powerlessness, nor the brutalisation created by the environment of power. When a waterpipe burst in Pavlov's laboratory, not one of the dogs that survived the flood retained the slightest trace of his long conditioning. Could the tidal wave of great social upheavals have less effect on men than a burst waterpipe on dogs?, Reich recommends explosions of anger for emotionally blocked and muscularly armoured neurotics. This type of neurosis seems particularly prevalent today: it's survival sickness. The most coherent explosion of anger has a great chance of being a general uprising.

Three thousand years of living in the shadows can't withstand ten days of revolutionary violence. The reconstruction of society will simultaneously reconstruct everyone's unconscious.

The revolution of everyday life will blot out ideas of justice, punishment and torture, which are notions dependent on exchange and fragmentation. We don't want to be judges, but, by 
destroying slavery, masters without slaves recovering a new innocence and gracefulness in living. We have to destroy the enemy, not judge him. Whenever Durruti's column freed a village, they would assemble the peasants, ask which were the Fascists and shoot them on the spot. The next revolution will do the same. With perfect composure. We know there'll be no-one to judge us, nor will there ever be judges again, because we will have gobbled them up.

The new innocence entails destroying an order of things that has always tried to pin down the art of living and which today is threatening what remains of authentically lived experience. I don't need reasons to defend my freedom.

But at every moment power is legally defending me, (as I am legally defending myself against it!) In this brief exchange between the anarchist Duval and the policeman sent to arrest him, the new innocence can recognise its spontaneous jurisprudence:"Duval, I arrest you in the name of the law." "And I suppress you in the name of freedom."

Things don't bleed. Those heavy with the dead weight of things will die the death of things. Victor Serge recounts that during the sack of Razoumovskoe the revolutionaries smashed some porcelain; and when they were criticised for having done so, they replied: "We'll smash all the porcelain in the world to transform life. You love things too much and people too little... You love men too much the way you love things, and man you don't love enough." What we don't need to destroy is worth saving: that's the most succinct version of our future penal code. 


\section{Chapter 25. You're Fucking Around with Us? - Not for Long!}

(Sequel to 'Vous foutez-vous de nous?' - Address oft he Sansculottes of the Rue Mouffetard to the Convention, 9 December 1792)

In Watts, Prague, Stockholm, Stanleyville, Gdansk, Turin, Port Talbot, Cleveland, Cordoba, Amsterdam, wherever the act and wareness of refusal generates passionate break-outs from the factories of collective illusion, the revolution of everyday life is under way. The struggle intensifies as misery becomes universal. What for years were reasons for fighting specific issues - hunger, restrictions, boredom, illness, anxiety, isolation, deceit - now reveal misery's fundamental rationality, its omnipresent emptiness, its appalling oppressive abstraction. For this misery, the world of hierarchical power, the world of the State, of sacrifice, exchange and the quantitative - the commodity as will and representation of the world - is held responsible by those moving towards an entirely new society that is still to be invented and yet is already among us. All over the globe, revolutionary praxis, like a photographic exposer, is transforming negative into positive, lighting up the hidden face of the earth with the fires of rebellion to ink in the map of its triumph.

Only genuine revolutionary praxis gives the organisation of armed revolt the precision without which even the best proposals remain tentative and partial. But this same praxis shows a rapid corruption the moment it breaks with its own rationality. That rationality is not abstract but concrete supersession of that universal and empty form, the commodity - and is alone in allowing a non-alienating objectification: the realization of art and philosophy in the individual's daily life. Such a rationality's line of force and extension is born of the deliberate encounter of two poles under tension. It's the spark struck off between subjectivity, extracting the will to be everything from the totalitarianism of oppressive conditions, and the historical withering way of the generalised commodity system.

Existential conflicts are not qualitatively different from those inherent in the whole of mankind. That's why men can't hope to control the laws governing their general history if they can't simultaneously control their own individual histories. If you go for revolution and neglect your own self, then you're going about it backwards, like all the militants. Against voluntarism and the mystique of the historically inevitable revolution, we must spread the idea of a plan of attack, and a means, both rational and passionate, in which immediate subjective needs and objective contemporary conditions are dialectically united. In the dialectic of part and totality, the curved slope of revolution is the project to construct daily life in and through the struggle against the commodity form, so that each phase of the revolution is carried in the style of its final outcome. No maximum program, no minimum program, and no transitional programme - instead a complete strategy based on the essential characteristics of the system we want destroyed.

Between the increasingly disorganised old society and the new society yet to be created, the Situationist International offers an example of a group in search of its revolutionary coherence. 
As with all groups bearing the seeds of poetry, its importance is as a model for the new social organisation. It must therefore prevent external oppression (hierarchy, bureaucratisation...) reappearing inside the movement, by insuring that participation is subordinated to the maintenance of real equality between all its members, not as a metaphysical right, but on the contrary as the norm to attain. It is precisely to avoid authoritarianism and passivity (leaders and militants) that the group should unhesitatingly move against any compromise, drop in the theoretical level or lack of practical activity. We can't tolerate people whom the dominant regime so happily puts up with. Exclusion and rupture are the only defences of coherence in danger.

In the same way, the project of centralising scattered poetry involves the ability to recognise or encourage autonomous revolutionary groups, radicalise them, and federate them without ever taking them over. The Situationist International has an axial function: to be everywhere the ax which popular agitation wields and which in turn amplifies the initial movement. The Situationists will recognise these groups on the basis of their revolutionary coherence.

The moment of revolt, which means now, is hallowing out for us in the hard rock of our daily lives, days that miraculously retain the delicious colours and the dreamlike charm which - like an Aladdin's cave, magical and prismatic in an atmosphere all its own - is inalienably ours. The moment of revolt is childhood rediscovered, time put to everyone's use, the dissolution of the market and the beginning of generalised self-management.

The long revolution is creating small federated microsocieties, true guerilla cells practising and fighting for this self-management. Effective radicality authorises all variations and guarantees every freedom. That's why the Situationists don't confront the world with: "Here's your ideal organisation, on your knees!" They simply show by fighting for themselves and with the clearest awareness of this fight, why people really fight each other and why they must acquire an awareness of the battle.

(1963-1965)

Raoul Vaneigem 


\section{A Toast to Revolutionary Workers}

Radical criticism has merely analysed the Old World and its negation. It must now either realise itself in the practical activity of the revolutionary masses or betray itself by becoming a barrier to that activity.

So long as the project of the whole human being remains the spectre haunting the void of unmediated self-realisation, so long as the proletariat does not achieve a de facto reappropriation of theory from those who have distilled it from the proletariat's own movement, so long will each radical step forward be followed by ideology's two steps back.

By urging proletarians to lay hold of a theory derived from direct daily experience (and from the lack of it), my Traité de savoir-vivre cast its lot unequivocably with the cause of transcendence. But by the same token it laid itself open to all the falsifications that are bound to accompany any and all delay in putting these lessons into insurrectional practice. The moment radical theory becomes independent of the self-movement of revolutionary consciousness, as when this consciousness is suddenly inhibited by history, it becomes other than itself while remaining itself, and cannot completely evade capture by a parallel but contrary movement - by regression towards separated thought, towards the spectacle. Even when a book like this one contrives to embody its own self-criticism, this merely exposes it to ideological parasites; these run the gamut, in this instance, from subjectivism to nihilism, via communitarianism and apolitical hedonism to say nothing of our old friends the puffed-up bullfrogs of critical criticism.

Before too long, radical working-class action will subordinate the spheres of production and consumption to the needs and passions of individuals. Working-class action is, initially at least, the only force capable of subverting these spheres. The historical procrastinations of this movement show, however, that the portion of the proletariat which has no direct control over economic processes has been capable at best, in its ascendant phase, of framing and disseminating a theory which it could not itself actualise or adjust. In a period of defeat, moreover, it has turned this theory into a regression of the intellect: a consciousness which never attained a true purchase on its own time has developed into a strictly retrospective parading of banners.

The subjective expression of the situationist project reached its highest point when it prepared the ground for May 1968 and accelerated the growth of consciousness of the new forms of exploitation. Its lowest ebb has been an intellectualised reading born of the inability of a large number of people to destroy what can only be destroyed (through sabotage and subversion not occupations) by the workers responsible for the economy's key sectors.

The situationist project nevertheless represented the most advanced practical thought of a proletarian sector with no access to the levers of the commodity process. What is more, in its formulation this project never for a moment relinquished as its appointed and indivisible task the annihilation of the social organisation of survival in favour of generalised workers' control. It is therefore bound to rediscover its real internal movement in a working-class context, and there resurface, leaving the spectacle's hot-air specialists picking over the carcass of its former incarnation to see what use they can make of these remains. 
Radical theory belongs to whoever causes it to progress. To defend it against books or other cultural merchandise wherein it reposes too often and too long on display is not to set an antiwork, anti-self-sacrifice, anti-hierarchy worker against a proletarian restricted to an unarmed consciousness of the same refusals; rather, it is to call upon those who find themselves at the most basic level of the unitary struggle against the society of survival to use the forms of expression most effectively available to them, and to perform revolutionary deeds which forge their own language by creating conditions from which there is no possible turning back. Sabotage of the forced-labour system, destruction of the processes of commodity production and reproduction, expropriation of stores and plant in the name of the revolutionary forces and of all those allied with them by reason of passionate attraction - here are means capable of putting an end, not only to the bureaucratic reserve army constituted by intellectualising workers and workerist intellectuals alike, but also to the intellectual-manual dichotomy itself - and indeed eventually to the whole world of separations. Down with the division of labour and the universal factory! Long live the unity of non-work and generalised workers' control!

The main theses of the Traité de savoir-vivre must now find corroboration of a concrete sort in the actions of its anti-readers: not in the shape of student agitation but in the shape of total revolution. The task of theory henceforth is to carry violence where violence already holds sway. Workers of Asturias, Limburg, Poznan, Lyons, Detroit, Csepel, Leningrad, Canton, Buenos Aires, Johannesburg, Liverpool, Kiruna, Coimbra - it is you who are destined to let the entire proletariat add the joy of revolution made for one and for all to the lesser, everyday pleasures of love, iconoclasm and obedience to the dictates of passion!

Without the criticism of arms, the arms of criticism are but weapons of suicide. Many proletarians successfully avoid the despair of terrorism and the poverty of militantism only to become voyeurs of the working class, spectators of their own shelved potential. Cuckolded and defeated as revolutionaries sans revolution, they settle for the role of revolutionary-by-proxy, awaiting the moment when the falling rate of petty-bureaucratic power hands them a chance to offer themselves as mediators and play the leader under the banner of their very inability to smash the spectacle. They are the reason why the organisation of insurgent workers - the only revolutionary organisation needed henceforth - must be the work of the insurgent workers themselves. Otherwise the proletariat as a whole will have no organisational model in its fight for generalised workers' control. The advent of this type of organisation will mark the final passing of repressive organisations (States, parties, unions, hierarchical groups of all kinds) along with their critical corollary, that fetishism of organisation which flourishes in the ranks of the non-productive proletariat. The immediate practice of such an organisation will eradicate the contradiction between voluntarism and realism which marked the limits of the Situationist International ${ }^{1}$ : confronted by the perpetual re-emergence within itself of the relationships characteristic of the dominant world outside, that group found that its own means of dealing with this situation, exclusion and rupture, were inadete, and a way was never found to harmonise inter-subjective agreements and differences. It will become clear eventually that the portion of the proletariat with no concrete possibility of subverting the means of production is in need not of organisations but rather of individuals acting for themselves. Such individuals may federate from time to time into commando groups for the purposes of sabotage (attacks on the apparatus of repression, occupation of radio stations, etc). They will intervene wherever and whenever the prospect of tactical and strategic

\footnotetext{
${ }^{1}$ I left the Situationist International and its growing burden of empty self-importance in November 1970.
} 
effectiveness is offered. Their sole concern will be to pursue undivided gratification and, inseparably, to kindle the fire of working-class guerrilla warfare - that negative and positive fire which, though it begins in the very heart of the proletariat, is nevertheless the only possible basis for that class's abolition as part of the abolition of class society in its entirety.

The workers may still lack the coherence of their own potential strength, but one thing is certain: once they do achieve that coherence, their victory will be definitive. The recent history of wildcat actions and riots is the writing on the wall which announces the resurgence of workers' councils and the return of Communes. The sudden reappearance of these forms - sure to be met by a repressive counter-attack whose violence will put the repression of intellectual movements in the shade - is likely to surprise only those who cannot discern, beneath the pluralisms of the spectacle's immobility, the unitary progress of the old mole, the proletariat's continuing clandestine struggle for the appropriation of history and the global overthrow of all the conditions of daily life. In the meantime, the necessity of history-for-itself may be perceived in all its cunning in the negative coherence attained by a proletariat disarmed, a sort of concave unanimity which stands as a monumental warning to everything which threatens the radicalism of the working class from within: to intellectualising tendencies, which cause consciousness to regress to the level of book learning and culture; to uncontrolled mediators and their bureaucratic 'opposition'; to the status-lovers, more enamoured of the renewal of roles than of their dissolution in the playful emulation characteristic of the basic guerrilla group; and to all those forces which press for the abandonment of concrete subversion, of the revolutionary conquest of territory, of the unitary, international march towards the end of separations, the end of self-sacrifice, the end of forced labour, the end of hierarchy, and the end of the commodity in its every last manifestation.

The gauntlet thrown down by reification to each person's creativity can no longer be picked up by means of some theoretical "What is to be done?". The proper response lies rather in the practice of the revolutionary act. Anyone who fails to discover in revolution the crucial passion which opens the door to all others can attain but a travesty of real pleasure. The Traité de savoirvivre sought to trace the shortest path from individual subjectivity to its actualisation in historymade-by-all. From the standpoint of the long revolution, it was a mere point of departure - on the road towards communalism and generalised self-management. Similarly, the Traité is merely an outline - albeit an outline of the death sentence which the society of survival pronounces upon itself, and which will one day be executed without appeal by the international of factories, fields and streets.

We have a world of pleasures to win, and nothing to lose but boredom.

October 1972 
The Anarchist Library

Anti-Copyright

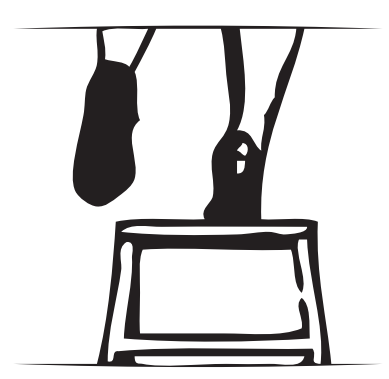

Raoul Vaneigem

The Revolution of Everyday Life

1963-1965

Retrieved on May 14, 2009 from library.nothingness.org

Translated by John Fullerton \& Paul Sieveking. The parts "Author's Preface" and "A Toast to Revolutionary Workers” have been added from D. Nicholson-Smith's translation.

theanarchistlibrary.org 